\title{
2 Intraregional Diversity. Approaching Changes in Political Topographies in South-western Norway through Burials with Brooches, AD 200-1000
}

\begin{abstract}
This chapter addresses socio-political structure and change through the examination of spatial and temporal differences in the deposition of brooches in burial contexts and aspects of burial practices. Diachronic sub-regions within Rogaland and parts of southern Hordaland are inferred, enabling a further address of the trajectories within sub-regions and how they interrelate in ongoing socio-political processes. The paradox of observed concurrent processes of homogenisation and upsurges of local or regional particularities is addressed through the theoretical framework of globalisation. Within the study area, the sub-regions of Jæren and the Outer coast/Karmsund appear most defined throughout the period AD 200-1000. Here, quite different trajectories are observed, indicating a parallel development of different practices and sub-regional identities.
\end{abstract}

\subsection{Introduction}

Throughout the Iron Age, dress accessories included brooches, clasps, and pins that held garments together while simultaneously adding decorative and communicative elements to the dress. While the functional aspects of brooches are persistent, their form and ornamentation vary greatly within the first millennium AD; the typologies of brooches thus constitute a major contribution to the development of Iron Age chronology (Klæsøe 1999:89; Kristoffersen 2000:67; Lillehammer 1996; Røstad 2016a). As such, the brooches deposited in burials provide an exceptional opportunity to address both spatial and temporal variations in burial practices, and furthermore in the social groups that performed those rituals.

Regionality, defined as the spatial dimension of cultural differences (Gammeltoft and Sindbæk 2008:7), is here approached on a microscale, focusing on intra-regional diversity in the selective and context-specific use of a particular part of material culture, namely the brooches. This article draws on basic notions within 'materialityoriented' theory, particularly the co-constitution of people and things where the objects both embody intentionality and mediate social agency, and thereby may both become a material citation of an owner or giver and serve to make claims of certain identity aspects (Back Danielsson 2016; Boivin 2008:26-7; Gosden and Marshall 1999; Hoskins 2006:76-8 with refs.; Jones 2004:330; Klevnäs 2016:467-9). Meaning is accumulated in objects over time and materialised through practice and their societal

Mari Arentz Østmo, Museum of Cultural History, University of Oslo

Ә Open Access. (C) 2020 Mari Arentz Østmo, published by De Gruyter. (c) BY-NC-ND This work is licensed under a Creative Commons Attribution-NonCommercial-NoDerivatives 4.0 International License.

https://doi.org/10.1515/9783110421101-002 
and depositional context (Back Danielsson 2016:520; Gosden and Marshall 1999:172; Joy 2009:544). Common practices or material similarities can thus be understood as important mechanisms of group formation and indicative of shared dispositions and ideals. Funerary rituals in the Iron Age display great diversity, not only in the selection of objects to accompany the deceased, but also in the treatment of bodies and the construction of monuments. The ritual context of funerals provides an arena for negotiation and manipulation of identities, as well as social, cosmological, and political order (Kristoffersen and Østigård 2008; Østigård 2015; Østigård and Goldhahn 2006). Artefact selection and other funerary practices are here understood as part of a symbolic, material, and ritual vocabulary applied by the living relatives (Carver 2011:936). Funerals thus create arenas suited for securing the afterlife of the deceased through a proper ritual, as well as for negotiation and manipulation of social and political positions and relations for the living. The brooch types selected for burials form the primary object of investigation. Burial practice in terms of treatment of the deceased or the construction of monuments serves to complement or contrast the sub-regions suggested through variation in brooch selection.

Beyond identifying such sub-regions, this article seeks to examine how and in what manner the sub-regions relate to socio-political structure and change. Previous works on socio-political elites in western Norway (e.g. Myhre 1987, 1991) have argued for processes of centralisation and fragmentation in the late Roman and Migration periods. Other studies on the formation of political alliances (Glørstad 2012) or communal institutions (Iversen 2018; Storli 2010) have argued for centralisation and emerging kingship in the late Iron Age. With such processes in mind, chronological shifts in inferred sub-regions, particularly those that indicate changes in their extent and increased or decreased similarities between sub-regions, will be compared and contrasted with the chronological changes within elite structures in the 3rd-10th centuries AD.

The analysis is structured both temporally and spatially. First, diachronic subregions are inferred from the study of burial practices and brooch variation. Then, the trajectories of the individual sub-regions are addressed, producing a complex deep-time regional micro-pattern that contributes to the discussion of how subregions are defined and contrasted vis-à-vis each other throughout the 3rd-10th centuries AD. Furthermore, this paper seeks to investigate how the sub-regions interrelate over time and to what degree they relate to ongoing processes of centralisation or local distinction/fragmentation. A detailed chronology of Avaldsnes permits a correlation with the chronological shifts of a socio-political centre within the study area. The most profound contrasts may be observed between Karmsund on the outer coast and Jæren. These landscapes are also marked by other differences, such as the single elite centre of Avaldsnes by the Karmsund strait, versus the numerous and proximate elite centres at Jæren.

The maintained practice of depositing brooches in burials demonstrate that these objects were intensively circulated in this period, and also that they were 
deemed particularly suited for deposition in burial contexts in parts of the study area. The analyses comprise 613 brooches from 541 burials dating to the period AD 200-1000 and located in Rogaland and parts of Sunnhordland; see Fig. 2.1 for a general overview of the distribution and the study area.

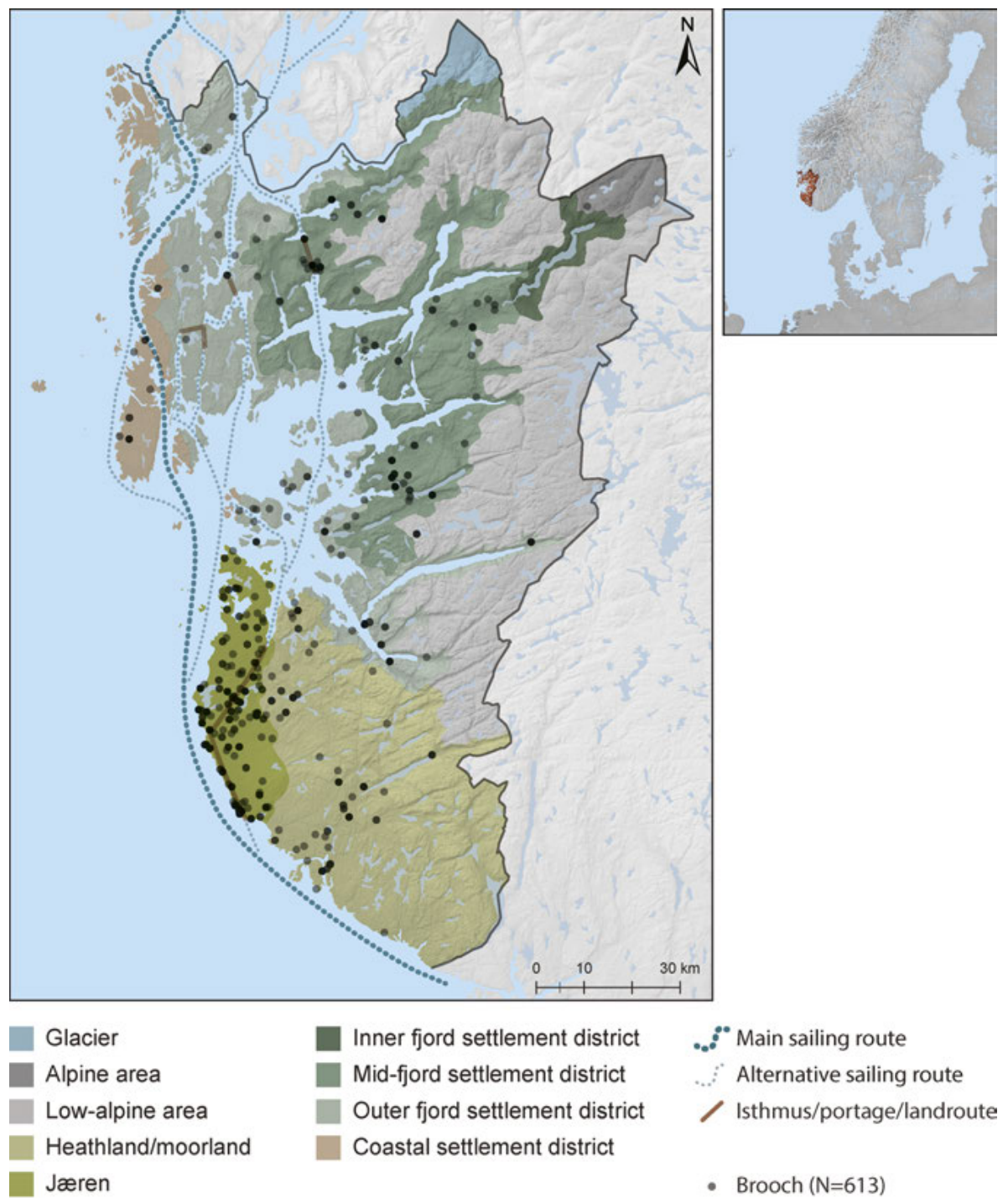

Fig. 2.1: Study area and distribution of 613 brooches dated AD 200-1000 discussed in this article. Due to scale and level of geographical precision, brooches within the same burial overlap; some neighbouring burials may even conceal each other. As the symbols for individual brooches are transparent, such overlaps are identifiable by darker shades. Illustration: M. Østmo, I. T. Bøckman, MCH. 


\subsubsection{Landscape and communication}

While the brooches display temporal and spatial change, the analysis relates to two main spatial constants; namely the main sailing route along the western Norwegian coast, and a defined set of landscape districts within the study area. The sailing route runs through sounds and straits and provides a line of communication sheltered from the rough seas. The sailing route was crucial not only for mobility, but for control over people and trade, made possible by control of strategic places along the route (Skre 2018). Avaldsnes, located where the narrow Karmsund creates a bottleneck on the sailing route, is one such strategic site, and forms a third constant in this analysis. As one of several socio-political centres defined by the presence of imported glass vessels or bronzes, artefacts of gold, or other recognised elite insignia (particularly Kristoffersen et al. 2014; Myhre 1987, 2007; Reiersen 2010, 2017; Ringstad 1992), Avaldsnes is especially suited for a long-term analysis. Here a range of activities and short-term events recorded in archaeological features or written sources display continued socio-political centrality from the 3rd century AD up to the late 14th century. While the site undergoes chronological changes within the study period, the recent excavations have provided a detailed chronology that overlaps with the period in which brooches occur frequently in burials in south-western Norway. An overview of the temporal correlation between the burials with brooches and the contemporary characteristics of Avaldsnes is presented in Tab. 2.1. The oldest burials with brooches included in this study are contemporary with the establishment of Avaldsnes as an elite centre through the princely burial in Flaghaug, Grave 2, the construction of a hall building and boathouse for a ship, and the development of a structured spatial organisation of the farm.

The landscape districts used in the analyses are defined in a report from the Institute for Norwegian Land and Forest Mapping, now the Norwegian Institute of Bio-economy Research (NIBIO) (Puschmann 2005). Vectorised GIS files of hierarchically levelled landscape districts have been made publicly accessible by NIBIO. In a hierarchical system for landscape classification, definitions of landscape districts and corresponding sub-districts are based on six components: major terrain forms, minor terrain forms, water and watercourses, vegetation, agricultural land, and technical installations. Particularly the first two components are considered in distinguishing landscape regions; borders drawn where characteristic terrain changes form (Puschmann 2005:2-3). A rough estimate from Avaldsnes on the outer coast indicates that the sea level at AD 200 and 800 would be 2.4 and 1.6 meters above present sea level respectively (Bauer 2018:185-96 with further references). With regard to vegetation, the transformation of the coastal landscape in terms of deforestation and the development of coastal heaths was completed within the study area by 200 BC (Prøsch-Danielsen and Simonsen 2000:41). While there are differences in shorelines and vegetation due to land rise and the effect of historic agriculture, these differences are not considered fundamental in terms of conditions for connectivity or human interrelations. 
Tab. 2.1: Chronological phases and their respective characteristic traits in the analysed burials with brooches and at Avaldsnes. Avaldnes phases follow Østmo and Bauer (2018b).

\begin{tabular}{|c|c|c|c|c|}
\hline Chronology & $\begin{array}{l}\text { Characterstic } \\
\text { brooches in } \\
\text { analysed } \\
\text { burials }\end{array}$ & Main trends in burials & $\begin{array}{l}\text { Avaldsnes } \\
\text { phases }\end{array}$ & $\begin{array}{l}\text { Characteristic aspects of } \\
\text { the Avaldsnes settlement }\end{array}$ \\
\hline $\begin{array}{l}\text { C1b-C2 } \\
\text { AD 210/220- } \\
310 / 320\end{array}$ & $\begin{array}{l}\text { R230-9, } \\
\text { Almgren VII ser. } \\
2 \text { and } 3 \text { (bronze } \\
\text { or silver), rosett } \\
\text { fibula }\end{array}$ & $\begin{array}{l}\text { Burials w/broches are } \\
\text { found in several } \\
\text { landscape regions, in } \\
\text { central areas or } \\
\text { strategic areas along } \\
\text { routes of } \\
\text { communication. } \\
\text { The earliest inhumation } \\
\text { burial with brooches in } \\
\text { an oblong cairn } \\
\text { foreshadows the large } \\
\text { beach cemeteries of the } \\
\text { following periods. } \\
\text { Remaining monuments } \\
\text { are mainly round } \\
\text { mounds. }\end{array}$ & \multirow{3}{*}{ AD 200-600 } & \multirow{3}{*}{$\begin{array}{l}\text { Princely burials and } \\
\text { mortuary monuments } \\
\text { predominantly dating to } \\
\text { the 3rd Century are } \\
\text { constructed, reuseed and } \\
\text { manipulated centrally at } \\
\text { Avaldsnes and adjacent } \\
\text { farms. Significant burials: } \\
\text { The Flaghaug grave } 2 \\
\text { (C1b-C2) with roman } \\
\text { vessels and weaponry, } \\
\text { gold neck ring, gold } \\
\text { finger rings etc, Flaghaug } \\
\text { grave } 4 \text { (C1b-C2) with } \\
\text { Hemmooor bucket and } \\
\text { gold rings, raised stones } \\
\text { monument (likely 3rd } \\
\text { century), Flaghaug grave } \\
3 \text { (C3) westland kettle, } \\
\text { stray finds from disturbed } \\
\text { graves: a gold serpent } \\
\text { head ring and pendant } \\
\text { (C1b-C2) and set of spear } \\
\text { and lance (Migration } \\
\text { period) }\end{array}$} \\
\hline $\begin{array}{l}\text { C3 } \\
\text { AD } 310 / 320-400\end{array}$ & $\begin{array}{l}\text { Nydam fibula, } \\
\text { bugelknopf } \\
\text { fibula, equal- } \\
\text { armed brooches } \\
\text { w/triangular } \\
\text { ends, early } \\
\text { R243 and } \\
\text { related 'simple } \\
\text { bow-fibulas' }\end{array}$ & $\begin{array}{l}\text { Sub-region Jæren } \\
\text { characterised by } \\
\text { inhumation, oblong/ } \\
\text { oval monuments and } \\
\text { diversity of brooch } \\
\text { corpus. } \\
\text { Sub-region } \\
\text { Heathland/Highland } \\
\text { distinguished by } \\
\text { practicing cremation }\end{array}$ & & \\
\hline $\begin{array}{l}\text { D1 } \\
\text { AD 400-475 }\end{array}$ & $\begin{array}{l}\text { Cruciform } \\
\text { brooches, spiral } \\
\text { clasps, relief } \\
\text { brooches } \\
\text { (Nissen Meyer } \\
\text { stadium 2) }\end{array}$ & $\begin{array}{l}\text { Cruciform brooches in } \\
\text { all landscapes exept } \\
\text { the Outer coast. Similar } \\
\text { tendencies for relief } \\
\text { brooches. Both } \\
\text { widespread and local } \\
\text { distributions particular } \\
\text { to some sub-regions. }\end{array}$ & & \\
\hline
\end{tabular}


Tab. 2.1 (continued)

\begin{tabular}{|c|c|c|c|c|}
\hline Chronology & $\begin{array}{l}\text { Characterstic } \\
\text { brooches in } \\
\text { analysed } \\
\text { burials }\end{array}$ & Main trends in burials & $\begin{array}{l}\text { Avaldsnes } \\
\text { phases }\end{array}$ & $\begin{array}{l}\text { Characteristic aspects of } \\
\text { the Avaldsnes settlement }\end{array}$ \\
\hline $\begin{array}{l}\text { D1 } \\
\text { AD 400-475 }\end{array}$ & & $\begin{array}{l}\text { Jæren distinguished by } \\
\text { high number, wide } \\
\text { diversity, several } \\
\text { identical brooches in the } \\
\text { same burial and high } \\
\text { frequency of inhumation } \\
\text { and oblong/oval } \\
\text { monuments }\end{array}$ & & $\begin{array}{l}\text { A hall building } \\
\text { (AD 236-381) facing the } \\
\text { strait, longhouse } \\
\text { (AD 349-600) with } \\
\text { several phases of } \\
\text { reparations and } \\
\text { reconstructions }\end{array}$ \\
\hline $\begin{array}{l}\text { D2a } \\
\text { AD 475-525 }\end{array}$ & $\begin{array}{l}\text { Cruciform } \\
\text { brooches, } \\
\text { button clasps, } \\
\text { relief brooches } \\
\text { (Nissen Meyer } \\
\text { stadium 3-4) }\end{array}$ & $\begin{array}{l}\text { Smaller subregions in the } \\
\text { mid and inner fjord } \\
\text { districts }\end{array}$ & & $\begin{array}{l}\text { Boathouse for a ship, } \\
\text { initial construction dated } \\
\text { AD 258-381 and a } \\
\text { secondary phase } \\
\text { approximately } \\
\text { AD 426-552 }\end{array}$ \\
\hline $\begin{array}{l}\text { D2b } \\
\text { AD 525-550/560 }\end{array}$ & $\begin{array}{l}\text { Relief brooches } \\
\text { (Nissen Meyer } \\
\text { stadium 5-6), } \\
\text { relief brooches } \\
\text { (Sjøvold B-1), } \\
\text { equal-armed } \\
\text { brooches } \\
\text { without } \\
\text { endplates }\end{array}$ & $\begin{array}{l}\text { Spiral clasps (D1) } \\
\text { oriented to inner } \\
\text { districts, button clasps } \\
\text { (D2) oriented towards } \\
\text { the outer sailing routes }\end{array}$ & & $\begin{array}{l}\text { Large continuous fields } \\
\text { for cultivation, truncated } \\
\text { by cooking pits west of } \\
\text { the dwellings and } \\
\text { farmyard through the } \\
\text { whole period. }\end{array}$ \\
\hline \multirow[t]{2}{*}{$\begin{array}{l}\text { Merovingian } \\
A D 550 / 560- \\
775 / 800\end{array}$} & \multirow[b]{2}{*}{$\begin{array}{l}\text { equalarmed } \\
\text { brooches, disc- } \\
\text { on-bow- } \\
\text { brooches, bird- } \\
\text { fibulas, thin- } \\
\text { shelled oval } \\
\text { brooches }\end{array}$} & $\begin{array}{l}\text { Few burials forming a } \\
\text { break with the previous } \\
\text { centuries }\end{array}$ & & \\
\hline & & $\begin{array}{l}\text { Disc-on-bow brooches at } \\
\text { Jæren } \\
\text { New: burials with } \\
\text { brooches at Ferkingstad, } \\
\text { Karmøy } \\
\text { Conical brooches at } \\
\text { Jæren and the Outer } \\
\text { fjord districts }\end{array}$ & \multirow[t]{2}{*}{ AD 600-900 } & \multirow[t]{2}{*}{$\begin{array}{l}\text { Palisade constructed in } \\
\text { the } 7 \text { th century, } \\
\text { delimiting and protecting } \\
\text { a food-storage area. } \\
\text { Implies continued } \\
\text { settlement }\end{array}$} \\
\hline \multirow[t]{2}{*}{$\begin{array}{l}\text { Viking Age } \\
A D 775-800 / \\
1000\end{array}$} & \multirow{2}{*}{$\begin{array}{l}\text { Oval brooches, } \\
\text { penannular } \\
\text { brooches, equal } \\
\text { armed } \\
\text { brooches, trefoil } \\
\text { brooches, } \\
\text { brooches of } \\
\text { transformed } \\
\text { imported } \\
\text { fittings - mainly } \\
\text { insular }\end{array}$} & \multirow[b]{2}{*}{$\begin{array}{l}\text { Inhumation dominant in } \\
\text { all areas, except } \\
\text { heathland region, also } \\
\text { marked by slightly later } \\
\text { brooches }\end{array}$} & & \\
\hline & & & AD 900-1250 & $\begin{array}{l}\text { Fragmented remains of a } \\
\text { building of unknown size } \\
\text { and function, with } \\
\text { prominent location } \\
\text { between monuments, } \\
\text { oriented towards the } \\
\text { strait, dated } \\
\text { AD 901-1023 }\end{array}$ \\
\hline
\end{tabular}


Tab. 2.1 (continued)

\begin{tabular}{|c|c|c|c|c|}
\hline Chronology & $\begin{array}{l}\text { Characterstic } \\
\text { brooches in } \\
\text { analysed } \\
\text { burials }\end{array}$ & Main trends in burials & $\begin{array}{l}\text { Avaldsnes } \\
\text { phases }\end{array}$ & $\begin{array}{l}\text { Characteristic aspects of } \\
\text { the Avaldsnes settlement }\end{array}$ \\
\hline $\begin{array}{l}\text { Viking Age } \\
\text { AD 775/800-1000 }\end{array}$ & & $\begin{array}{l}\text { South Boknafjord basin } \\
\text { integrated with Jæren in } \\
\text { a new sub-region } \\
\text { defined by similar oval } \\
\text { brooches, insular } \\
\text { brooches, equal armed } \\
\text { brooches and burial } \\
\text { practices } \\
\text { The penannular } \\
\text { brooches indicate } \\
\text { political alliance } \\
\text { centered around } \\
\text { Avaldsnes, placed at } \\
\text { strategic places along the } \\
\text { routes of communication } \\
\text { at Karmøy, the } \\
\text { fjorddistricts and Jæren } \\
\text { (Glørstad 2010, 2012) }\end{array}$ & & $\begin{array}{l}\text { Stable cultivation activity. } \\
\text { Continued use of food } \\
\text { storage, with a slight } \\
\text { intensification around the } \\
\text { transition from the } 9 \text { th to } \\
\text { 10th century, six features } \\
\text { with cerals are dated AD } \\
872-986 . \text { One corndrying } \\
\text { kiln dated AD 1033-1152 }\end{array}$ \\
\hline
\end{tabular}

The landscape districts are not assumed to correspond to the spatial dimensions of social aggregates in the Iron Age, as the districts are defined and static, while the social sub-regions are expected to vary and change depending on their particular historical and socio-political contexts. Rather, the landscape districts are used both as a means of visualising landscape conditions in map illustrations, and as a way of approaching similarities or variations of practice particular to different parts of the study area. The definitions based on terrain, variations in sediments and watercourses which condition settlement, agriculture, and communication with communities near or far, is what makes them relevant also for an Iron Age context, despite changes in sea level or vegetation. The recurrent spatial overlap between burials with brooches and some of these landscape districts is the strongest indication for their relevance. Likely these alignments relate to the preconditions the landscapes provide in terms of connectivity and social interaction, and thus for the circulation of material culture. A detailed overview of the landscape districts and their characteristics may be found in Tab. 2.2, while the spatial dimension of these districts may be found in Fig. 2.2.

\subsubsection{A conceptual framework}

From the perspective of the formation of early medieval kingdoms in England, Christopher Scull (2001:122) has stated that models for these centralisation processes 
Tab. 2.2: Overview of the landscape districts and their characteristics, after Puschmann (2005)/ NIBIO.

\begin{tabular}{|c|c|c|}
\hline $\begin{array}{l}\text { Landscape } \\
\text { district }\end{array}$ & Characteristics & Landscape sub-districts \\
\hline Low Alpine & $\begin{array}{l}\text { High, barren landscapes. Wide, open moores, } \\
\text { heaths or low alpine valleys }\end{array}$ & Dyraheio, Saudafjella \\
\hline $\begin{array}{l}\text { High } \\
\text { Alpine }\end{array}$ & $\begin{array}{l}\text { High, barren landscapes. Peaks, wide vistas } \\
\text { over peaks, heaths and valleys, glaciers }\end{array}$ & glaciers: Folgefonni, Nupsfonn \\
\hline $\begin{array}{l}\text { Heathland/ } \\
\text { Moorland }\end{array}$ & $\begin{array}{l}\text { Least fertile lowland. Many valleys of which } \\
\text { some are green and lush, pasture, heather, } \\
\text { rocky hillocks, steep exposed coastline }\end{array}$ & $\begin{array}{l}\text { Dalane, Bjerkreim/Sirdalsvatnet, } \\
\text { Jæren fjellbygd }\end{array}$ \\
\hline Jæren & $\begin{array}{l}\text { Coast with sand/pebble beaches, flat } \\
\text { cultivated, very fertile lowland. Wide vistas, } \\
\text { exposed coastline, no archipelago }\end{array}$ & Låg Jæren, Høg Jæren \\
\hline $\begin{array}{l}\text { Outer } \\
\text { coast }\end{array}$ & $\begin{array}{l}\text { Strandflat. Sea surfaces broken by islands, } \\
\text { skerries, bare rock, straits and small fjords- } \\
\text { creating landscape rooms of various forms/ } \\
\text { sizes. Sea varies between still/frothing/big } \\
\text { waves, coastal heathland/pasture, thin } \\
\text { sediments, limited cultivation, peat bogs }\end{array}$ & Øygarden/Karmøy \\
\hline $\begin{array}{l}\text { Outer } \\
\text { fjords }\end{array}$ & $\begin{array}{l}\text { Elevated part of the strandflat: fjords and } \\
\text { hillsides, lusher/greener compared to Outer } \\
\text { coast }\end{array}$ & $\begin{array}{l}\text { Lysefjorden, Jøsenfjorden, } \\
\text { Etnefjorden, Etnefjorden/ } \\
\text { Vindafjorden, Åkrafjorden }\end{array}$ \\
\hline Mid fjords & $\begin{array}{l}\text { Narrow fjords and valleys, moraines, short/ } \\
\text { steep waterways, waterfalls }\end{array}$ & $\begin{array}{l}\text { Ryfylke islands, Sveio/Haugalandet, } \\
\text { Halsnøy, Bjørnafjorden }\end{array}$ \\
\hline $\begin{array}{l}\text { Inner } \\
\text { fjords }\end{array}$ & $\begin{array}{l}\text { Grand fjordlandscape, high contrasts } \\
\text { mountains-fjords, narrow lakes, valleys }\end{array}$ & Røldals/Suldalsvatnet \\
\hline
\end{tabular}

remain general as there is no archaeological evidence that permits identification of such socio-political units, despite numerous documentary sources. Traditionally, archaeological regions have been identified either retrogressively from younger historical regions, or by analysing material culture in terms of similarities and differences (Helgesson 2008:50). In addition, the structuring capacity of the natural borders for the location and character of settlements, as well lines of communication, have been taken into account in several works, while a wider spectrum of cultural expressions have been studied within a given landscape implicitly understood as a region (Callmer 1991:262; Hyenstrand 1974:13; Tesch 1992).

In Scandinavian research, several authors have addressed a wide range of regionalities. Chronologically, these articulations span from the Roman Period to the Viking Age, and are manifested within ritual systems, burial practices, architecture 


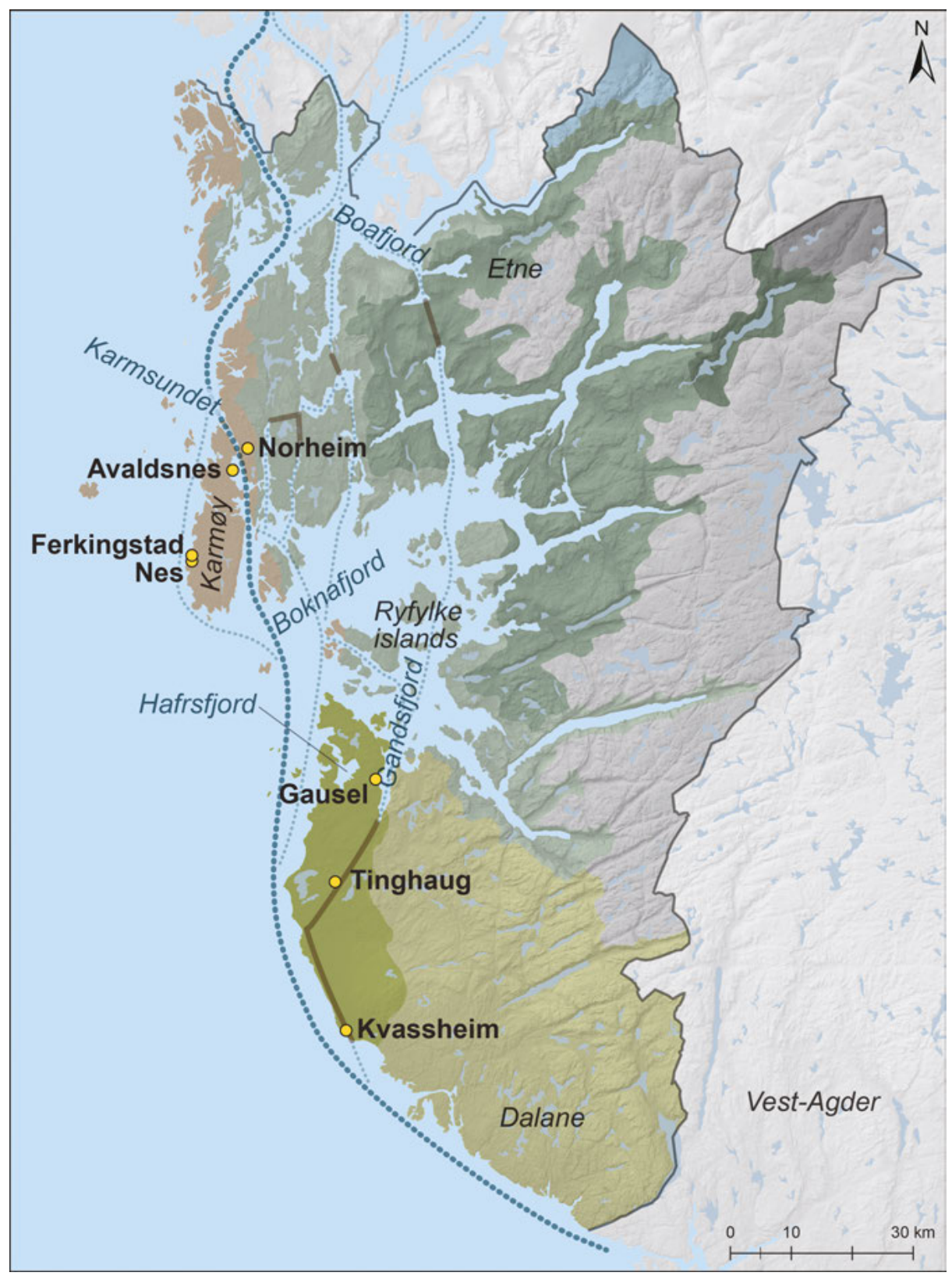

Fig. 2.2: The delimitation of landscape districts as defined by Puschmann (2005)/NIBIO. Overview of place names mentioned in the text. Illustration: M. Østmo, I. T. Bøckman, MCH. 
and settlement organisation, technology, and the use and distribution of material culture (Callmer 1991; Engevik 2010; Fabech and Ringtved 1991; Gammeltoft et al. 2008; Gjerpe 2016; Holst 2014; Petersson et al. 2008; Røstad 2015; Sindbæk 2008b; Svanberg 2003). Helgesson (2008:49) encourages consideration of both if and how prehistoric regions may be identified, and what they contribute to our understanding of human networks and strategies. According to Callmer (et al. 2017:3), material similarities presuppose intense communication within groups of people and contribute to the formation of cultural identities. Perceiving identity as something unfixed and constantly becoming, the circulation and use of material culture should be understood as recurring moments in ongoing processes of group formations, as argued by Gammeltoft and Sindbæk (2008:9). Scull's concern regarding the lack of archaeological support for regional identities reflecting kingdoms evidenced in documentary sources could imply that the networks and arenas of communication through which material culture was circulated were played out on a different social or geographical scale than that of a kingdom. Such differences in network scales have been argued for Viking Age Denmark (Sindbæk 2008b). Through formal network analyses of settlement sites with a selection of non-luxury artefacts Sindbæk (2010:268, 84) finds that the contact between regions took place through a small selection of sites, that wide distributions likely involve arenas for communication simultaneously involving larger fractions of the population. Herein lies also a response to Helgesson's considerations. Material similarity entails intense communication within a group, in itself indicative of networks. Examination of likely arenas for communication and distribution offers one approach to the underlying human strategies, as well as the mechanism that held groups together or set them apart from others, and the interrelation between social interaction and political structures.

According to Knappett (2017:35), it is when networks shift from networks of exchange to networks of affiliation that the circulation of materials may create social effects. Such mechanisms may be observed in Scandinavia in the late Roman and Migration periods. At that time, the initial circulation of imported artefacts such as bronze or glass vessels and Roman weapons was the prelude to an import of military techniques and hierarchical structure, affecting the local power structures (Sindbæk 2017:554-5). Chiefly or princely paraphernalia in burials such as the Flaghaug burial at Avaldsnes, constitute a superregional elite ideology involving artefacts of distant origins. The far-reaching connections implied by such objects may have contributed as much to the value of an object as its material components (Fontijn and Vaart-Verschaaf 2017:525). Such artefacts reference a super-regional imagery in contrast to local practice - what Fontijn and Vaart-Verschaaf (2017:527) term as elitist mortuary identities, which make up cornerstones in models of sociopolitical centres (Myhre 1987, 1991; Reiersen 2017:148-9).

Connectivity is central within the conceptual framework of globalisation. According to Hodos, globalisation is characterised by "processes of increasing connectivities that unfold and manifest as social awareness of those connectivities" 
(Hodos 2017:4). Globalisation thus not only leads to shared practices, but also increases awareness and distinction of (cultural) difference, manifesting in local identities. Identities and practices are both similar and different, or a particularisation of the 'universal' (Witcher 2017:645). Such concepts should not be understood to stand in opposition to other models for socio-political change, such as peerpolity competition or centre-periphery dynamics. In fact, structured competition amongst local elites contributed to the spreading of Roman goods and ideology into Germanic areas, where they were combined with locally produced elite insignia, such as rosette fibulas or serpent head rings of gold, and used in the construction of political hierarchies (Hedeager 1992a:92; Witcher 2017:647-8). Some of the differences between these approaches lie in their different implicit presumptions, where centre-periphery implies a directionality from (active) centres to (passive) peripheries. In addition, the definition of what is central and what is peripheral depends on point of view - whether seen from Rome, or from Jutland or Jæren. Globalisation as a framework offers an alternative to top-down, centre-out approaches, instead enabling analyses that simultaneously combine the local and the global. Amongst other benefits is the implication of a process that unfolds over time, allowing a deep-time perspective on human connections and their synergies on different social or spatial scales (Feinman 2017:48-9). This article will draw on other sources to connectivity, such as non-local imports or the presence of boathouses, assuming their relevance for mobility by sea in order to interpret the patterns of spatial similarity or diversity.

As background to the review of research history of socio-political structure, centres, and groups, a few remarks are called for with regard to the selection of brooches as the crux of this analysis. Brooches and other jewellery are amongst the artefacts that traditionally have been associated with women and seen as indicative of female burials (Shetelig 1912:110). The inferring of social gender roles from artefacts is in itself a voluminous and complex discourse that lies beyond the scope of this article. Here, it is not gender per se that is the object of examination, but rather the structured use of brooches in processes of group formation. Objects with an established association with female gender have been imbued with other symbolic meanings or references as well. The gender role of 'lady of the house' has become a firmly established reference for burials containing pairs of brooches combined with keys and textile related tools (Kristoffersen 2000, 2004a, 2004b; Sundqvist 2014). The recurrent use of such stereotyped gender roles has been criticised, amongst other by Berg (2015:137) who argues that keys, rather than referencing an image of the 'housewife' symbolises ownership and access regardless of gender. Similarly, the household equipment and commodities in the Oseberg ship burial may have contributed to downplaying the interred woman's/women's political position in favour of a social position connected to the household sphere, whereby a woman's rank was determined by the rank of her male relatives. Alternatively, these objects may, according to Pedersen (2017:119-20), be interpreted as a representation of the court of a political 
ruler and as a demonstration of wealth and power. Burials traditionally gendered as female are no less likely than male burials to be politically significant. Certain gendered roles or ideals may become politicised in specific historical contexts. Along these lines, Glørstad (2010:206) has argued that high-quality cloaks and penannular brooches circulated among sections of the political elite in the Viking Age, thus becoming an expression of an aristocratic masculine ideal and a political statement. Repeated and structured use of dress accessories, particularly in ritualised contexts, contributes to objects becoming politicised and underlines the social roles or networks they symbolise (Glørstad 2010:170-1). Following Sindbæk (2010:284), such practices become more integrated and widespread within a network after reaching a threshold of use by sufficiently influential and numerous persons. The effect of such objects in burial contexts is their contribution to staging public personas and identities and signalling group membership (Gosden 2005). Other identity aspects, such as gender, may be intertwined with group identities, and are here addressed only in their politicised form.

Fredrik Barth's (1969) seminal work on ethnic groups and boundaries brought focus to the active production and transformation of ethnic identity through interaction. His approach underlines that any particular practices or aspects of material culture may become ethnic markers depending on their historical and cultural context. In this manner, ethnicity - or identity for that matter - becomes instrumental. Curta (2007:167) suggests an understanding of ethnicity as both instrumental and primordial. His understanding draws on the practice-theoretical approach of Bourdieu (1977), in which the embodied social structures and disposition of the habitus socialise people into a cultural understanding of their ethnicity from birth, making it close to innate (Curta 2007:166-7). Material culture does not simply reflect ethnicity, but is both the cause and effect of this social process of identity negotiation (Curta 2007: 169-70). Repeated ritual practice, as seen in burial contexts, becomes both a medium for and result of aspects of identity.

\subsubsection{Material and methods}

The 613 brooches from 541 burials included in this study have been collected based on the inventory databases of the regional museums at the universities of Oslo, Bergen, and Stavanger. ${ }^{1}$ They have been classified based on type descriptions in the inventories and overviews in published works (in particular Kristoffersen 2000; Lillehammer 1996; Meyer 1934; Petersen 1928; Reichstein 1975; Shetelig 1910) and

1 A visual examination of all brooches would be far more time consuming and might have called for alternative parameters to delimit the study, as it was conducted within the framework of a three-year PhD project. A deep-time study was permitted by relying on published secondary sources, inventory descriptions, and photos. 
unpublished works (Glørstad 2012; Jensen 1998; Røstad 2016a). The type descriptions have been synchronised, as it varies whether museum inventories refer to published overviews such as Shetelig (1906, 1910, 1912), Rygh (1885), Petersen (1928), or others. The brooches are classified in terms of type or subtype, in some cases groups of brooches, such as the 'simple bow brooches' signifying brooches of type R243 or closely related forms, in reference to Rygh (1885). Aspects of mortuary practices were recorded whenever possible, depending on the quality of the accompanying documentation when they were registered in the museums' collections, supplied by descriptions of monuments and finds in records such as Helliesen (1901) and Shetelig (1912). The aspects treated here include treatment of the corpse, monument form, and reuse of monuments. In all following statistical and spatial analyses, identical brooches present within the same burial are recorded as a single instance of a type. Frequencies were calculated in IBM SPSS and grouped in accordance with landscape regions as defined by Puschmann (2005).

The analyses in this article target spatial and temporal variations and consider the nature of their distribution. When inferring societal structures from spatial distribution of material culture, the combination of several sources is preferable (Helgesson 2008:53, with refs). This analysis is based on the correlation of different brooch types and selected aspects of mortuary practices. A full understanding of these practices and the significance of their internal variation deserves a fuller contextual analysis. In this article it must suffice to highlight the covariation of several practices and suggest tentative conclusions regarding their spatial variation. The spatial distribution of other material remains, such as burials with prestigious objects, courtyard sites, or boat houses are included to contrast or support the regional patterns in burials as relevant. A correlation with the chronological phases of Avaldsnes is presented in Tab. 2.1 and addressed in the diachronic presentation and following discussions. Helgesson (2008:55-6) lists several methodological considerations for inferring societal structures from spatial distributions of relevance for the following account and discussion:

1. Consideration of alternative societal models.

2. Attentiveness to lacunae or anomalies in the distribution, and their potential significance.

3. Consideration of the nature of underlying structures or networks: hierarchical, regional, or communal?

4. Considerations of predispositions for connectivity provided by the natural terrain.

5. The nature of peripheries: do they correspond with natural barriers?

6. Attentiveness to the time-depth of the spatial structures, in order to consider their relationship to long-term social structures or short-term events.

The discussion draws on several models presented in previous research on regionality and socio-political structure (in particular Hedeager 1992b; Helgesson 2003, 
2008; Holst 2014; Ringtved 1988; Sindbæk 2008a, 2008b). It should be noted that regional differences observed in previous studies are not clear-cut; there are also interregional similarities. This reality limits the utility of approaches that focus on borders. Scull (2001:123-4), for example, is pessimistic and argues that while political affiliation is likely to have affected burial practices, it is hard to grasp which identities or networks cause regional variations. Before moving on to the presentation of the analyses, it is important to revisit relevant research on socio-political structures in Germanic societies in general and in southwest Norway in particular, as well as research on brooches and ornamentation as a means of creating group or network identities. This will serve to situate the present study in terms of how it correlates with existing knowledge and how it strives to contribute with new understanding.

\subsubsection{Centres and socio-political structure as point of departure}

Early research on the socio-political structure of Germanic societies in Scandinavia and in continental Europe relied heavily on written sources on Germanic tribes, such as the works of Caesar, Tacitus, or Procopius (Kristoffersen 2000; Näsman 1991:322-3). From the 1980s-90s onwards, documentary sources have been paired with anthropological models or post-processual theories, bringing to bear new themes of research, such as symbolic and ideological aspects of burials, ritualization, and the transformation of tribal communities (Hedeager 1992b; Myhre 1987, 1991; Opedal 1998). A prime example of this is Hedeager's research (1992a, 1992b) on the transition from tribal society to early state formation in Denmark, formulating a model in which elites are established and consolidated through ritualised use of prestigious objects in lavish burials. Once the elites are well established, these burial practices are discontinued in the centres while persisting in the peripheries where power is still unstable (Hedeager 1992b:142-5). The spatially structured distribution of prestigious objects with peripheral clusters and 'empty' centres known from documentary sources has been interpreted as the result of similar mechanisms in processes of power formation in northern Gaul in the late Roman Period (Nicolay 2014:330-2).

Variety of forms notwithstanding, relations between lord and retinue are argued to be the common underlying structure of Germanic societies (Nicolay 2014: 3-4). In his seminal work on gift exchange, Mauss (2002 [1924]) argues that a gift is not mere representation, but a personification or extension of the giver; thus, gift exchange forges deeply personal bonds and creates demands of reciprocity. In Graeber's view (2010:11-12), hierarchical transactions are the opposite of reciprocity, albeit camouflaged as such by the suggestion of an equal exchange; peasants providing production surplus in exchange for the lord's protection. A king's power depends on his ability to secure his retinue and alliances via the giving of 
gifts. Steuer's (1989) model of Personenverbandstaat has the same underlying principle: the king's power is not territorial, but built on political alliances and manifested through the giving of exclusive gifts. This model has greatly influenced research on Scandinavian Iron Age elites, centres, and socio-political structures, whether pertaining to weapon distribution, princely burials, or distribution of elite insignia (Jørgensen 1991; Lund-Hansen 2001; Magnus 2002; Myhre 1991; Opedal 2010; Stylegar 2008). Of particular relevance are works that identify political centres within the present area of study, such as Myhre $(1985,1987)$ and Ringstad (1992); their methods and conclusions recently have been reviewed and expanded by Reiersen (2017). Anglo-Saxon kingdoms have also provided a relevant historical model for socio-political structures and change in Scandinavia; for example, Callmer's study (1991:272) arguing that social aggregates in Scandinavia were slightly more territorial than those of Frankish society, while also displaying a variation in size, socio-political levels, and forms of overlordship. For the Viking Age, saga literature and medieval historical sources on ownership and taxation have also been used to identify centres (Bjørkvik 1999; Iversen 2008). These studies have increasingly focused on polycentric models for early estates and their dependant farms (Reiersen 2009, 2017:81-2 with refs; Skre 1998; Stylegar 2001:60-4). Such estates have been argued to form the core in the processes of state formation (Iversen 2008). Skre's (2018) interpretation of Avaldsnes as a manor for sea kings runs along similar lines, bringing historical and linguistic sources into the discussion.

An alternative approach to socio-political structures has been provided by research on material culture's role in negotiating identities. Kristoffersen's (2000) analyses of the use of ornamentation of high-quality dress accessories as a means of creating an 'elite identity' is a major contribution to this field of research. The Tinghaug complex with Krosshaug and other elite burials is suggested as a centre of major importance, associated with the development of particular sub-types of relief brooches (Kristoffersen 2000:145-7, 205-7). The distribution of such brooches outside Jæren, or even Rogaland, is taken as an indication of the extent of Tinghaug's political connections. It should be noted that with a reference to the medieval administrative border created by the Boknafjord, Kristoffersen (2000:179) raises the possibility that this division may have roots in Iron Age realities, but does not investigate this further. With the exception of the votive deposit of a relief brooch on Karmøy, such objects are absent on the outer coast in general and around Karmsund in particular. Thus, this area does not receive attention in Kristoffersen's political interpretation.

The use of brooches in the negotiation of identities constitutes the main focus in Røstad's (2016a) analysis of jewellery in Scandinavia in the 5th-7th centuries AD. Applying a correlated chronology for cruciform brooches, clasps, relief brooches, and conical brooches, she maps their distribution and demonstrates superregional and regional patterns. Some brooch sub-types were common for all of Scandinavia, such as the cruciform brooches type Mundheim, while others were regional types specific to a smaller area, such as the relief brooches of type Rogalandsgruppen 
(Røstad 2016a:120-1, 210-15). Furthermore, she argues that brooches were involved in identity negotiations on different scales and levels, addressing ethnic and other identities. By comparison with Migration Period political units, she concludes that there are some correlations between assumed political structures and the regional identities indicated by brooches - at least in the late 5th and early 6th centuries (Røstad 2015, 2016a:372-6).

By situating the present study among these works, the following analysis strives to provide nuance to the aims accounted for in the introduction. Recent decades have seen an increased focus on ritual or cultural regionality and diversity (Callmer et al. 2017; Svanberg 2003). The concurrent contrast of regional particularities and the many similarities in practices, material culture, and language across regions and vast distances may be ascribed to mechanisms of high and increased connectivity leading to 'similarly different' practices, materialities, or identities (Witcher 2017).

Previous research on socio-political centres or distribution of material culture have resulted in the delineation of several distinct regions along the western coast of Norway. In this article the focus shifts to a smaller scale, addressing intraregional diversity within the regions suggested by previous research. Scale and scope are of course interrelated; distribution maps that serve to display the relative density of any given material object within Scandinavia or Norway inadvertently may contribute to camouflaging regional or sub-regional landscapes. On the contrary, research on elite networks and socio-political centres has shown a great variety of centres across the study area. The choice of scale is essential, not only because it shifts from an inter-regional to intra-regional approach, but also because it allows a novel perspective on the dynamics between socio-political centres and the surrounding landscapes.

\subsection{Sub-regionality - a diachronic perspective}

This section provides a diachronic presentation of the burials with brooches and accounts for the distribution of brooch types in the landscapes as well as mortuary monument form, treatment of the deceased body, and aspects of reuse of mortuary monuments. An overall interpretation of each chronological phase follows the descriptive account, outlining the sub-regions of that period.

\subsubsection{Roman Iron Age, phase C1b-C2 c. 210/220-310/320}

At the very beginning of this period, in the 3rd century, there are only a few brooches within the study area (Fig. 2.3). Following Kristoffersen and Magnus (2010:64), Roman period brooches include R230-239 (type specimen depicted in Rygh 1885), but 


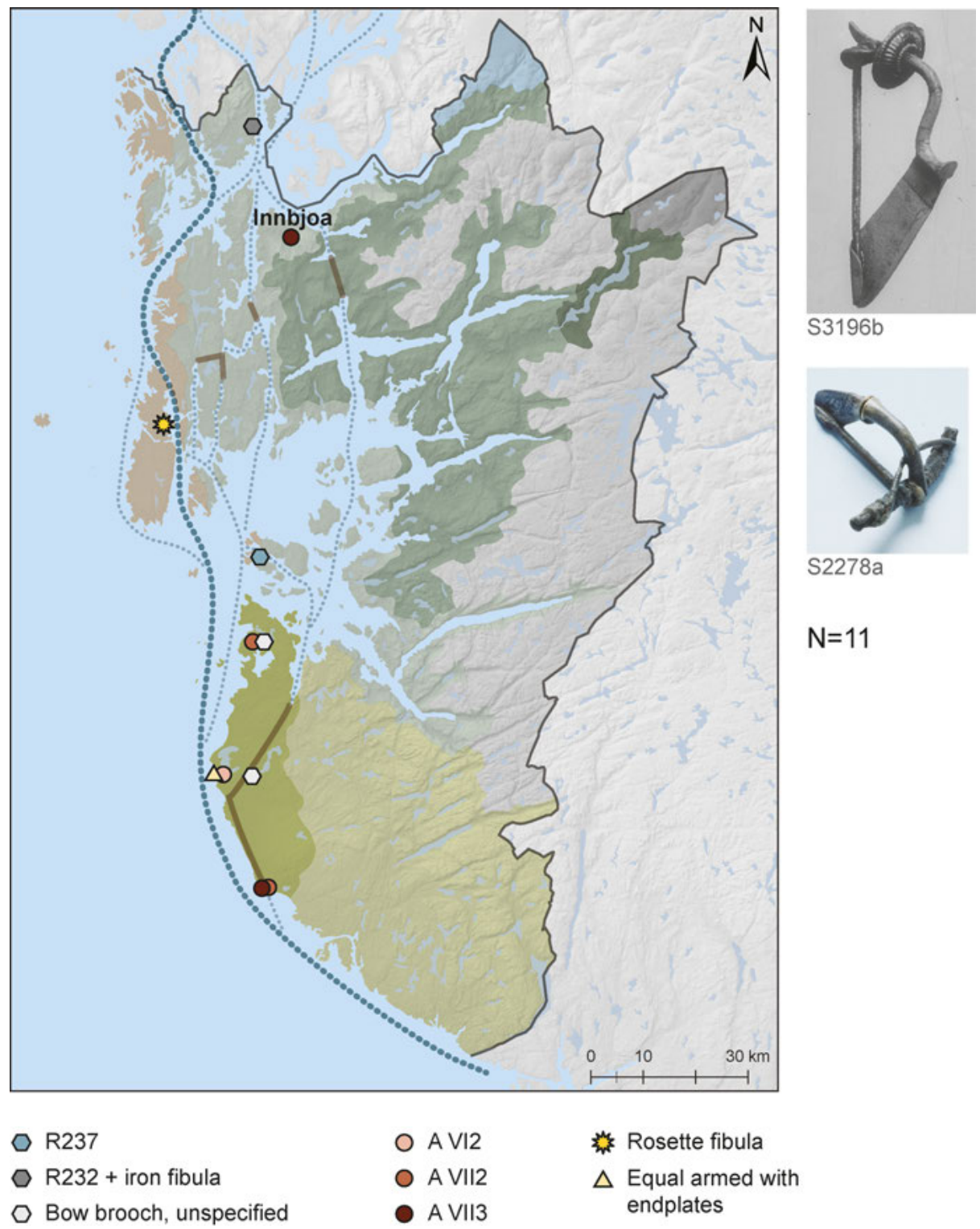

Fig. 2.3: Distribution of $\mathrm{C} 1 \mathrm{~b}-\mathrm{C} 2$ brooches sorted by type. Illustrative examples: rosette fibula S3196, AVII.2 S2278. Landscape districts after Puschmann (2005)/NIBIO. Illustration: M. Østmo, I. T. Bøckman, MCH.

as some of these also date to $\mathrm{C}$, the Roman period brooches in this distribution map are mainly Almgren Group VII series 2 and 3 (Almgren 1897). The distribution follows the sailing route along coastal Jæren, the Ryfylke islands, and the Karmsund strait 
and around the alternative sailing routes through portages in the inner fjords, in addition to the rich agricultural areas near Tinghaug at central Jæren. The rosette fibula found at Vårå, where the Karmsund strait narrows just south of Avaldsnes, is generally acknowledged as an insignia of south-Scandinavian elites. This specimen is a Zealand type with links to the Himlingøje/Stevns area (Hansen 1995:261; Hansen and Przybyla 2010; Reiersen 2017:123). A silver brooch type Almgren VII, ser. 3, was found at Innbjoa in Bjoafjord, in a burial containing other elite insignia: a serpent head arm- and finger-ring in gold along with spinning whorls in bronze and silver, contemporary with the princely Flaghaug, grave 2, from the 3rd century (Reiersen 2011, 2017: 256-8). It should be noted that though few in numbers, these early brooches are distributed rather evenly from north to south, but not far into the hinterland or inner fjords. The distribution pattern may relate to routes of communication by sea and to central areas. The distribution of types includes typical late Roman period brooches and other brooches that stand out as indicators of elite networks and high status, such as the rosette fibula by Karmsund, while the silver Innbjoa brooch provides the same references particularly for its combination with other elite insignia. Both these burials with brooches relate to recognised coastal centres by the main sailing route, or where the main sailing route connects with inner fjord-routes (Reiersen 2011:164). In conclusion, the distribution of brooches within the different landscapes displays the earliest tendency toward a relatively higher frequency of brooches at Jæren, a tendency that will be addressed in following periods below. The defining characteristic for this period is the apparent lack of sub-regions, which does not mean they were not there, but rather that brooches were not used to articulate such affiliation or negotiate such identities.

\subsubsection{Roman Iron Age, phase C3 c. 310/320-400}

In the 4th century, there is a general increase in burials with brooches (Fig. 2.4a). New brooch types are introduced, contributing to the definition of $\mathrm{C} 3$ as a chronological phase. Amongst these defining brooches are the Nydam fibulas, equalarmed brooches with triangular endplates, animal-shaped brooches, and silverplated fibulas (Slomann 1977). The Nydam brooch is characterised by its crossbow construction and a knob attached to the top end of the bow, a visible coil often adorned with knobs at each end (Hansen 1970, n. 173). Herein lies the distinction from cruciform brooches that also have three knobs, two at each end of the coil and on at the top of the bow, but positioned along the sides of a rectangular headplate wider than the bow and covering the coil (Hansen 1970; Slomann 1977). Some of the brooches categorised as cruciform by Reichstein (1975) do not follow this distinction, but should rather be seen as C3-protoforms for the cruciform brooches that are developed in the following century (Kristoffersen 2000:62). Simple bow 


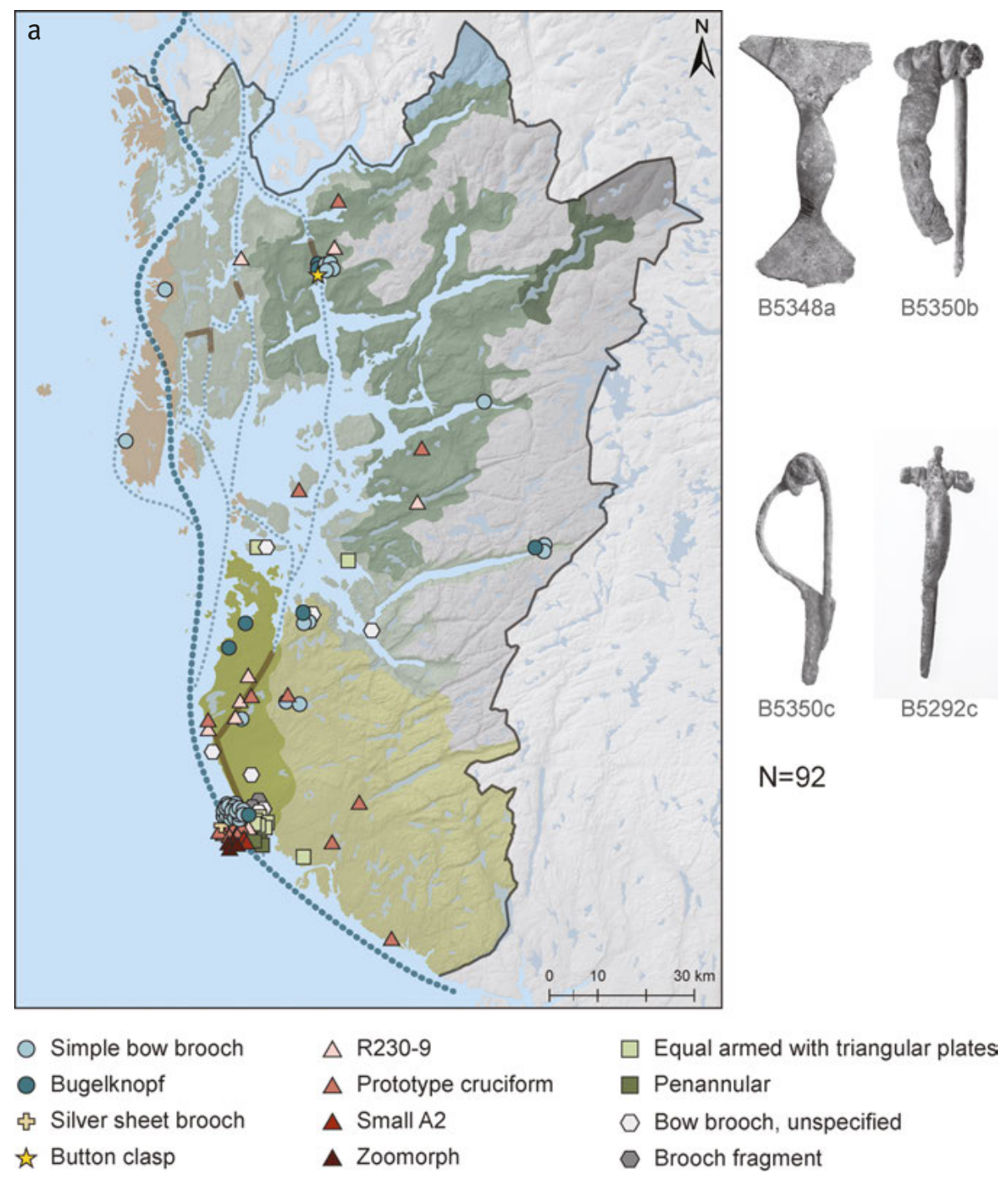

Fig. 2.4a: (a) Distribution of brooches dating to the Roman Period, Illustrative examples: B5348a Equal-armed brooch with triangular ends, B5350b Nydam fibula, B5350c R243/simple bow brooch, B5292c Åk/prototype cruciform; (b) Distribution of burials containing prestigious objects, namely Roman imports, gold, and weapons. The distribution of prestigious objects covers a larger area than the present study area, which is marked by the grey line and the delimitation of landscape districts (after Andersson 1993; Hauken 2005; Myhre 1987). Illustration: M. Østmo, I. T. Bøckman, MCH.

brooches, a common term for brooches of type R243 and related forms, appear in larger numbers from $\mathrm{C} 3$ and continue to be in use towards the late 5th century (Kristoffersen 2006:50; Røstad 2016b:96). 


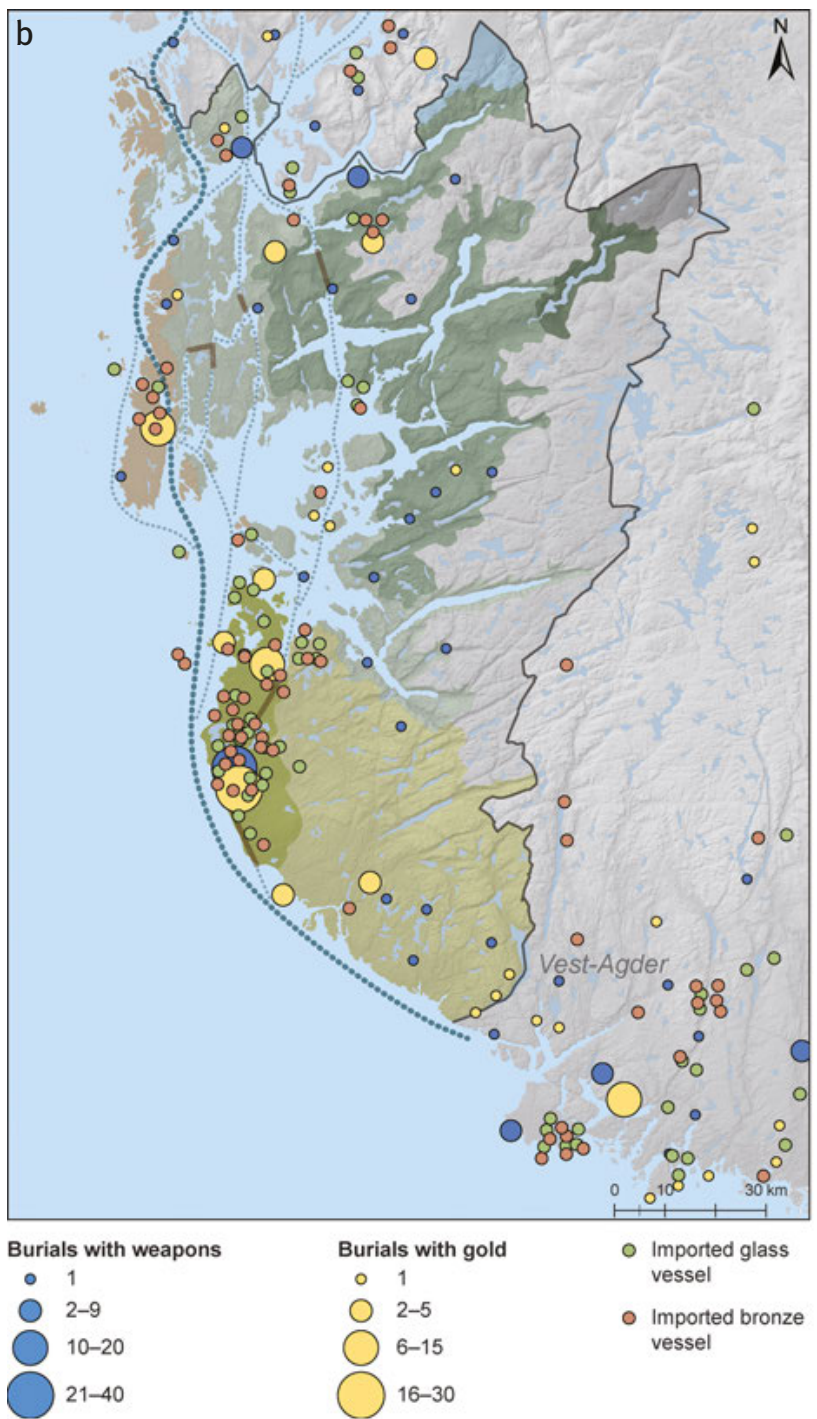

Fig. 2.4b

A large portion of the $\mathrm{C} 3$ brooches are found in burials at Jæren, both along the coast and in the hinterland; a few are also located further in the fjords (Fig. 2.4a). One burial with a pair of iron Niemberger or Haraldsted fibulas was located at Longåker on the western coast of Karmøy (Kristoffersen 2006:table 4). In addition to this burial, only one burial containing a simple bow brooch was located along the outer coast North of the Boknafjord. In comparison, the beaches of Jæren are scattered with burials. More than 600 burial cairns of various shapes have been found to 
form large, continuous cemeteries, termed beach cemeteries, in use from the late Roman Iron Age to the Viking Age, though used most intensively in C3-D2b (Bergstøl 1996; Lillehammer 1996). Disregarding the Longåker burial, the outer coast appears to present a lacuna, leading to questions about the representativity of this distribution. In that respect, it should be emphasized that the distribution of brooches represents only one aspect of society and should not be taken as directly representative for the society or population as a whole (e.g. Näsman 1991:326-7 for a critical approach). Compared to distributions of burials with prestigious objects such as imported vessels of glass or bronze, weapons, and gold, these elite burials display a different pattern. A clustering of Roman period prestigious objects around Avaldsnes underlines the significance of this area, and demonstrates that there are burials there, but they do not contain brooches. Avaldsnes seems to have been well established by this time, with a hall, boathouse, and mortuary monuments (Tab. 2.1). The lacuna of burials with brooches may then be understood not as an indication of the area's low significance with few burials, but rather as a structured difference of practice.

Other mortuary practices also come across as spatially structured; for example, oblong or oval outer monuments are clearly bound to Jæren, while round mounds or cairns are the dominant form in the remaining areas (Fig. 2.5b). Similarly, the body of the deceased is treated differently across the study area (Fig. 2.5c). At Jæren inhumation is prevalent, and the same tendency may be observed in the very few burials found on the outer coast or outer fjord districts. In the heathland/moorlands and middle fjord districts, however, cremation is practiced at much higher frequencies. The treatment of the dead is presumably linked to cultural understandings and dispositions regarding what constitutes a proper burial and the transformation from the sphere of the living to the sphere of the dead. Another aspect of mortuary practices is the reuse of burial monuments. In C3, reuse of monuments is present in all landscape regions (Tab. 2.3). Jæren stands out in that as many as $22 \%$ of the burials with brooches are primary burials in monuments that were subsequently reused in the same or in following periods.

In conclusion, the sub-regions inferred in this period are Jæren, Karmsund/outer coast, the Ryfylke islands in the outer fjord district, Bjoafjord and Jøsenfjord in the middle fjord districts, and a few very local distributions in the heathland/moorland. The articulation of difference with respect to neighbouring areas comes across most clearly at Jæren, characterised by the most complex variations in brooch types, though clearly dominated by simple bow brooches, in addition to construction of oblong or oval cairns/mounds and the practice of inhumation. Reuse of burial monuments is seen in all landscapes, but the frequency with which burial monuments would be reused in following periods is generally high at Jæren, indicating the continued significance of the burials with brooches for the people living there. Karmsund on the outer coast, including the socio-political centre located at Avaldsnes, is characterised by its lack of depositing brooches in burials. The three remaining landscape regions are defined by nuances. They are not substantially divergent from their 


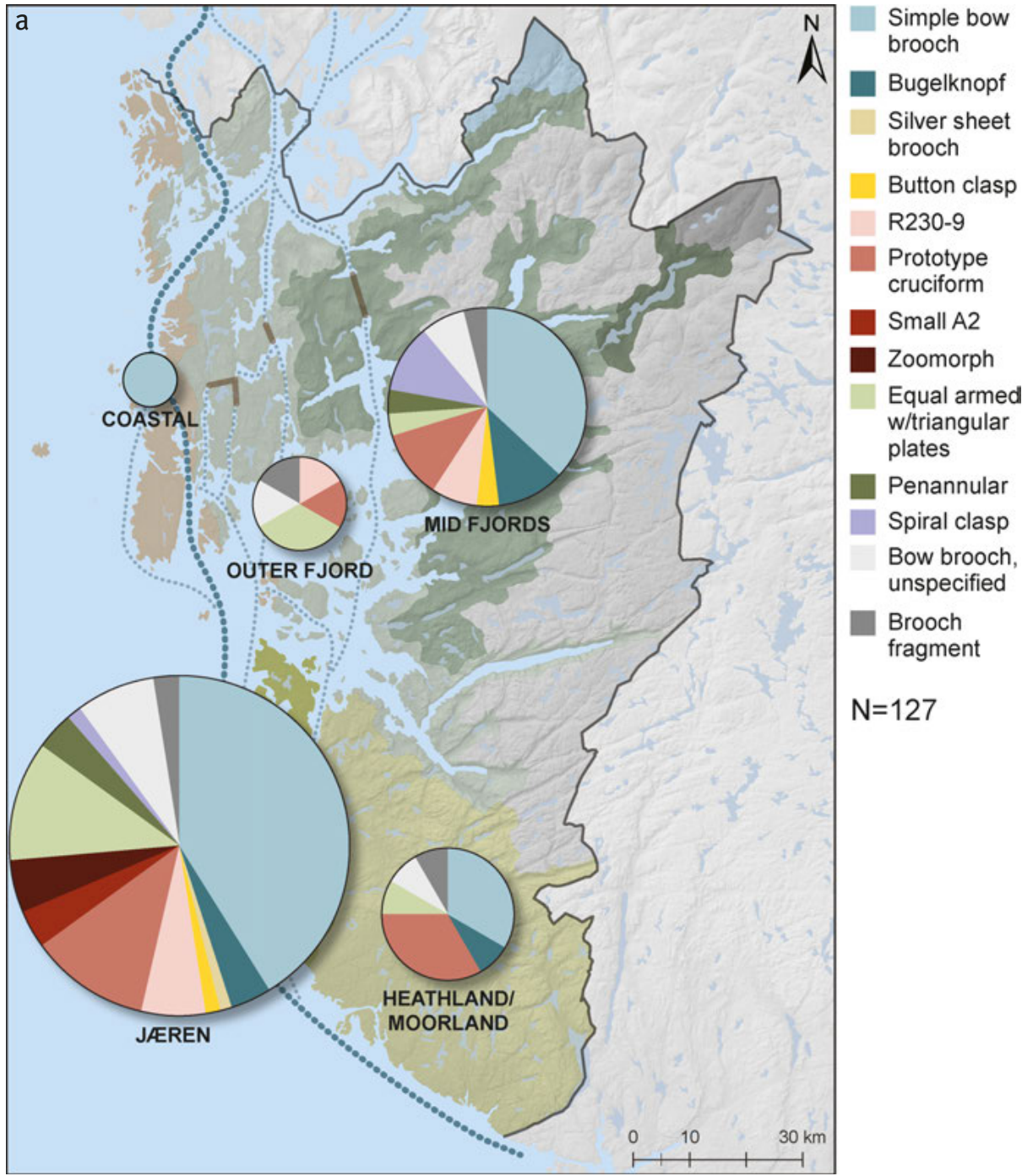

Fig. 2.5a: Frequencies of (a) brooch types, (b) outer monument form, and (c) the treatment of the deceased in the period C3. Landscape districts after Puschmann (2005)/NIBIO. Illustration: M. Østmo, I. T. Bøckman, MCH.

neighbouring landscapes; rather, they are similar in some aspects, different in others. For example, the outer fjord burials, in this period located mainly on the Ryfylke islands, feature predominantly round monuments similar to the heathland/moorland, but inhumation is prevalent as at Jæren. The heathland/moorland has brooches similar to Jæren but cremation is prevalent. The distribution of burials with brooches displays the most evident contrast between Jæren and Karmsund. 


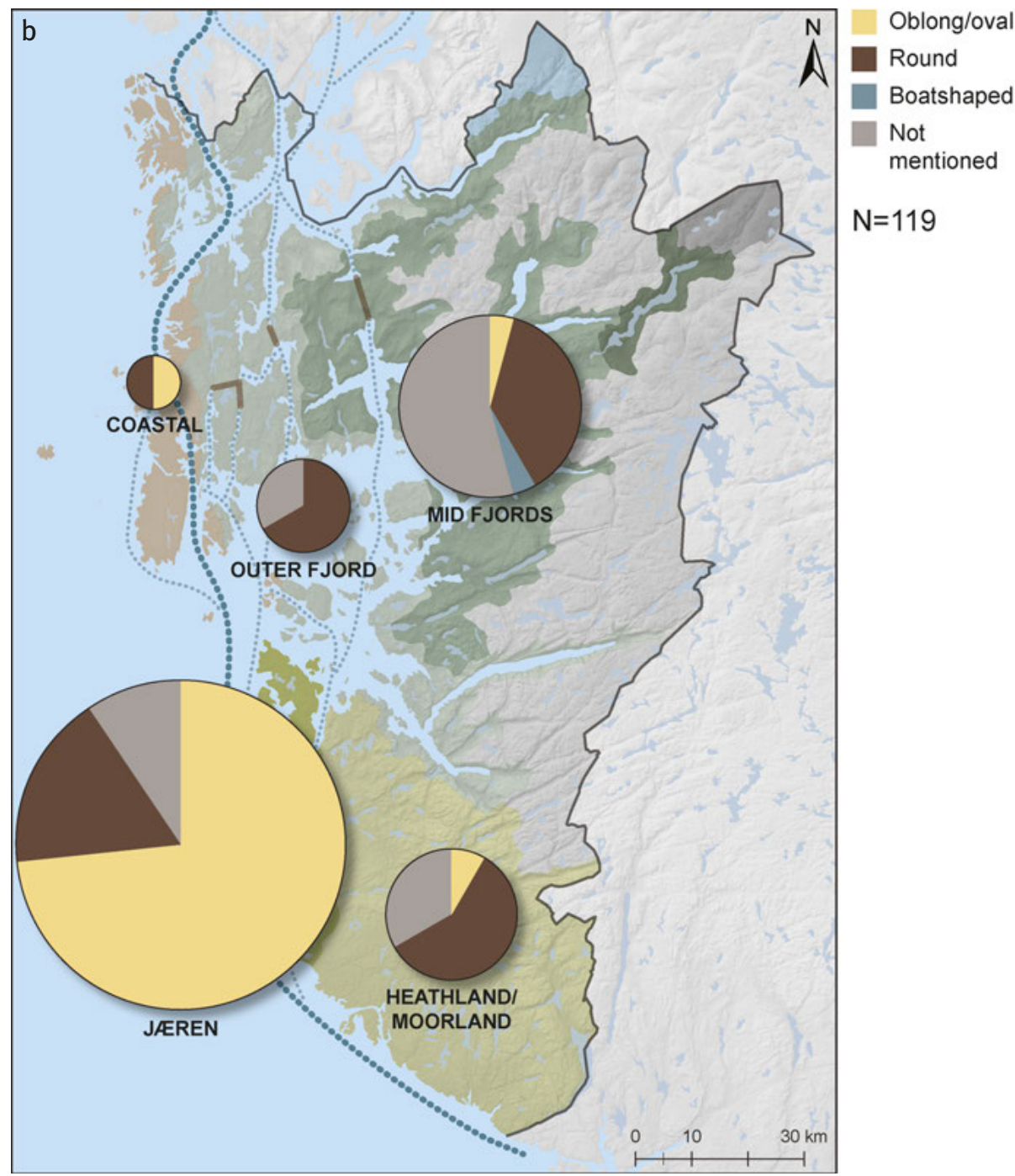

Fig. 2.5b

\subsubsection{Migration Period c. 400-550}

The fully developed cruciform brooch marks the beginning of the Migration Period. Cruciform brooches belong to sub-phases D1 and D2a, 400-75 and 475-525 respectively (Kristoffersen 1999; Kristoffersen and Magnus 2010). The production of cruciform brooches is assumed to have ceased towards the late Migration Period, as they are not found together with the late relief brooches, nor with the equal-armed 


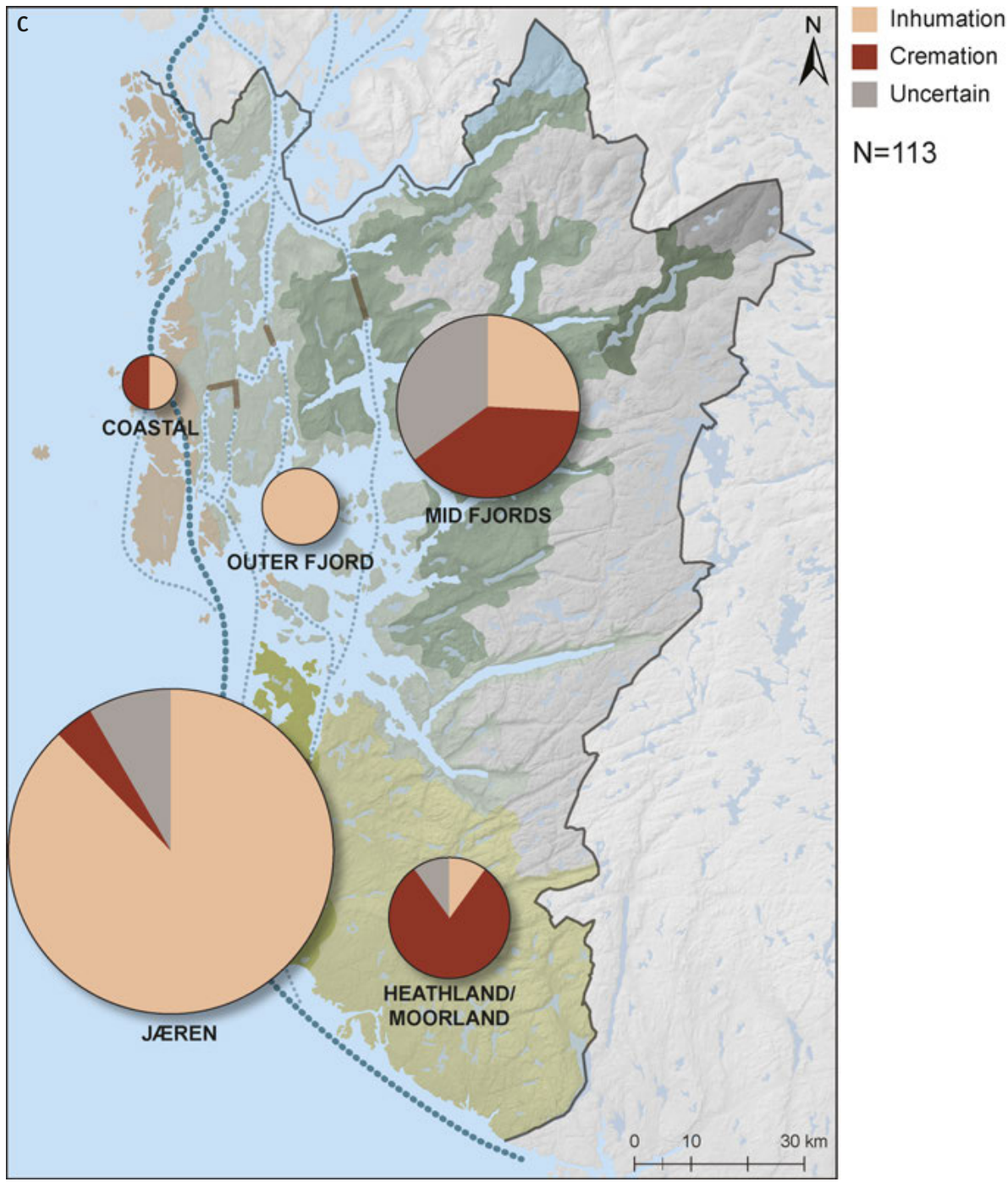

Fig. 2.5c

brooches without endplates, both dated to D2b, 525-50 (Kristoffersen 2000:70, $82-3)$. The distribution of cruciform brooches consolidates the spatial patterns established in C3: large clusters at Jæren, both in the hinterland and along the beaches. The contrast to the outer coast and Karmsund is clear, as no cruciform brooches are found here (Fig. 2.6a, b). Amongst the brooches, there are subgroups such as the cruciform type Mundheim, which is found in all landscape regions where cruciform brooches are in use. This subtype is termed southwest Norwegian by Reichstein, but appears in fact all along the western coast, parts of the northern 
Tab. 2.3: Overview of singular use versus reuse of monuments in the late Roman Period. Note that reuse may be under-represented due to poor documentation in several burials. All burials where the artefacts do not indicate several individuals or documented secondary phases are listed as singular use.

\begin{tabular}{lcccr}
\hline $\begin{array}{l}\text { landscape } \\
\text { district }\end{array}$ & 8 & $\begin{array}{r}\text { Only known grave } \\
\text { in monument }\end{array}$ & $\begin{array}{r}\text { Primary grave in later } \\
\text { reused monument }\end{array}$ & $\begin{array}{r}\text { Secondary burial in } \\
\text { reused monument }\end{array}$ \\
\hline $\begin{array}{l}\text { Heathlands/ } \\
\text { Moorlands }\end{array}$ & $\mathrm{N}=11$ & 41 & 13 & 3 \\
\hline Jæren & $\mathrm{N}=59$ & 1 & 1 & 5 \\
\hline Outer coast & $\mathrm{N}=1$ & 3 & 2 & 1 \\
\hline Outer fjords & $\mathrm{N}=5$ & 11 & 3 \\
\hline Mid fjords & $\mathrm{N}=16$ & & & \\
\hline
\end{tabular}

coast and eastern Sweden (Røstad 2016a:120-1). Thus, it bears witness to the interconnectedness of Scandinavia at this time. At the same time, there are local distributions of other sub-types, such as Byrkje.

The spatial pattern formed by the relief brooches comprises fewer specimens than the cruciform brooches (Fig. 2.6a, b). While they repeat the general distribution pattern, they cluster and display more diversity and higher quality at southern and central Jæren, particularly in connection with the Tinghaug complex. It should be mentioned that a relief brooch (S9269), interpreted as part of a goldsmith hoard in combination with clasps and a gold ingot, was uncovered at Syre, on southern Karmøy (Kristoffersen 2012:172; Zachrisson 2018:706). This indicates that such brooches were in fact available, though still not selected for deposition in burials in this sub-region.

All clasp types (Fig. 2.6c) are found at Jæren, while two parallel tendencies apply for the remaining landscapes: spiral clasps, dating mainly to D1, are distributed along the middle fjords, where local and regional communication routes should be expected; and slightly younger button clasps follow sailing routes along the outer coast and outer fjords, where they are located at strategic spots, such as the burial at Storasund, Karmøy, which also contained a single simple bow brooch.

Jæren is characterised by a high diversity of sub-types, several located solely at Jæren: Ådland, Fristad, Shetelig small brooches of types A4 and B6, a shieldshaped brooch from Krosshaug, S-shaped brooches from Kvassheim, and a few unique or rare clasps. A single rare clasp is also found in the southernmost part of the outer fjord area (Figs. 2.6c, 2.7b). Another aspect of mortuary practices appears to be closely bound to Jæren: burials furnished with three or more identical brooches. This practice is not widely spread; the brooches used in such large sets are simple bow fibulas or cruciform brooches. They are located mainly at the beach 


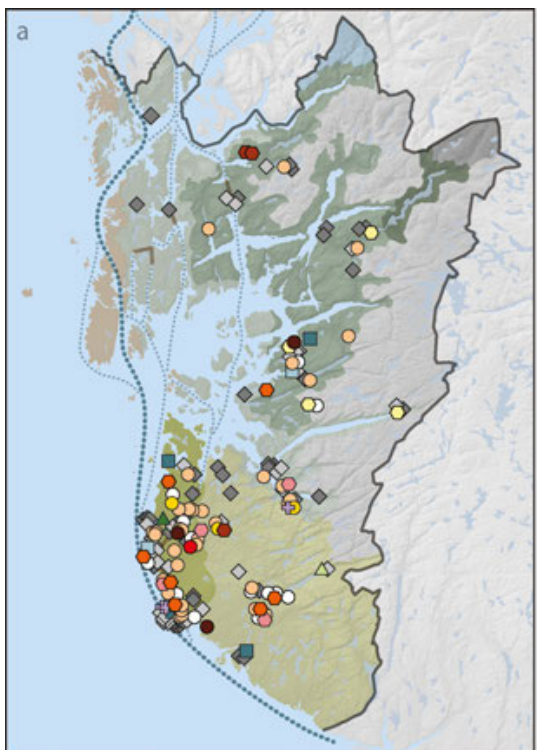

Æ Prototype cruciform

$\square$ Eine

$\square$ Lunde

$\triangle$ Bützfleht

$\Delta$ Fristad

$\diamond$ Cruciform unique

$\diamond$ Cruciform unspecified

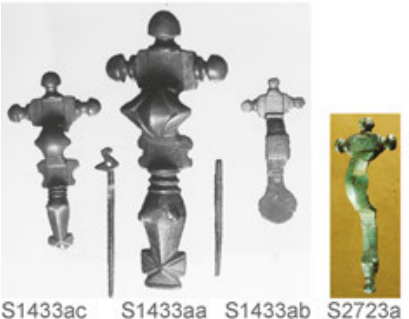

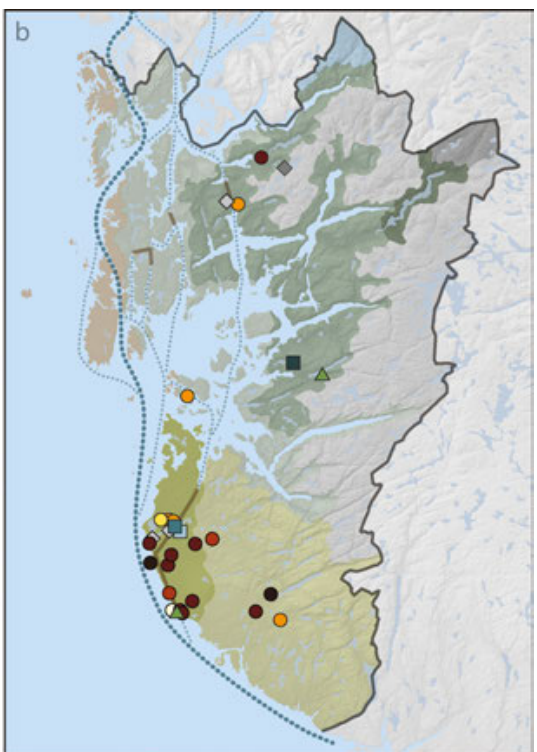

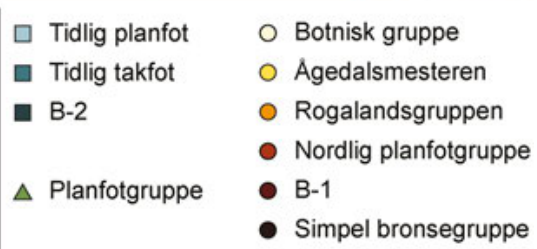

$\diamond$ Relieff unique

$\diamond$ Unspecified

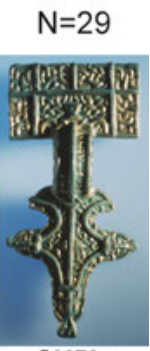

S2276a

Fig. 2.6a-b: Distribution of (a) cruciform brooches, (b) relief brooches and (c) clasps, and (d) a distribution of burials with 3-5 identical brooches. While several of the brooch types overlap, the cruciform brooches are not found with the latest relief brooches of Style 1 ornamentation, the latter belonging to sub-phase D2b. Illustrative examples: Cruciform: S1433ac+aa Mundheim, S1433ab Søndre Gammelsrød, S2723a cruciform unique, C4924 Lima; Relief brooches: S307 B-1 (spatulate foot), S4752 Nordlig Planfotgruppe, S2276a Rogalandsgruppe; Clasps: S2718c Spiral clasps, S7577a Rare/Unique, S9181a Button clasps. Landscape districts after Puschmann (2005)/NIBIO. Illustration: M. Østmo, I. T. Bøckman, MCH. 

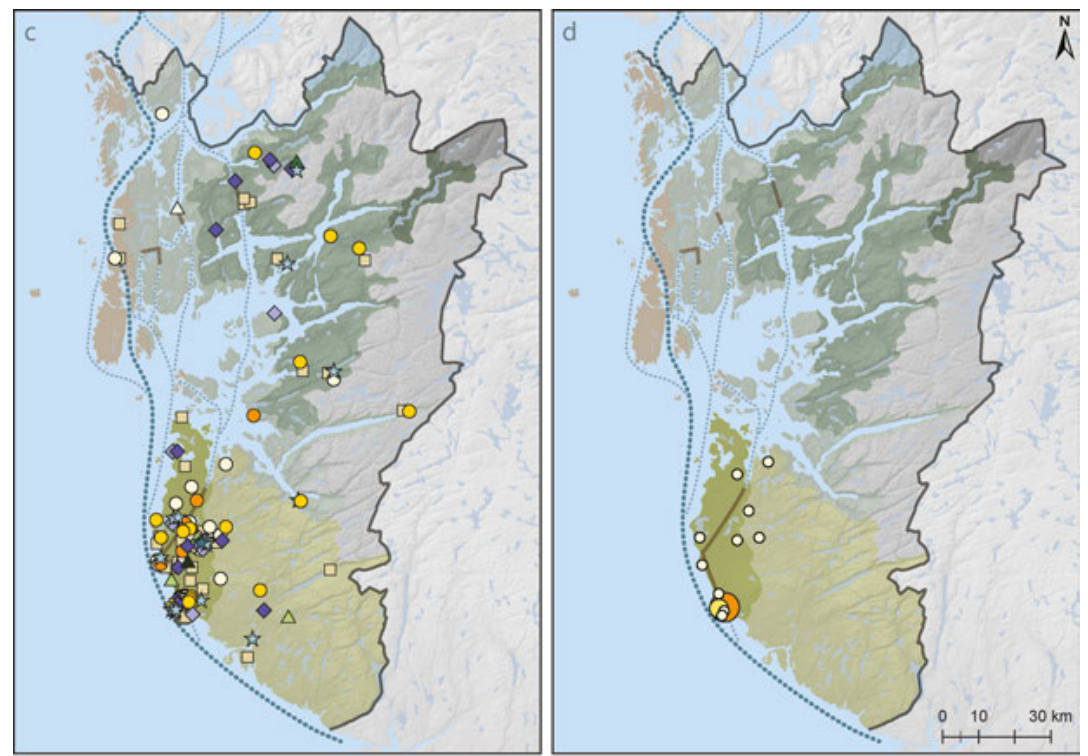

S shaped

$\triangle$ Small B3

$\triangle$ Small B4

s. Small A2

$\Delta$ Small B5

Small A4

A Small B6

$\square$ Simple bow brooch

Equal armed with endplates

$\checkmark$ Equal armed without endplates

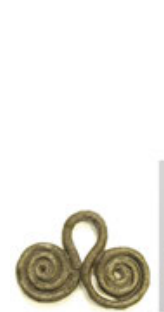

S2718c

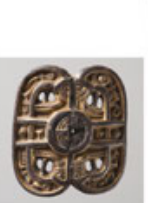

S7577a
Button clasp Spiral clasp

- Rare/unique clasp

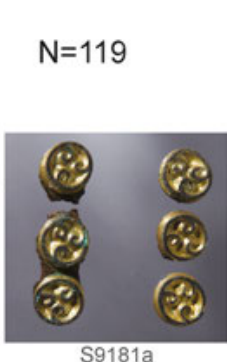

- 3 of a kind

- 4 of a kind

- 5 of a kind

$N=16$

Fig. $2.6 c-d$ 


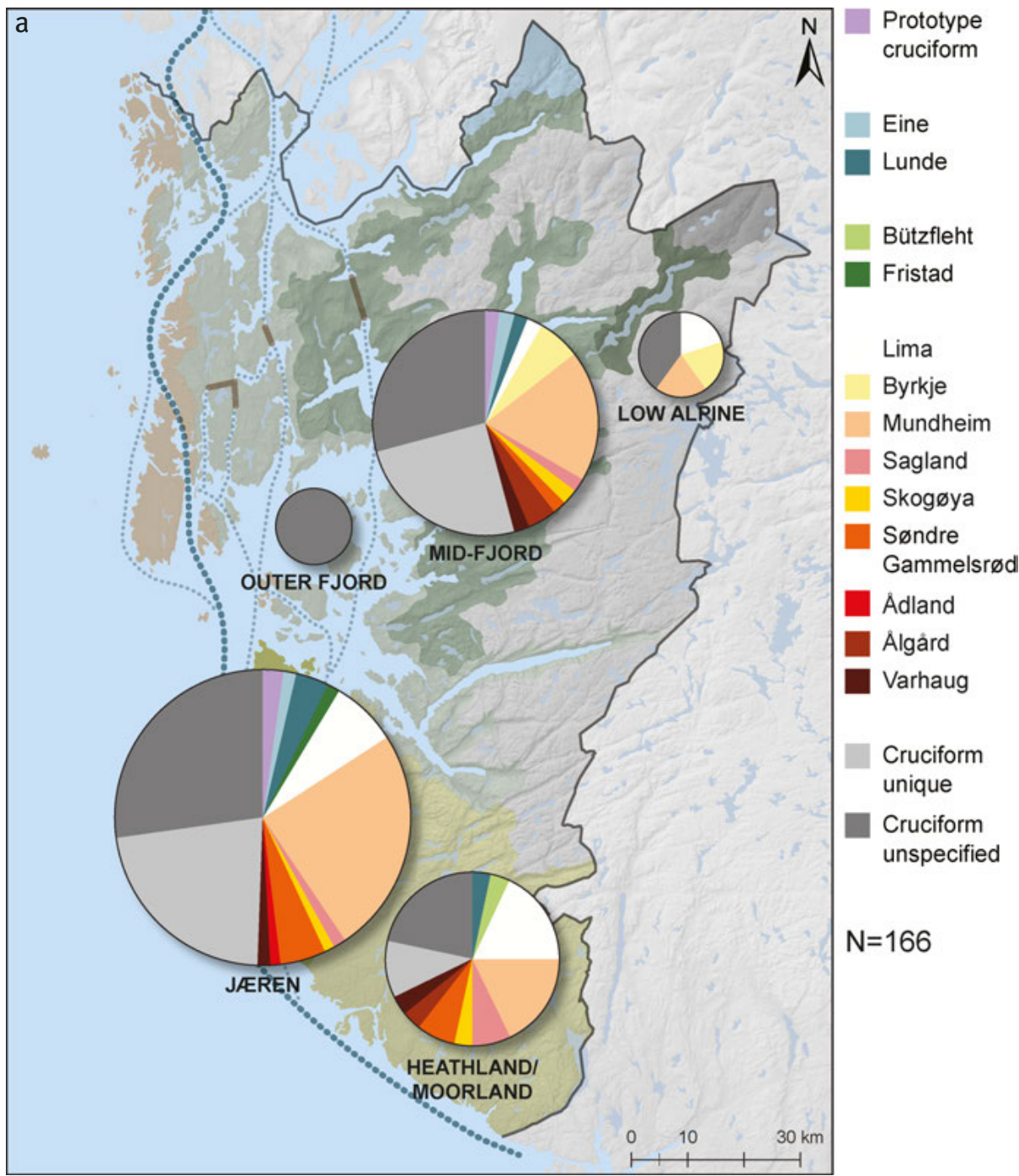

Fig. 2.7a: Statistical illustration of the spatial structuring of (a) cruciform brooches, (b) clasps and relief brooches, and of aspects of burial practices as (c) monument form and (d) body treatment. Landscape districts after Puschmann (2005)/NIBIO. Illustration: M. Østmo, I. T. Bøckman, MCH.

cemeteries, but a few examples are found further inland along the transition between Jæren and the heathland/moorland towards the northeast (Fig. 2.6d).

As in period C3, inhumation and monuments of oblong/oval form are prevalent at Jæren (Fig. 2.7c, d). The contrast to the heathland/moorlands observed in C3 is not upheld in the Migration Period. The heathland/moorlands have fewer burials and accordingly fewer sub-types. Two of these display local distribution, where Shetelig's 


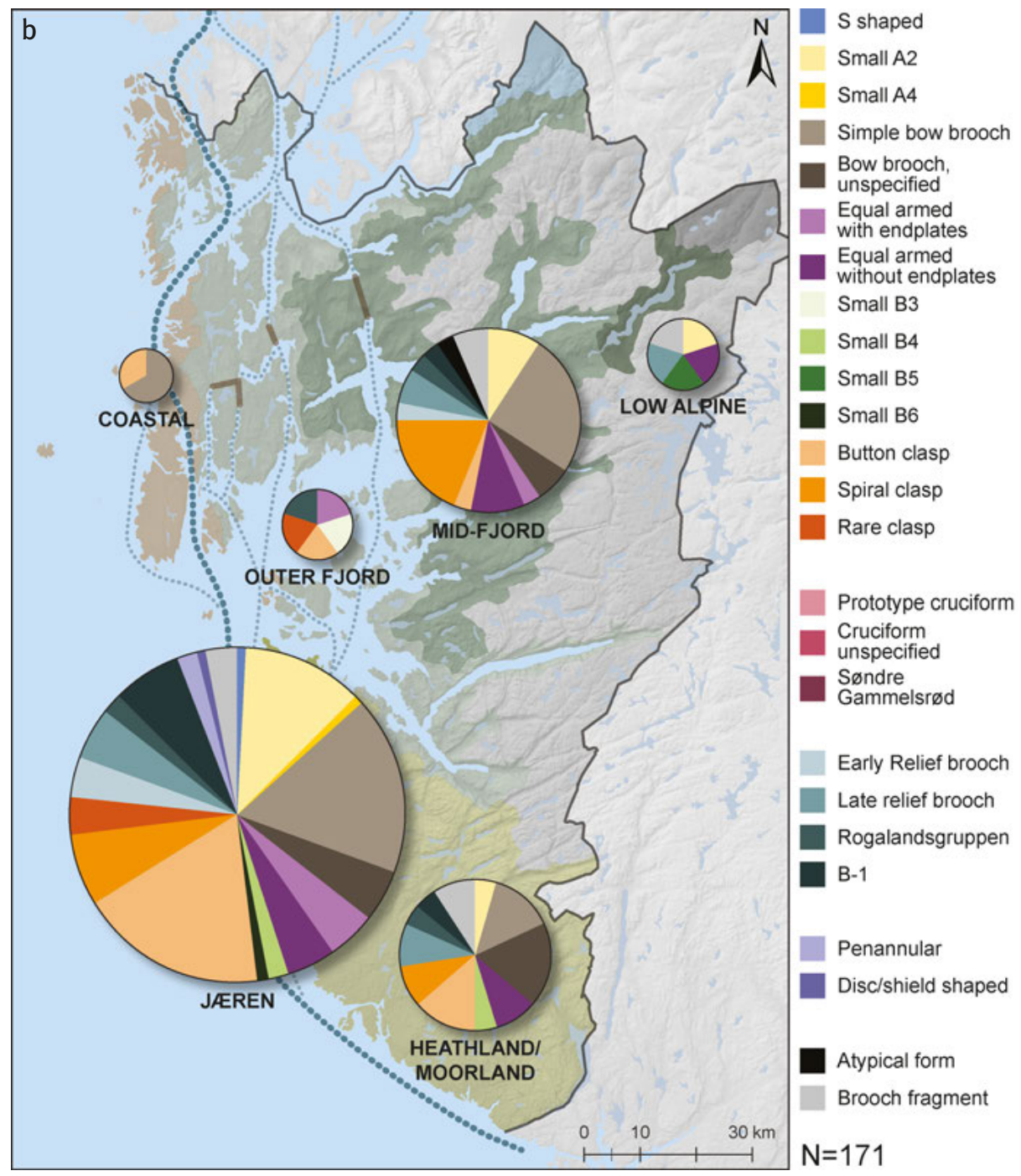

Fig. 2.7b

small brooches of type B4 and cruciform Ålgård are common with Jæren and the middle fjord districts respectively. The marked difference compared to Jæren in C3 - the practices of cremation and round monuments - is relatively muted. Increased similarity with Jæren could imply that these sub-regions were more integrated with each other in the Migration Period. The opposition toward the outer coast and Karmsund, however, is even more pronounced than in C3. The burial with a button clasp combined with a simple bow-brooch at Storasund and recent metal-detector finds not 


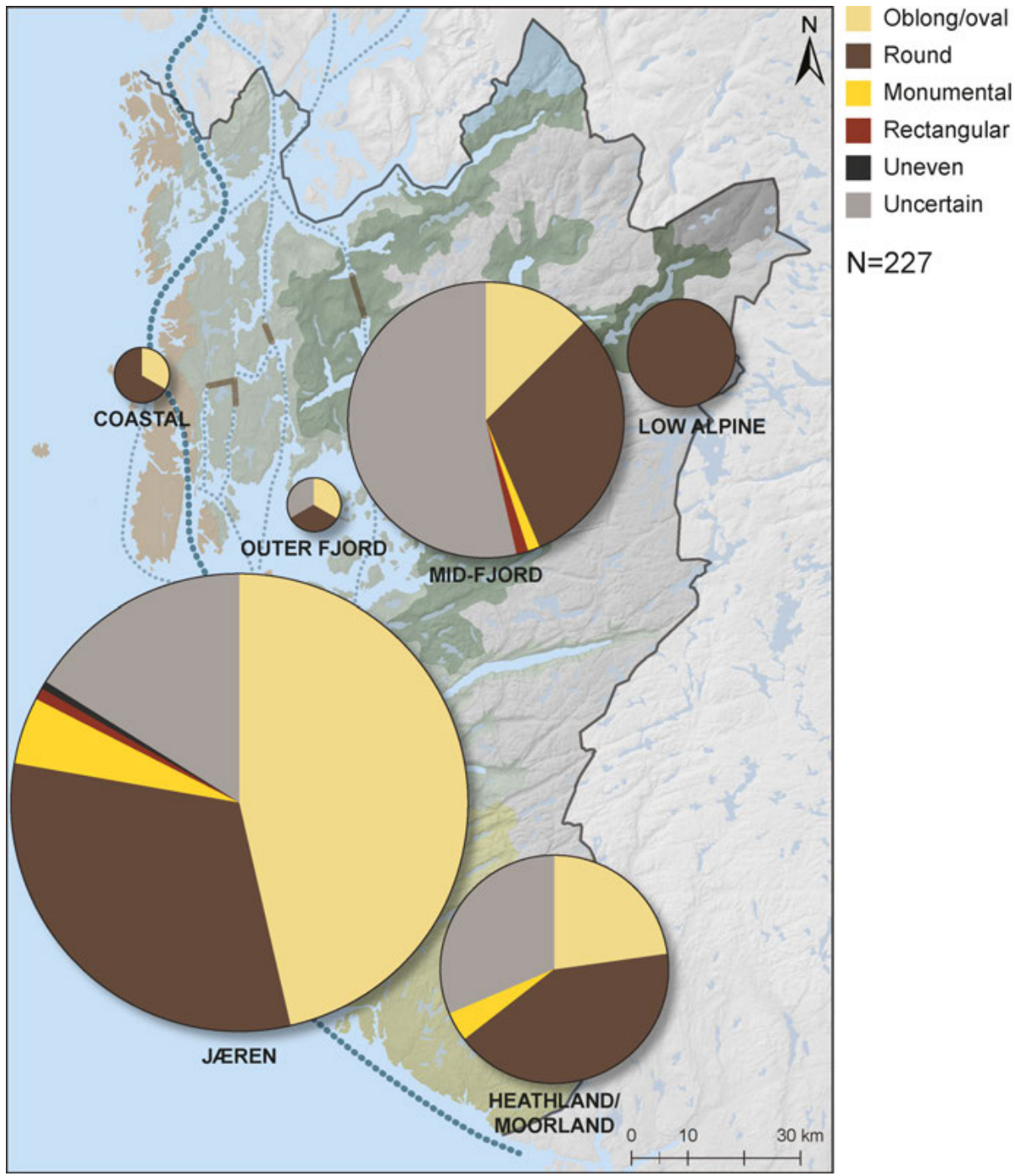

Fig. 2.7c

included in the present analysis could imply the use of small brooches in this subregion (Skre pers. comm., and S13812).

As seen in Tab. 2.4, 27.5\% of the burials at Jæren are interred as secondary burials, a relatively high proportion compared to the other sub-regions. The frequency with which the monuments of burials with brooches are subject to later reuse at Jæren is approximately $10 \%$. In comparison, both the middle fjords and the heathland/moorland districts show slightly lower frequencies for secondary burials, both approximately $10 \%$. There is a slight increase in the frequency of burials with brooches in the 


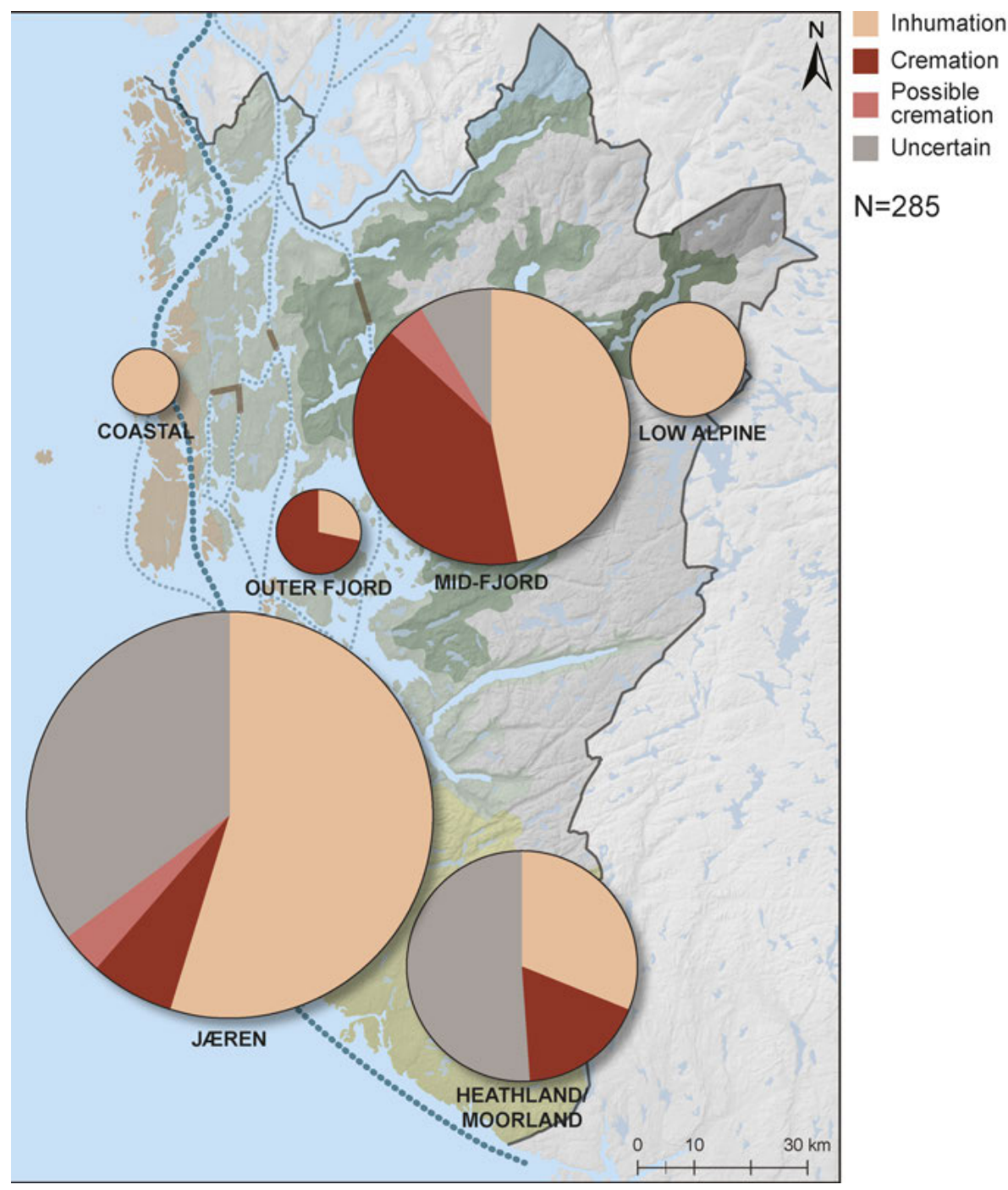

Fig. 2.7d

middle fjords and heathland/moorland that were later subjected to secondary use, displaying a slightly delayed tendency compared to the trajectory at Jæren.

In conclusion, the most clearly defined sub-regions are Jæren, the combined middle fjord and low alpine region, and the Karmsund on the outer coast. The latter is characterised first and foremost by its lack of cruciform and relief brooches. The outer fjord districts have undergone changes from the previous period, as burials with brooches with two exceptions now appear on the mainland north or south of the Boknafjord, rather than on the islands. The compilation of brooch types is not 
Tab. 2.4: Overview of singular use versus reuse of monuments in the Migration Period. See Tab. 2.3 for general comments.

\begin{tabular}{llrrr}
\hline $\begin{array}{l}\text { landscape } \\
\text { district }\end{array}$ & $\begin{array}{r}\text { Only known grave } \\
\text { in monument }\end{array}$ & $\begin{array}{r}\text { Primary grave in later } \\
\text { reused monument }\end{array}$ & $\begin{array}{r}\text { Secondary burial in } \\
\text { reused monument }\end{array}$ \\
\hline Low alpine & $\mathrm{N}=10$ & 4 & 4 & 2 \\
\hline $\begin{array}{l}\text { Heathlands/ } \\
\text { Moorlands }\end{array}$ & $\mathrm{N}=47$ & 39 & 3 & 5 \\
\hline Jæren & $\mathrm{N}=182$ & 115 & 17 & 50 \\
\hline Outer coast & $\mathrm{N}=3$ & & 2 & 1 \\
\hline Outer fjords & $\mathrm{N}=8$ & 7 & 1 & 8 \\
\hline Mid fjords & $\mathrm{N}=75$ & 55 & 12 & \\
\hline
\end{tabular}

very informative - the northern area mainly comprising unspecified cruciform brooches. Thus, the outer fjord region north of the Boknafjord is still set apart from Karmsund on the outer coast, but is also slightly different from the middle fjord region where a more diverse use of brooches may be seen.

The middle fjord area, together with the bordering low alpine areas, seems to form an integrated sub-region, set apart mostly by not sharing the same local brooch types as found at Jæren, a mixed practice with both cremation and inhumation, and prevalent round monuments. The burials with brooches in the low alpine landscape in Etne and in Dyraheio are located close to the borders with the middle fjord landscapes. The cruciform type Byrkje is only found in these two landscape regions. The practice of reusing burial monuments is seen in these landscapes as well, but not as frequently as at Jæren. The frequency in which burials with brooches from this period will be subject to later reuse approaches that of Jæren.

Jæren is distinguished by a complex brooch corpus, several types of which are found only here. Large brooch sets with more than two identical brooches as a practice is also bound to Jæren. As in the previous period, the oblong/oval monuments and inhumation are prevalent, forming a contrast to the middle fjord region. The Heathland/Moorland seems more assimilated with Jæren in terms of both brooch selection and burial practices.

\subsubsection{Merovingian Period c. 550-775/800}

A slight quantitative decline in the number of burials with brooches is observable already in D2b, as the cruciform brooches go out of circulation (Røstad 2016a:307). Entering the Merovingian Period, this tendency becomes blatantly clear (Fig. 2.8 for details), and is perhaps particularly visible in contrast to the many burials in south- 

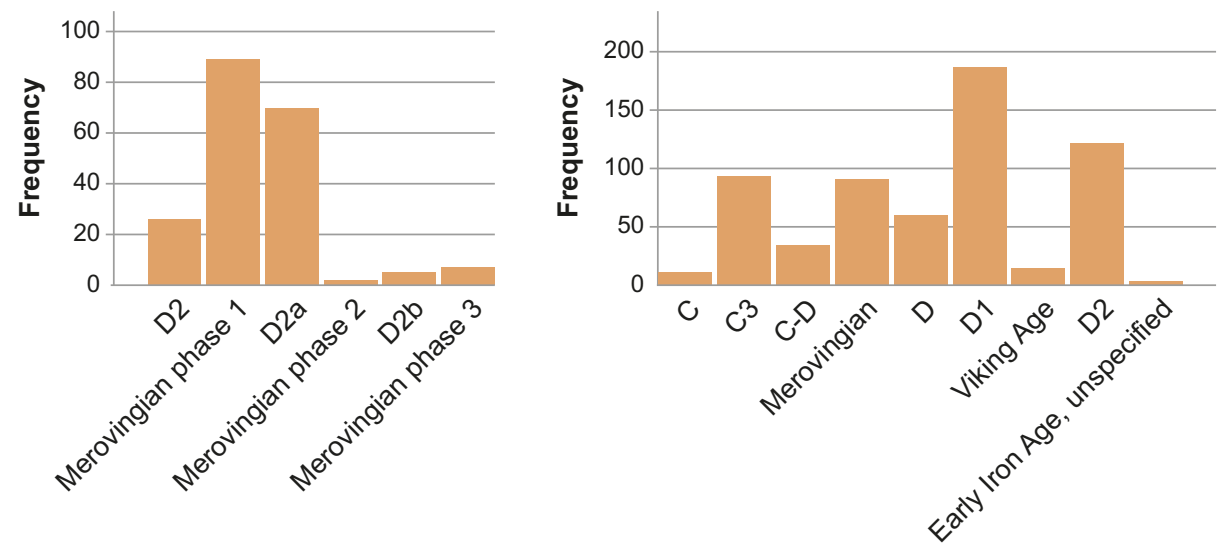

Fig. 2.8: Chronological distribution of brooches within the study area; see the general overview (top) and more detailed presentation of the dramatic decline in burials in the transition to the Merovingian Period (bottom). Illustration: M. Østmo, I. T. Bøckman, MCH.

western Norway in the previous period (Solberg 2000:176-87). This decline in burials relates to a vast corpus of research on abandoned farms and changes in settlement patterns, and increasingly accounting for the AD 536 dust veil's effect on demography, but also on mythology (e.g. Gjerpe 2017:194-7; Gräslund and Price 2012; Iversen 2013:181-91; Myhre 2002). The decline in burials may also have been enhanced by generally less visible or unmarked graves. In addition, less conspicuous artefacts such as conical brooches may have been overlooked and consequently do not appear in the museum inventories. The increase in metal-detector activity in recent years has produced several new Merovingian brooches, providing new insights into practices and networks of the period. The unfortunate lack of documented contexts means that much information is forever lost.

The conical brooches and equal-armed brooches date to Merovingian Phase 1, AD 550-650 (periodisation in accordance with Røstad 2016a). In the present study area, only one conical brooch has been found in a burial context, but eight conical brooches of either geometric or animal art/style II decoration have been located by recent metal-detecting. Due to their significance for the overall distribution, they are included in the map, but lack context information for further analysis (included in Figs. 2.9a, but not 2.10). In the early Merovingian Period, burials seem to have a coastal focus, as they are located at Jæren, the outer fjords and at the transition to the middle fjords. The middle fjord area is otherwise devoid of brooches; none are found at the Ryfylke islands or the inner fjord area. This pattern is repeated in Merovingian phases 2 and 3, AD 650-725 and 725-800 respectively, now including more types, with Jæren marked by the highest diversity. The four disc-on-bow brooches found at Jæren and one specimen in the heathlands/moorlands constitute a significant fraction of the 53 such brooches found in Norway (Røstad and Glørstad 


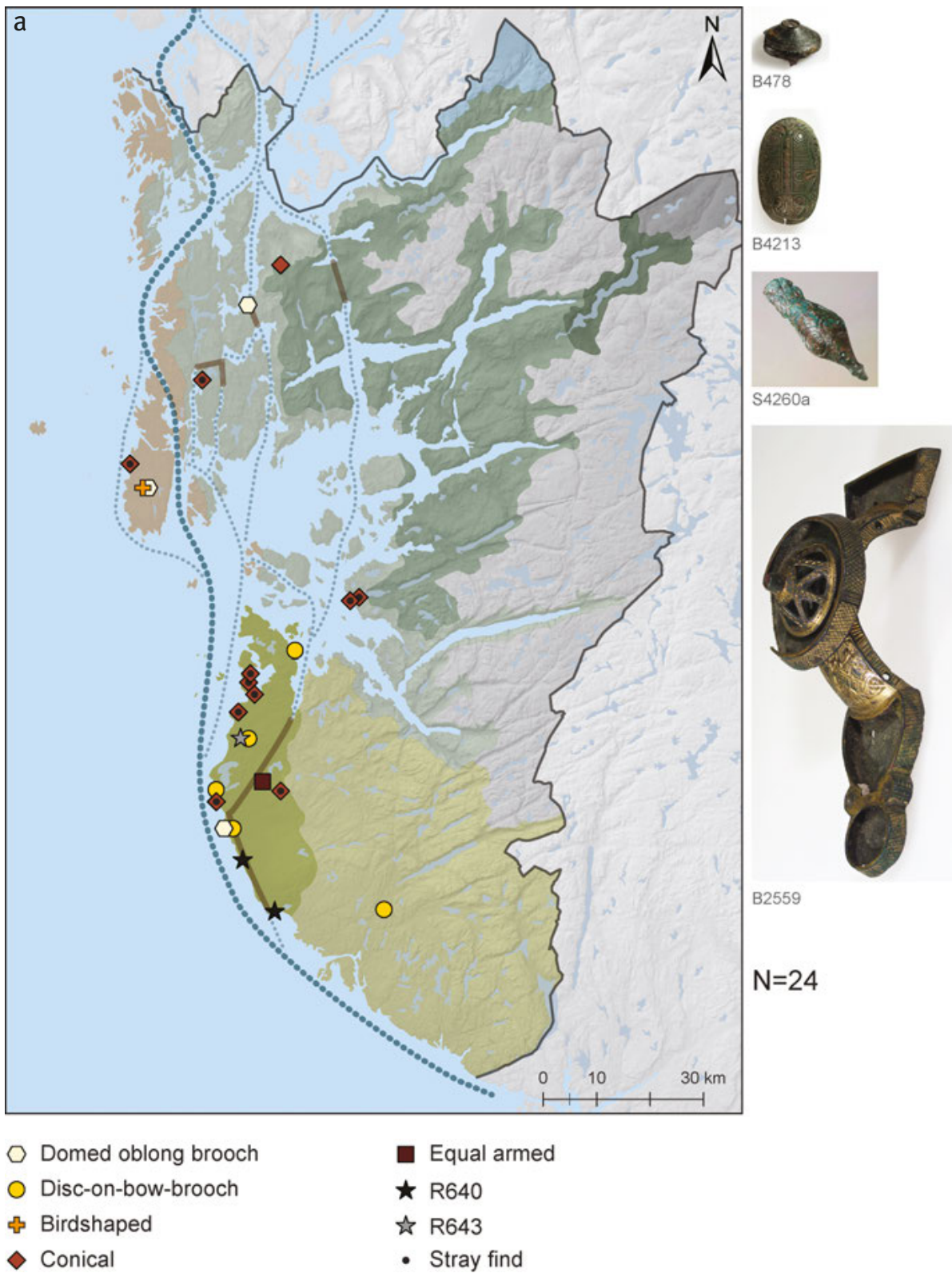

Fig. 2.9a: Distribution of (a) brooches from the Merovingian Period, (b) the Storhaug ship burial by Karmsund containing a horse (marked by star) and other burials with horses/equestrian equipment from the 8th century (marked by dots) (after Meling 2014: fig. 4). Illustrative examples: B478 conical brooch, B4213 domed oblong brooch, S4260a Bird shaped fibula, B2559 disc-on-bow brooch. Landscape districts after Puschmann (2005)/NIBIO. Illustration: M. Østmo, I. T. Bøckman, $\mathrm{MCH}$. 


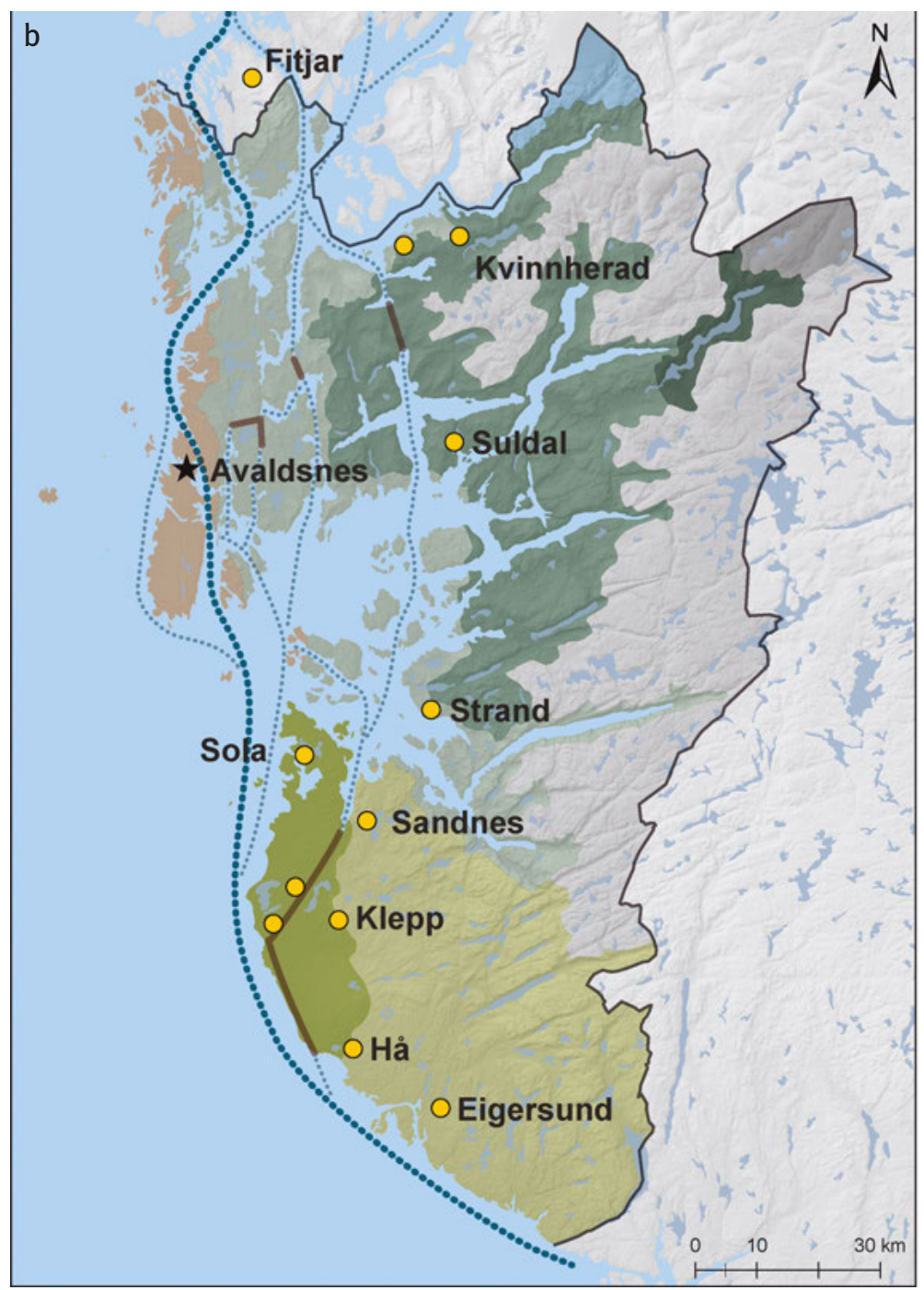

Fig. 2.9b

2015:186-7). It should be noted that the brooches from Orre and Sagland, both on Jæren, might have been interred significantly later than their time of production. Both were found together with oval brooches of type JP 33/37 dating to the Viking Period 1/2a, AD 750/775-860 (periodisation in accordance with Klæsøe 1999). It is not unusual for disc-on-bow brooches to have been handed down between generations before they are interred, and their status as heirlooms and representations of family genealogy has been argued (Røstad and Glørstad 2015). Contrary to previous periods, 


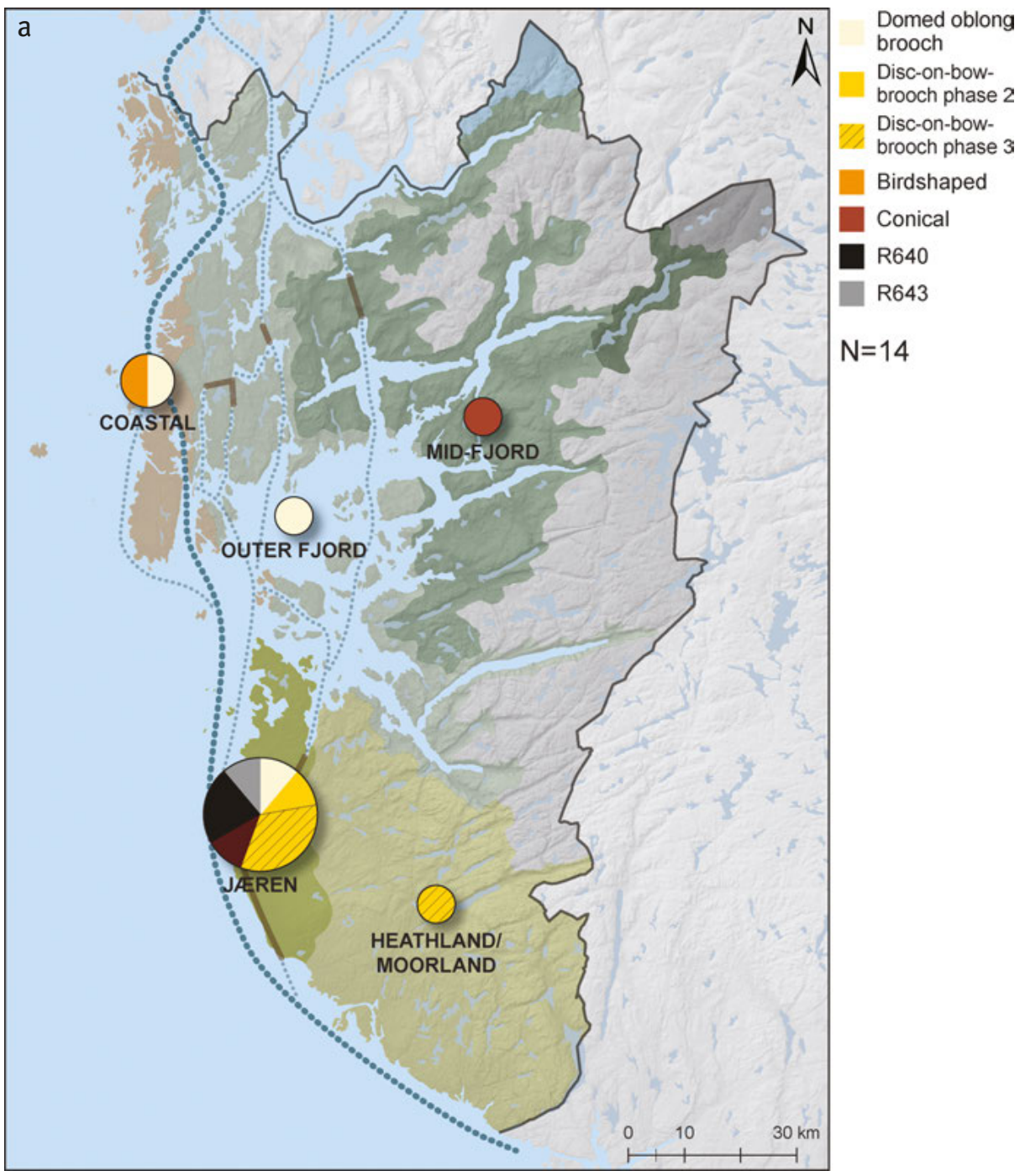

Fig. 2.10a: Statistical frequency of (a) brooch types in the Merovingian Period, (b) monument form, and (c) treatment of deceased body. Landscapes districts after Puschmann (2005)/NIBIO. Illustration: M. Østmo, I. T. Bøckman, MCH.

Karmøy no longer stands out as a lacuna amongst landscapes scattered with brooches. The brooches at Ferkingstad were located in a small Merovingian period cemetery with unmarked graves (Figs. 2.9a, 2.10c). Amongst the objects from these graves is a rare bird-shaped brooch; only nine of this kind have been uncovered in Norway. As the bird brooch is not of local production, it indicates connections to 


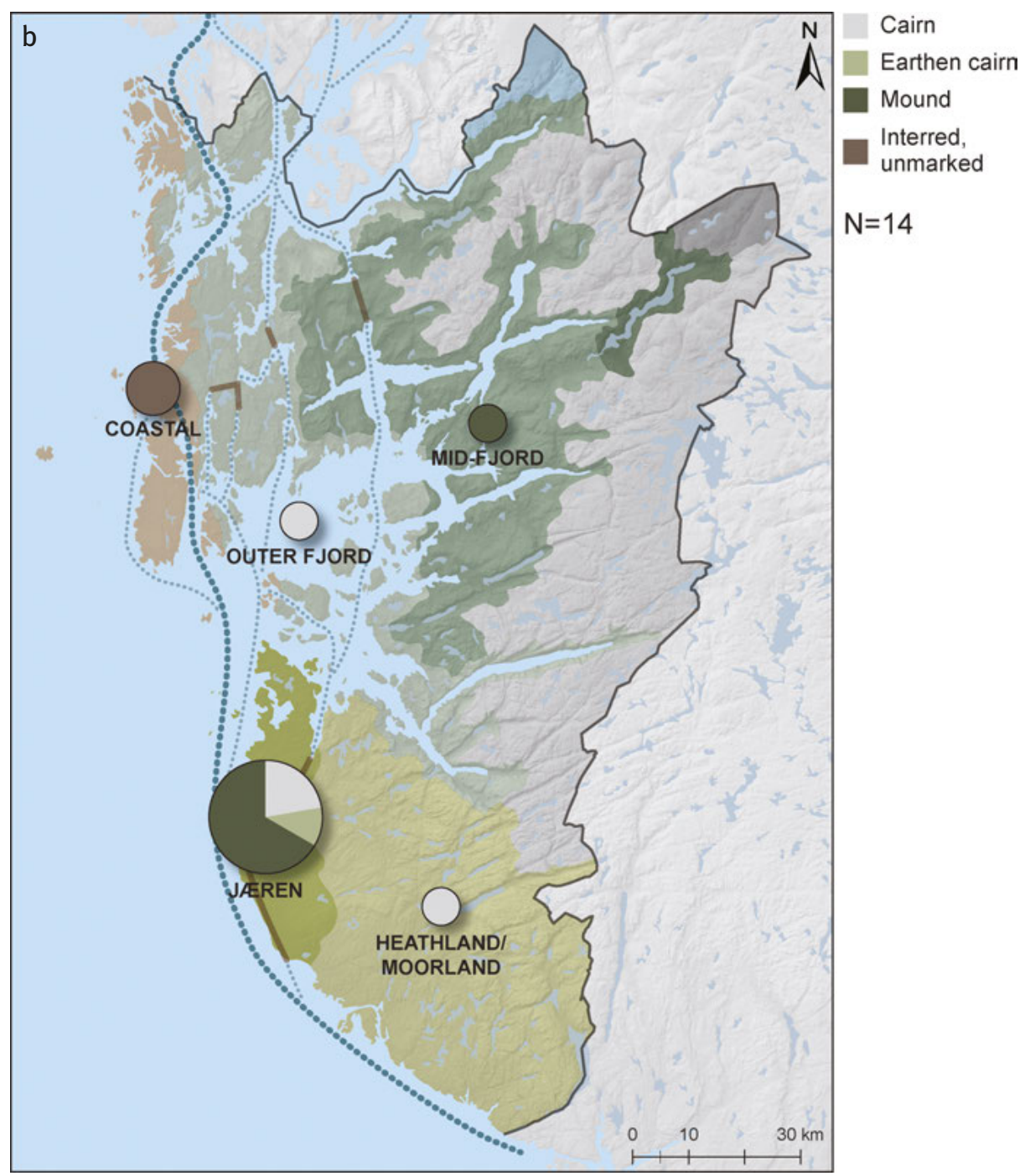

Fig. 2.10b

other places of production in southern Scandinavia, possibly Bornholm (Opedal 2010:57; Røstad 2008).

The locations for the burials with brooches are strategic with respect to routes of communication and resemble that of late Roman Period C1b-C2. The burials with brooches correlate quite well with the distribution of burials with horses or equestrian equipment (Fig. 2.9b). The latter have been interpreted as elite burials due to 


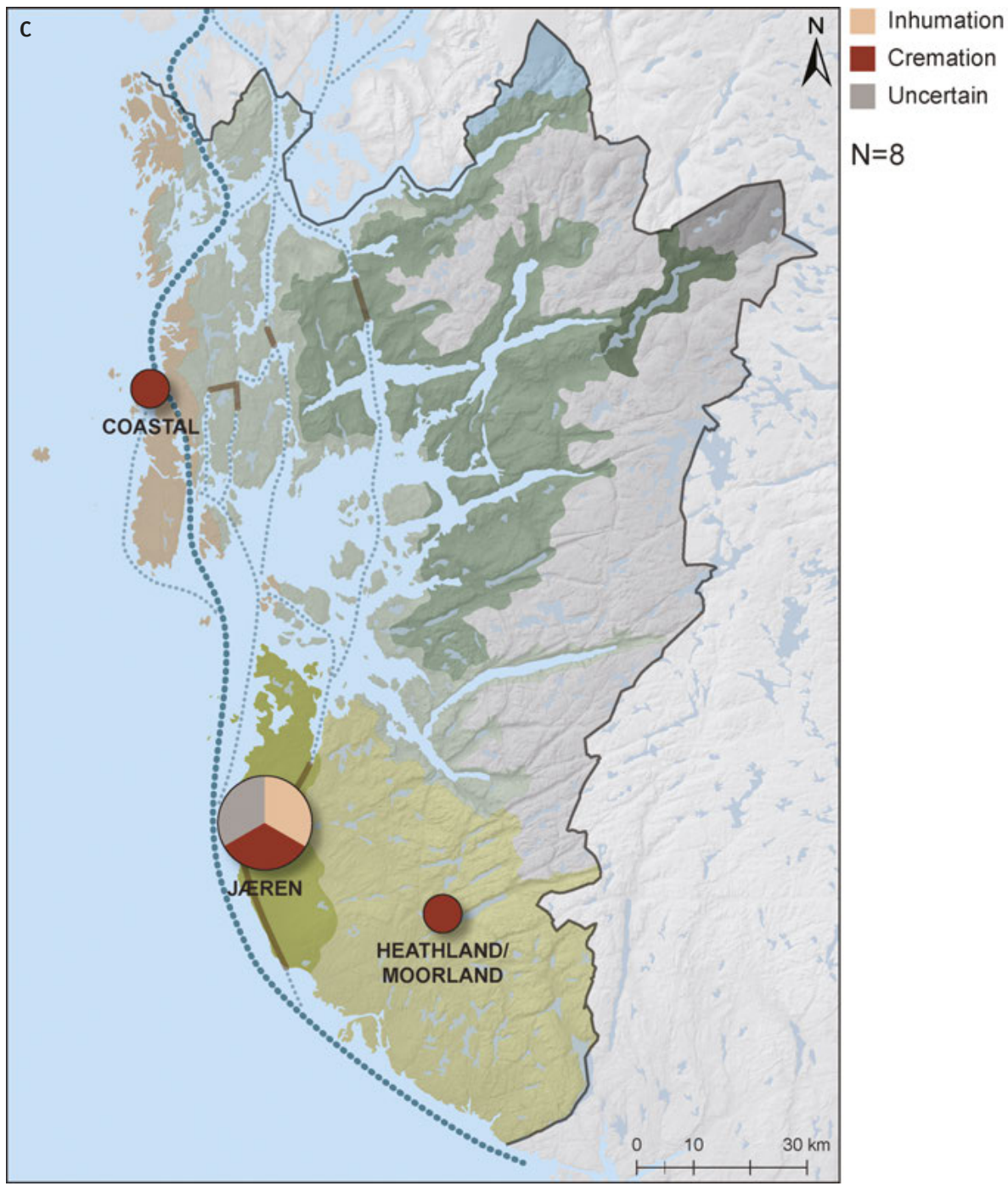

Fig. 2.10c

mythological references, Frankish military ideals, and the novelty of the custom (Braathen 1989; Jørgensen 1991; Meling 2014). The distribution of brooches thus follows elite structures rather than broader social groups with the participation of a larger fraction of the population. On a Scandinavian scale, Røstad (2016a:308-10) argues that the early Merovingian period brooches demonstrate a shift from negotiation of multiple levels of identity to the articulation of superregional affiliation. Though conical brooches have a general distribution overlapping roughly with the territory of modern Norway, there are still spatially structured differences when 
the brooches of Merovingian phases 2 and 3 are brought into consideration and the scale reduced. This is evident in the variety of brooches and particularly the cluster of disc-on-bow brooches at Jæren. The cemetery at Ferkingstad is also notable for its bird fibula and other brooches.

The last decades of the 8th century form a transition between the final Merovingian phase and the initial period of the Viking Age. In this period, on the threshold of the Viking expansion, two ship burials add to the characteristics of Karmsund. The eldest, the Storhaug burial, is located approximately $3 \mathrm{~km}$ north of Avaldsnes and contained a large rowing ship, a horse, gaming pieces, and a gold arm-ring in addition to other objects. The burial is dated to AD 779 (Bonde and Stylegar 2009:159) and has been argued to constitute evidence of kingship in the Avaldsnes area. Another ship, 10-15 years younger and slightly smaller, was buried in Grønhaug, located between the Storhaug burial and the Avaldsnes settlement (Opedal 2010:112-13). Meling (2014) suggests that burials with horses and equestrian equipment are evidence for an alliance with the ruler buried in similar fashion in Storhaug, thus connecting the Karmsund to the mainland. Brooches are not found in these ship burials or burials in their proximity, although other nonmonumental graves or stray finds from obliterated graves dating to the Merovingian or Viking periods have been documented at Avaldsnes (Østmo and Bauer 2018a).

In conclusion, burials with brooches seem to represent a smaller segment of the population. Jæren and Karmsund are the only sub-regions that may be delineated from the burials with brooches, here supported by stray finds and elite burials with horses or equestrian equipment. Jæren in this period is also distinguished by more types and exclusive types of brooches; the two conical brooches at Tau may form an outer perimeter of this sub-region, in which the burials with brooches roughly correlate with the elite burials. The burials with brooches at Karmøy and the northern part of the outer fjords are located at strategic positions along the sailing route. Apart from the horse included in the richly furnished ship burial at Storhaug by the Karmsund strait, the burials with brooches do not overlap with the burials with horses in this region.

\subsubsection{Viking Age c. 750/775-1000}

After the scarce distribution of burials and brooches in the Merovingian Period, there are marked shifts in the distribution of Viking Age brooches. Firstly, the distribution is more widespread and numerous compared to the previous period, signifying that the practice of depositing brooches in burials had become accessible and desirable for a larger fraction of the population. Secondly, the brooch corpus consists of several types and subtypes providing possibilities for articulating differences or similarities between sub-regions; they also illustrate chronological changes within different landscapes (Figs. 2.11, 2.12, particularly 2.12e). Insular imports, 

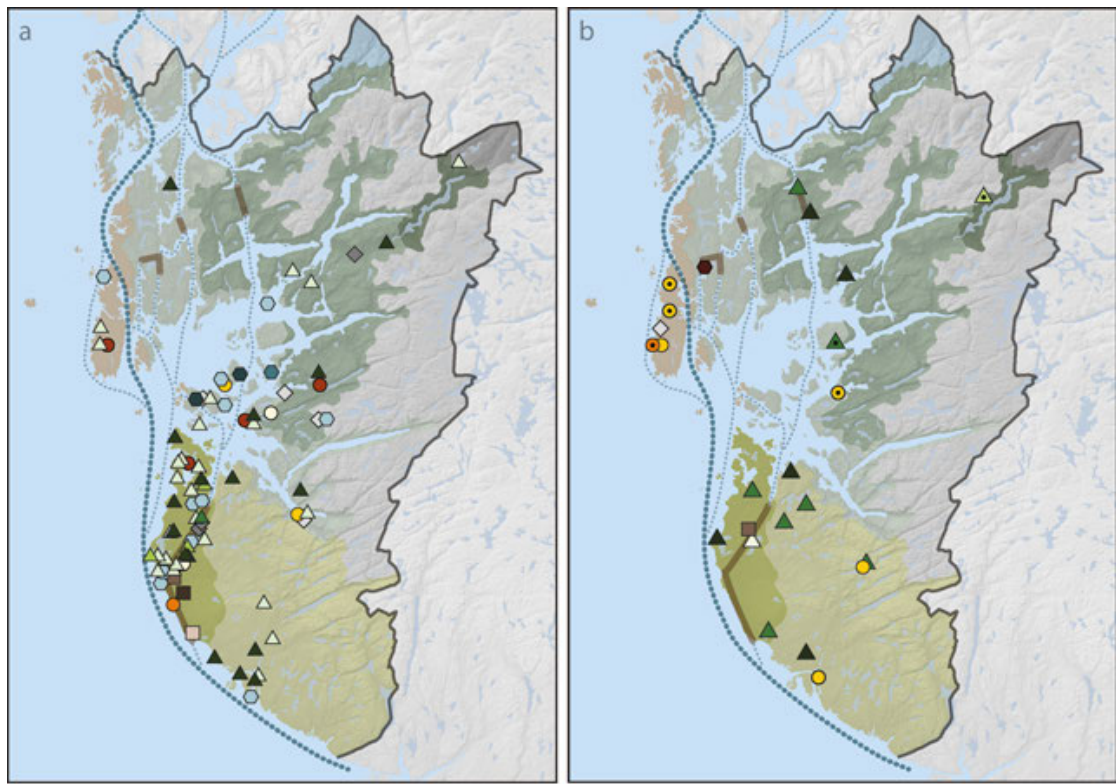

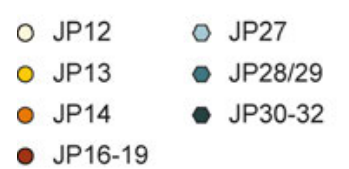

- JP16-19

$\triangle \mathrm{JP} 33 / 37$

JP23

- JP25

- JP25/26

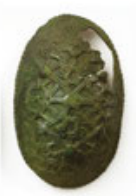

B2634

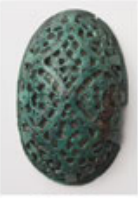

S2852 $\triangle \mathrm{JP} 42$

$\Delta$ JP45/46

A JP51

$N=78$

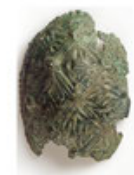

B2711

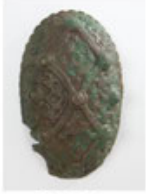

S6888a $\diamond$ Oval brooch, unspecified

$\checkmark$ Double shelled, unspecified
O IA
- IE (lok)
$\triangle$ III unspecified
$\triangle$ IIIA
$\triangle$ IIIB
- II $\Delta$ IIIC unspecified
- Stray find
$\diamond$ Penannular

IV

\section{$\mathrm{N}=24$}

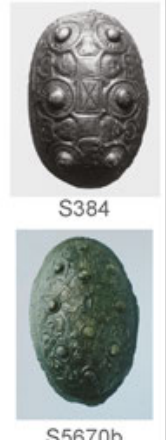

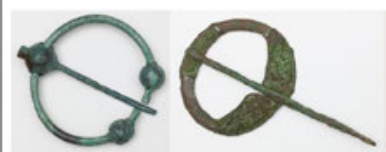

S9278a

S4165n

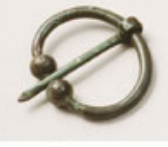

S2834a

Fig. 2.11a-b: Distribution of Viking Age brooches: (a) oval brooches, (b) penannular brooches, (c) imported/transformed brooches, equal-armed brooches etc. Illustrative examples: Oval brooches: B2634 JP46, B2711 JP25, S384 JP16-19, S2852 JP42, S6888a JP33/37, S5670b JP27. Penannular brooches: S9278a IIIB, S4165n IA (lok), S2834a IIIC. Other types: S3456/S2562c Trefoil Rogalandstype, B2561/S3258c Insular import, B4233bb/S11240/S12295 Equal-armed Rogalandstype. Landscape districts after Puschmann (2005)/NIBIO. Illustration: M. Østmo, I. T. Bøckman, MCH. 


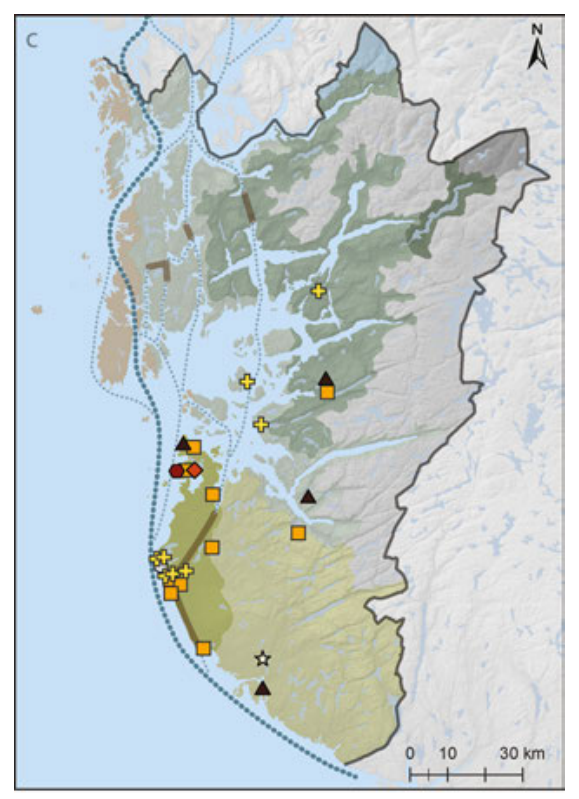
Frankish
- Ringed pin
↔ Insular, transformed
A Trefoil
$\square$ Equal armed
$\diamond$ Rectangular $\quad$ Brooch, unspecifiec

$\mathrm{N}=26$

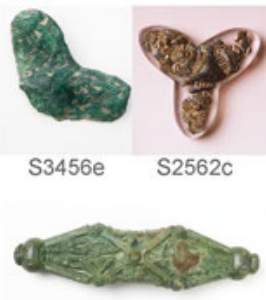

S12295a

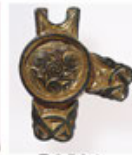

B2561

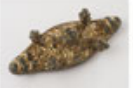

S11240

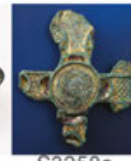

S3258C

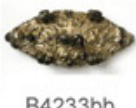

Fig. 2.11c 


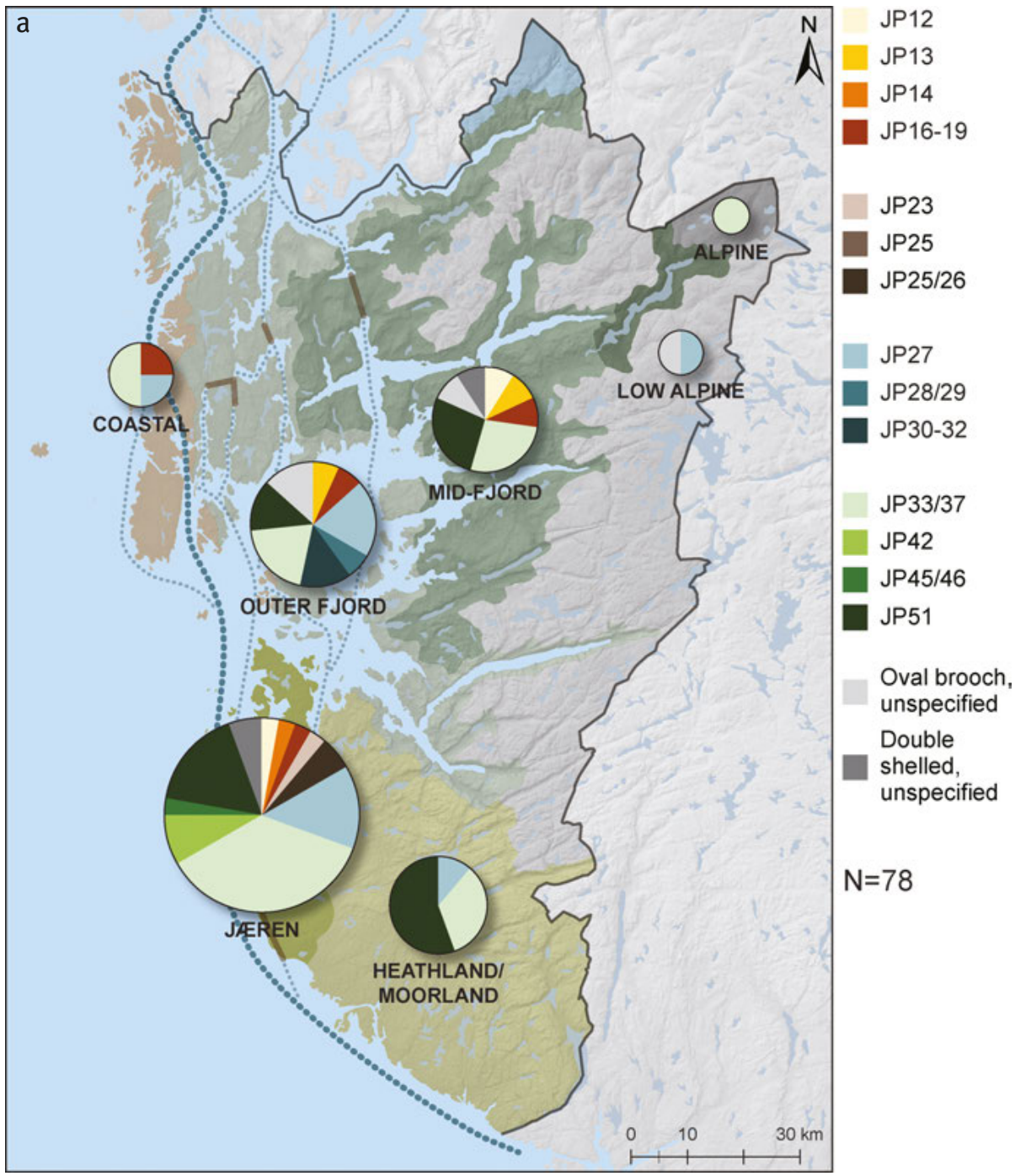

Fig. 2.12a: Statistical illustration of the spatial distribution of (a) oval brooches, (b) penannular brooches, (c) equal-armed brooches, transformed imports, and other brooch forms, (d) treatment of the body, and (e) timeframe within the Viking Age. Landscape districts after Puschmann (2005)/ NIBIO. Illustration: M. Østmo, I. T. Bøckman, MCH.

mainly various copper alloy/gilded fittings remade into brooches or pendants, underline the impact of connections with the British Isles (Fig. 2.11b). Finally, while some areas remain 'central' through all the chronological phases of this study, a shift in gravity for the dispersal of brooches may signify some form of change in the spatial dimension of sub-regions, or the formation of new sub-regions. 


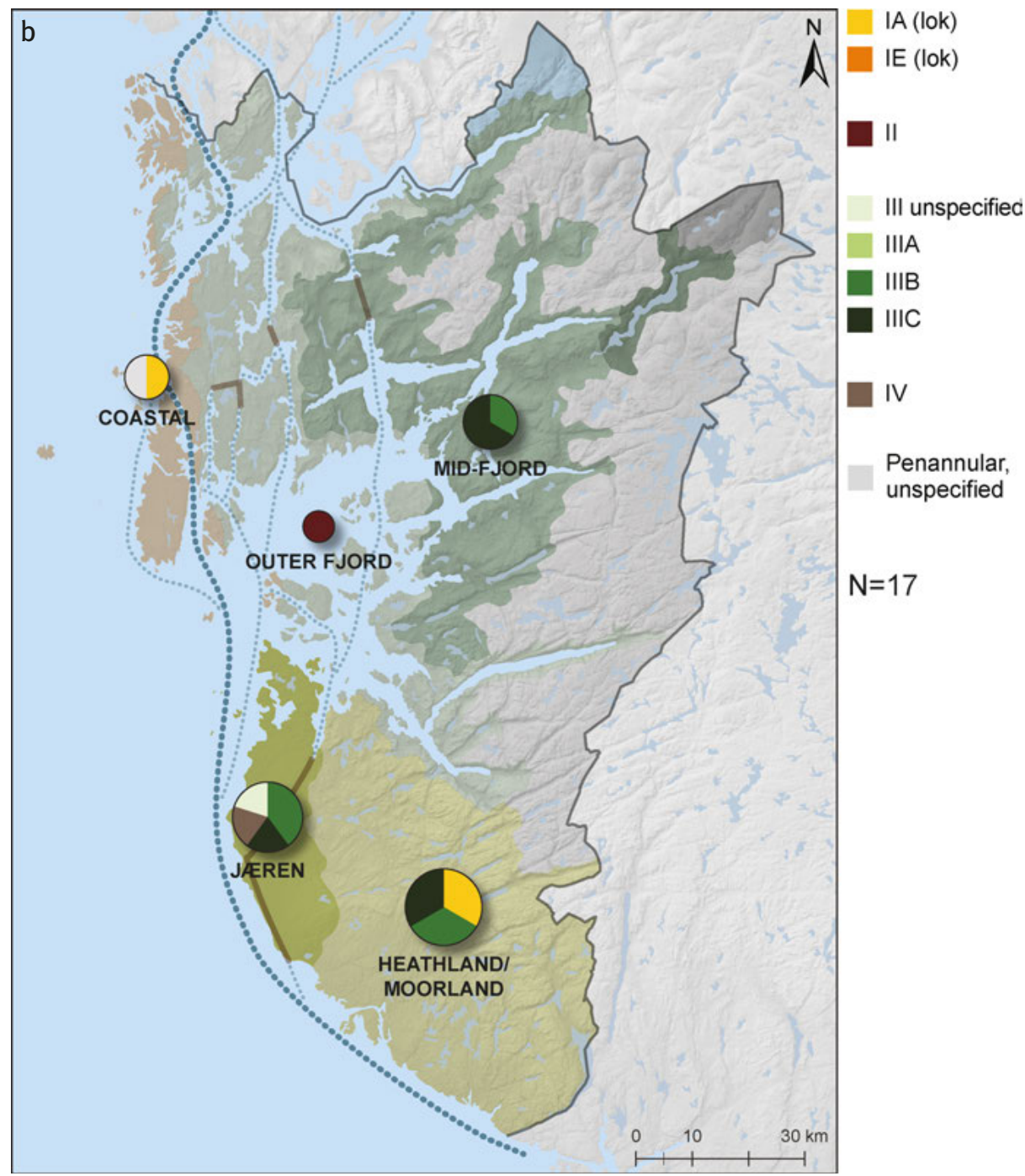

Fig. 2.12b

The distribution of brooches demonstrates that Jæren is characterised by a higher concentration of brooches and higher diversity of brooch types than the neighbouring areas. The following are particular to Jæren: oval brooches of type JP14, JP 42 and 45/ 46, penannular brooches of type IV, equal-armed brooches of type JP60, JP63, and equal-armed type Rogalandsgruppen. Not included in this distribution or analysis is another specimen of the Rogalandsgruppe (S12589), recently uncovered at Karmøy through metal-detecting. While not exclusive to Jæren, their tendency to cluster at Jæren is not diminished. These equal-armed brooches are generally of high artistic 


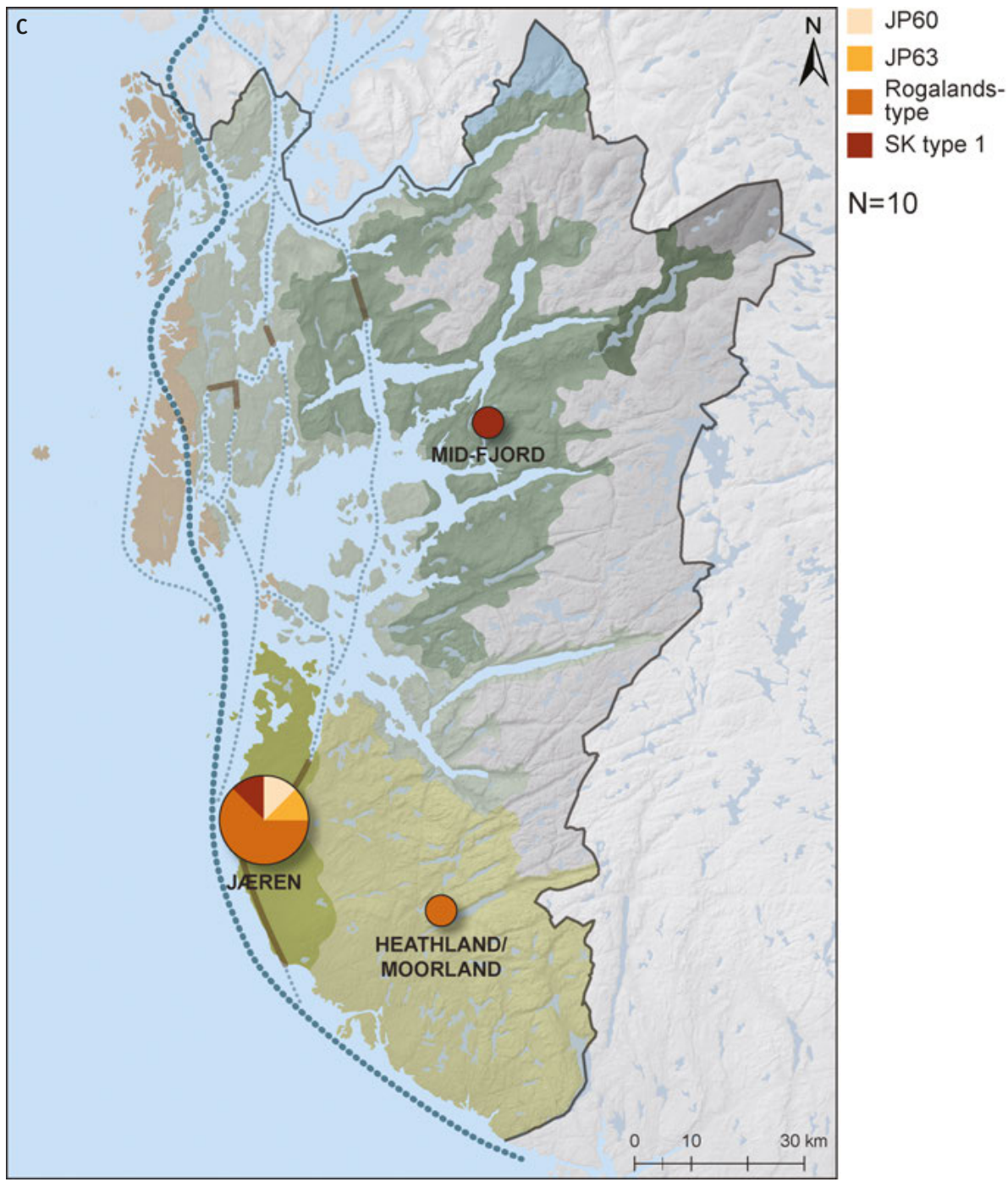

Fig. 2.12c

quality. Similarly, the JP 42 oval brooches display artistic and technical supremacy compared to many other mass-produced sub-types (Petersen 1928:44-6). High-quality goldsmith work seems to be in circulation particularly at Jæren; a pair of JP42 oval brooches are found by Tinghaug and in the burial of the Gausel Queen, which also comprised several insular finds (Bakka 1993; Børsheim, et al. 2002:166-7; Hauken 2014:150). Insular references are also seen in the many imported fittings transformed into brooches, mainly located in the sub-region of northern Jæren and the Ryfylke islands, or generally south of the Boknafjord. 


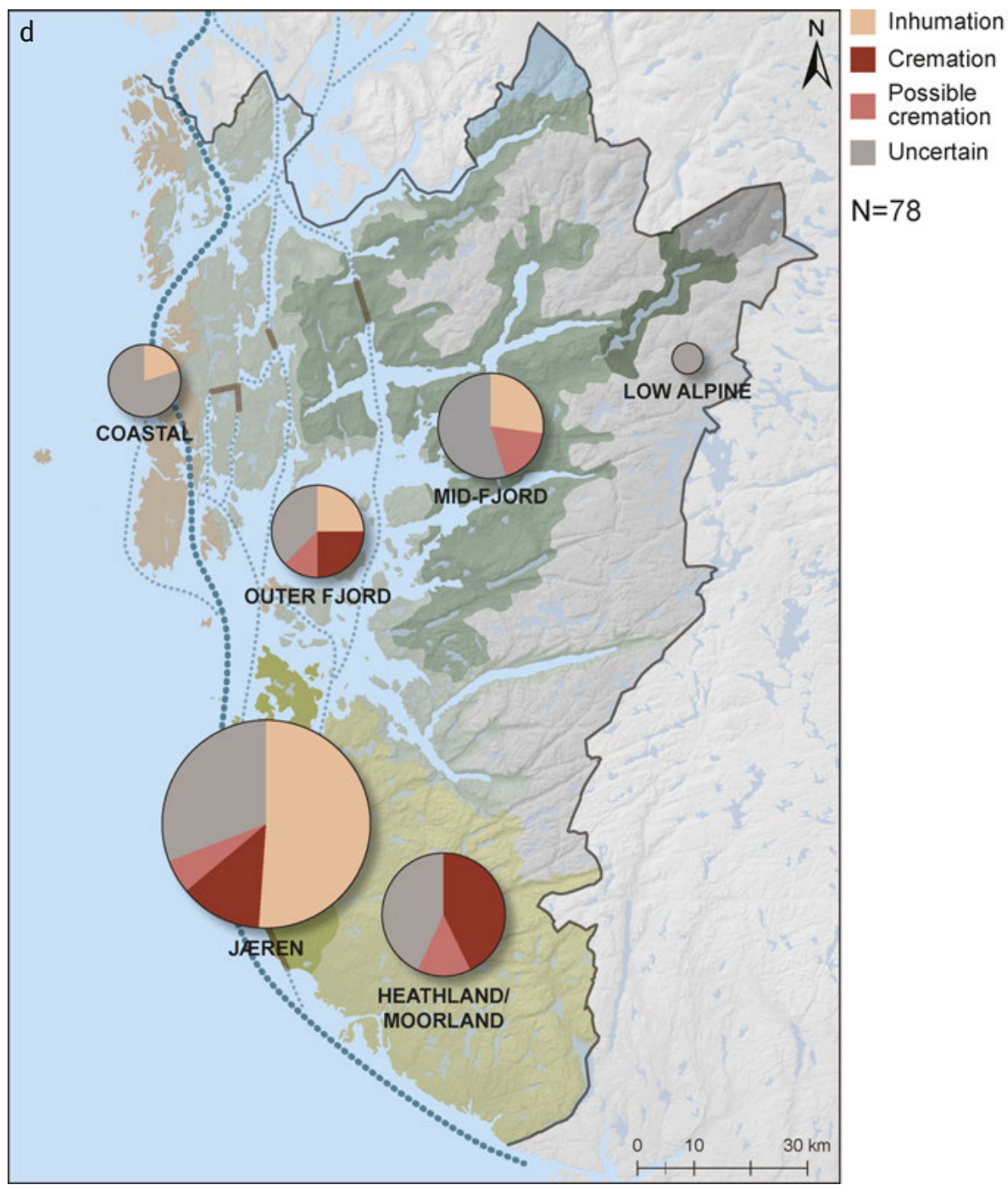

Fig. 2.12d

There is a change in Jæren's characteristics in the Viking Age. The high frequency of burials with brooches at the beach cemeteries at Jæren, characteristic of the late Roman and Migration periods, seem to decline in the Viking Age. The prime example is the vast cemetery at Kvassheim where 126 out of 255 burials have been excavated, of which only one with certainty dates to the Viking Age, and one likely to the late Iron Age (Lillehammer 1996:25, 182, 187).

The Ryfylke islands in the outer fjord landscape were void of brooches in the Merovingian period, but now see a marked increase. In fact, the brooches found 


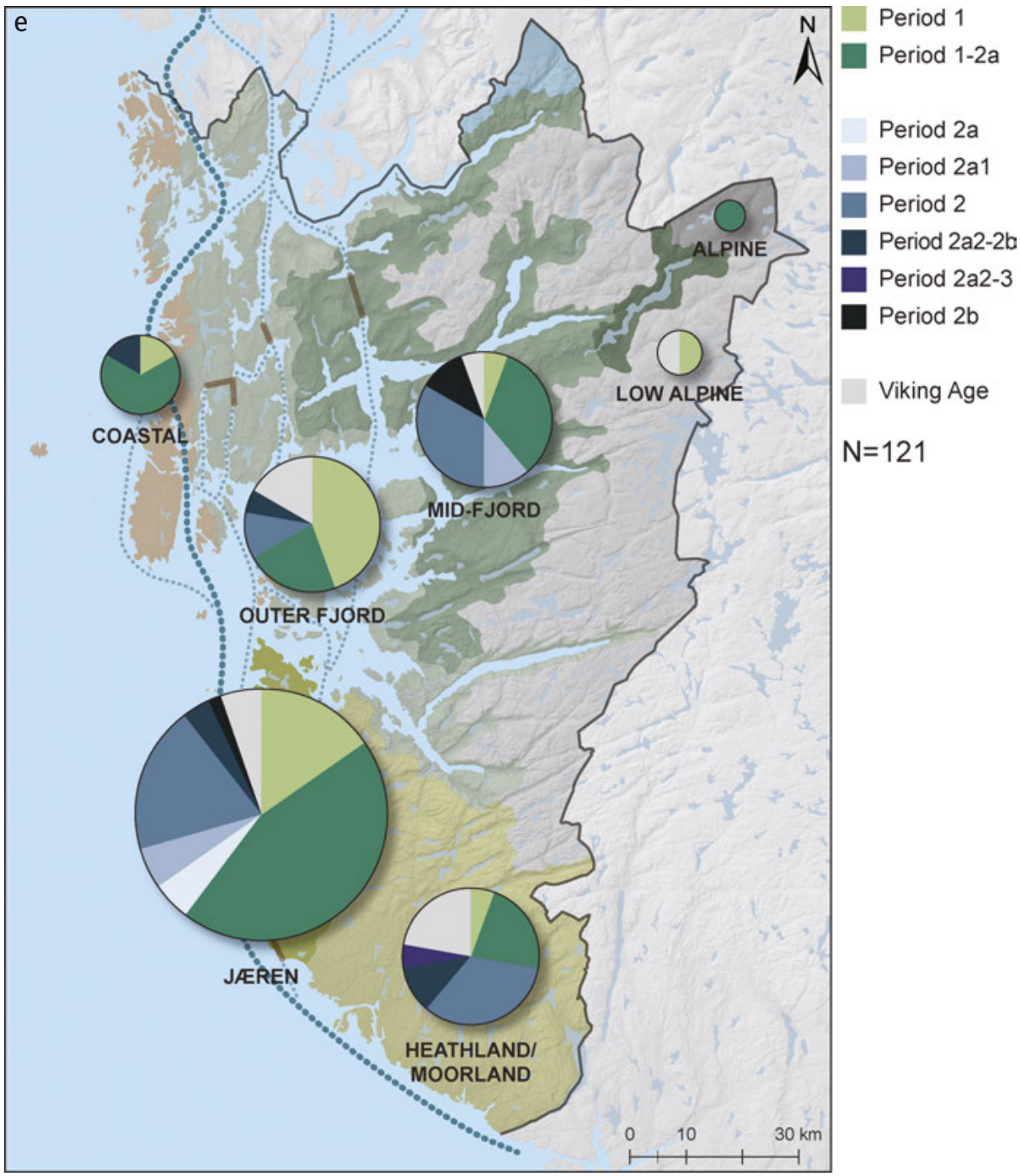

Fig. 2.12e

there and in the southern part of the outer fjord district resemble the ones at Jæren. The burials with brooches at Jæren are mostly dated pre-10th century, though a few have wide date frames reaching into the 10th century (Fig. 2.12e). This prevalence of early burials is observed also around the Ryfylke islands, though the challenge of wide dating frames is more overt here. Both areas also have some cremation burials, though inhumation is prevalent. Penannular brooches are also found at Jæren, indicating participation in elite networks, as will be addressed in greater detail below (Glørstad 2010; Glørstad 2012:255-9; Hauken 2014). 
The outer coast and the outer fjord districts north of the Boknafjord are not clearly distinguished from each other. Here, there are burials with oval brooches, but they are not as frequent or as varied in subtypes as south of the Boknafjord (Figs. 2.11, 2.12). The oval brooches all date to the early Viking Age, except one JP51 brooch with a wide timeframe reaching into 10th century. The outer coast and fjords north of Boknafjord are otherwise characterised most by the use of penannular brooches. Because the omission of stray finds has strongly affected the distribution, these are included in the map, but not in other analyses (Fig. 2.11). Several locally produced brooches of insular types are located in the south-western part of Karmøy. A rare brooch of type IIIA of high quality and with a visual likeness to Irish silver brooches was uncovered at Uvik near Avaldsnes. Its quality and location have been suggested to reflect a high-ranking political position within the royal network of Harald Fairhair and his descendants (Glørstad 2010:255). Other penannular brooches are found on strategic farms where the routes of communication could be controlled.

Contrary to the other sub-regions, the burials in the heathland/moorlands have a larger number of late brooches than early ones, and none of the high-quality pieces or the insular transformed brooches that are found at Jæren. Penannular brooches are indicative of the sub-region's connection to the elite networks, while the other burials with brooches contribute to setting the sub-region apart from the others. Practices such as cremation also contribute to this differentiation.

In several sub-regions, the practice of reusing older monuments is present, at a frequency remaining at about 10\% at Jæren and the middle fjords, $15 \%$ in the heathland/moorland. Otherwise, the tendency is declining (Tab. 2.5).

Tab. 2.5: Overview of the frequency of singular use versus reuse of monuments in the Viking Age. See Tab. 2.3 for general comments.

\begin{tabular}{lcccc}
\hline $\begin{array}{l}\text { landscape } \\
\text { district }\end{array}$ & $\begin{array}{r}\text { Only known grave } \\
\text { in monument }\end{array}$ & $\begin{array}{r}\text { Primary grave in later } \\
\text { reused monument }\end{array}$ & $\begin{array}{r}\text { Secondary burial in } \\
\text { reused monument }\end{array}$ \\
\hline Low alpine & $\mathrm{N}=2$ & 1 & & \\
\hline High alpine & $\mathrm{N}=1$ & 15 & 1 & 3 \\
\hline $\begin{array}{l}\text { Heathlands/ } \\
\text { Moorlands }\end{array}$ & $\mathrm{N}=18$ & 52 & & \\
\hline Jæren & $\mathrm{N}=58$ & 6 & 1 & 1 \\
\hline Outer coast & $\mathrm{N}=6$ & 16 & & 2 \\
\hline Outer fjords & $\mathrm{N}=18$ & 16 & & \\
\hline Mid fjords & $\mathrm{N}=18$ & & & \\
\hline
\end{tabular}


In conclusion, with a shift of gravity and extent in the distribution of brooches, the sub-region of Jæren has departed from the trends seen in previous periods. It is still marked by numerous brooches, of which several are of high quality and some are found only at Jæren. Increased similarities with neighbouring landscapes and a concurrent spatial shift of gravity towards northern Jæren could signify a closer integration of Jæren with the Boknafjord basin. A new sub-region could comprise northern Jæren and the Ryfylke islands and the southern part of the middle and outer fjord districts. Insular imports transformed into brooches are also found within this expanded Jæren sub-region.

The heathland/moorland has some of the same brooches as at Jæren, but generally not those of the highest quality. A tendency toward brooches of a slightly later timeframe is observed. The heathland/moorland areas display a much simpler combination of types of brooches, and cremation is more prevalent here compared to other regions, thus forming a distinct sub-region in the Viking Age. A few burials with oval brooches are found by Karmsund along the outer coast, some of which are relatively early. One of these contained a boat, a horse, a dog, and gaming pieces, all indicative of the elite strata (Opedal 2010:286-7). Most of all, this subregion is distinguished by the highly political symbols of the penannular brooches. Generally, the northern part of the outer fjord districts has very few finds other than a few penannular brooches and oval brooches, and seems to constitute more of a periphery to the Karmsund/outer coast region.

\subsection{Sub-regional trajectories}

In the analyses of intra-regional diversity, distribution maps displaying the location of brooch types as well as the statistical frequencies of brooches and practices bound to different landscapes have served to identify sub-regions. The boundaries and differences between the sub-regions are not clearly delimited or absolute; rather, the analyses serve to identify core-areas defined by similarities. This section provides a rough sketch of their general development, and addresses how they relate to each other and whether changes in these relations may reflect different socio-political processes of integration or distinction. The sub-regions of Jæren and the outer coast/Karmsund remain defined throughout the period of study, though they change in extent. Other sub-regions within the fjord settlements and the heathland/moorland are less constant, forming defined sub-regions in some periods, becoming more integrated with neighbouring sub-regions in other periods. The brief account of the different trajectories follows a spatial structure: (1) the outer coast/ Karmsund, (2) Jæren, (3) the fjord settlement districts, and (4) the heathland/moorland district. 


\subsubsection{Karmsund on the outer coast}

The outer coastal landscape is characterised by a near absence of burials with brooches following the establishment and consolidation of a central seat of power at Avaldsnes in the 3rd century. This trait becomes most apparent with the absolute absence of cruciform brooches in the Migration Period. The majority of the burials containing gold and imported vessels date to the late Roman Period, in the initial phase of Avaldsnes as a place of power. Such investments seem not to have been needed in the following centuries, when the monumental architecture of Avaldsnes demonstrates the site's importance. With the exception of the hall building that cannot be traced beyond the early 5th century, the architecture of the settlement remains stable until the end of the 6th century when the boathouses and longhouse fall into disuse (Østmo and Bauer 2018b). The northern part of the outer fjord district demonstrates the same low frequency of burials with brooches. The centre at Bjoafjord has been argued to be closely interconnected with Avaldsnes, and Reiersen argues that they both lose their significance at about the same time (Reiersen 2017:261). It should be noted that Reiersen (2017:252-5) argues for a decline at Avaldsnes occurring in the 5th century based mainly on the disuse of the hall, the less visible location of the later longhouse, a decline in wealthy burials, and the downscaling of the boathouses. However, his arguments depend on the preliminary interpretations presented in the field report (Bauer and Østmo 2013). Adjustments in the interpretation of the boathouse construction have since led Bauer (2018:188) to moderate this preliminary downscaling. Combined with the continuous agricultural activities (Bauer and Østmo 2018; Østmo 2018), the present author has argued for continuation up to AD 600 (Østmo and Bauer 2018b).

In the early 7 th century, a palisade was constructed towards the strait. It delimited an area designated for treatment and storage of food, particularly cereal. This storage/processing area was in use throughout the Merovingian and Viking periods, demonstrating continuity at the settlement despite the lack of known dwellings dating to the Merovingian period. A monumental mound with no recognised burial, Salhushaugen, was built immediately north of Avaldsnes in the late 6th or early 7th century, demonstrating power at a time when monumental burial mounds were particularly rare (Opedal 2010:51). In the 8th century, a group of burials with brooches is located at Ferkingstad, south-west at Karmøy. In near proximity at Nes, a large boathouse for a ship dated AD 640-800 indicates an investment in control of the seas west of Karmøy (Bauer 2018; Opedal 2010). The palisade at Avaldsnes and the ship burials north of Avaldsnes underline an uppermost elite in the 7th century and an orientation towards the sea by the northern Karmsund in the 8th century. The brooches in the northern outer fjords and the outer coast are quite similar, with the exception of the rare bird-shaped brooch. A political alliance connected to the ruler buried in Storhaug is suggested based on burials with brooches as well as 
horses and equestrian equipment, forming a semi-circle around Karmøy and parts of the northern outer coast (Meling 2014; see Fig. 2.9b). This could also lend support to the increased integration of these landscapes in this period.

In the Viking period, there are a few burials with oval brooches, but only of the most generic types at the outer coast and the outer fjord areas, north of Boknafjorden. The distribution of penannular brooches seems to be linked to an elite network involving Avaldsnes and the political alliances connected to Harald Fairhair. Based on similarities in the selection of brooches and practices, the outer coast and the outer fjord district north of the Boknafjord seem integrated in this period. The political alliance demonstrated by Glørstad (2012) on the basis of the distribution of penannular brooches shows connections not only within the northern part of the study area, but also at Jæren, as in the previous period. The political structure, by this point, is seemingly not rooted in the landscapes and local practices.

\subsubsection{Jæren}

Jæren displays quite different characteristics compared to Karmøy and the outer coast in the late Roman and Migration periods. At this time, Jæren is characterised by a preponderance of elite centres or milieus located within short distances from each other and by copious burials with brooches at the beach cemeteries and further inland on arable land. The elite milieu referred to as the Tinghaug complex, situated on the central farms Anda, Tu, and Hauge, serves to exemplify the plurality of socio-political centres implied by the existence of elite milieus. Particularly from the Migration Period onwards these elites seem to be closely associated with the production of high-quality goldsmith craft, resulting in several unique pieces and local brooch types. In fact, the production and circulation of these high-quality relief brooches have been taken as signifying an elite alliance, with Tinghaug as its centre (Reiersen 2017:323). Richly furnished burials such as Krosshaug with its high-quality brooches and dress accessories have been interpreted as a local/regional chieftain (Magnus 1975) or a cultic leader (Sundqvist 2014). The plurality of elite milieus and centres (Reiersen 2017) fits well with the model describe above, in which wealthy burials indicate that the elites are still using burials to legitimate their power. The politicised use of brooches contributes to the formation of a subregional ideal, and their extensive use becomes a local particularisation (Gosden 2005; Witcher 2017).

Another trait that characterises Jæren is the presence of several courtyard sites, which are assumed to relate to a juridical structure of local or regional assemblies (Brink et al. 2011; Storli 2010). Iversen (2018:729) interprets the courtyard sites predominantly as thing-assembly places at different levels, but also multifunctional in that they also performed cultic and military functions. In addition, Sindbæk (2008b) argues that local or regional markets at the thing-assemblies created a 
social arena through which material culture was circulated and traded, contributing to the development of the regionality observed in various forms of material culture. In a recent study, Iversen (2018:745) has published additional radiocarbon dates for courtyard sites in Rogaland, demonstrating their continued use up to the 8th century, thus indicating a relatively long duration for the juridical networks these sites represent. Their proximity to each other may mean that the different courtyards were associated with different administrative levels; alternatively, it could mean that each courtyard served only a small territorial jurisdiction. Although courtyard sites and thing assemblies reflect communal institutions and principles, society nevertheless was stratified, as may be seen in both quantitative and qualitative differences within the cemeteries and burials. The wide range of elite milieus also implies a stratified society in which local elites were still competing for control and power.

In the late Roman period, Jæren is distinguished as a sub-region on its own. In the Migration Period, it is possible that the heathland/moorland areas are assimilated with the practices at Jæren, possibly becoming more closely integrated, though still with fewer burials and fewer brooch types.

The general decline in burials in the 6th century appears most dramatically at Jæren as compared to the previous period, when burials were abundant (compare Figs. 2.6a-c and 2.9a). Still, the practice is upheld, with higher concentrations of brooches at the beaches and centrally at Jæren. The visually distinctive disc-on-bow brooches that have been related to female genealogy (Røstad and Glørstad 2015) form one significant cluster at Jæren. Three of the brooches were combined with large collections of beads, several imported from the eastern Mediterranean or the Black Sea area and seemingly express a female ideal of the upper echelon of society; one of these was buried in a pre-existing cairn at the beach cemetery at Hå (Myhre 2013:292). The lacuna between the youngest Migration Period burials in c. AD 550 and the 8thcentury disc-on-bow burials have been related to a general decline following climatic events or plague in the late 6th century. However, as at Avaldsnes where no buildings or burials date to the 7th century, excavation of agricultural remains indicates continuity at Avaldsnes and at various places in Jæren, which Myhre (2013:295-7) characterises as a restructuring of the landscape rather than a total collapse. The increasing number of conical brooches from the initial phase of the Merovingian Period may bring more nuances to this discussion of decline or restructuring of landscapes and practices. The burials with horses and equestrian equipment also indicate a political network connecting Jæren to Avaldsnes/Karmsund from the 8th century, oriented around the ruler interred in the Storhaug ship burial (Fig. 2.9b). This political network seems to cut across sub-regions, not affecting the sub-regional social networks. In the Merovingian Period, Jæren seems to be defined as its own sub-region, the heathland/ moorland no longer closely integrated.

In the Viking Age, there is a shift of gravity towards northern Jæren, possibly related to a maritime focus on harbour areas on the eastern and western side of the 
Stavanger Peninsula, where many boathouses have been registered (Fig. 2.13). Related to this shift, burials with brooches very similar to those on Jæren are at this time found on the Ryfylke islands and the fjord settlements south of the Boknafjord. This signifies a decreasing focus on local differences and a closer integration of the

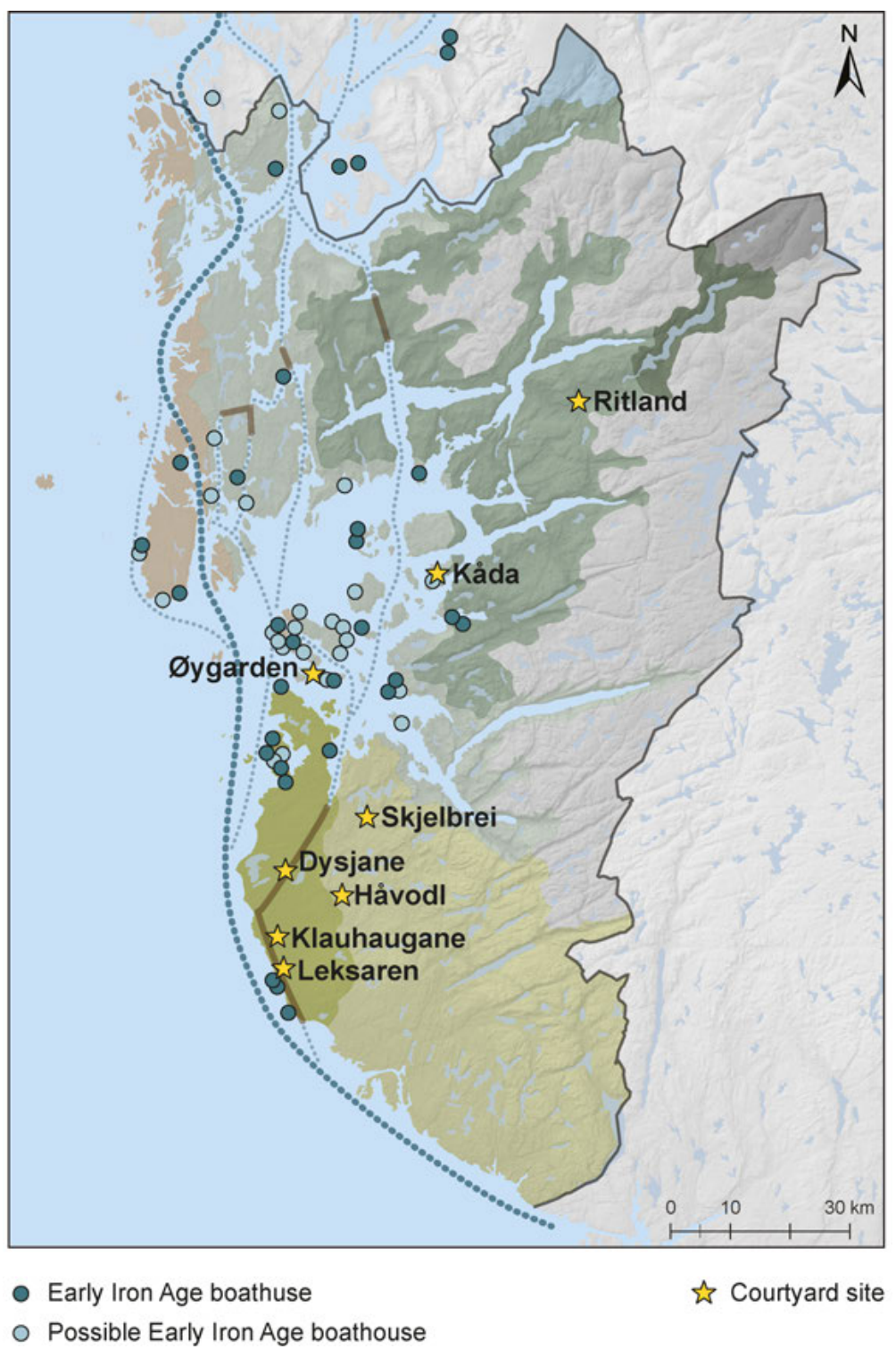

Fig. 2.13: Distribution maps of courtyard sites in Rogaland (after Iversen 2018:fig. 26.2) and known boathouses from Rogaland (after Bauer 2018:fig. 10.7). Illustration: M. Østmo, I. T. Bøckman, MCH. 
landscapes south of the Boknafjord. The distribution of brooches of insular origin, mostly transformed fittings of various forms, follow roughly the same patterns of distribution. The presence of courtyard sites within the same landscapes should be noted. While the courtyard sites have not been dated later than the 8th century (Iversen 2018), they may reflect social and communal networks that were still upheld, despite a change in the location for thing assemblies. Alternatively, centralisation processes within the juridical organisation could have led to new arenas for the circulation of ideas and materialities, lessening the articulation of local particularities.

\subsubsection{The Fjord districts}

The fjord settlements display a non-consistent distribution of burials with brooches. Such burials are found in these landscapes throughout the period of study, but they do not form clusters as stable as those seen at Jæren, displaying instead greater tendencies for short-lived distribution patterns. Within the same landscapes, elite milieus have been identified, but are generally concentrated in fewer burials and oriented towards strategic locations in relation to the sailing routes, for example at Innbjoa or Etne (Reiersen 2017:256-8). In Etne there are also large cemeteries, but quite differently structured compared to the beach cemeteries, with more focus on for instance weapon burials, making this centre less pertinent to the present study. In some periods, burials in the fjord districts, such as those containing horses/ equestrian equipment or penannular brooches indicate participation in networks with centres outside the fjord districts (e.g. Meling 2014).

In the late Roman Period, the middle fjord area is distinguished from both Jæren and the outer fjord based on brooch composition and more frequent use of cremation. In the Migration Period, the middle fjords appear to be integrated with the low alpine areas, as they share the distribution of Byrkje cruciform brooches. In the Merovingian Period, except for two conical brooches, these areas are empty. In the Viking Age, the inner, middle, and outer fjords south of the Boknafjord all appear to be integrated with each other, focusing on the Boknafjord basin and northern Jæren.

\subsubsection{The heathland/moorland}

In C3, the heathland/moorland is quite distinct from Jæren, practicing cremation instead of inhumation and constructing round monuments instead of oval, though sharing several brooch types. In the Migration Period, this opposition is decreased; the heathland/moorland assimilated towards the practices of Jæren. In the Merovingian Period, only one brooch exists in this landscape, but also points towards Jæren, whereas in the Viking Period, new clusters of brooches appear north of Eigersund. The oval brooch types have a tendency to be slightly younger here 
than in other landscapes, and the practice of cremation is prevalent at a time when all the rest of the study area practiced mainly inhumation. From C3, a small lacuna may be observed at the transition to the neighbouring county, Vest-Agder, likely due to the location falling between centres.

\subsection{Changing sub-regions, changing political landscapes?}

The diversity of mortuary practices and selective use of brooches accounted for in the previous section demonstrates the contrasting tendencies of shared traits across landscapes combined with local particularities. These local particularities serve to identify sub-regions through a preference for brooches other than those common to their neighbouring areas, or through different ways of treating the bodies of the dead or constructing monuments. They do not appear as closed regions with clear borders, but rather in combination, along several axes of similarity and difference. In these combinations, it is still possible to identify core areas characterised by internal similarities and outward contrasts. Such core areas or sub-regions may reflect different ways of participating in communication networks, and may relate to shared ways of life or to strategic and politicised practices or materialities.

The following section will explore how these sub-regions relate to sociopolitical structures and change by addressing different explanatory models for interpreting key characteristics of the sub-regions identified in the previous sections.

\subsubsection{Explaining lacunae}

When looking at the distribution map of brooches in periods C3-D2 and particularly the distribution of cruciform brooches, there are areas that appear empty (Figs. 2.4a, 2.6a-c). Some of these vacant areas may be explained by natural predispositions in the terrain, which create peripheries where the living conditions and access to resources change decidedly (Helgesson 2008). Such explanations are particularly relevant for the alpine areas along the south-eastern, eastern, and northeastern borders of the study area. Similar explanations also apply to some parts of the heathland/moorlands landscape region. As demonstrated in Fig. 2.4b, the absence of brooches in Dalane and the outer coast cannot be explained by a general absence of people, graves, and settlements; therefore, explanations must be sought elsewhere (Andersen 1968). The two lacunae may appear similar at first glance, but the distribution of Roman and Migration period elite indicators such as gold, weapons, imported vessels of bronze or glass, underlines the difference between the outer coast and the Dalane lacunae. Apart from a few burials with weapons, Dalane 
lacks burials that would indicate particularly high status. Rather, the distribution of elite indicators is reflective of Dalane's location between centres in Rogaland and the neighbouring Vest-Agder county in the late Roman and Migration periods. The lacuna may therefore represent a transitional zone between these centres.

Such is not the case at Avaldsnes, where massive investments in burials and monuments, the construction of a separate hall building and a boathouse for a large ship all demonstrate power and control over the Karmsund strait from the 3rd century onwards (Tab. 2.1 for more detailed dates). The settlement takes on a structured spatial architecture with zones for dwelling, large infields, a harbour area, and mortuary monuments, as well as a 4th-century longhouse remaining in use until the late 6th century. Several of the burial monuments in the immediate landscape included high status objects such as imported bronzes or objects of gold, clearly contributing to the establishment of an elite. From this initial establishment in the 3rd century to the end of the 6th century, Avaldsnes appears structured and stable, leaving no doubt to its continued centrality throughout these centuries - all of which underscores the apparently mysterious absence of brooches in its surroundings. Two not mutually exclusive explanations may be offered regarding the absence of brooches on the outer coast. First, the burial practices in the area demonstrate a different selection of objects, several of these interred in Bronze Age monuments. Eschewing the use of brooches may be a conscious strategy to emphasise a cultural identity, to signal discernment from surrounding sub-regions wherein this practice is becoming characteristic during C3. Similar mechanisms - what Hedeager terms cultural barriers or resistance - could explain the absence of Roman imports in burials on Jutland in the late Roman and Migration periods as a marker of distinction from neighbouring regions (Hedeager 1992b:192-3; Ringtved 1988).

The second explanation relates to the consolidation of elites and the onset of peer competition. While the settlement of Avaldsnes seems stable from the 3rd to the late 6th century, the high-status burials in the area are, with a few exceptions, predominantly from the late Roman Period. The massive investments of the 3rd century - in the settlement structures, and in burials and monuments at Avaldsnes and in the immediate surroundings - serve the establishment of an elite. As the position of the ruler at Avaldsnes was established and control of the strait secured, the need for ritual activities changed and the number of high-status burials declined. The 4th-century Flaghaug grave 3 with a Westland cauldron and a 5th-6th century weapon burial from an unidentified monument seem to confirm an established position. Other less conspicuous burials have also been uncovered at Avaldsnes; several unexcavated monuments are not particularly monumental. By contrast, the elite burials at Jæren, many with high-quality brooches, were interred throughout the Migration Period. Although the Tinghaug complex may have held a superior position, the simultaneous existence of numerous elite milieus and centres likely created a need for continued manifestations of power and affiliations in their burials, as previously mention with regard to the networks observed in the distribution of 
particular relief brooches (Kristoffersen 2000:190-1). Such explanatory models have previously been argued in contemporary Denmark (Hedeager 1992a, 1992b). In Hedeager's interpretative model, the shift from depositing wealth in burials to ritual depositions was characteristic of the consolidated elite and was interpreted as a centre. By contrast, the regions where power was unstable and demonstration of wealth in burials continued were interpreted as the periphery. In the present study, rather than imposing the roles of centre and periphery, these differences are interpreted as sub-regions that are structured by different principles and follow their own trajectories (see a similar line of argument in Holst 2014), despite their geographical, social, and cultural proximity. This point will be expanded upon below.

\subsubsection{Intra-regional diversity and parallel societal development}

As I have argued and demonstrated in the presentation of the diachronic analyses, the recurring deposition of brooches in burials is a practice most visible in the Jæren sub-region. Already in C3, this tendency was gradually manifesting, especially along the beaches where these brooch-burials are quite characteristic. The burials with brooches seem to have been given special significance within the society that constructed them, as is inferred from the deep-rooted and persisting practice of interring the dead with pairs or sets of brooches. The tendency here is to concentrate these burials in large cemeteries along the beaches with few typically 'male' weapon burials and the recurring uses of oblong/oval monument forms. Moreover, the burials with brooches more often were selected for secondary burials at Jæren compared to other sub-regions; several of the brooches from these are relief brooches of particularly high quality. Through this repeated practice and specific selection of artefacts for the burial contexts, the burials with brooches have served to distinguish Jæren from its adjacent landscapes, and particularly from Avaldsnes and the outer coast. Thus, it seems that the burials with brooches had become a politicised ideal at Jæren already in C3 and persisted throughout the Migration Period. Even the few burials with discon-bow brooches may be referencing this same ideal in the Merovingian Period.

Such differences between neighbouring regions have been demonstrated in Roman Period Denmark as well. Here, rich warrior burials are found in Jutland and rich female burials in Zealand. Assuming that only those bequeathing an inheritance would receive richly furnished burials, these regional differences have been interpreted as reflections of different systems of inheritance (Hedeager 1992b). By this logic, men in Zealand would not leave an inheritance (Hedeager 1992b:133). The many oblong/ovals monuments, both at the beaches and further inland at Jæren, are also relevant with regard to inheritance (see also Gjerpe 2017 for a diversified view on inheritance). Several scholars have addressed the point that oval or oblong mounds (in Norwegian, langhauger) predominantly have been raised over female burials; one suggestion holds that they relate to the passing of land properties 
through women (Lillehammer 1996:23, 2014:24, with further references). Research on the Tinghaug complex convincingly demonstrates that property, inheritance, and power are expressed and legitimised through a group of wealthy female burials with high-quality brooches (Kristoffersen et al. 2014; Magnus 1975, 2014; Sundqvist 2014). It thus seems reasonable that underlying principles such as inheritance structures may have contributed to this difference between Jæren and Karmøy with the outer coast. A relevant parallel may be found in southern Scandinavia, where Holst (2014:180-1) argues that regional variation relates to landscapes being structured predominantly by the principles of either village community or warrior aristocracy. Furthermore, these underlying principles allowed quite divergent socio-political structures to develop within neighbouring regions. The outer coast with the centre at Avaldsnes without burials with brooches, and Jæren with its numerous burials with brooches and elite centres located quite close to each other, could imply parallel socio-political structures developing within different landscapes, as is particularly evident in the 4th-6th centuries.

It should be noted that gendered differences between Jæren and Karmsund are not a novelty of the 4th-6th centuries. As early as Bronze Age period II, monumental mounds containing burials with jewellery were dominant at Jæren, located on moraines and in cultivated landscapes. A new and partly parallel trend of monumental mounds oriented towards the sea and containing weapons developed early in period III at coastal Jæren and along the Karmsund strait (Myhre 1998:196-7). It seems that a male warrior ethos focused on marine activities was developed on the coast as early as the Bronze Age and again in the late Roman and Migration periods, though the centuries in between are unclear due to few burials. The warrior/maritime focus appears in periods characterised by far-reaching networks and communication by sea.

The contrasting jewellery burials at Jæren and the agricultural orientation may be seen as a long-lasting trend, or longue durée. The spatial pattern is not static, as the Jæren beach cemeteries clearly constitute burials with brooches and other jewellery, and not weapons, in the Roman period onwards. The divisions are not absolute in the Roman period, either - one burial with a pair of Niemburger brooches was found on the western coast of Karmøy, whereas the other brooches of this period found along the outer coast do not make up traditional sets of jewellery. Røstad (2016a:359-63) has addressed the presence of brooches in weapon burials and argues that certain clasps or brooches also appear in burials with weapons, but these are generally not of regional character. The very few brooches on the outer coast from the late Roman period onwards are not all weapon burials, but they do not comprise pairs of brooches combined with beads/textile tools as seen in the repeated patterns at Jæren at cemeteries such as Kvassheim (Lillehammer 1996). While non-regional brooches may appear in weapon burials, as argued by Røstad, the occurrence of this combination in larger sets is a particularity of Jæren (Fig. 2.6d). The sub-regional particularities thus may pertain either to the use of certain brooches or to the manner of use or display of the brooches. 
Sindbæk's (2010) theory of thresholds in the dissemination of practices and technologies is relevant for explaining how the use of brooches could become so widespread at Jæren: the dissemination is increased when already practiced by the elite as seen in the Krosshaug burial, as well as by larger communities at the beach cemeteries. Thus ideals and practices are established by attending the same burials and rituals, and then possibly increased and enhanced as those occasions and burials become collective memories. These burials and the people buried there have had a lasting significance for the remaining communities as their mounds or cairns often are chosen for later and repeated use. In contrast, such practices and ideals may not have caught on at Karmøy, where the Longåker burial is the only Roman Period burial with a pair of brooches, and none are known from the Migration Period.

\subsection{3 'Similar difference' and connectivity}

The end of Migration Period and the beginning of the Merovingian Period coincides with the AD 536 climatic event, the aftereffects of the decline of the Western Roman Empire, and the Plague of Justinian (Skre this vol. Ch. 3.5.1). In the burials with brooches, a marked decline may be observed. Though there is a constant flow of foreign objects reaching Scandinavian territories, the scale is quite different from that of the preceding late Roman and Migration period and the following Viking Period (Fig. 2.8; Sindbæk 2017:555-6). A renewed upsurge of connectivity relates to the development of the emporia networks, which through maritime trade and mobility created new forms of economic integration across regions (Sindbæk 2017: 556-7). Within the study area, the significance of the sailing route as a medium for the circulation of artefacts and communication is not new. The orientation towards the sea is particularly clear in the beach cemeteries and in the layout of Avaldsnes and the monuments along the Karmsund Strait. The two ship-burials by the Karmsund Strait in the late 8th century are in themselves a return to an established symbolism and connected to a new elite ideology, observed amongst other places in the ship burial of Sutton Hoo as well as in literary sources (Opedal 2010:69-89).

Following the re-establishment and consolidation of the seat of power at Avaldsnes by help of the ship burials, the transition to the Viking Age displays a reappearance of clusters of burials with brooches, now in all landscape regions. Still, Jæren stands out with the most variation and highest quantity of brooches. There is, however, a geographical change: the centre of gravity is now moved further north, and the Ryfylke islands and the fjord settlements south of the Boknafjord seem to form a more integrated whole. The distribution of late Iron Age boathouses support this spatial focus (Fig. 2.14). The written sources speak of the royal presence at Avaldsnes, but the archaeological evidence for the royal manor at Avaldsnes is limited. The fortified food storage area initiated in the 7th century 
displays intense use up to the early 11th century, but it is uncertain how long the 7 th century palisade remained in function. A 10th-century building of unknown size was raised on a particularly visible location on the central plateau where the late Roman Period hall had lain earlier.

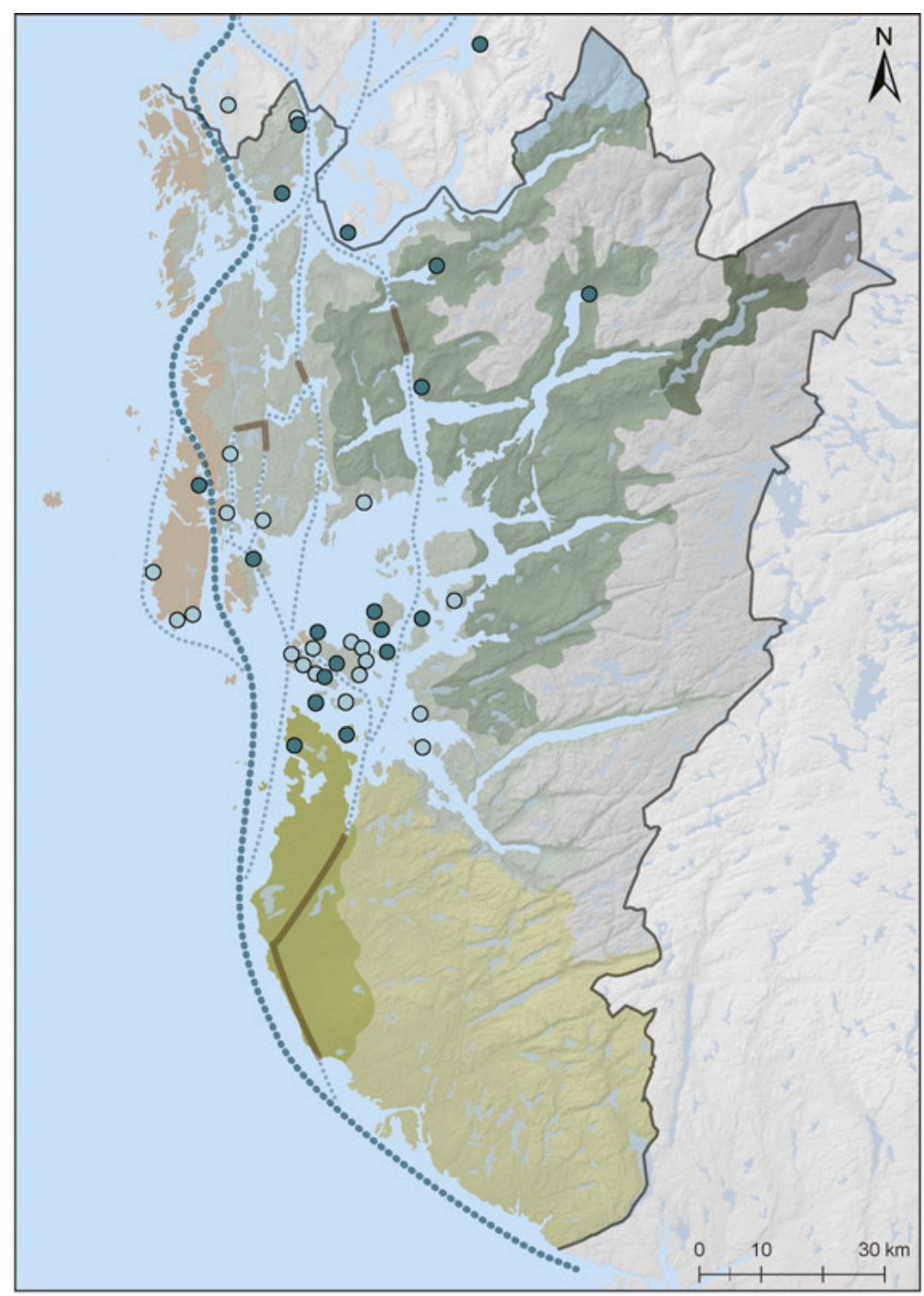

Middle Age boathuse

O Possible Middle Age boathouse

Fig. 2.14: Distribution of known late Iron Age/medieval boathouses in Rogaland (after Bauer 2018: fig. 10.7). Landscape districts after Puschmann (2005). Illustration: I. T. Bøckman, MCH. 
As pointed out by Sindbæk (2017:558-9), the use of sails and navigation techniques increased global interaction within the Viking world, resulting in close transregional contact and establishment of a Scandinavian diaspora maintaining cultural identity and practices, while also assimilating with local culture and participating in political or military campaigns. The large quantities of Viking Age insular import found in south-western Norway indicate the significance of the participation in these networks. The insular finds do however seem to affect two different sociopolitical networks. The first is oriented around penannular brooches the other various forms of copper alloy or gilded fittings transformed into brooches or pendants, becoming part of the dress accessories. The initial use of insular penannular brooches was also as accessories to female dress, constituting material references to the Irish Sea. From AD 850, the penannular brooches are physically and socially transformed, as locally produced penannular brooches now appear in male burials of a certain status. This, argues Glørstad (2012), demonstrates a transformation into a politicised symbol that bore with it the reference to the political alliance around Harald Fairhair and his close connections and political support based in the area of the Irish Sea (Glørstad 2010, 2012:248-9). The distribution of these penannular brooches displays concentrations around Avaldsnes, at Jæren, and along some of the inner fjords. These brooches thus represent an elite network in the form of a political alliance, likely centred on Avaldsnes.

The remaining insular brooches, mostly in the form of transformed fittings, are found mainly in burials south of the Boknafjord, traditionally interpreted as trophies or gifts brought back from Viking Raids (Lillehammer 2014:34). By contrast to the penannular brooches that likely were distributed through the networks connected to Harald Fairhair and his political campaign for kingship (Glørstad 2010:249), the other insular brooches may represent those who were directly involved with the campaigns on the British Isles. A relevant parallel is found in Scania in the late Viking Age, where the distribution of English coins and runestones referring to the campaigns in England indicate different forms of circulation of materialities. In one area, objects are interpreted to have been distributed through the central ruler at Uppåkra; in another area, English coins were located more directly at farms that had no prior magnate status or networks, likely representing those involved in the campaigns (Helgesson 2008). It is possible that the recruitment to ships bound for the British Isles was targeting other existing social networks and that similar processes took place in south-western Norway. The increasing similarities in brooch distribution and mortuary practices on the northern part of Jæren, the Ryfylke islands, and the fjord districts south of the Boknafjord, in correlation with the spatial distribution of the transformed insular fittings, could indicate that these landscapes were becoming increasingly integrated with each other. The mode of circulation of material culture contributes to a common practice, and possibly to a notion of affiliation, both to the insular world 
and to the people in the sub-region using the same type of artefacts. The networks towards the insular world had become a network of affiliation, to use Knappett's (2017) term.

Also recorded in these landscapes are several boathouses (Figs. 2.13 and 2.14), indicating an orientation toward maritime activity and possibly a more organised maritime military structure. Such a connection finds support in the work of Opedal (2016), who argues that the Hafrsfjord area functioned as a maritime base in the Viking Age. The boat-burials at Gausel, alongside the chamber burial of the Gausel Queen, which contained high-quality local jewellery as well as equestrian equipment decorated with insular fittings, are all oriented towards the fjord basin on the eastern side of the Stavanger Peninsula (Bakka 1993; Børsheim et al. 2002). The objects in the burials, their location, and the boats all underline a maritime focus and networks between the insular world and northern Jæren, the Ryfylke Islands, and the fjord districts south of the Boknafjord. The insular connections thus affected networks on different social and spatial scales; the controlled distribution forged political alliances, binding together the social aggregates in the landscapes south of the Boknafjord (Feinman 2017).

\subsection{Concluding remarks}

One issue raised by Hedeager (1992b:208) is that increased diversity in the material culture likely reflects both regional and intra-regional divergences or oppositions. In the analysed material of brooches in burial contexts, two phases are characterised by a brooch material that is complex and numerous, namely the late Roman and Migration periods, and the Viking Age. Theoretical perspectives on past globalisation contribute to explaining why local or regional differences emerge as a response to a contemporary historical context characterised by high interconnectivity. These same two periods, in which the regional variations and geopolitical landscapes are most articulated, namely the Late Roman/Migration period and the Viking age, are characterised by wide-ranging superregional networks through which artefacts and ideas were disseminated. In the discussion of the formation of regions within the study area, elements have been applied of other models targeting the formation of regionalities by the consolidation of elites or the parallel development of principally different socio-political structures in neighbouring landscapes or regions. An eclectic use and combination of these models would seem to lead to a better understanding of the various social mechanisms involved in formation of (sub-)regional differences.

An analysis of spatial and temporal differences in burial practices and use of brooches, in light of the contemporary elite settlement at Avaldsnes, has provided an opportunity to compare the chronological developments within sub-regions with 
the changes in the uppermost elite in order to address a correlation of sub-regional trajectories with ongoing socio-political processes of centralisation or distinction. This approach has also brought the outer coast into the discussion of sub-regions; a singular focus on brooches would have excluded that landscape. Instead, the analyses resulted in the recognition of the outer coast with Karmsund and Jæren as the most clearly defined sub-regions, the former due to its refraining from the use of brooches in the late Roman and Migration periods, the latter for its extensive use of brooches in the same period.

Other sub-regions were identified based on similarities or differences in brooch corpus and in practices. While the outer coast/Karmsund and Jæren remain highly defined throughout the period of study, the degree to which they are integrated with neighbouring regions varies for different times. The outer fjord areas north of the Boknafjord become increasingly integrated with the outer coast/Karmsund through the Migration and Merovingian periods. While the heathland/moorland is clearly distinguished from Jæren in the late Roman Period, this area is assimilated with Jæren during the Migration Period, but appears separated from Jæren in the Viking Age, demonstrating both processes of integration and fragmentation over time. While the middle and inner fjord areas appear somewhat defined as subregions in the late Roman and Migration periods, the fjord districts south of the Boknafjord appear more integrated with Jæren in the Viking Age, focused towards the Boknafjord basin.

These changing sub-regions and particularly the increased integration of the landscapes south of the Boknafjord in the Viking Age may reflect processes of centralisation. A correlation with clusters of boathouses in this area, and with the distribution of the slightly older courtyard sites, could relate to changes in juridical and maritime military structures. While there is no 'regional identity' or a regional distribution that reflects the population within a late Viking Age kingdom, as pointed out by Scull (2001) it is possible to approach formation processes by looking at spatial aspects of sub-regions with elite networks in combination with other 'infrastructures' such as courtyard sites or boathouses. Callmer (1991) argues that Scandinavia consisted of several social aggregates of varying form, extent, and character, and that some were smaller settlement districts, partly delimited by natural barriers, while others formed confederations and subsequently kingdoms with varying extents of overlordship. Within these larger constellations, the integration of the various settlements or landscapes may have varied, similarly as did the tendencies observed in this study. The trajectories of the subregions provide examples of both increasingly centralized landscapes as seen in the Viking Age south of Boknafjorden, characterised by shared practices and shared material culture, and the less integrated sub-regions characterised by a shifting degree of similarities/differences, such as between Jæren and the heathlands. 
Acknowledgements: Many thanks to Professor Dagfinn Skre and Professor Per Ditlef Fredriksen for discussions and feed-back on this paper. Thank as well to all participants in the IAKH PhD seminars for comments on earlier versions and excerpts of this text, and to the three anonymous reviewers for their comments and suggestions.

\section{References}

Almgren, Oscar 1897: Studien über nordeuropäische Fibelformen der ersten nachchristlichen Jahrhunderte: mit Berücksichtigung der provinzialrömischen und südrussischen Formen. Ivar Hæggström. Stockholm.

Andersen, Sveinung Bang 1968: Korsformede spenner fra Rogaland. Frá haug ok heiðni, 1968:1: 112-16.

Andersson, Kent 1993: Romartida guldsmide i Norden. Katalog. Aun, 17. Societas Archaeologica Upsaliensis. Uppsala.

Back Danielsson, I.-M. 2016: More Theory for Mortuary Research of the Viking World. European Journal of Archaeology 19:519-31.

Bakka, Egil 1993: Gauselfunnet og bakgrunnen for det. In: Bergljot Solberg and Egil Bakka (eds.): Minneskrift Egil Bakka. Arkeologiske skrifter, 7:248-304. Historisk museum, Universitetet i Bergen. Bergen.

Barth, Fredrik 1969: Introduction. In: Fredrik Barth (ed.): Ethnic groups and boundaries: the social organization of culture difference, pp. 9-38. Universitetsforlaget. Oslo.

Bauer, Egil Lindhart 2018: Two Iron Age Boathouses. In: Dagfinn Skre (ed.): Avaldsnes - A SeaKings' Manor in First-Millennium Western Scandinavia. Reallexikon der germanischen Altertumskunde - Ergänzungsbände, 104:183-208. Walter de Gruyter. Berlin, Boston.

Bauer, Egil Lindhart and Mari Arentz Østmo 2013: Kongsgårdprosjektet Avaldsnes. Stolpebygde hus, produksjonsplass, dyrkningsspor, steinkonstruksjon, kokegroper og naust fra jernalder og ruin fra middelalder. Avaldsnes prestegård, 86/1, Karmøy kommune, Rogaland. Unpublished report, University of Oslo, Museum of Cultural History. Oslo.

Bauer, Egil Lindhart and Mari Arentz Østmo 2018: Prehistoric Agriculture. In: Dagfinn Skre (ed.): Avaldsnes - A Sea-Kings' Manor in First-Millennium Western Scandinavia. Reallexikon der germanischen Altertumskunde - Ergänzungsbände, 104:137-56. Walter de Gruyter. Berlin, Boston.

Berg, Heidi Lund 2015: 'Truth' and reproduction of knowledge. Critical thoughts on the interpretation and understanding of Iron-Age keys. In: Marianne Hem Eriksen, Bernt Rundberget, Unn Pedersen, Irmelin Axelsen and Heidi Lund Berg (eds.): Viking worlds. Things, spaces and movement, pp. 124-42. Oxbow. Oxford.

Bergstøl, Jostein 1996: Synlige kvinner - usynlige menn. Graver og ideologi på Jæren i eldre jernalder. Viking, 59:63-77.

Bjørkvik, Halvard 1999: Avaldsnes i førhistorisk tid og tidleg historisk tid. In: Svein Ivar Langhelle, Birger Lindanger, Halvard Bjørkvik, Knut Helle and Hans-Emil Lidén (eds.): Kongskyrkje ved Nordvegen: Olavskyrkja på Avaldsnes 750 år, pp. 9-53. Lokalhistorisk stiftelse. Aksdal.

Boivin, Nicole 2008: Material cultures, material minds. The impact of things on human thought, society, and evolution. Cambridge University Press. Cambridge.

Bonde, Niels and Frans-Arne Stylegar 2009: Fra Avaldsnes til Oseberg. Dendrokronologiske undersøkelser av skipsgravene fra Storhaug og Grønhaug på Karmøy. Viking 72:149-68. 
Bourdieu, Pierre 1977: Outline of a theory of practice. Esquisse d'une théorie de la pratique, 16. Cambridge University Press. Cambridge.

Braathen, Helge 1989: Ryttergraver. Politiske strukturer i eldre rikssamlingstid. Varia, 19. Oslo.

Brink, Stefan, et al. 2011: Court Sites of Arctic Norway: Remains of Thing Sites and Representations of Political Consolidation Processes in the Northern Germanic World during the First Millennium AD? Norwegian Archaeological Review, 44 1:89-117.

Børsheim, Ragnar L., et al. 2002: Gausel: utgravingene 1997-2000. AmS-Varia, 39. Arkeologisk Museum i Stavanger. Stavanger.

Callmer, Johan 1991: Territory and Dominion in the Late Iron Age in Southern Scandinavia. In: Kristina Jennbert, Lars Larsson, Rolf Petré and Bozena Wyszomirska-Werbart (eds.): Regions and Reflections. In Honour of Märtha Strömberg. Acta Archaeologica Lundensia Ser. in 8ㅜ, 20: 257-73. Almqvist \& Wiksell. Lund.

Callmer, Johan, et al. 2017: Identity Formation and Diversity: Introduction. In: Johan Callmer, Ingrid Gustin and Mats Roslund (eds.): Identity formation and diversity in the early medieval Baltic and beyond. Communicators and communication. The northern world, North Europe and the Baltic, c. 400-1700 AD. Peoples, economics and cultures, 75:1-16. Brill. Leiden, Boston.

Carver, Martin 2011: What were they thinking? Intellectuall territories in Anglo-Saxon England. In: Helena Hamerow, Sally Crawford and David A. Hinton (eds.): The Oxford handbook of AngloSaxon archaeology. Oxford Handbooks in Archaeology, pp. 932-66. Oxford University Press. Oxford.

Curta, Florin 2007: Some remarks on ethnicity in medieval archaeology. Early Medieval Europe, 15 2:159-85.

Engevik, Asbjørn 2010: Technological style, regional diversity and identity. Asbestos regions and soapstone regions in Norway in the Late Roman and Migration Periods. In: Randi Barndon, Asbjørn Engevik and Ingvild Øye (eds.): The Archaeology of regional technologies. Case studies from the Palaeolithic to the age of the Vikings, pp. 228-41. Edwin Mellen Press, cop. 2010. Lewiston, NY.

Fabech, Charlotte and Jytte Ringtved 1991: Samfundsorganisation og regional variation. Norden $\mathrm{i}$ romersk jernalder og folkevandringstid. Beretning fra 1. nordiske jernaldersymposium på Sandbjerg Slot 11-15 april 1989. Jysk Arkæologisk Selskabs skrifter, 27. Aarhus Universitetsforlag. Århus.

Feinman, Gary M. 2017: Economic aspects of globalization in the past material world. In: Tamar Hodos (ed.): The Routledge Handbook of Archaeology and Globalization, pp. 66-77. Routledge.

Fontijn, David and Sasja van der Vaart-Verschaaf 2017: Local elites globalized in death. A practice approach to Early Iron Age Hallstatt CD/D chieftains' burials in northwest Europe. In: Tamar Hodos (ed.): The Routledge handbook of archaeology and globalization, pp. 522-36. Routledge.

Gammeltoft, Peder and Søren Michael Sindbæk 2008: Historisk regionalitet på tværs af faggrænser. In: Peder Gammeltoft, Søren Michael Sindbæk and Jens Vellev (eds.): Regionalitet i Danmark i Vikingetid og Middelalder, pp. 7-14. Hikuin.

Gammeltoft, Peter, et al. (eds.) 2008: Regionalitet i Danmark i vikingetid og middelalder. Tværfagligt symposium på Aarhus Universitet 26. januar 2007. Hikuin, 35. Hikuin. Højbjerg.

Gjerpe, Lars Erik 2016: Iron Age building traditions in Eastern Norway: regions and landscapes. In: Frode Iversen and Håkan Petersson (eds.): The Agrarian Life of the North $2000 B C-A D$ 1000. Studies in Rural Settlement and Farming in Norway, pp. 203-19. Portal, Oslo. Kristiansand.

Gjerpe, Lars Erik 2017: Effektive hus. Bosetning, jord og rettigheter på Østlandet i jernalder. Unpublished PhD-thesis. Universitetet i Oslo, Det humanistiske fakultet. 
Glørstad, Ann Zanette Tsigaridas 2010: Ringspennen og kappen. Kulturelle møter, politiske symboler og sentraliseringsprosesser i Norge ca. 800-950. Unpublished PhD-thesis, Universitetet i Oslo.

Glørstad, Zanette Tsigaridas 2012: Sign of the Times? The Transfer and Transformation of Penannular Brooches in Viking-Age Norway. Norwegian Archaeological Review, 45:1: 30-51.

Gosden, Chris 2005: What Do Objects Want? Journal of Archaeological Method and Theory, 12 3: 193-211.

Gosden, Chris and Yvonne Marshall 1999: The cultural biography of objects. World Archaeology, 31 2:169-78.

Graeber, David 2010: On the Moral Grounds of Economic Relations. A Maussian Approach. Working Papers Series. 6. Open Anthropology Cooperative Press. http://openanthcoop.net/press/ http://openanthcoop.net/press/wp-content/uploads/2010/11/Graeber-On-the-Moral-Groundsof-Economic-Relations4.pdf. accessed 20.04.2016.

Gräslund, Bo and Neil Price 2012: Twilight of the gods? The 'dust veil event' of AD 536 in critical perspective. Antiquity, 86 332:428-43.

Hansen, Ulla Lund 1970: Kvarmløsefundet - en analyse af Sösdalastilen og dens forudsætninger. Aarbøger for nordisk oldkyndighed og historie, 1969:63-102.

Hansen, Ulla Lund 1995: Himlingøje-Seeland-Europa. Ein Gräberfeld der jügeren römischen Kaiserzeit auf Seeland, seine Bedeutung und internationalen Beziehungen. Nordiske fortidsminder. Serie B, 13. Kongelige Nordiske Oldskriftselskab. Copenhagen.

Hansen, Ulla Lund and Marzena Przybyla 2010: Rosettenfibeln - ein Klassifikationsversuch. In: Ulla Lund Hansen and A. Bitner-Wroblewska (eds.): Worlds apart? Contacts across the Baltic Sea in the Iron Age. Network Denmark-Poland, 2005-2008. Nordiske Fortidsminder, Ser. C, 7: 241-86. Det Kongelige Nordiske Oldskriftselskab. København, Warszawa.

Hauken, Åsa Dahlin 2005: The Westland cauldrons in Norway. AMS-Skrifter, 19. Arkeologisk Museum i Stavanger. Stavanger.

Hauken, Åsa Dahlin 2014: Appendix 1: katalog over jernalderfunnene på Hauge gnr. 19 og Tu gnr. 17, Klepp kommune. In: Elna Siv Kristoffersen, Einar Solheim Pedersen and Marianne Nitter (eds.): Et Akropolis på Jæren. Tinghaugplatået gjennom jernalderen, pp. 141-56. Arkeologisk museum i Stavanger.

Hedeager, Lotte 1992a: Centerdannelse i et langtidsperspektiv. Danmarks jernalder. In: Jan Henning Larsen and Egil Mikkelsen (eds.): Økonomiske og politiske sentra i Norden ca 400-1000 e. Kr. Åkerseminaret, Hamar 1990. Universitetets oldsaksamlings skrifter. Ny rekke, 13:89-95.Universitetets oldsaksamling. Oslo.

Hedeager, Lotte 1992b: Danmarks jernalder. Mellem stamme og stat. Aarhus Universitetsforlag. Århus.

Helgesson, Bertil 2003: Central places and regions in Scania during the Iron Age: Some examples. Acta archaeologica Lundensia. Series in 8 40:323-35.

Helgesson, Bertil 2008: Kan regionalitet påvisas genom arkeologiskt fyndmaterial? Några metodiska och källkritiska närmanden. Hikuin 35:49-62.

Helliesen, Tor 1901: Oldtidslevninger i Stavanger Amt. Med et kart over Haalands Pgd. Stavanger museums årshefte, Dreyer. Stavanger.

Hodos, Tamar 2017: Globalization. Some basics. An introduction to 'The Routledge Handbook of Archaeology and Globalization'. In: Tamar Hodos (ed.): The Routledge handbook of archaeology and globalization, pp. 3-11. Routledge.

Holst, Mads Kähler 2014: Warrior aristocracy and village community: Two fundamental forms of social organisation in the Late Iron Age and Viking Age In: Ernst Stidsing, Karen Høilund 
Nielsen and Reno Fiedel (eds.): Wealth and Complexity: Economically specialised sites in Late Iron Age Denmark, pp. 179-97. Aarhus Universitetsforlag. Aarhus.

Hoskins, Janet 2006: Agency, Biography and Objects. In: Christopher Tilley, Webb Keane, Susanne Küchler, Michael Rowlands and Patricia Spyer (eds.): Handbook of Material Culture, pp. 74-84. SAGE Publications, London.

Hyenstrand, Åke 1974: Centralbygd - randbygd. Strukturella, ekonomiska och administrativa hovudlinjer i mellansvensk yngre järnalder. Almqvist \& Wiksell. Stockholm.

Iversen, Frode 2008: Eiendom, makt og statsdannelse. Kongsgårder og gods i Hordaland i yngre jernalder og middelalder. UBAS, 6. Institutt for arkeologi, historie, kultur og religionsvitenskap, Universitetet i Bergen. Bergen.

Iversen, Frode 2013: Big bang, lordship or inheritance? Changes in the settlement structure on the threshold of the Merovingian period, South-East Norway. In: Jan Klaptse (ed.): Hierarchies in rural settlements, pp. 341-58. Brepols. Turnhout.

Iversen, Frode 2018: Emerging Kingship in the 8th Century? New Datings of three Courtyard Sites in Rogaland In: Dagfinn Skre (ed.): Avaldsnes - A Sea-Kings' Manor in First-Millennium Western Scandinavia. Reallexikon der germanischen Altertumskunde - Ergänzungsbände, 104:721-46. Walter de Gruyter. Berlin, Boston.

Jensen, Atle 1998: Likearmede spenner. Overgangen mellom eldre og yngre jernalder i Norge - en kronologisk analyse. Unpublished master thesis. Universitetet i Bergen, Bergen.

Jones, A. 2004: Archaeometry and materiality: Materials-based analysis in theory and practice. Archaeometry, 46:327-38.

Joy, Jody 2009: Reinvigorating object biography: reproducing the drama of object lives. World Archaeology, 41:4:540-56.

Jørgensen, Lars 1991: Våbengrave og krigeraristokrati. Etableringen af en centralmagt på Bornholm i 6-8 århundre. In: Peder Mortensen and Birgit M. Rasmussen (eds.): Høvdingesamfund og kongemagt. Fra stamme til stat i Danmark, 2:109-24. Aarhus universitetsforlag. Århus.

Klevnäs, Alison Margaret 2016: 'Imbued with the Essence of the Owner'. Personhood and Possessions in the Reopening and Reworking of Viking-Age Burials. European Journal of Archaeology, 19 3:456-76.

Klæsøe, Iben Skibsted 1999: Vikingetidens kronologi - en nybearbejdning af det arkæologiske materiale. Aarbøger for Nordisk oldkyndighed og Historie 1997:89-142.

Knappett, Carl 2017: Globalization, connectivities and networks. In: Tamar Hodos (ed.): The Routledge Handbook of Archaeology and Globalization, pp. 29-40. Routledge. Oxon, New York.

Kristoffersen, Siv 1999: Migration Period chronology in Norway. In: John Hines, Karen Høilund Nielsen and Frank Siegmund (eds.): The Pace of change: studies in early-medieval chronology. Cardiff studies in archaeology, pp. 93-114. Oxbow Books. Oxford.

Kristoffersen, Siv 2000: Sverd og spenne. Dyreornamentikk og sosial kontekst. Studia humanitatis Bergensia, 13. Høyskoleforlaget. Kristiansand.

Kristoffersen, Siv 2004a: Husfruen. Formidling av fortidige roller. In: Lotte Selsing (ed.): Feministisk teori, kvinne- og kjønnsforskning i Rogaland. AmS-Varia, 41:59-66. Stavanger.

Kristoffersen, Siv 2004b: Symbolism in rites of transition in Iron Age Norway. In: S. De Bouvrie and M. Wedde (eds.): Celebration, Sanctuaries and Vestiges of Cult practice. Papers from the Norwegian Institute at Athens, 6, The Norwegian Institute at Athens. Jonsherred.

Kristoffersen, Siv 2006: Kvinnedrakten fra Rogaland i folkevandringstid. AmS-Varia, 45. Arkeologisk museum i Stavanger. 
Kristoffersen, Siv 2012: Brooches, bracteates and a goldsmith's grave. In: A. Pesch and R. Blankenfeldt (eds.): Goldsmith mysteries. Archaeological, pictorial and documentary evidence from the 1st millennium AD in northern Europe. Schriften des Archäologischen Landesmuseum, pp. 169-76. Wachholtz Verlag. Neumünster.

Kristoffersen, Siv and Bente Magnus 2010: Spannformete kar. Utvikling og variasjon. AmS-Varia, Arkeologisk museum, Universitetet i Stavanger.

Kristoffersen, Siv, et al. (eds.) 2014: Et Akropolis på Jæren? Tinghaugplatået gjennom jernalderen. AmS-Varia, 55. Arkeologisk museum, Universitetet i Stavanger. Stavanger.

Kristoffersen, Siv and Terje Østigård 2008: "Death Myths" - Performing of Rituals and Variation in Corpse Treatment during the Migration Period in Norway. The Materiality of death: Bodies, burials, beliefs. BAR international series, 1768:127-39. Archaeopress. Oxford.

Lillehammer, Grete 1996: Død og grav. Gravskikk på Kvassheimfeltet, Hå i Rogaland, SV Norge. AmS Skrifter, 13. Arkeologisk museum i Stavanger. Stavanger.

Lillehammer, Grete 2014: Jærens Akropolis. Landskap og fornminner på Anda-/Tuhøyden. In: Siv Kristoffersen, Marianne Nitter and Einar Solheim Pedersen (eds.): Et Akropolis på Jæren? Tinghaugplatået gjennom jernalderen. AmS-Varia, 55, Arkeologisk museum, Universitetet i Stavanger.

Lund-Hansen, Ulla 2001: Gold Rings - Symbols of Sex and Rank. In: Bente Magnus (ed.): Roman gold and the development of the early Germanic kingdoms. Aspects of technical, sociopolitical, socio-economic, artistic and intellectual development, A.D. 1-550. Kungl. vitterhets historie och antikvitets akademien, Konferenser, 51:157-88. Stockholm.

Magnus, Bente 1975: Krosshaugfunnet: et fors $ø k$ på kronologisk og stilhistorisk plassering i 5. årh. Stavanger museums skrifter, 9. Stavanger museum. Stavanger.

Magnus, Bente 2002: En liten gylden ring. In: John Pind and et al. (eds.): Drik - og du vil leve skønt. Festskrift til Ulla Lund Hansen på 60-årsdagen 18. august 2002. Publications from the National Museum, Studies in archaeology \& history, 7:255-62. National Museum. Copenhagen.

Magnus, Bente 2014: Kvinnene fra Krosshaug i Klepp og Hol på Inderøya. In: Elna Siv Kristoffersen and et al. (eds.): Et Akropolis på Jæren? Tinghaugplatået gjennom jernalderen. AmS-Varia, 55:71-87. Arkeologisk museum, Universitetet i Stavanger. Stavanger.

Mauss, Marcel 2002: The gift. The form and reason for exchange in archaic societies. Routledge classics, Routledge. London.

Meling, Trond 2014: To graver med hest og hesteutstyr fra Tu. Maktpolitiske forhold på Sørvestlandet i yngre jernalder. Et Akropolis på Jæren? Tinghaugplatået gjennom jernalderen. AmS-Varia, 55: 107-15. Stavanger. Arkeologisk museum i Stavanger.

Meyer, Eva Nissen 1934: Relieffspenner i Norden. Bergens museums aarbok, 4. Bergens museum. Bergen.

Myhre, Bjørn 1985: Boathouses as indicators of political organization. Norwegian Archaeological Review, 18:1-2:36-60.

Myhre, Bjørn 1987: Chieftain's graves and chiefdom territories in South Norway in the Migration Period. Studien zur Sachsenforschung, 6:169-88.

Myhre, Bjørn 1991: Bosetning og politisk organisasjon i Vest-Norge før vikingtid. In: Jóan Pauli Joensen, Ruth Johansen, Jan Kløvstad and Bjørn Myhre (eds.): Nordatlantiske foredrag. Seminar om nordatlantisk kulturforskning i Nordens hus på Færøerne 27.-30. august 1990. Annales Societatis Scientiarum Færoensis. Supplementa, 15:10-19. Norðurlandahúsid í Føroyum. Torshavn.

Myhre, Bjørn 2002: Landbruk, landskap og samfunn 4000 f.Kr.-800 e.Kr. In: Bjørn Myhre og Ingvild Øye (ed.): Norges landbrukshistorie 4000 f.Kr.-1350 e.Kr. Jorda blir levevei, 1:11-213. Det Norske Samlaget. Oslo. 
Myhre, Bjørn 2007: Lye i Time på Jæren i Sørvest-Norge - et glemt sentralsted fra eldre jernalder. http://www.jenny-rita.org/bjomyh.html. accessed 01.05.2018.

Myhre, Bjørn 2013: Katastrofetid eller samfunnsendring? (550-800 e. Kr.). In: Marie SmithSolbakken and Jan Bjarne Bøe (eds.): Frå eldste tider til 1000-talet. Hå kulturhistorie, 1: 291-8. Akademika forl. Trondheim.

Myhre, Lise Nordenborg 1998: Historier fra en annen virkelighet. Fortellinger om bronsealderen ved Karmsundet. AmS-småtrykk, 46. Arkeologisk museum i Stavanger. Stavanger.

Nicolay, Johan AW 2014: The Splendour of Power. Early Medieval Kingship and the Use of Gold and Silver in the Southern North Sea Area (5th to 7th Century AD). Groeningen Archaeological Studies, 28. Groeningen Institute of Archaeology. Barkhuis.

Näsman, Ulf 1991: Nogle bemærkninger om det nordiske symposium "Samfundsorganisation og regional variation" på Sandbjerg Slot 11-15 april 1989. Samfundsorganisation og regional variation. Norden i romersk jernalder og folkevandringstid. beretning fra 1. nordiske jernaldersymposium på Sandbjerg Slot 11-15 april 1989. Jysk Arkæologisk Selskabs skrifter, 27:321-33. Aarhus Universitetsforlag. Århus.

Opedal, Arnfrid 1998: De glemte skipsgravene. Makt og myter på Avaldsnes. AmS-småtrykk, 47. Arkeologisk museum i Stavanger. Stavanger.

Opedal, Arnfrid 2010: Kongemakt og kongerike. Gravritualer og Avaldsnes-områdets politiske rolle 600-1000. Oslo arkeologiske serie, 13. Institutt for arkeologi, konservering og historie, Universitetet i Oslo. Oslo.

Opedal, Arnfrid 2016: Hafrsfjord og kampen om vikingtidens flåtebaser. Viking VXXIX:117-40.

Østigård, Terje 2015: Changing rituals and reinventing tradition. The burnt Viking ship at Myklebostad, Western Norway. In: Rasmus Brandt, Håkon Roland and Marina Prusac (eds.): Changing rituals and ritual changes. Function and Meaning in Ancient Funerary Practices pp. 359-77. Oxbow Books, 2015. Oxford.

Østigård, Terje and Joakim Goldhahn 2006: From the Dead to the Living: Death as transactions and Re-negotiations. Norwegian archaeological review, 39:1:27-48.

$\emptyset$ stmo, Mari Arentz 2018: Production Area. In: Dagfinn Skre (ed.): Avaldsnes - A Sea Kings' Manor in First-Millennium Western Scandinavia. Reallexikon der germanischen Altertumskunde Ergänzungsbände, 104:157-82. Walter de Gruyter. Berlin, Boston.

Østmo, Mari Arentz and Egil Lindhart Bauer 2018a: Grave Monuments at Avaldsnes. In: Dagfinn Skre (ed.): Avaldsnes - A Sea Kings' Manor in First-Millennium Western Scandinavia. Reallexikon der germanischen Altertumskunde - Ergänzungsbände, 104:227-51. Walter de Gruyter. Berlin, Boston.

Østmo, Mari Arentz and Egil Lindhart Bauer 2018b: Site Periods and Key Contexts. In: Dagfinn Skre (ed.): Avaldsnes - A Sea Kings' Manor in First-Millennium Western Scandinavia. Reallexikon der germanischen Altertumskunde - Ergänzungsbände, 104:83-102. Walter de Gruyter. Berlin, Boston.

Pedersen, Unn 2017: Vikingtidskvinner i maktens innerste sirkel. In: Karoline Kjesrud and Nanna Løkka (eds.): Dronningen i vikingtid og middelalder, pp. 99-125. Scandinavian Academic Press. Oslo.

Petersen, Jan 1928: Vikingetidens smykker. Stavanger museums skrifter, 2. Dreyers grafiske anstalt. Stavanger.

Petersson, Bodil, et al. 2008: Arkeologi och identitet: VIII Nordic TAG i Lund 2005. Acta archaeologica Lundensia. Series in $8^{\circ}, 53$. Institutionen för arkeologi och antikens historia, Lunds universitet. Lund.

Prøsch-Danielsen, Lisbeth and Asbjørn Simonsen 2000: The deforestation patterns and the establishment of the coastal heathland of southwestern Norway. Ams-Skrifter, 15. Arkeologisk Museum i Stavanger. 
Puschmann, Oskar 2005: Nasjonalt referansesystem for landskap. Beskrivelse av Norges 45 landskapsregioner. NIJOS-rapport, 10/2005. NIJOS, Norsk institutt for jord- og skogkartlegging. Ås.

Reichstein, J 1975: Die kreuzförmige Fibel. Zur Chronologie der späten römischen Kaiserzeit und der Völkerwanderungszeit in Skandinavien, auf dem Kontinent und in England. Offa-Bücher, 34. K. Wachholtz Verlag. Neumünster.

Reiersen, Håkon 2009: The central place of the Avaldsnes area, SW Norway. An analysis of elites and central functions along Karmsund 200 BC-AD 1000. University of Bergen. Unpublished master thesis.

Reiersen, Håkon 2010: Avaldsnes og Karmsundet i yngre romertid. Fragmenter fra et elitemiljø. In: Marianne Hem Eriksen and Ingar Gundersen (eds.): På sporet av romersk jernalder. Nicolay Skrifter, 3:64-78. Oslo.

Reiersen, Håkon 2011: Status Rings as Indicators of Centres in Western Norway in the Late Roman Iron Age. In: Linda Boye (ed.): Det 61. Internationale Sachsensymposion 2010. Haderslev, Danmark. Archäologie in Schleswig. Arkæologi i Slesvig, pp. 157-70. Wachholtz. Neumünster.

Reiersen, Håkon 2017: Elite milieus and centres in western Norway 200-550 AD. Universitetet i Bergen. Bergen.

Ringstad, Bjørn 1992: Økonomiske og politiske sentra på Vestlandet ca. 400-1000 e. Kr. In: Jan Henning Larsen and Egil Mikkelsen (eds.): Økonomiske og politiske sentra i Norden ca 400-1000 e. Kr. Åkerseminaret, Hamar 1990. Universitetets oldsaksamlings skrifter. Ny rekke, 13: 107-28.Universitetets oldsaksamling. Oslo.

Ringtved, Jytte 1988: Regionalitet. Et jysk eksempel fra yngre romertid og ældre germanertid. Fra stamme til stat i Danmark, 1:37-52. Jysk Arkæologiske Selskabs Skrifter

Rygh, Oluf 1885: Norske Oldsager. Cammermeyer. Christiania.

Røstad, Ingunn 2008: Fugl eller fisk? En liten fugleformet spenne fra merovingertid. Viking, 71:103-14.

Røstad, Ingunn M. and Zanette Glørstad 2015: Mot en ny tid? Merovingertidens ryggknappspenner som uttrykk for endring og erindring. In: Marianne Vedeler, Ingunn Marit Røstad and Ellen Cathrine Holte (eds.): Smykker. Personlig pynt i kulturhistorisk lys, pp. 181-210. Museumsforlaget. Trondheim.

Røstad, Ingunn Marit 2015: Draktspenner i folkevandringstid: smykker, folk og småkongedømmer. In: Lotte Hedeager (ed.): Dalemfunnet Norske oldfunn, 30: 55-67. Kulturhistorisk museum, Universitetet i Oslo. Oslo.

Røstad, Ingunn Marit 2016a: Smykkenes språk. Smykker og identitetsforhandlinger i Skandinavia ca. 400-650/700 e.Kr. Bind I. Institutt for arkeologi, konservering og historie. Det humanistiske fakultet, Universitetet i Oslo. Unpublished PhD-thesis.

Røstad, Ingunn Marit 2016b: Smykkenes språk. Smykker og identitetsforhandlinger i Skandinavia ca. 400-650/700 e.Kr. Bind II Appendix. Institutt for arkeologi, konservering og historie. Det humanistiske fakultet, Universitetet i Oslo. Unpublished PhD-thesis.

Scull, Christopher 2001: Local and regional identities and processes of state formation in fifth- to seventh-century England. Some archaeological problems. In: Birgit Arrhenius (ed.) Kingdoms and Regionality. Transactions from the 49th Sachensymposium 1998 in Uppsala, pp. 121-5, Stockholm University.

Shetelig, Haakon 1906: The cruciform brooches of Norway Bergens museums aarbok, 8. Bergen. Shetelig, Haakon 1910: Smaa broncespænder fra folkevandringstiden. Oldtiden, 1:51-99.

Shetelig, Haakon 1912: Vestlandske graver fra jernalderen. Bergens museums skrifter. Ny række, 2. J. Griegs boktrykkeri. Bergen.

Sindbæk, Søren M. 2008a: Kulturelle forskelle, sociale netværk og regionalitet i vikingetidens arkæologi. Hikuin, 35:63-84. 
Sindbæk, Søren M. 2008b: The Lands Of Denemearce. Cultural Differences and Social Networks Of The Viking Age In South Scandinavia. Viking and Medieval Scandinavia, 4:169-208.

Sindbæk, Søren M. 2010: Re-assembling regions. The social occasions of technological exchange in Viking Age Scandinavia. In: Randi Barndon, Ingvild Øye and Asbjørn Engevik (eds.): The Archaeology of Regional Technologies: Case Studies from the Palaeolithic to the Age of the Vikings, pp. 263-87, Edwin Mellen Press.

Sindbæk, Søren M. 2017: Urbanism and exchange in the North Atlantic/Baltic, 600-1000CE. In: Tamar Hodos (ed.): Routledge Handbook of Archaeology and Globalization, pp. 553-65. Routledge. Oxon, New York.

Skre, Dagfinn 1998: Herredømmet. Bosetning og besittelse på Romerike 200-1350 e. Kr. Acta humaniora, 32. Det historisk-filosofiske fakultet, Universitetsforlaget. Universitetet i Oslo.

Skre, Dagfinn 2018: Sea Kings by the Norðvegr. In: Dagfinn Skre (ed.): Avaldsnes - A Sea Kings' Manor in First-Millennium Western Scandinavia. Reallexikon der germanischen Altertumskunde - Ergänzungsbände, 104: 781-800. Walter de Gruyter. Berlin, Boston.

Slomann, Wencke 1977: Der Übergang zwischen der späten Kaiserzeit und der frühen Völkerwanderungszeit in Norwegen. Beiträge zur Chronologie der Völkerwanderungszeit. Antiquitas, Reihe 3:20:61-4.

Solberg, Bergljot 2000: Jernalderen i Norge: ca. 500 f.Kr.-1030 e.Kr. Cappelen Akademisk. Oslo.

Steuer, Heiko 1989: Archaeology and history. Proposals on the social structure of the Merovingian kingdom. In: Klavs Randsborg (ed.): The birth of Europe. Archaeology and social development in the first millennium A.D., pp. 100-22, L'Erma di Bretschneider. Roma.

Storli, Inger 2010: Court Sites of Arctic Norway. Remains of Thing Sites and Representations of Political Consolidation Processes in the Northern Germanic World during the First Millennium AD? Norwegian Archaeological Review, 43:2:128-44.

Stylegar, Frans-Arne 2001: Hovedgårder, stormenn og landnåm. In: Helge-Rolf Naley and Marit Synnøve Vea (eds.): Fiender og forbundsfeller. Regional kontakt gjennom historien. Karmøyseminaret 1999, pp. 37-64. Vikingfestivalen, Karmøy kommune. Kopervik.

Stylegar, Frans-Arne 2008: “... an ornament in peace and a defence in war”. Late Roman weapon graves and military organisation i Eastern Norway. In: Christopher Prescott, Julie Lund, Konstantinos Chilidis and Lotte Hedeager (eds.): Facets of archeology. Essays in honour of Lotte Hedeager on her 60th birthday, Oslo arkeologiske serie, 10, Institutt for arkeologi, konservering og historiske studier, Universitetet i Oslo. Oslo.

Sundqvist, Olof 2014: Gårdarna Hauge och Tu i Klepp. En kultplats med kvinnliga kultledare? In: Siv Kristoffersen, Marianne Nitter and Einar Solheim Pedersen (eds.): Et Akropolis på Jæren? Tinghaugplatået gjennom jernalderen. AmS-varia, 55:89-105. Arkeologisk museum, Universitetet i Stavanger. Stavanger.

Svanberg, Fredrik 2003: Death rituals in south-east Scandinavia AD 800-1000. Decolonizing the Viking age 2. Acta archaeologica Lundensia $4^{\circ}, 24$. Almqvist \& Wiksell International. Stockholm.

Tesch, Sten 1992: House, farm, and village in the Köpinge area from the Early Neolithic to the Early Middle Ages. In: Lars Larsson, Johan Callmer and Bertha Stjernquist (eds.): The archaeology of the cultural landscape. Fieldwork and research in a south Swedish rural region. Acta Archaeologica Lundensia, Ser. In 4 $, 19: 283-344$. Lund.

Witcher, Robert 2017: The globalized Roman world. In: Tamar Hodos (ed.): The Routledge handbook of archaeology and globalization, pp. 634-51. Routledge.

Zachrisson, Torun 2018: Depositional Traditions in Iron Age Kormt. In: Dagfinn Skre (ed.): Avaldsnes - A Sea-Kings' Manor in First-Millennium Western Scandinavia. Reallexikon der germanischen Altertumskunde - Ergänzungsbände, 104:687-720. Walter de Gruyter. Berlin, Boston. 


\section{Appendix: Overview of brooches found in burial context}

The selection criteria for the brooches included in this study is that the brooch is from a burial context and that some information of the monument or burial practices is available. The nature of this information ranges from brief mentions of an origin in a mound or cairn to detailed descriptions of inner constructions and secondary phases. In cases where information is not recorded/mentioned, they are left as blank and count as 'missing' in statistical distributions. 


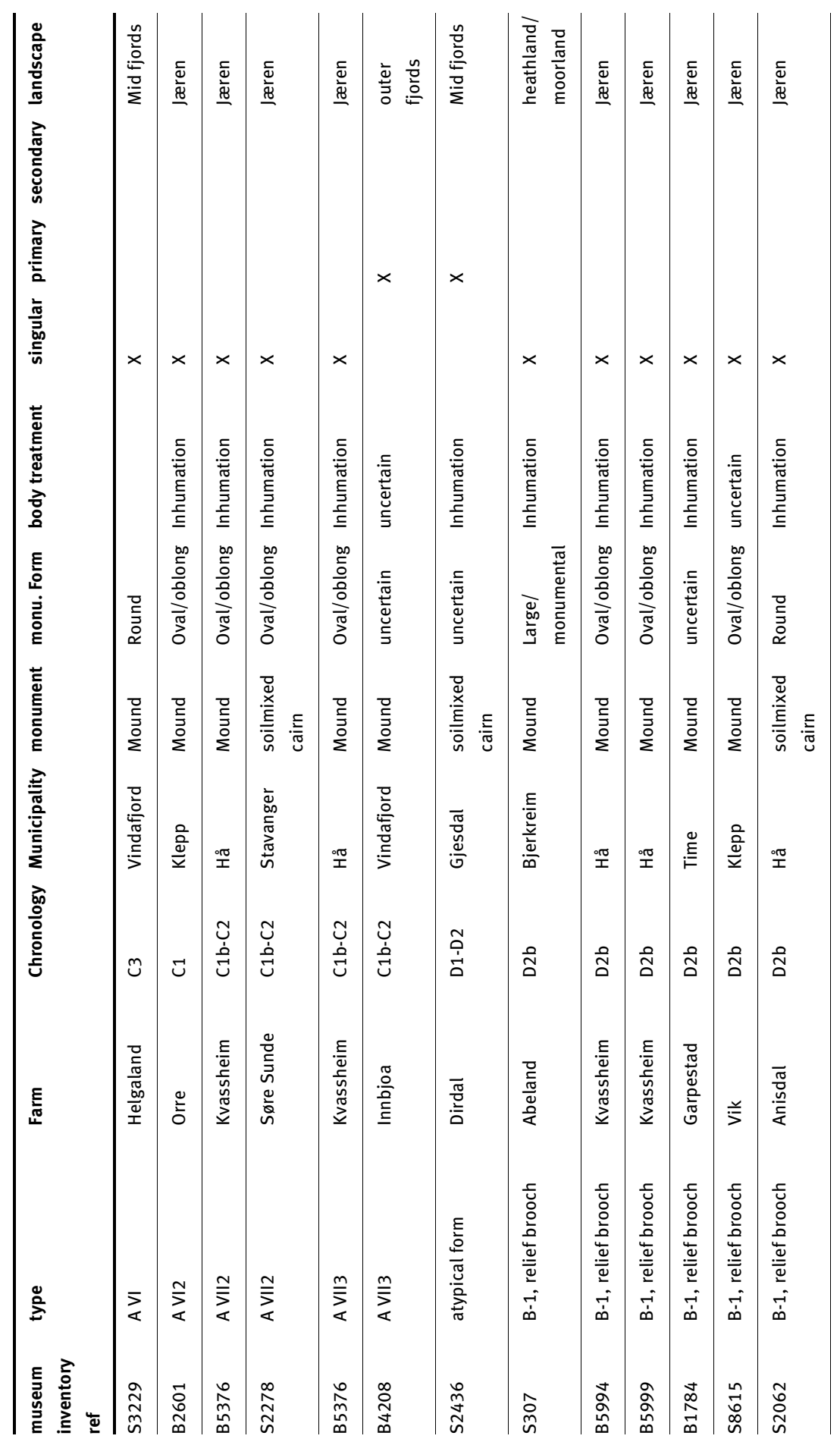




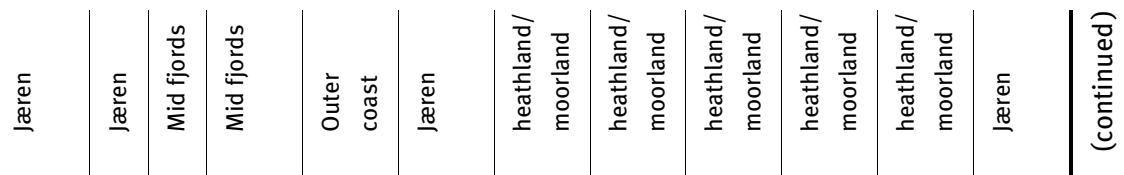

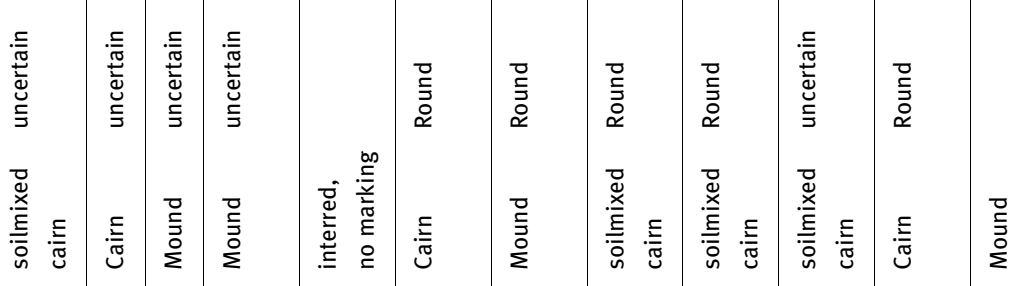

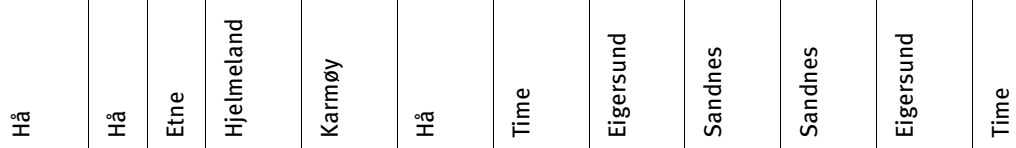

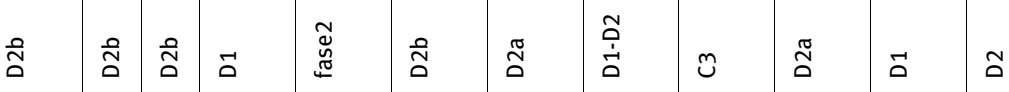

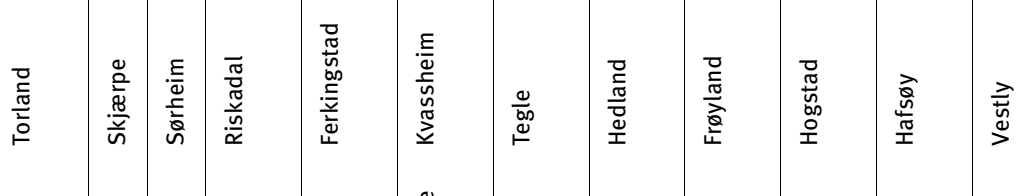

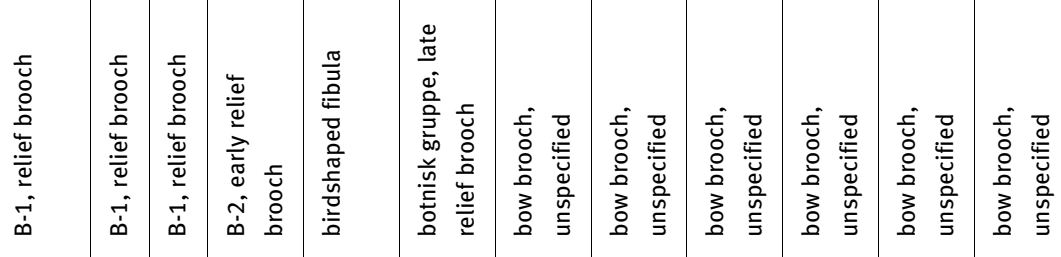

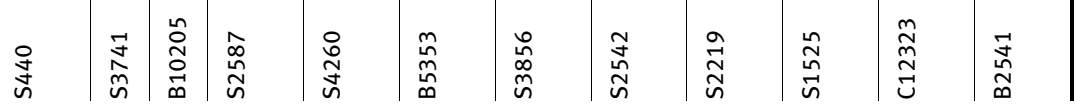




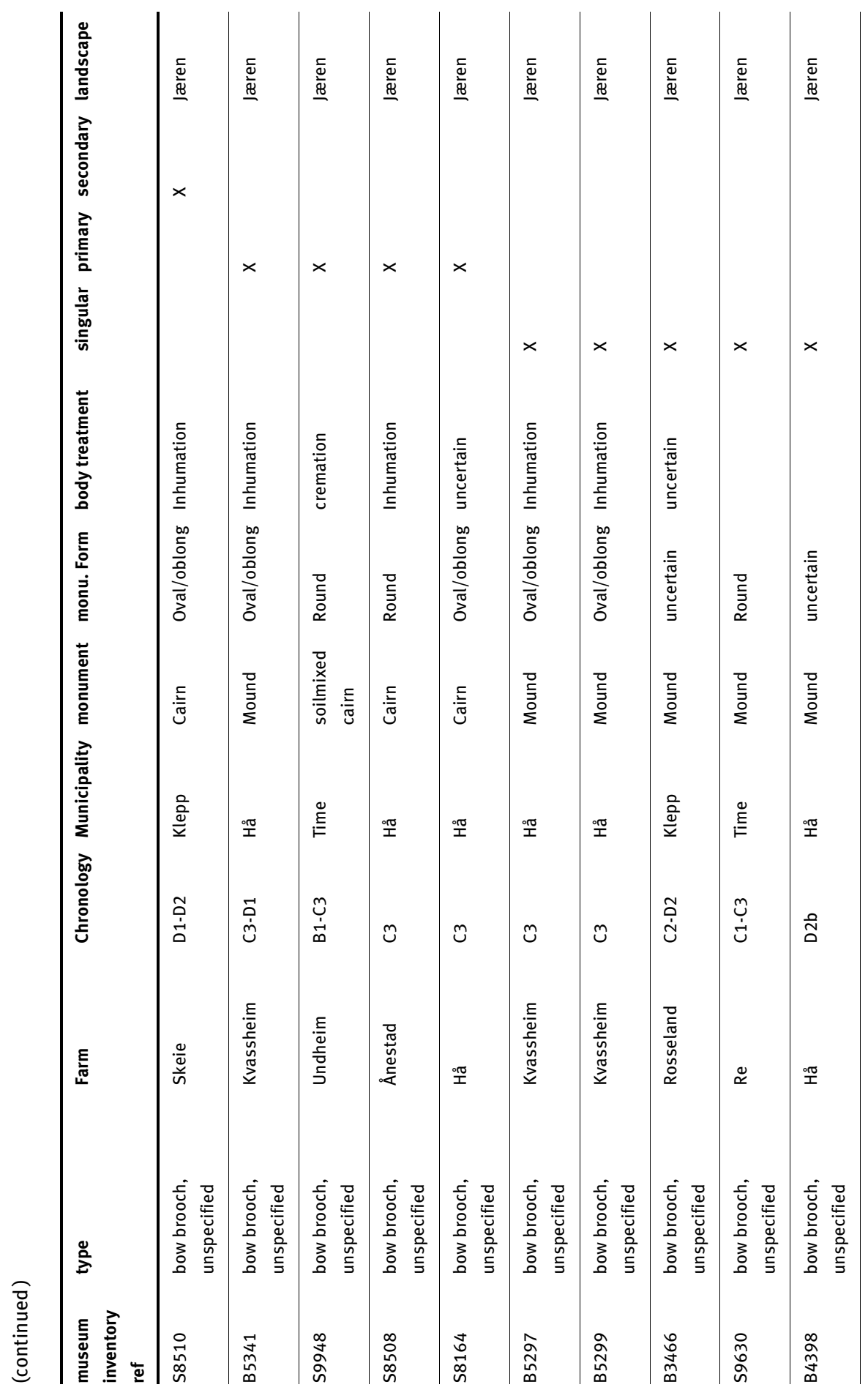




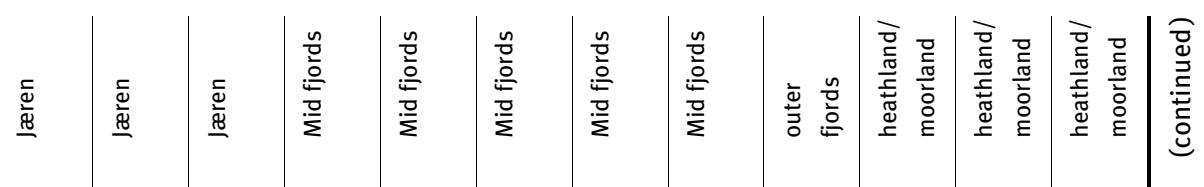

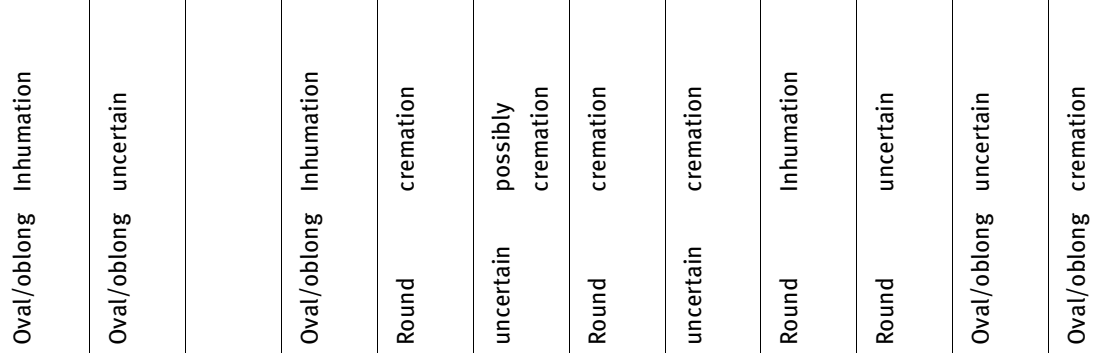

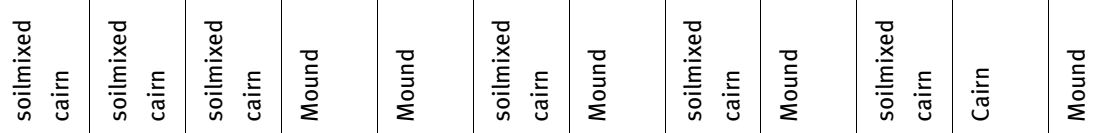

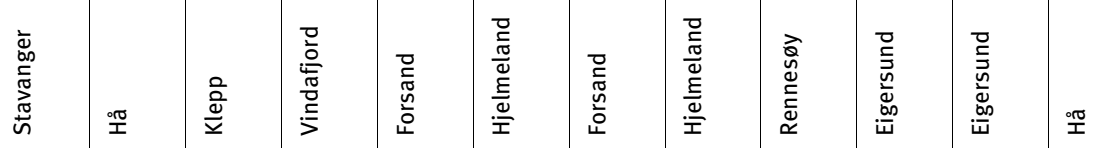

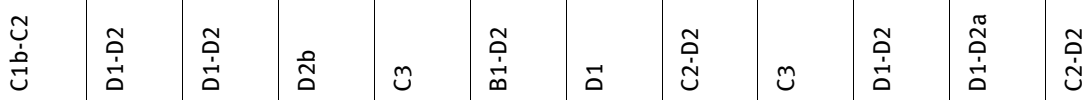

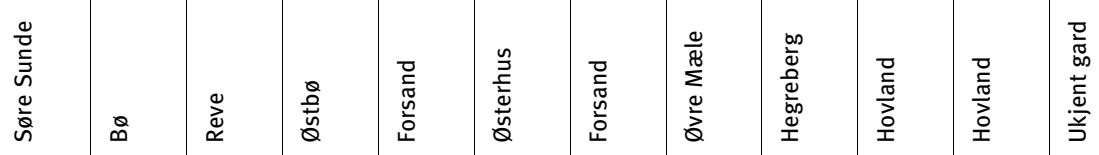

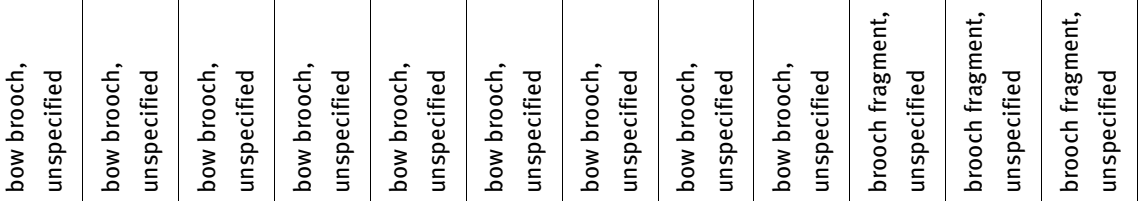

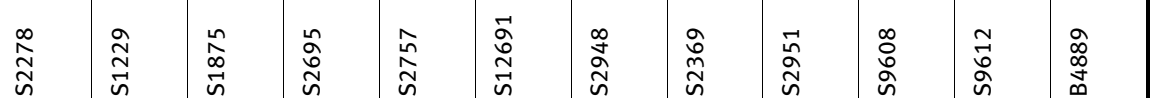




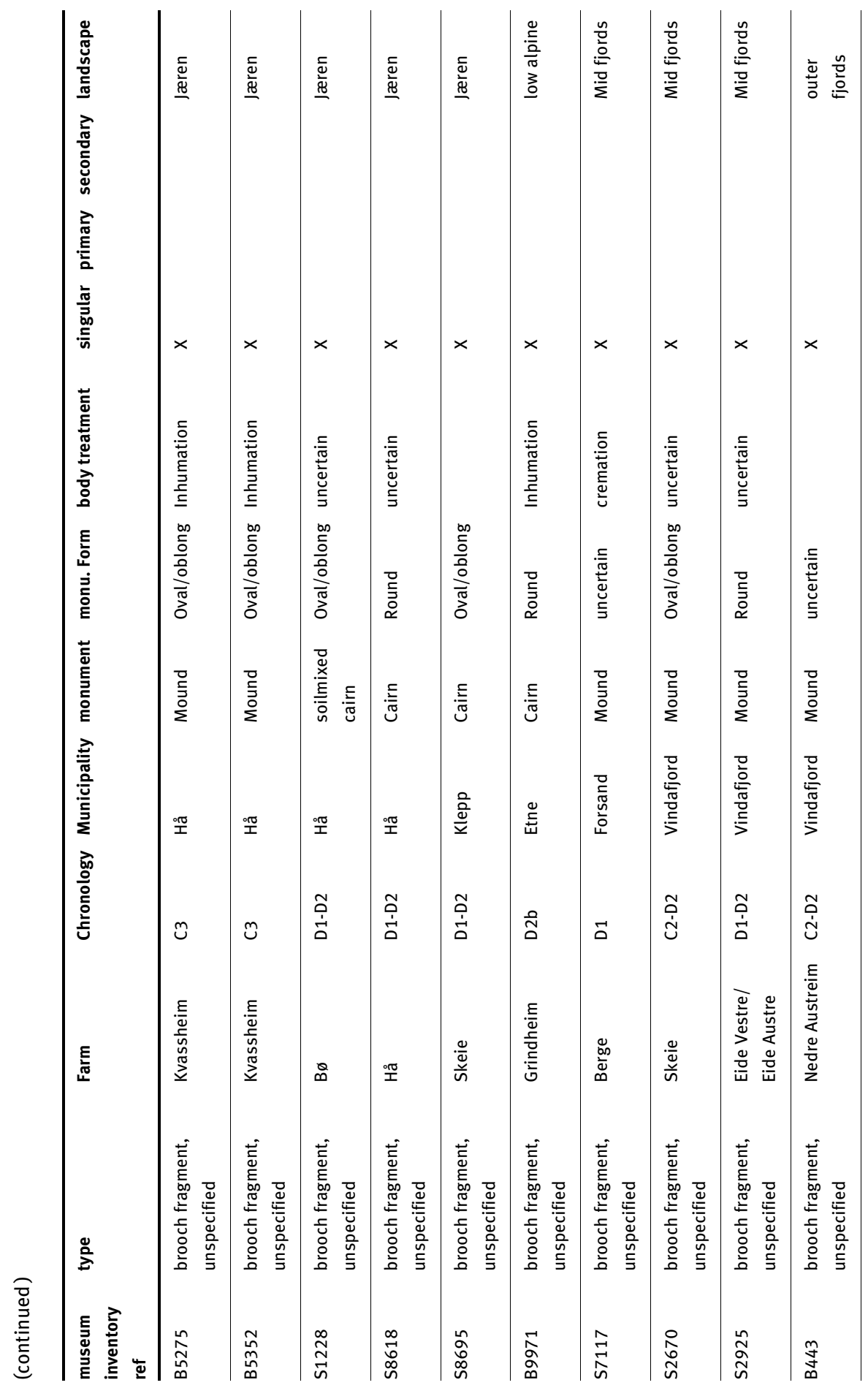




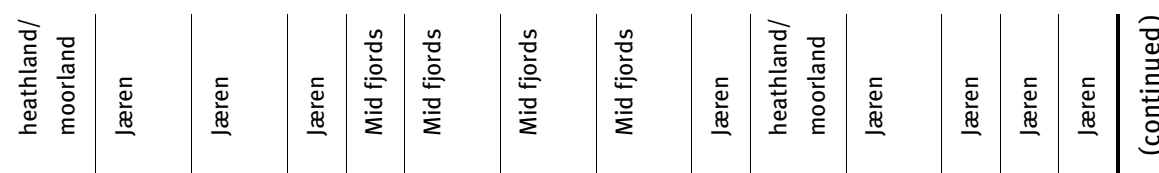

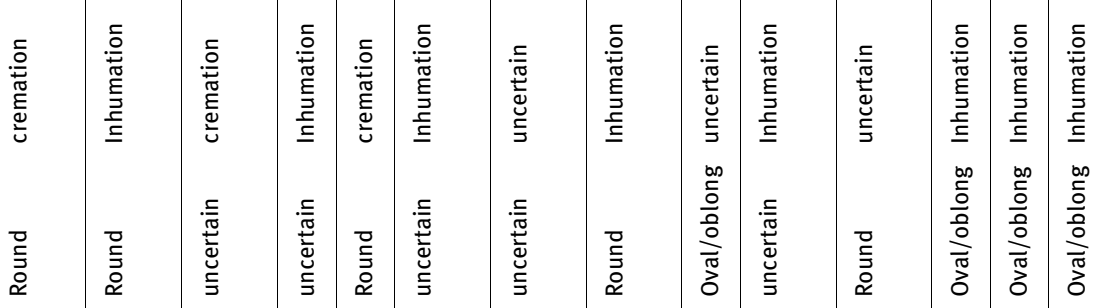

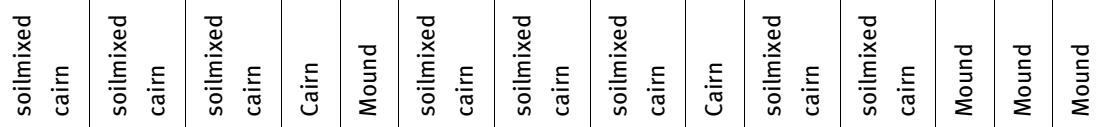

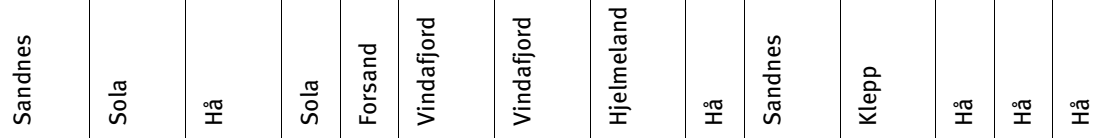

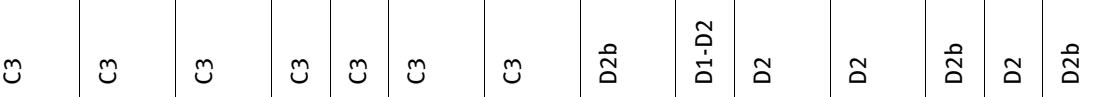

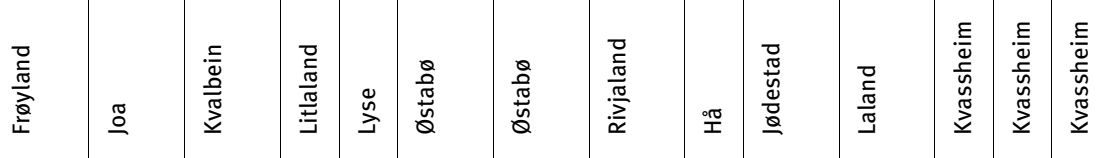

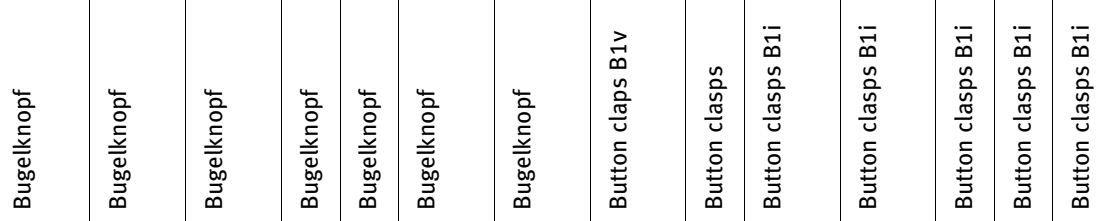

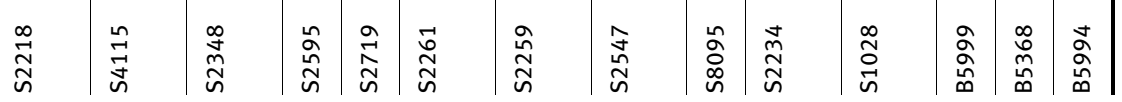




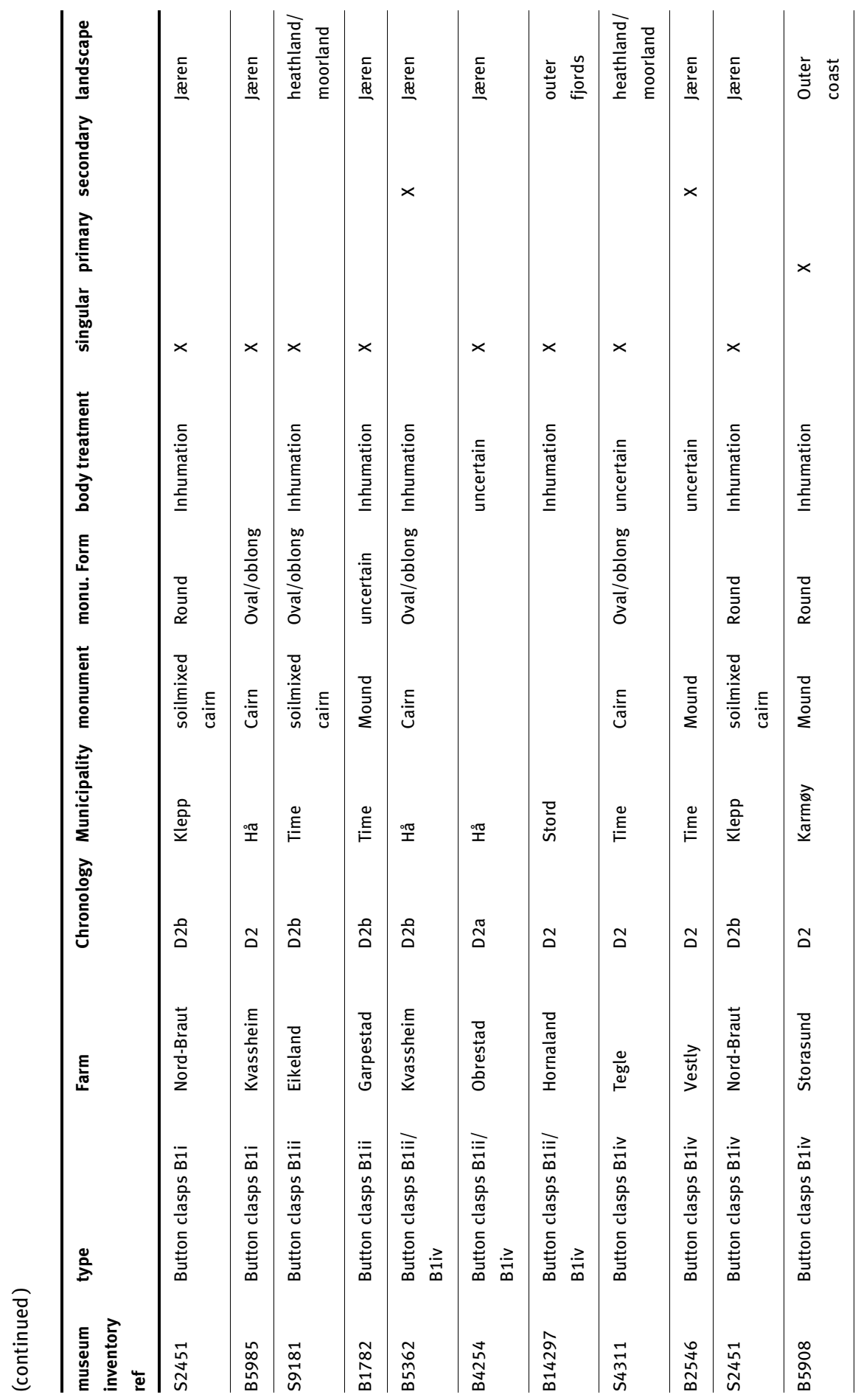




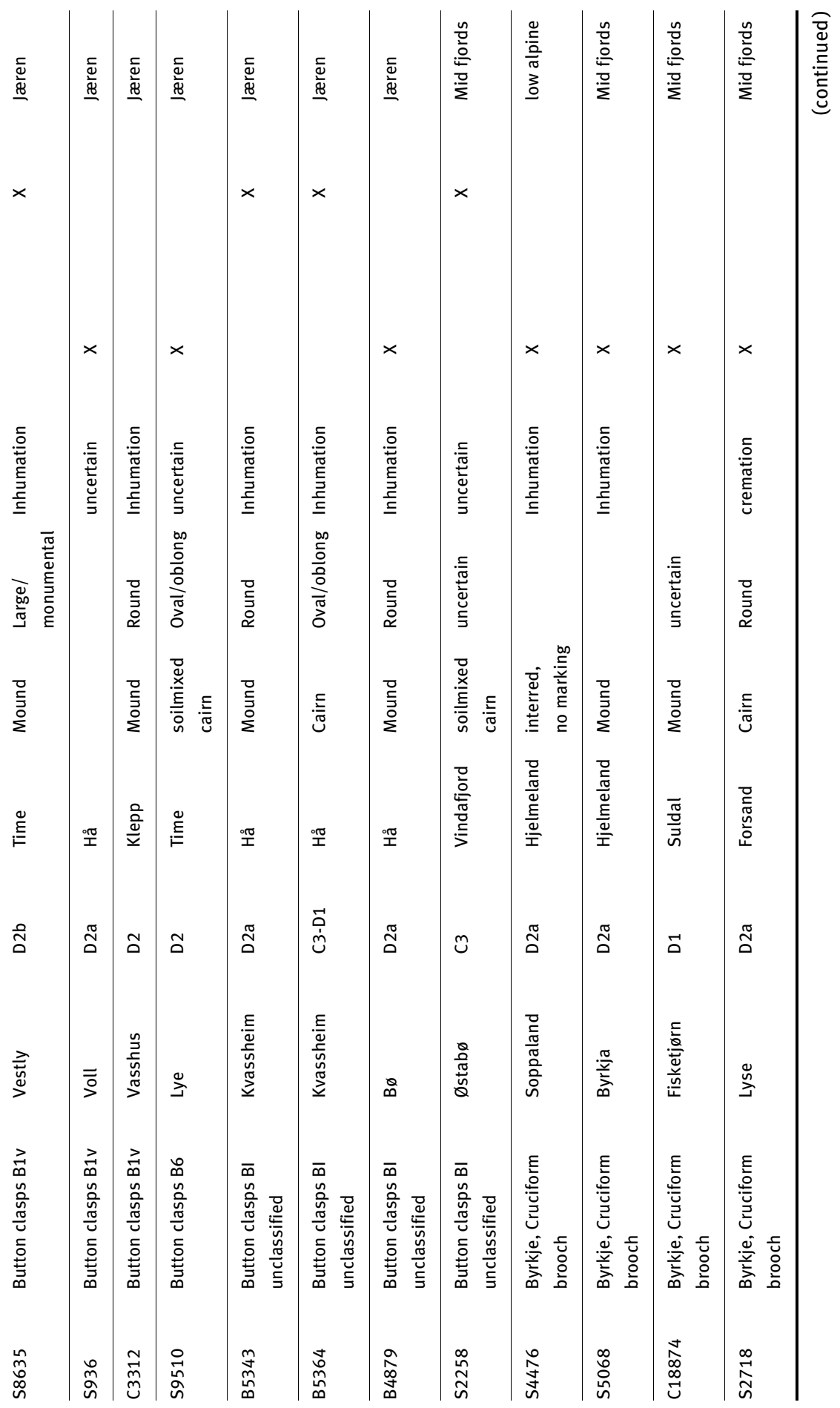




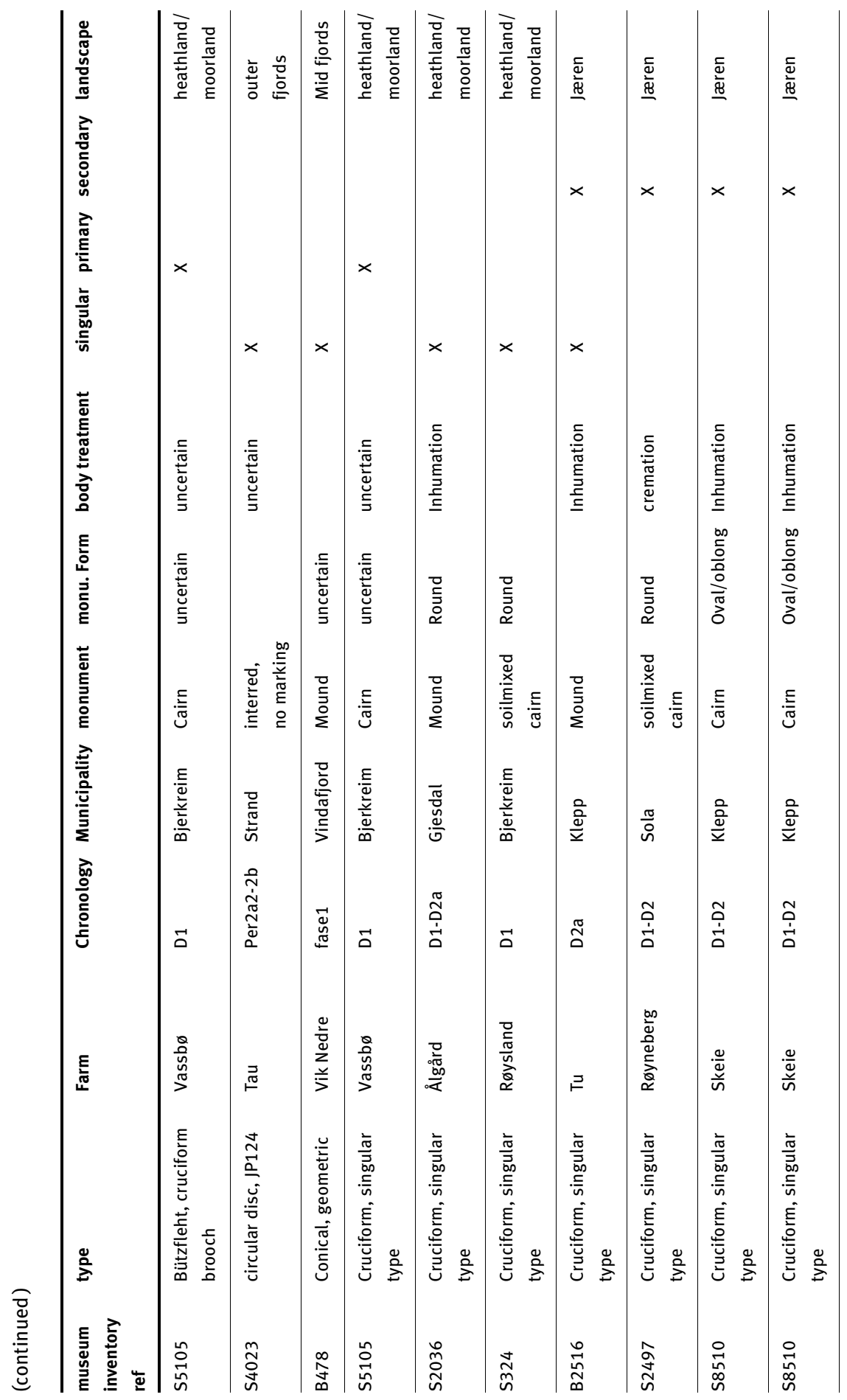




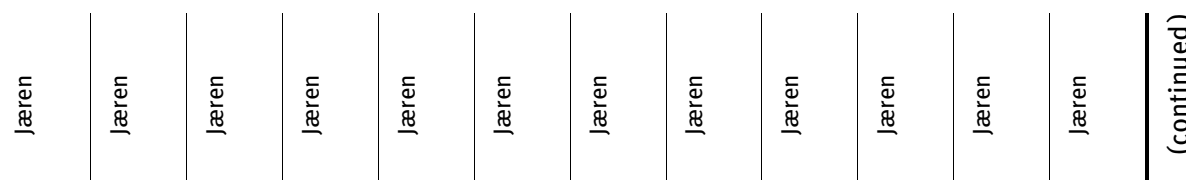

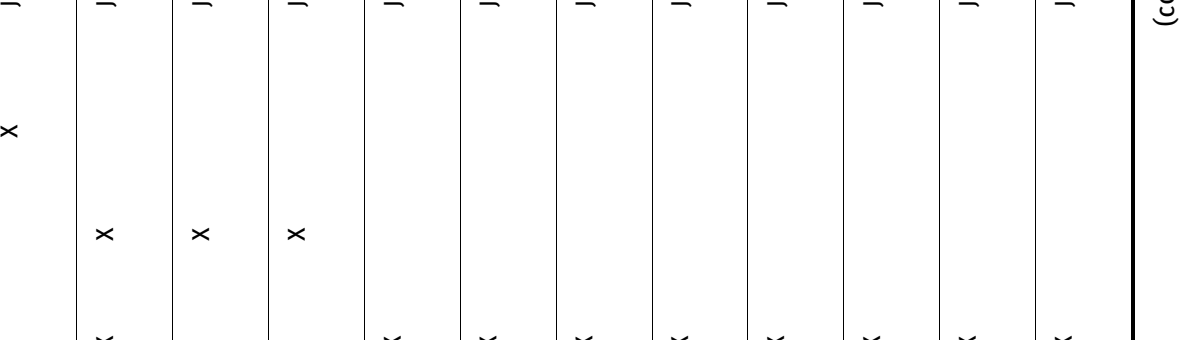

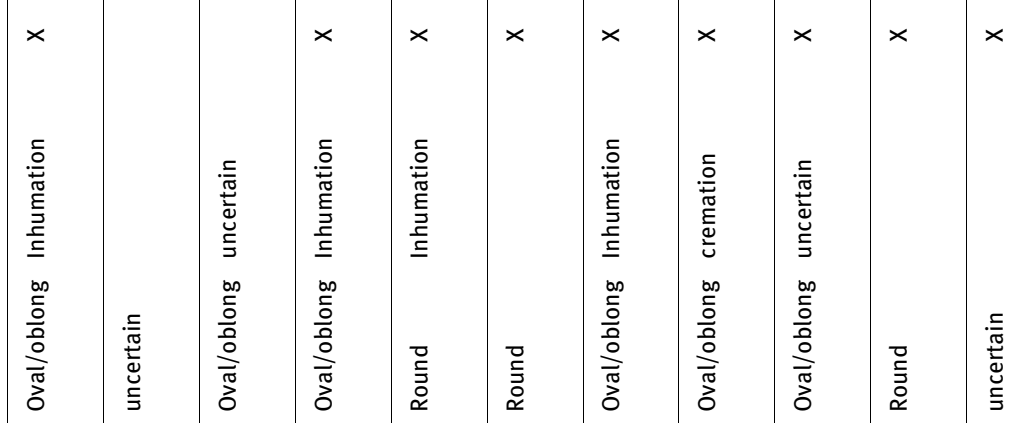

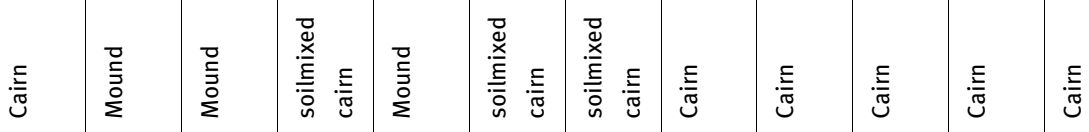

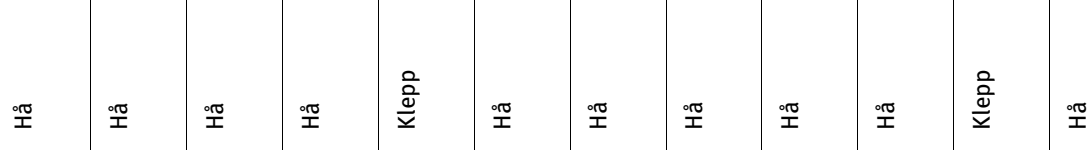

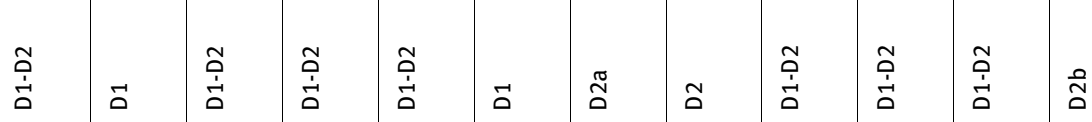

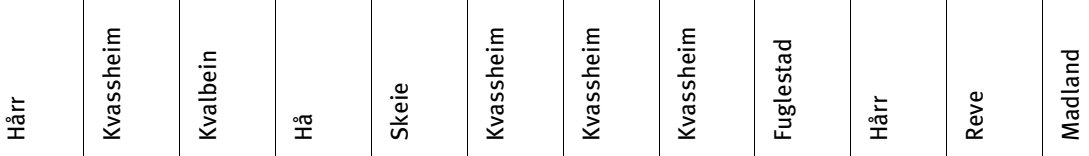

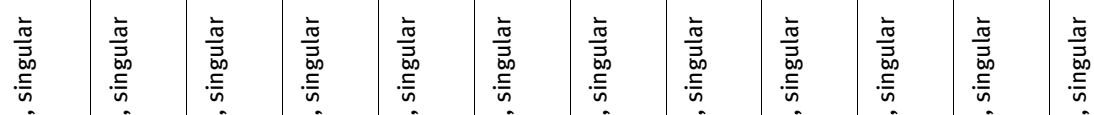

童

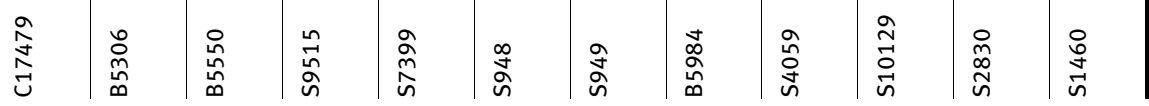




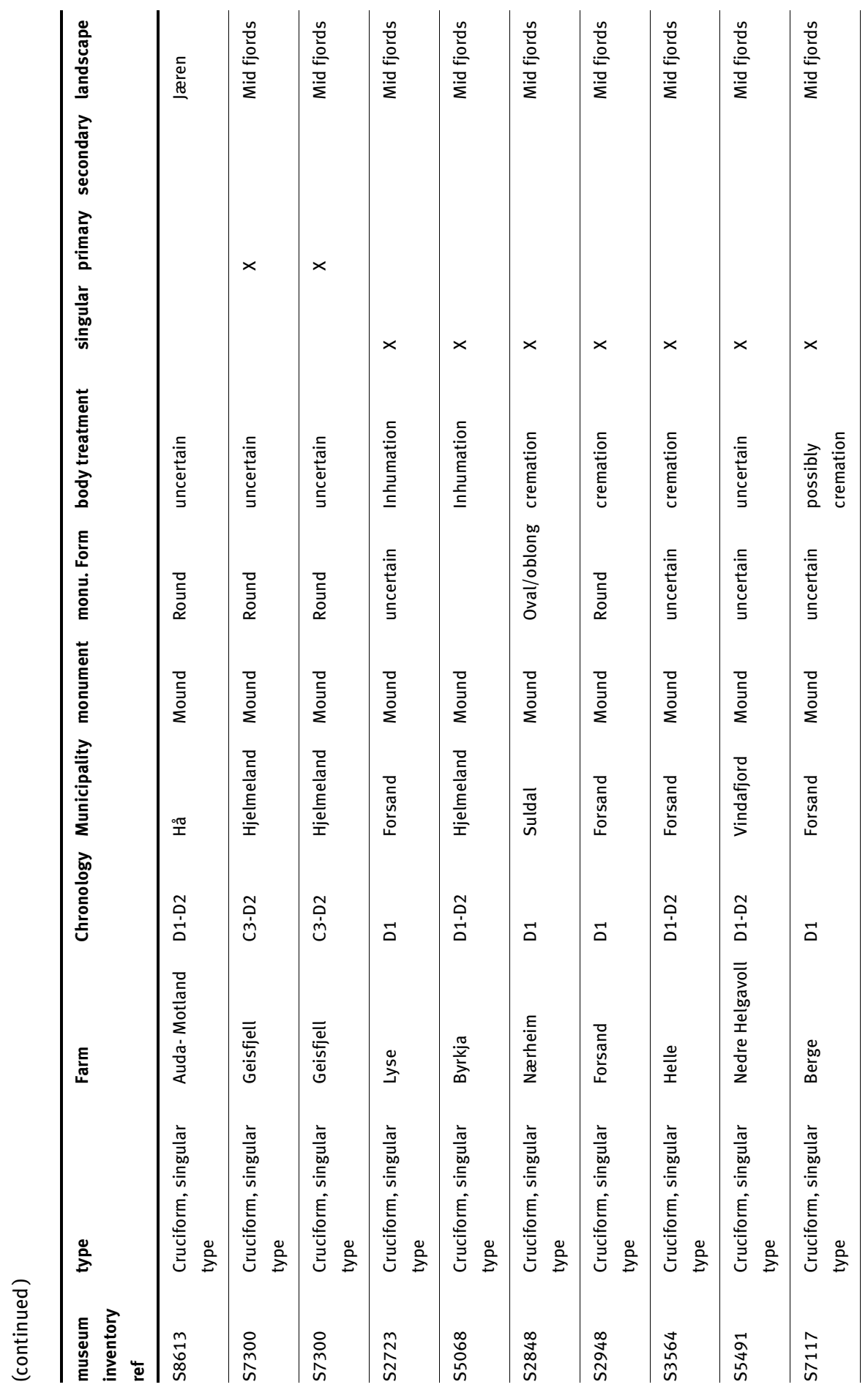




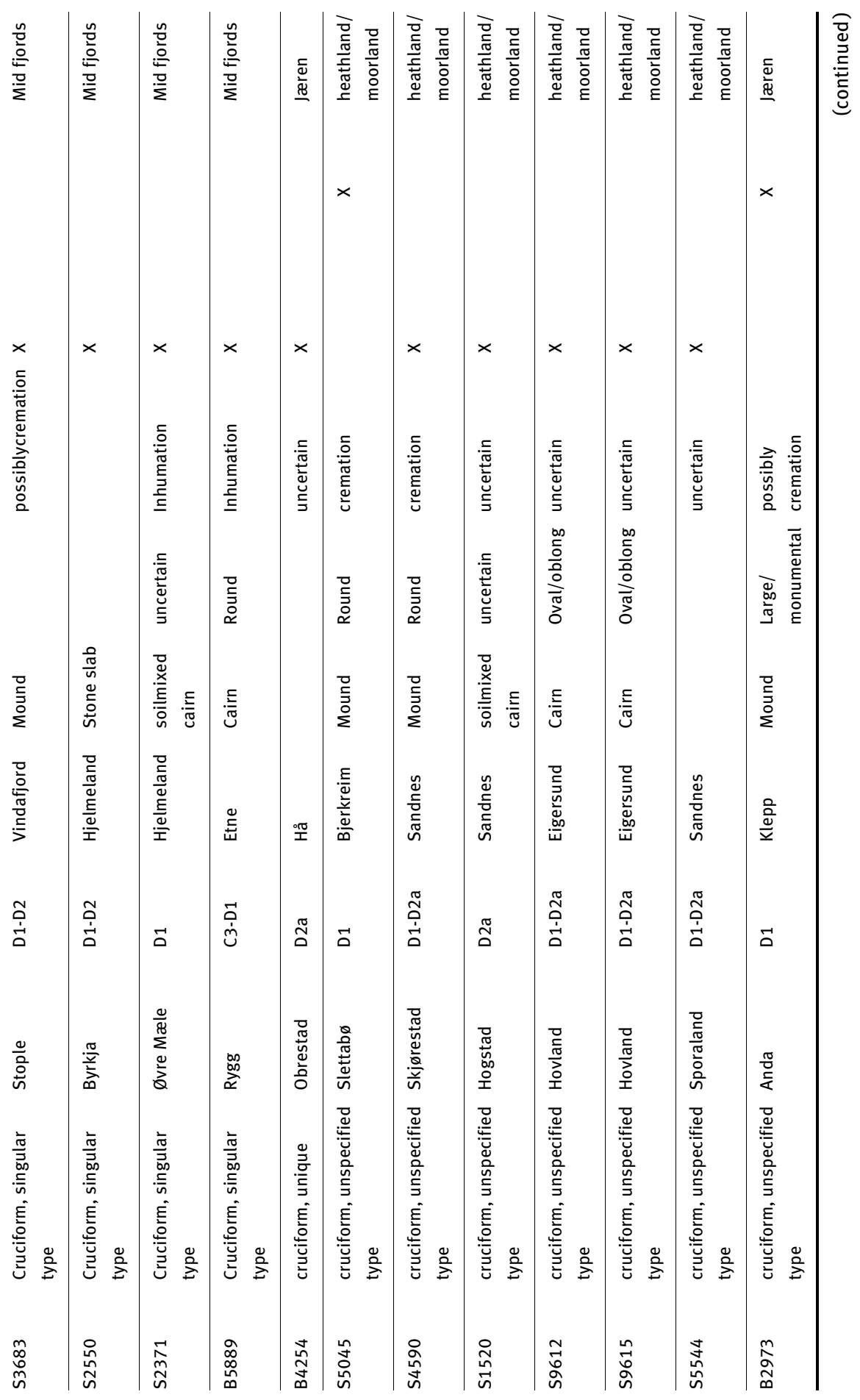




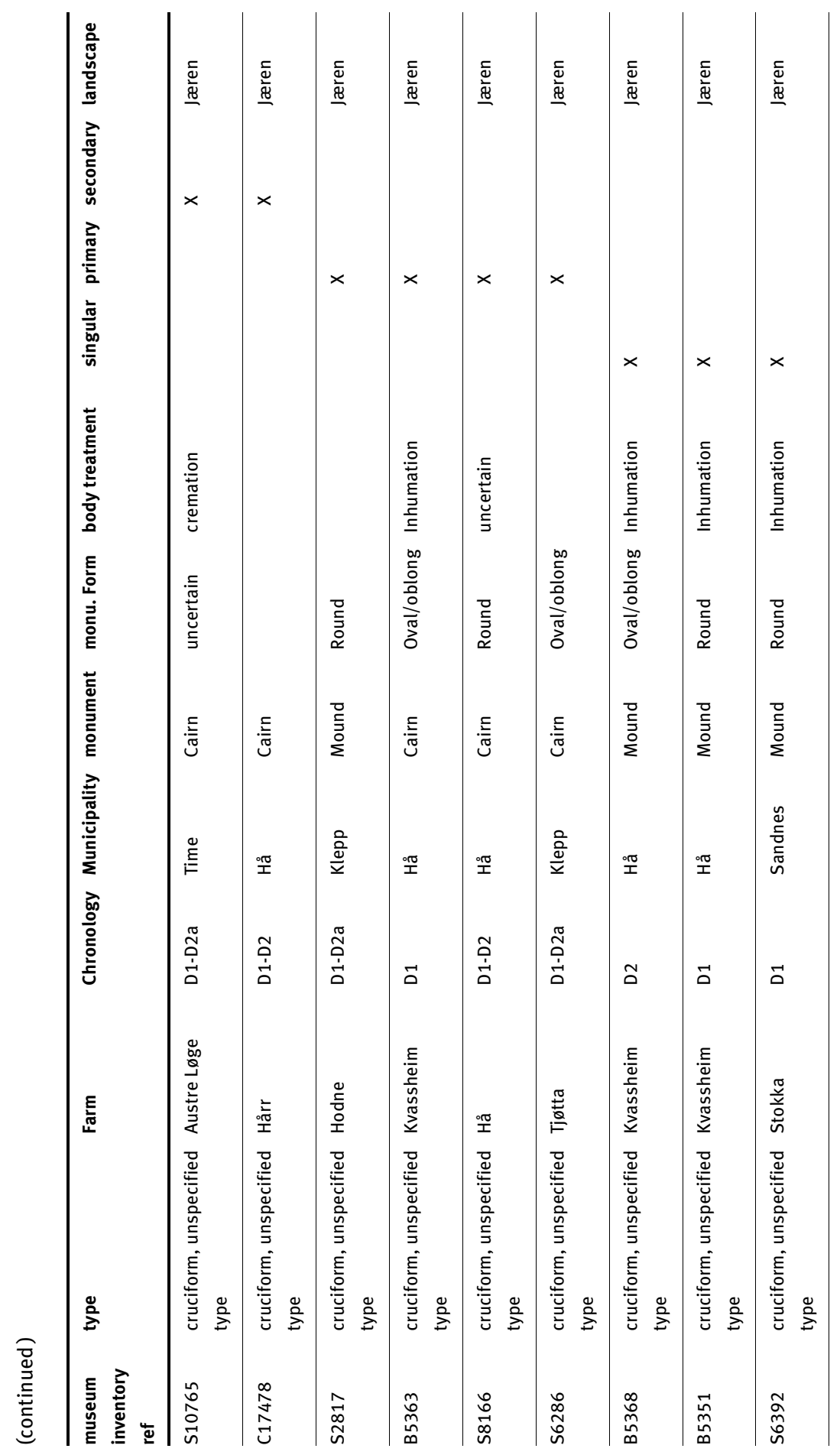




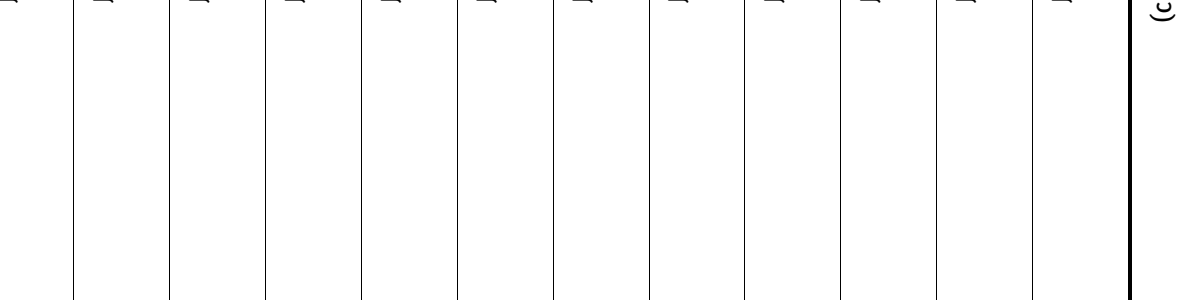

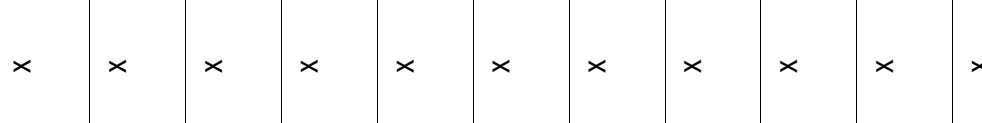

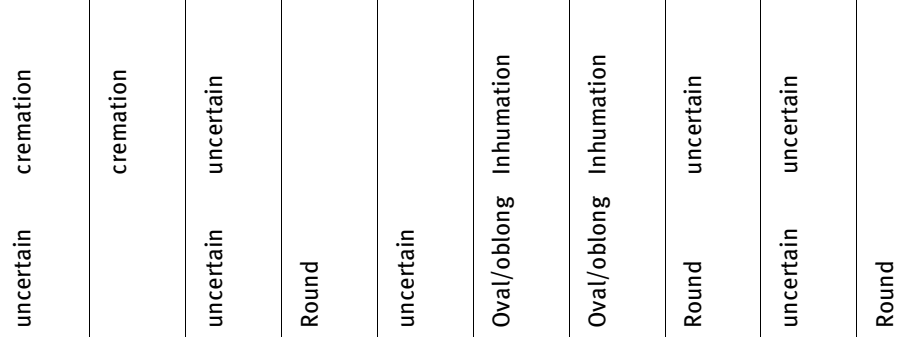

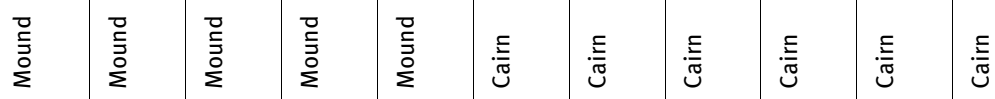

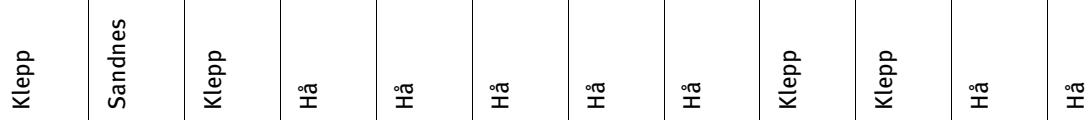

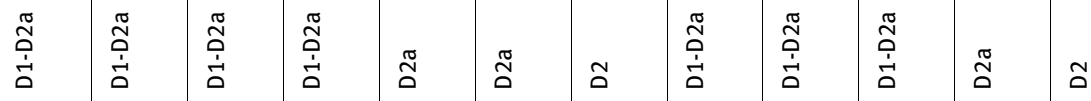

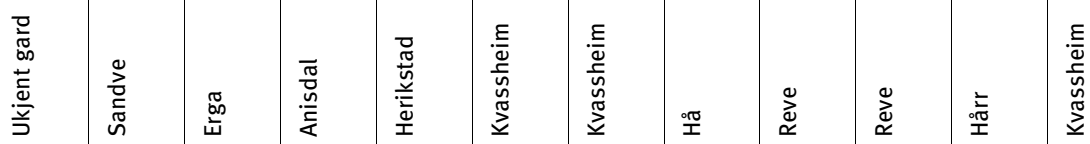

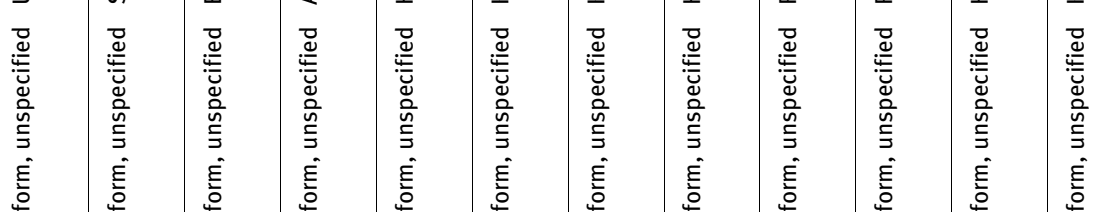

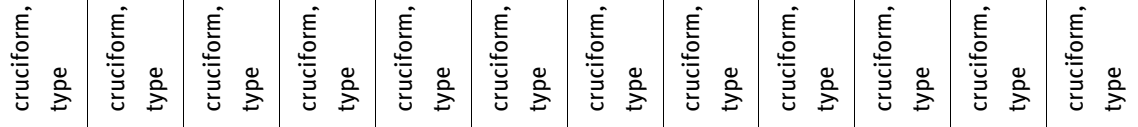

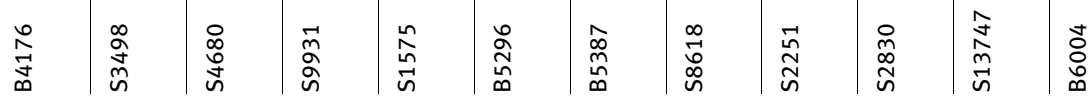




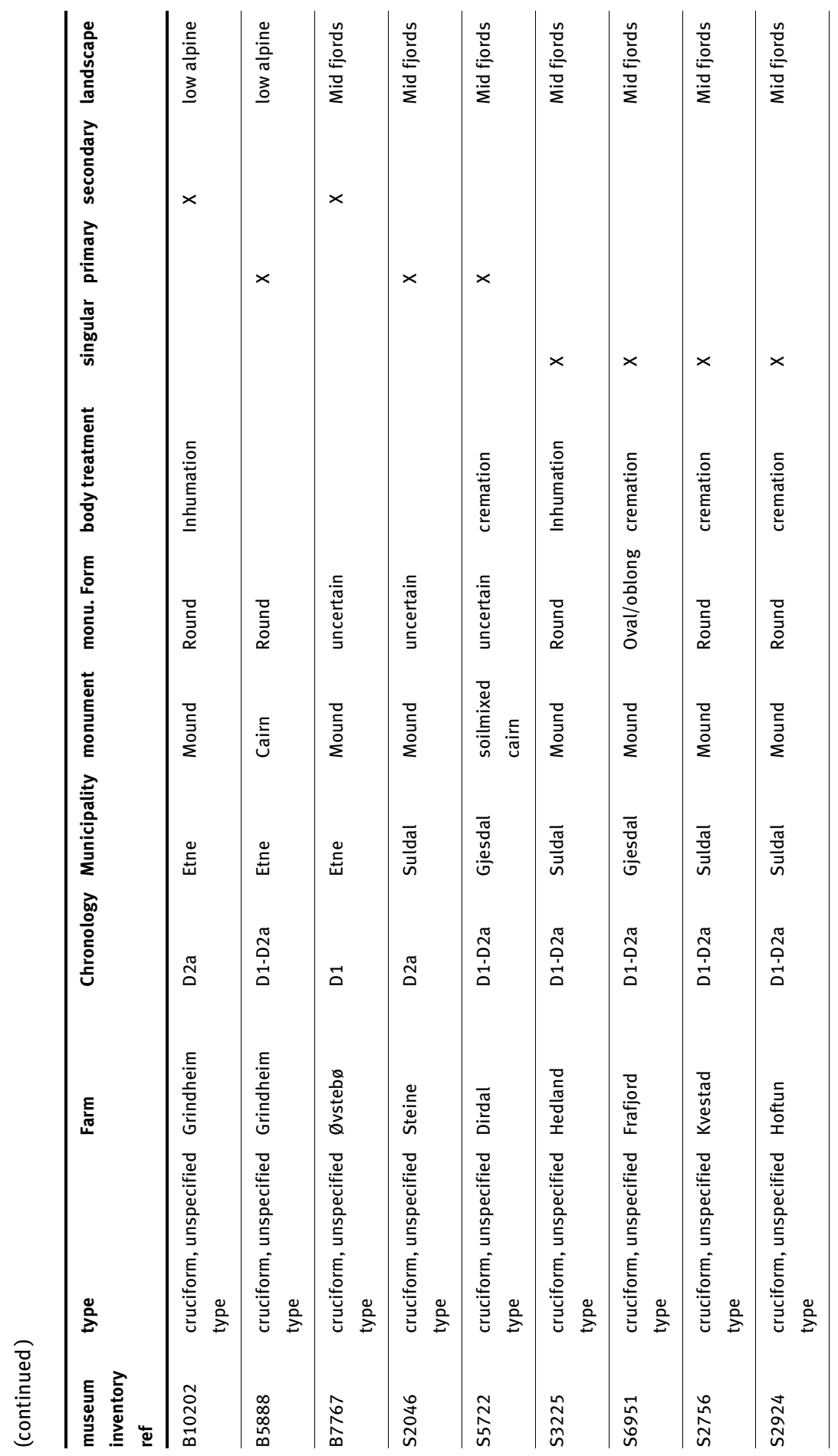




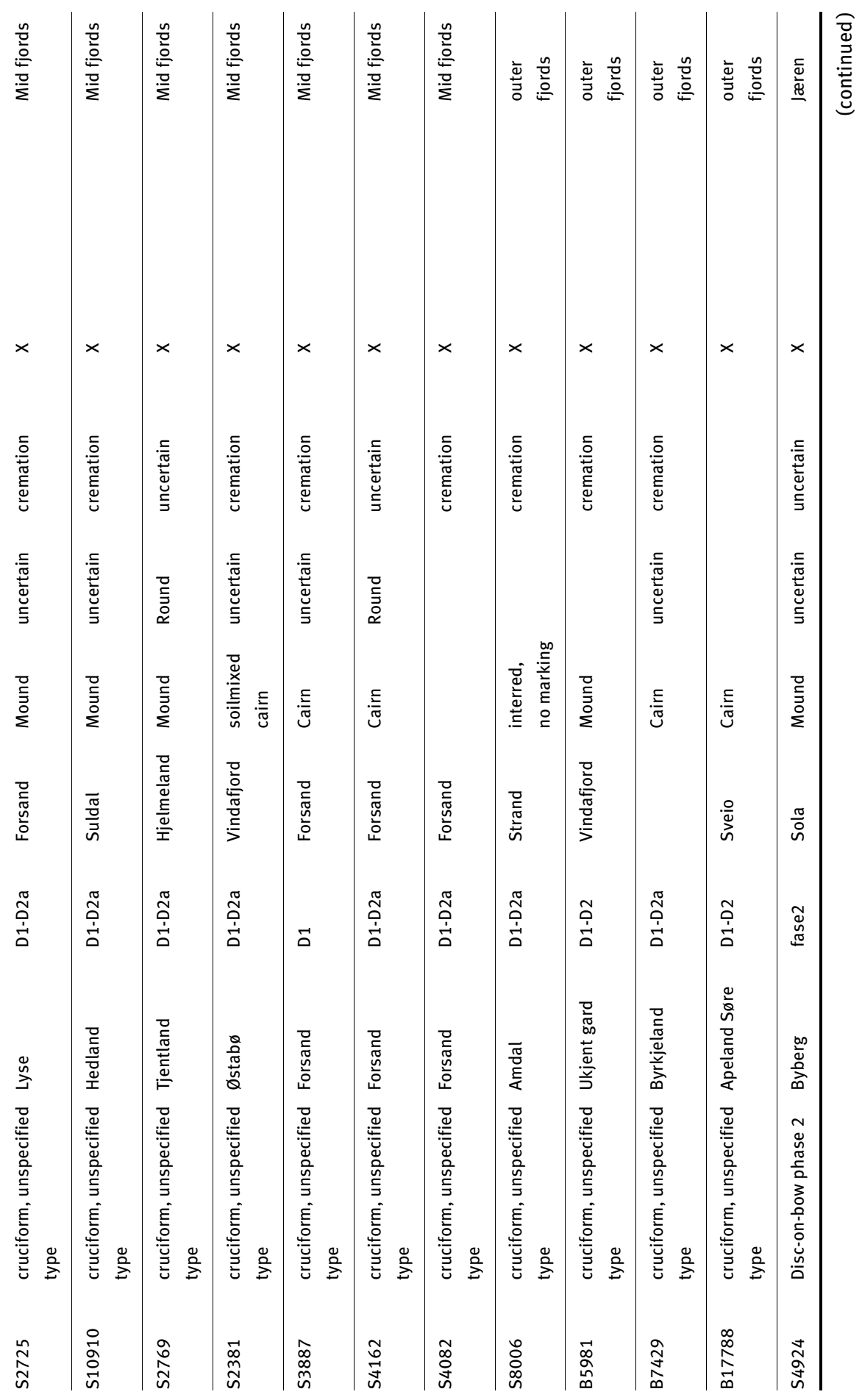




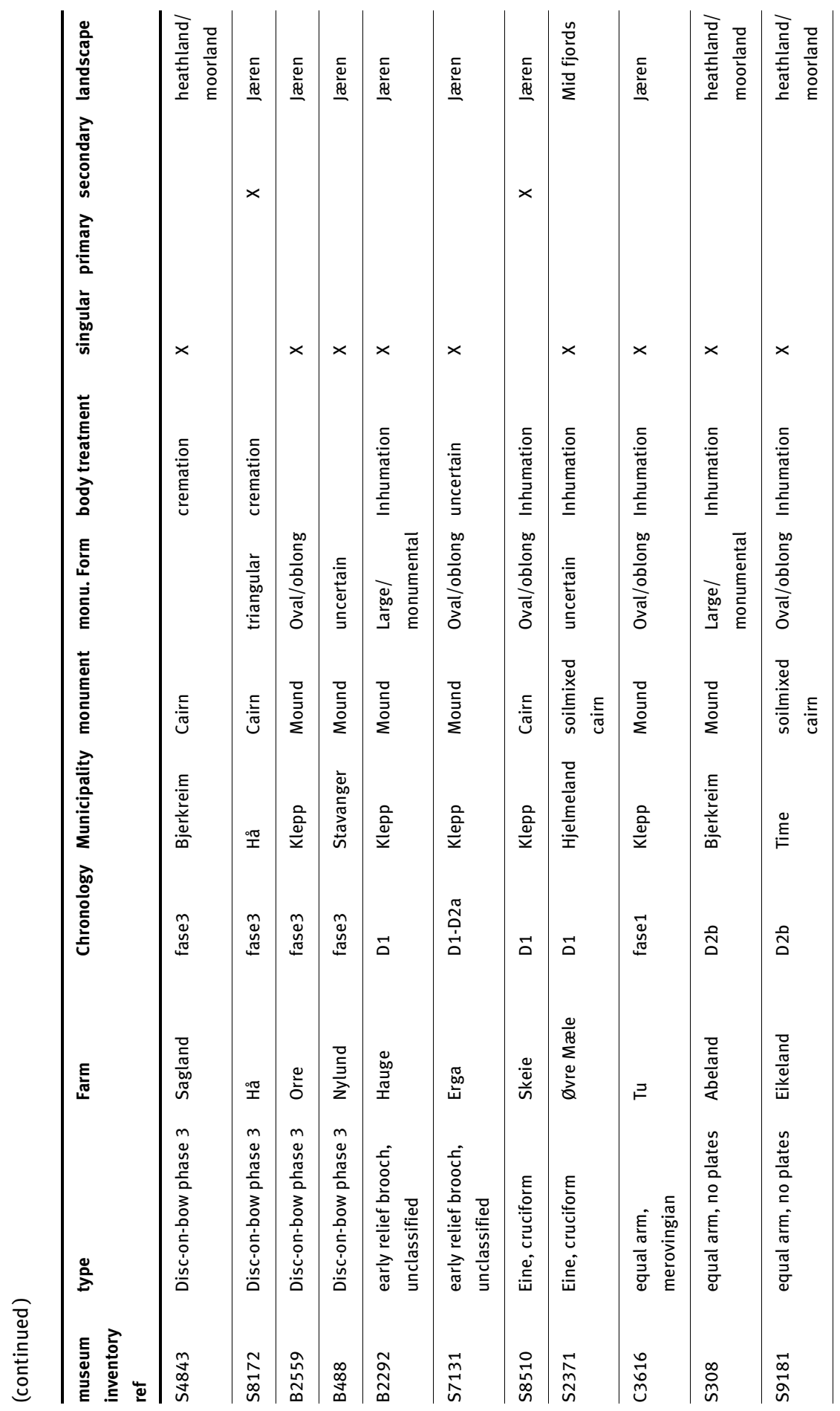




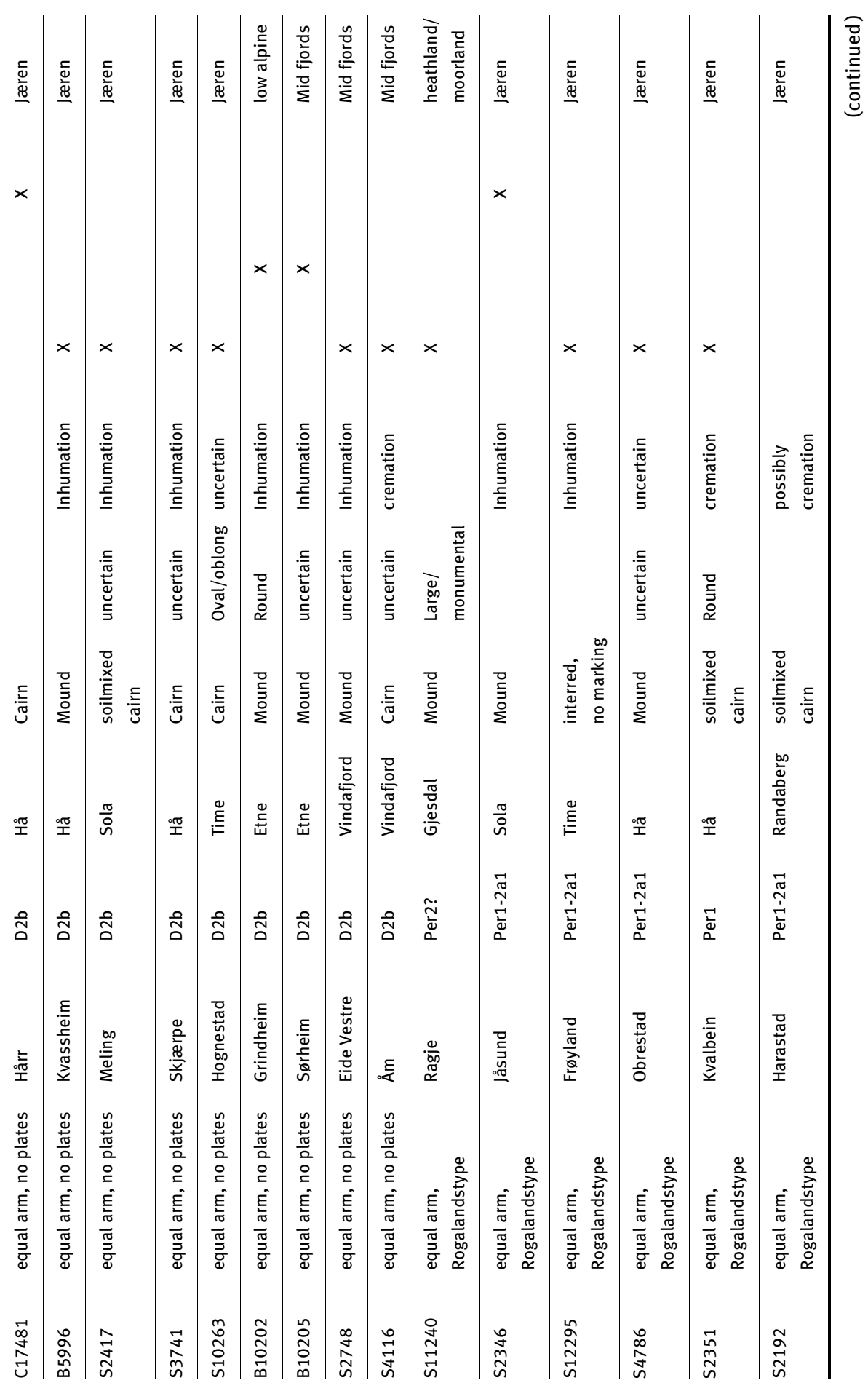




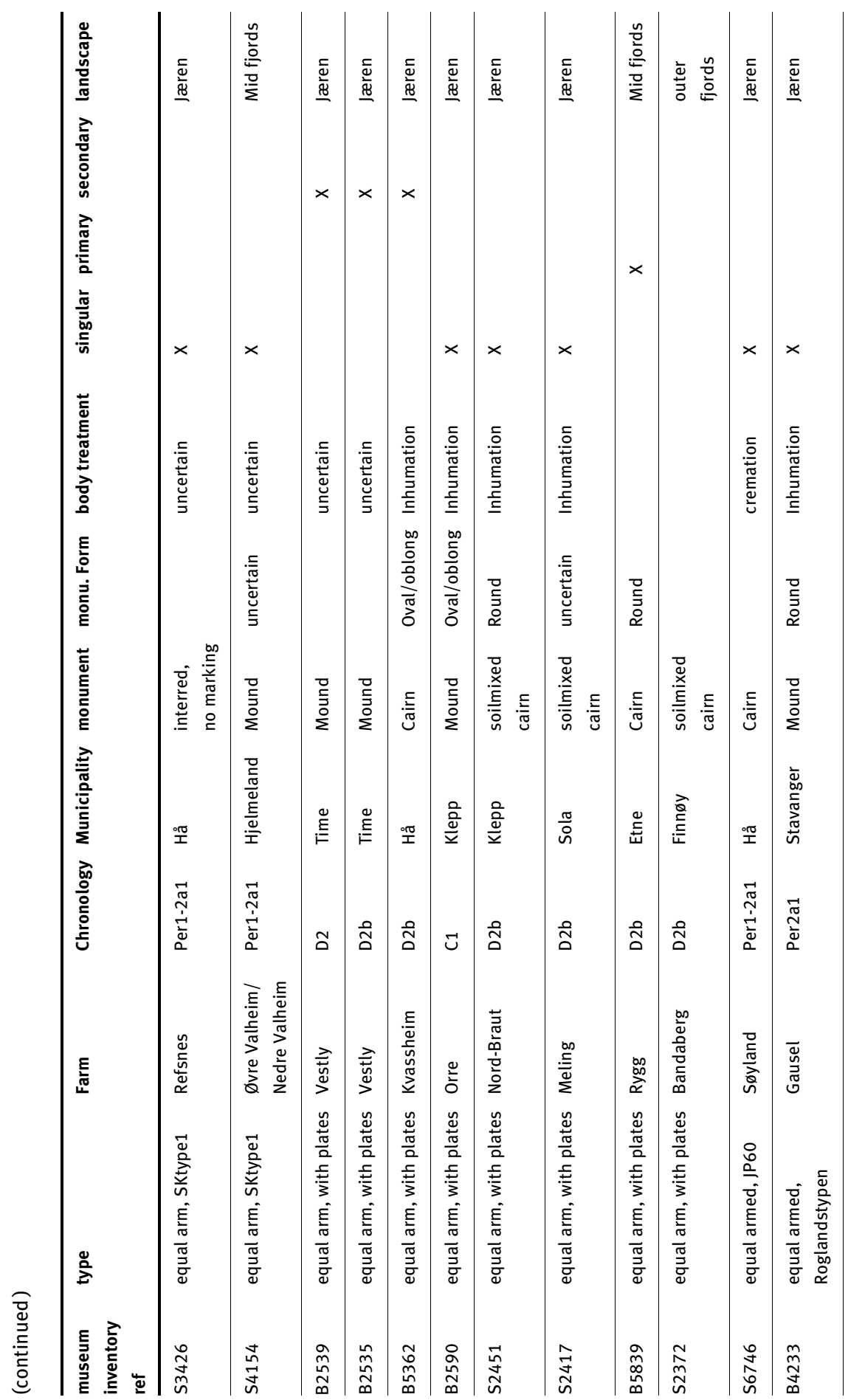




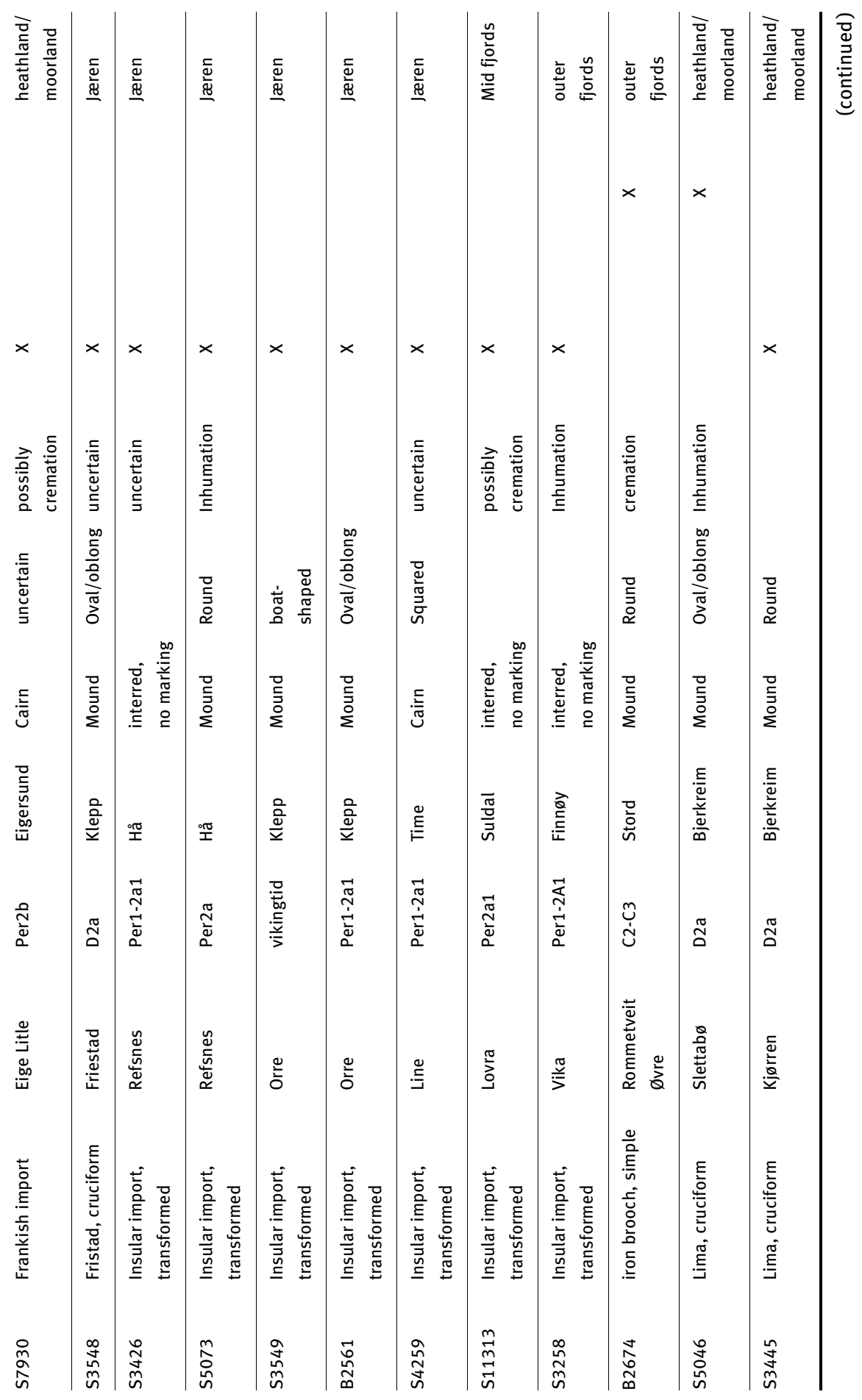




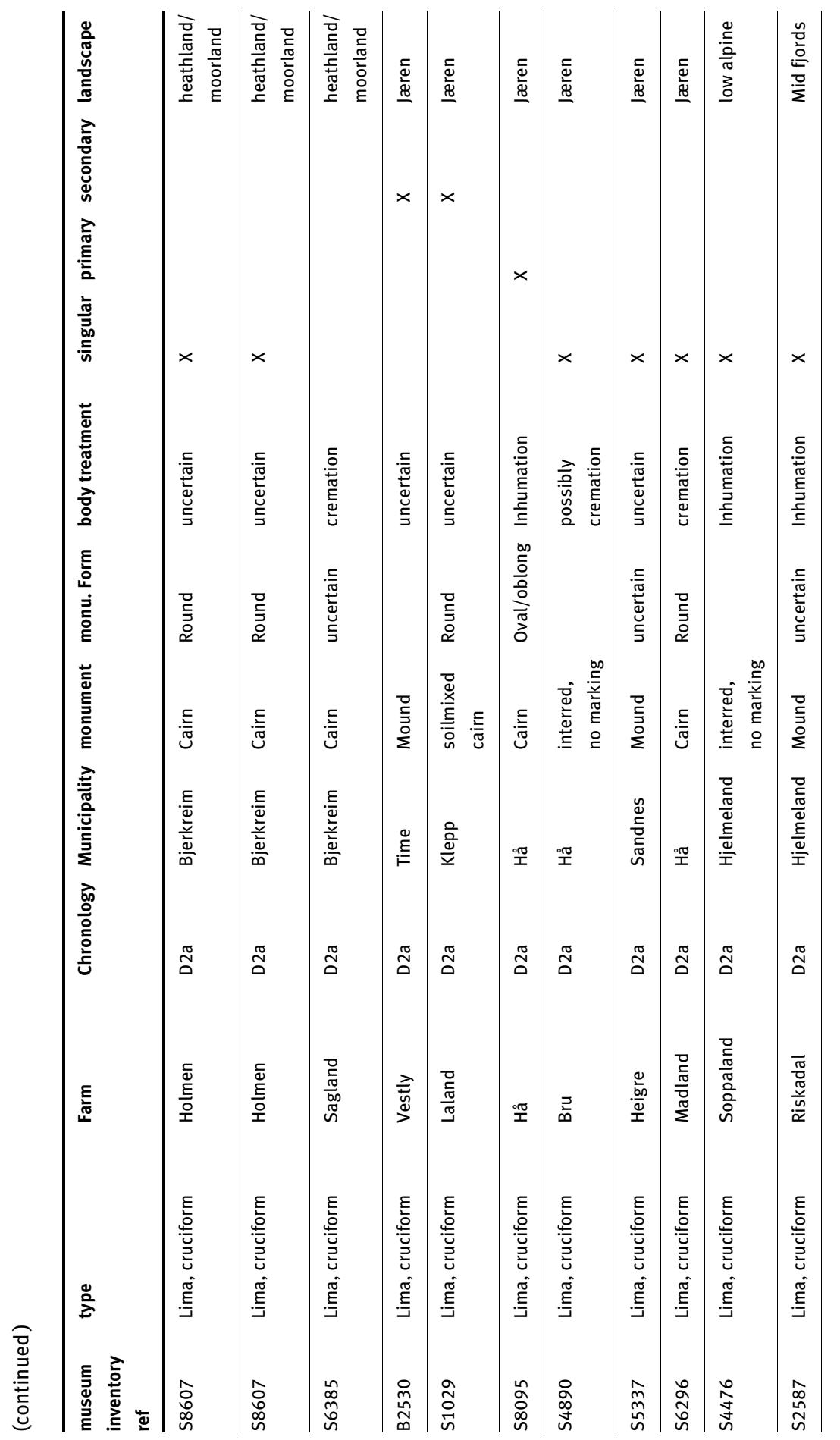




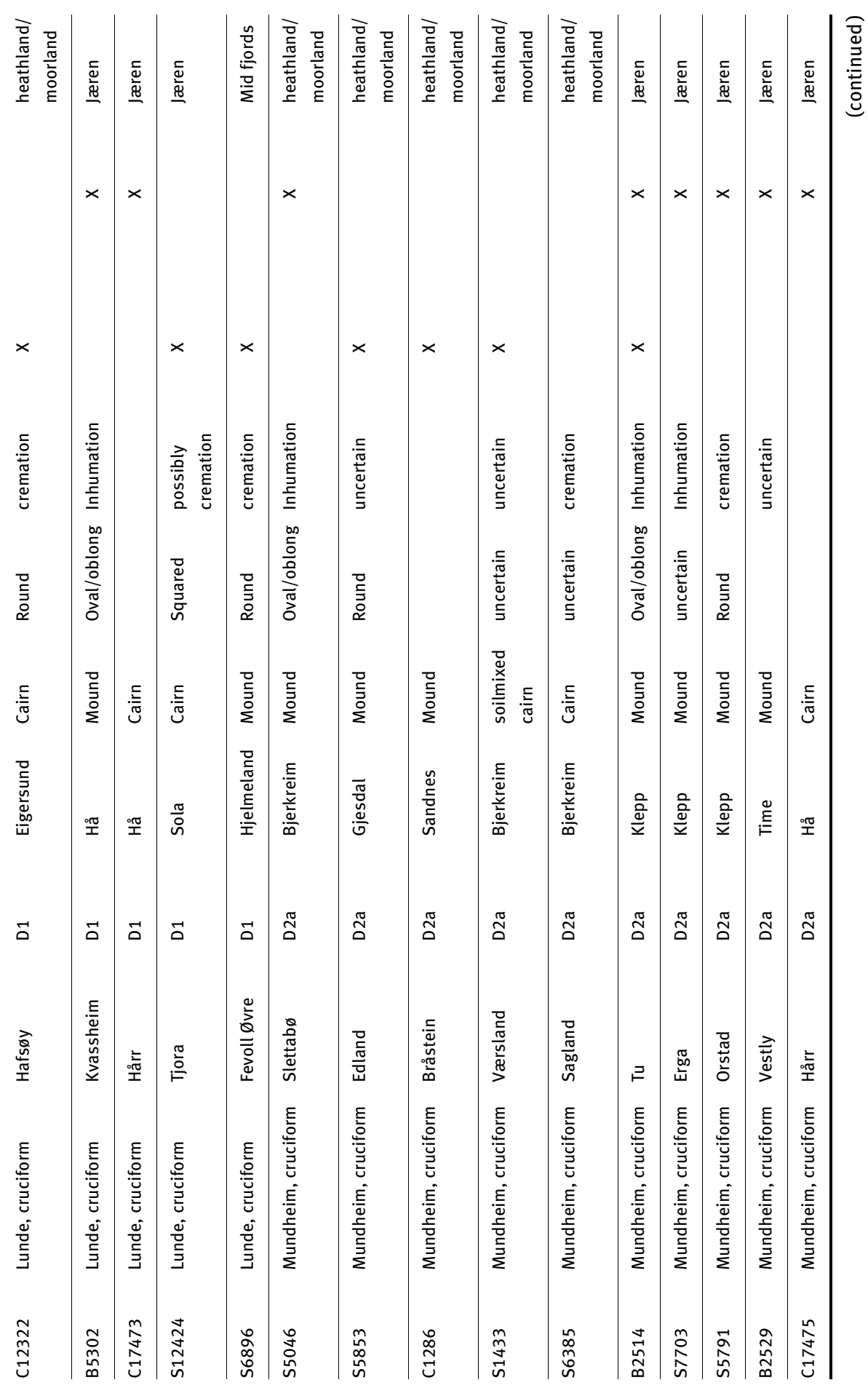




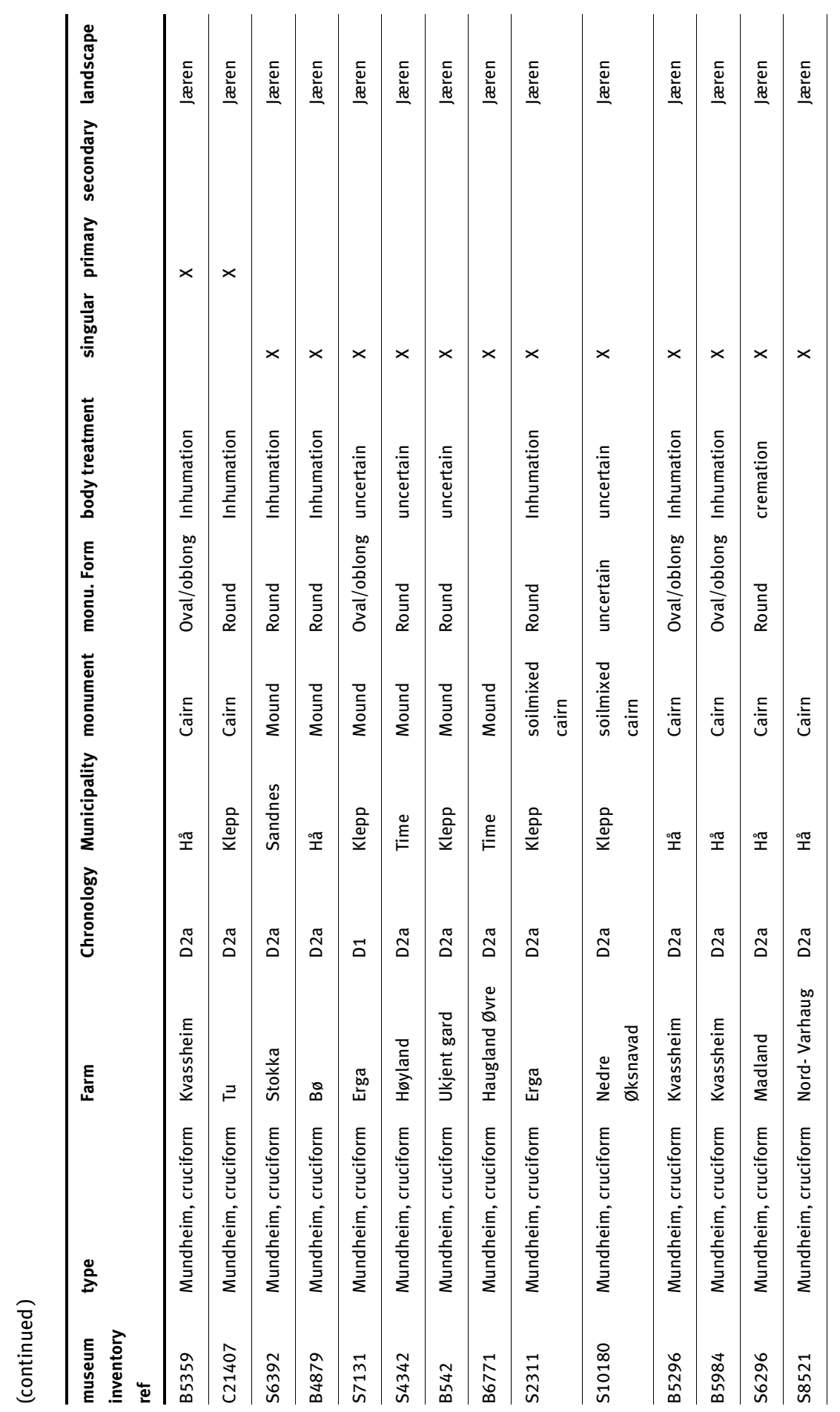




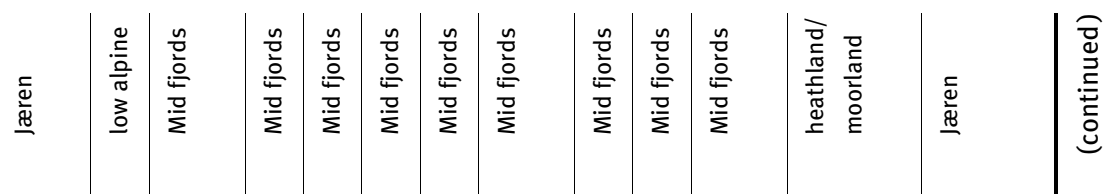

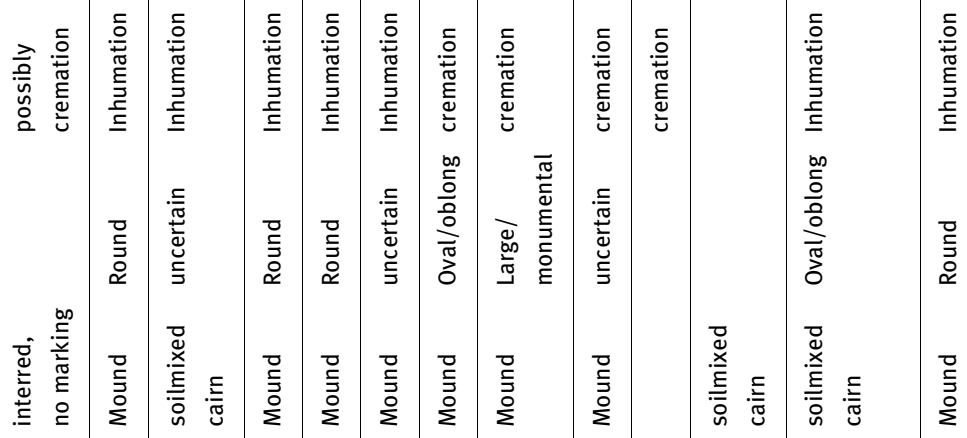

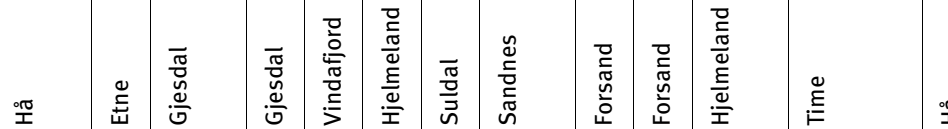

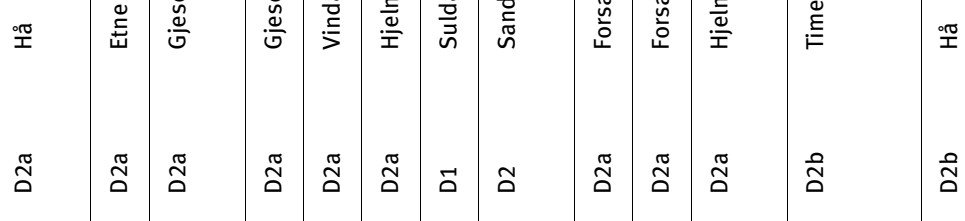

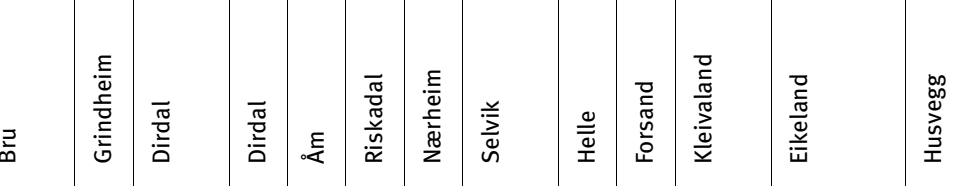

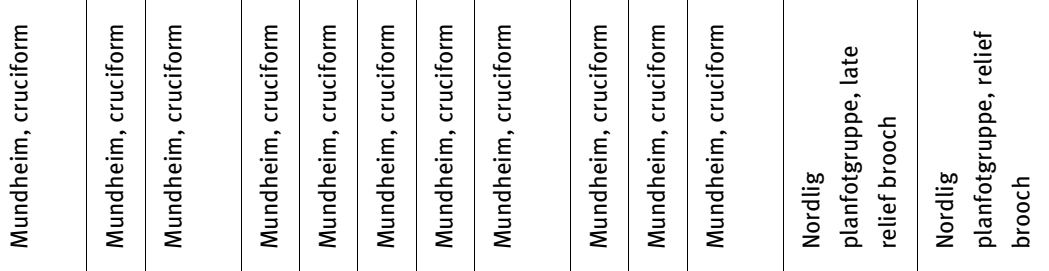

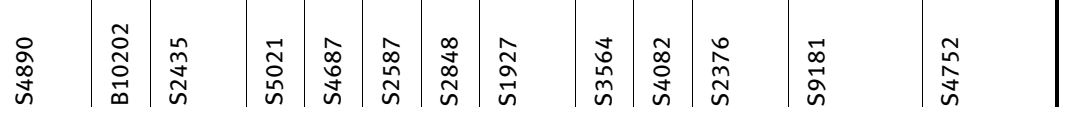




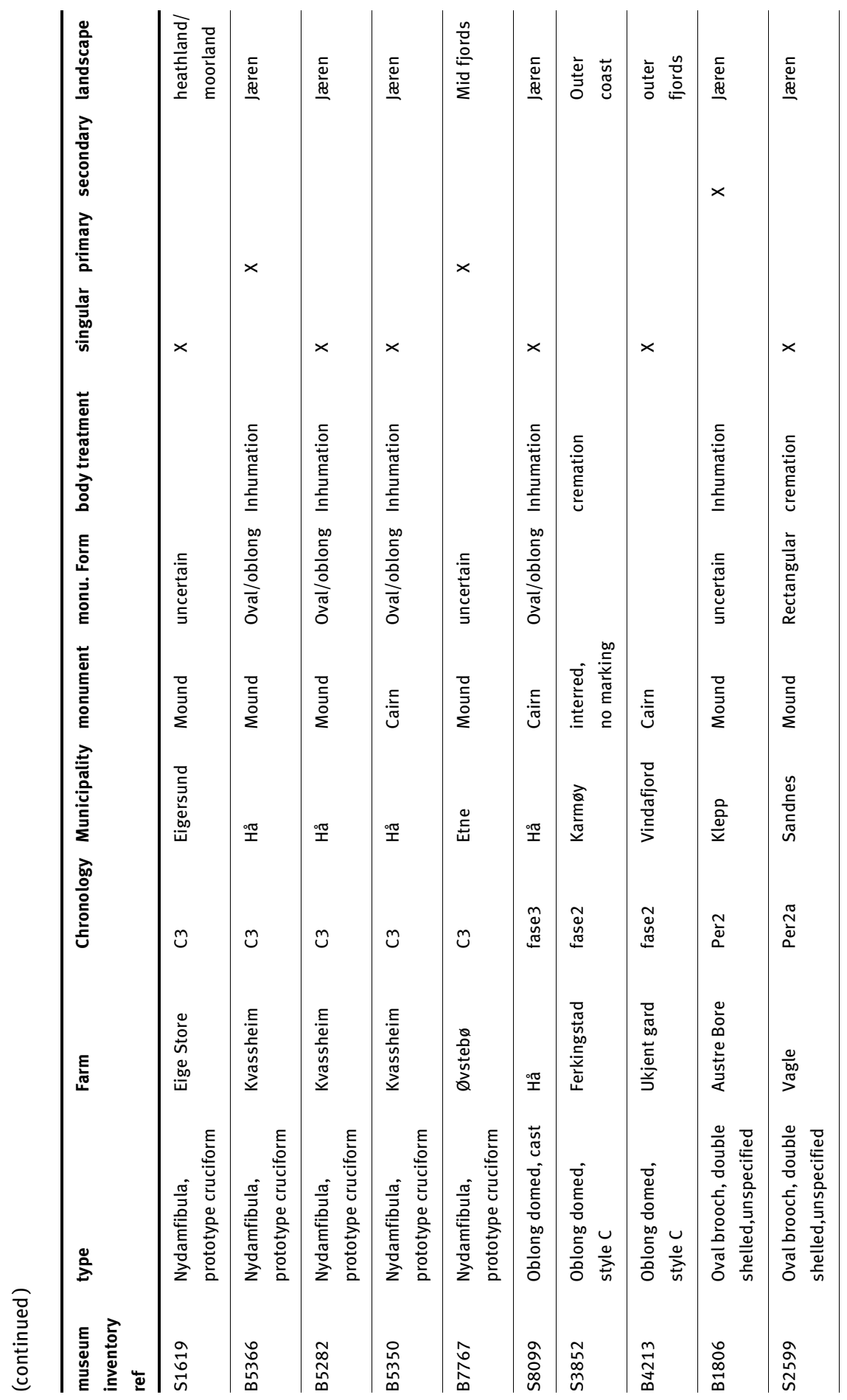




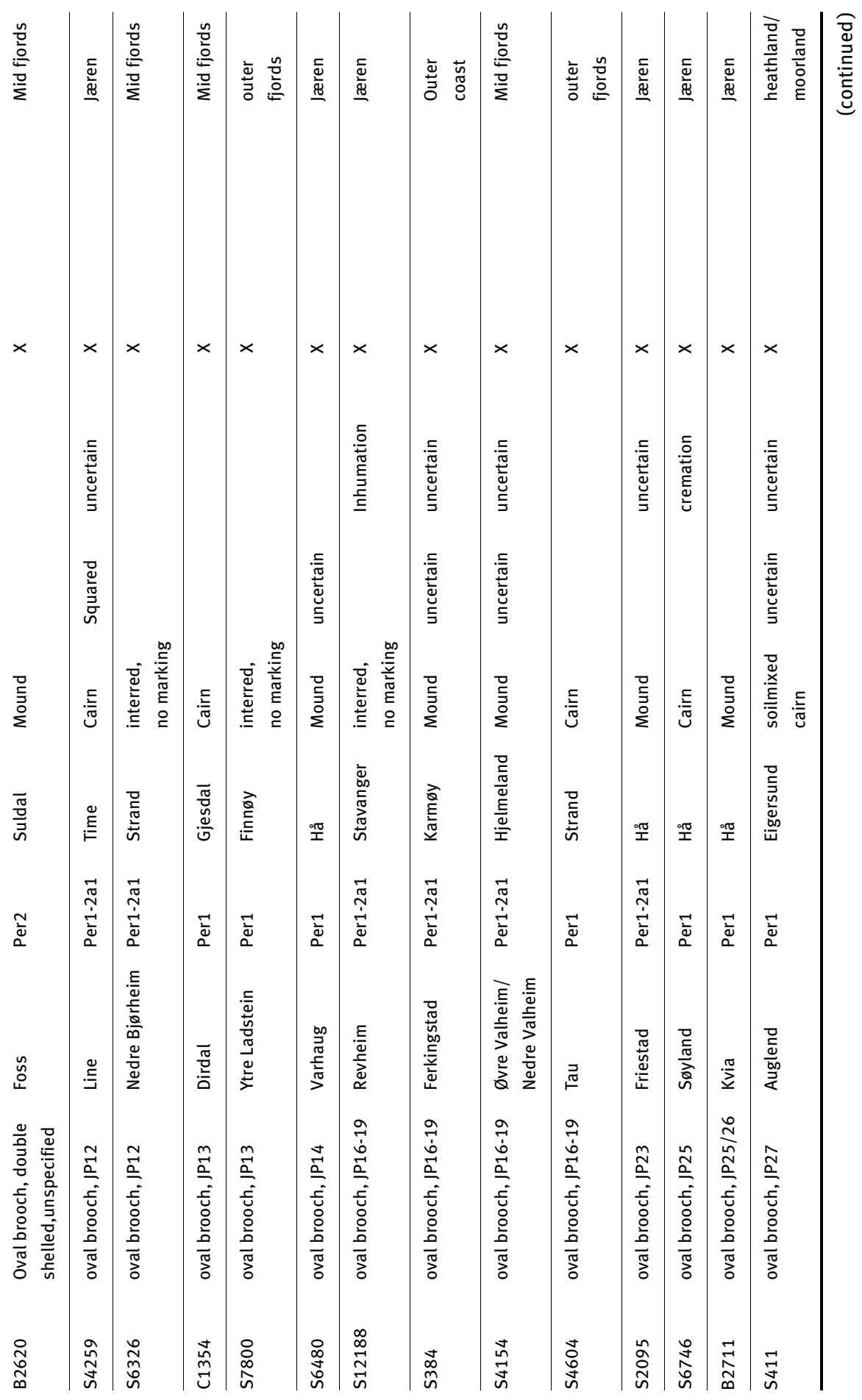




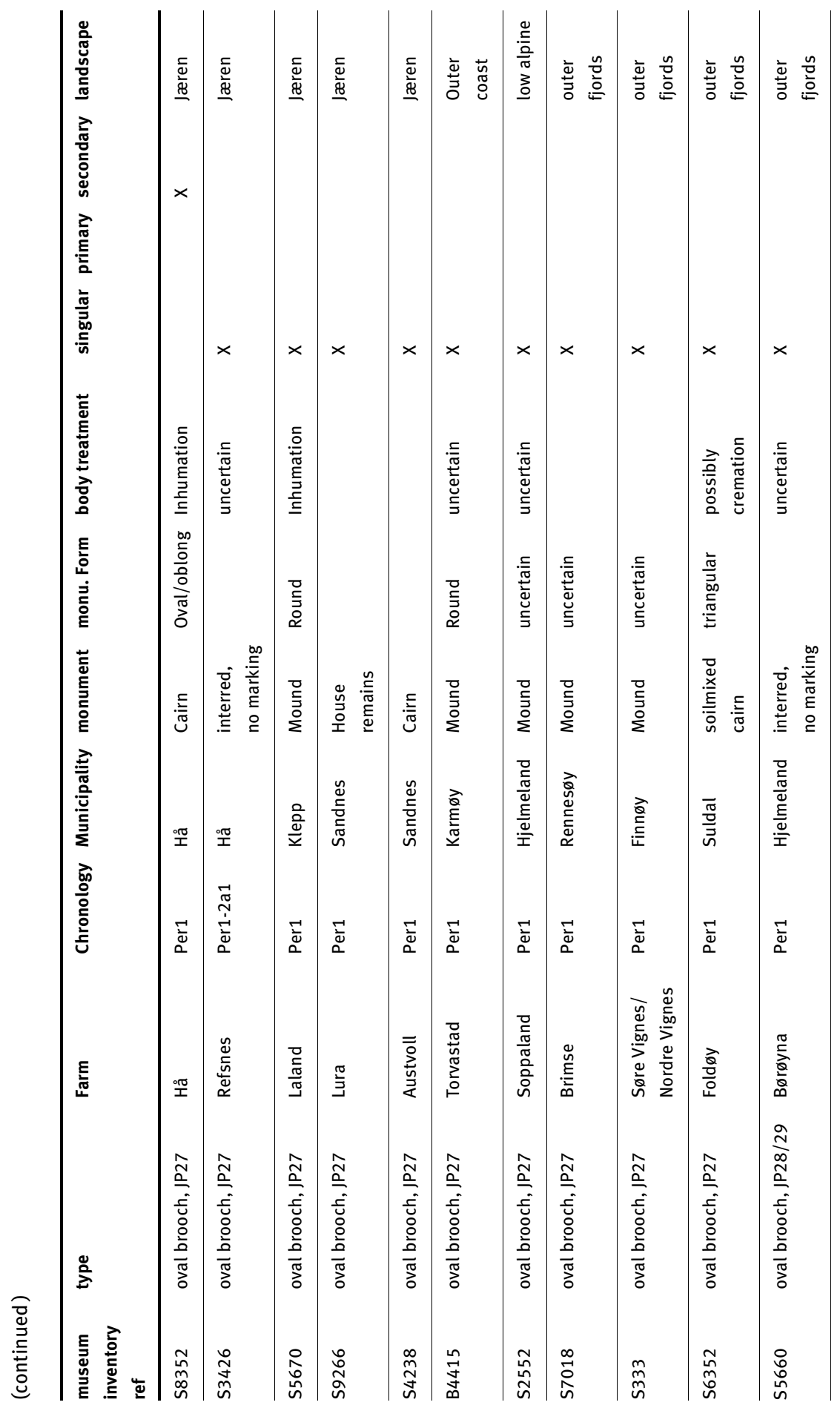




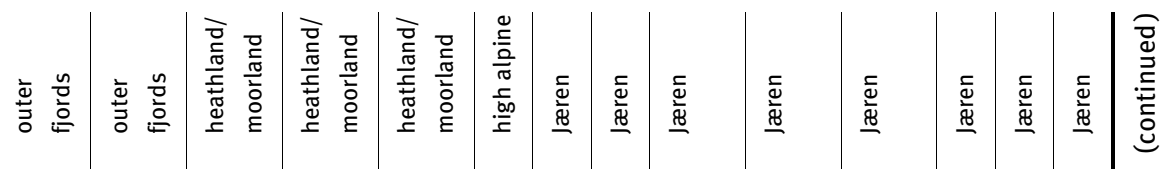

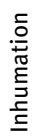

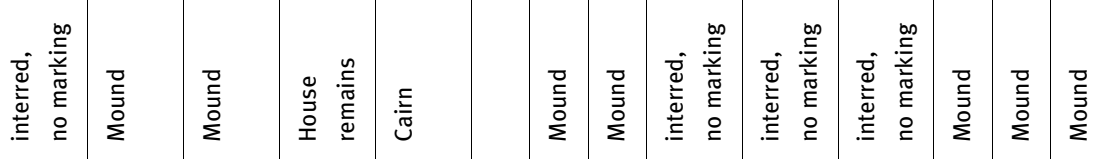

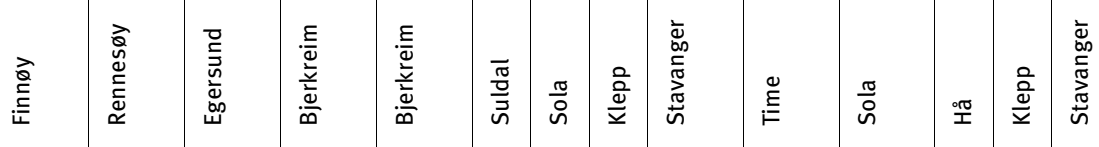

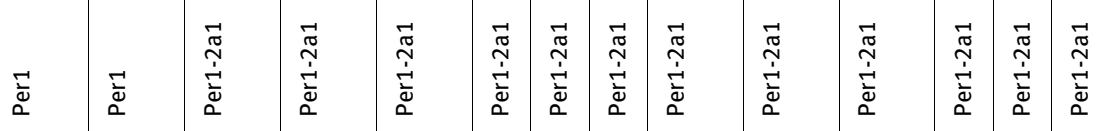

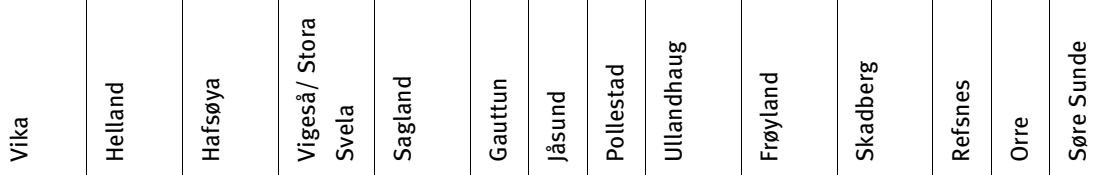

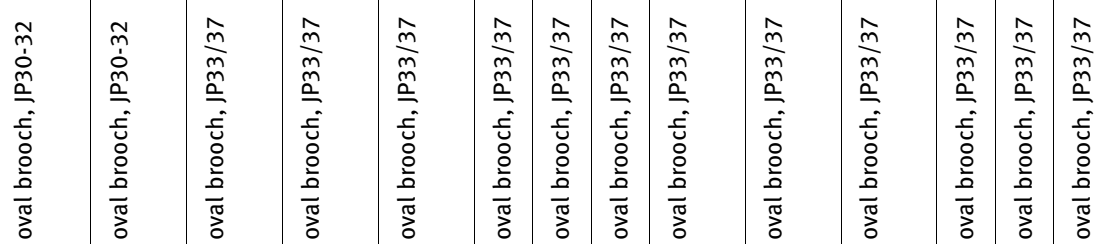

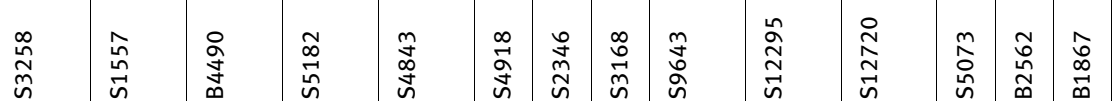




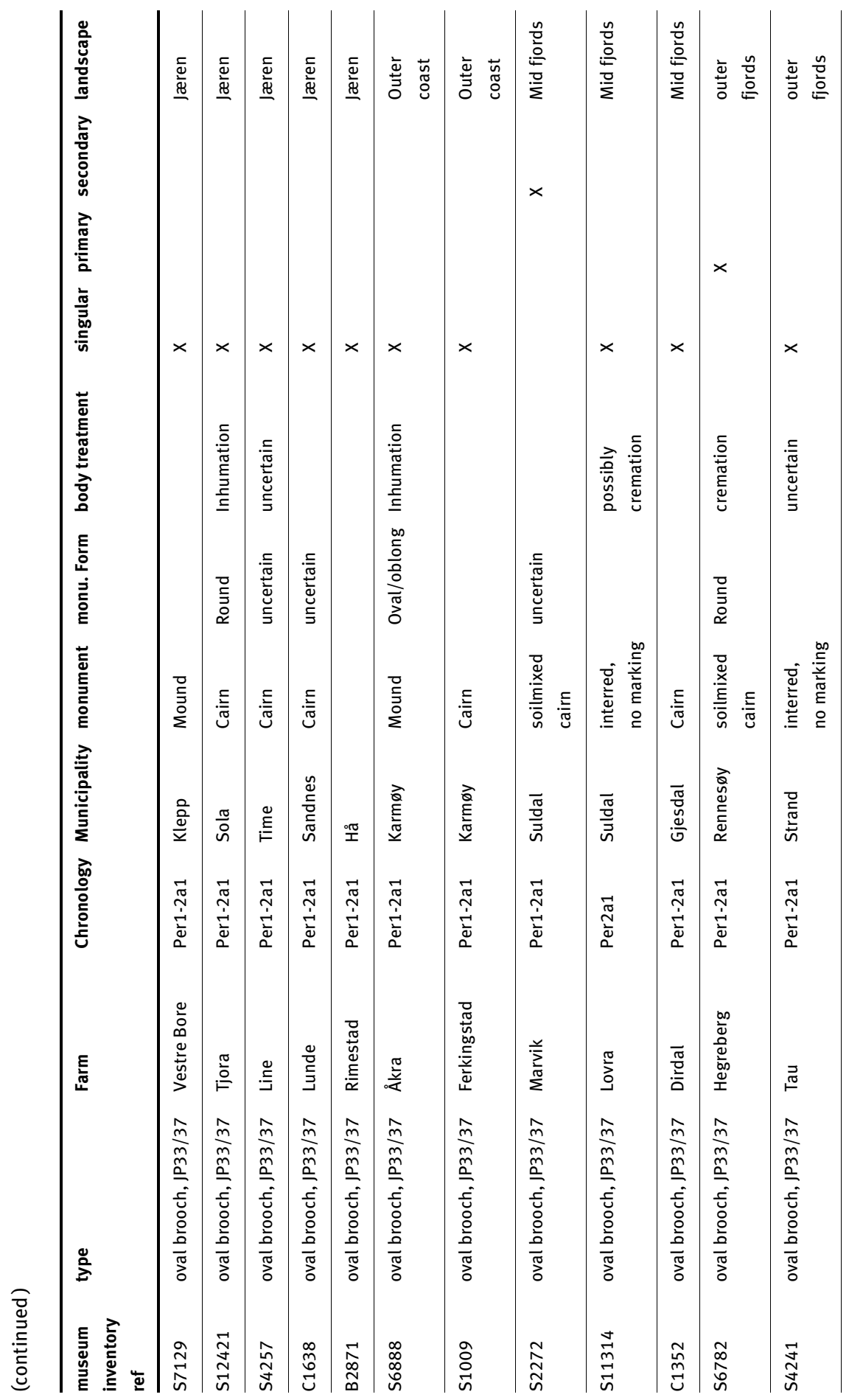




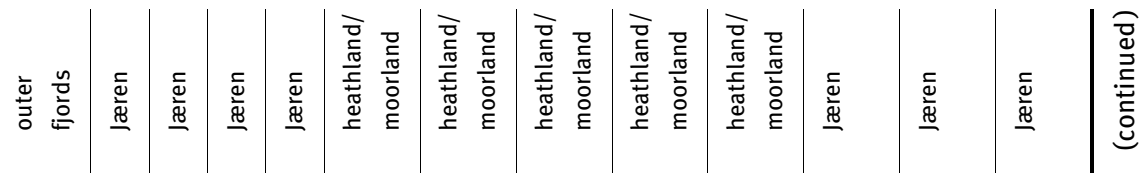

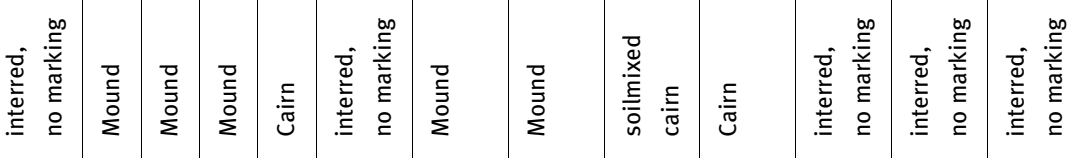

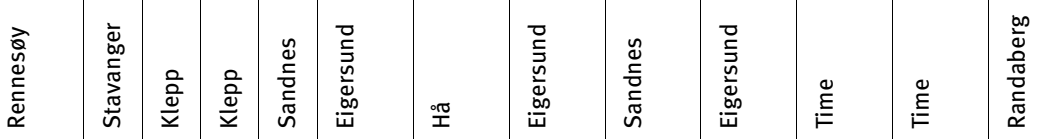

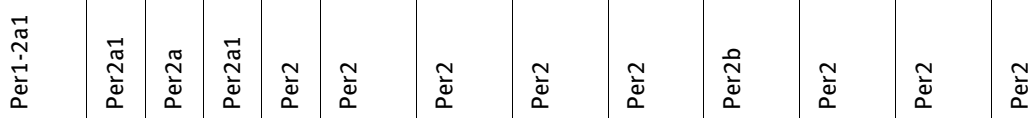

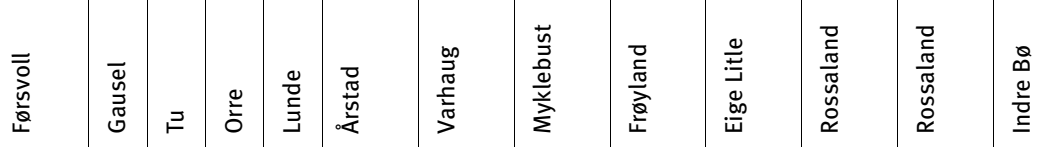

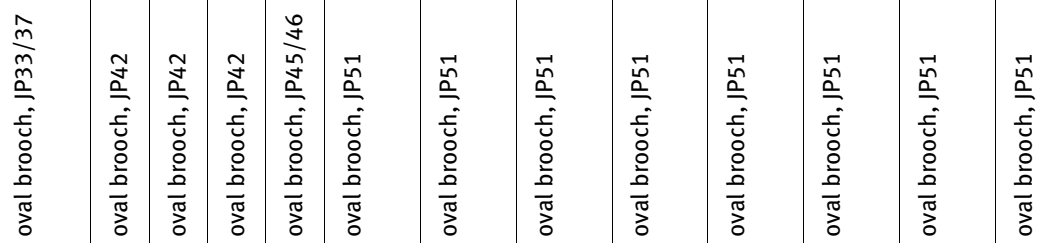

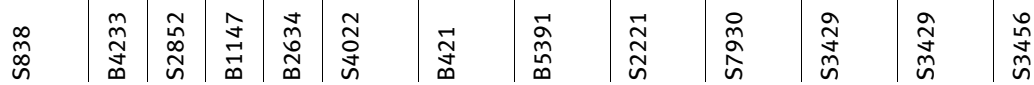




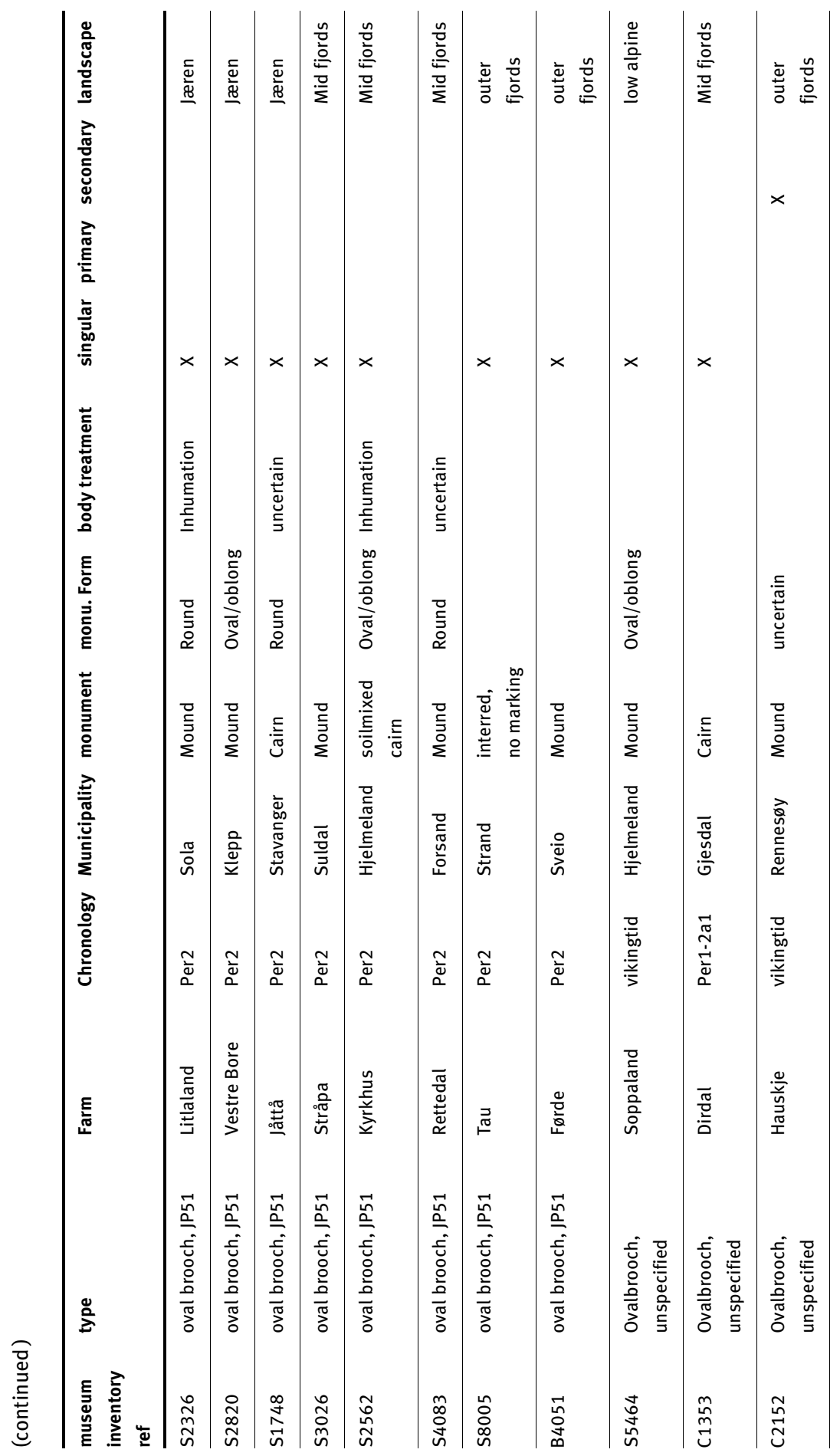




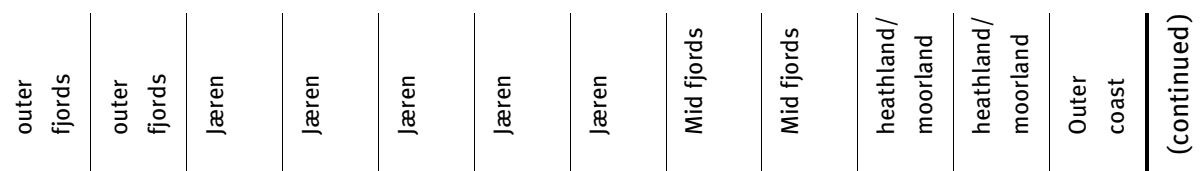

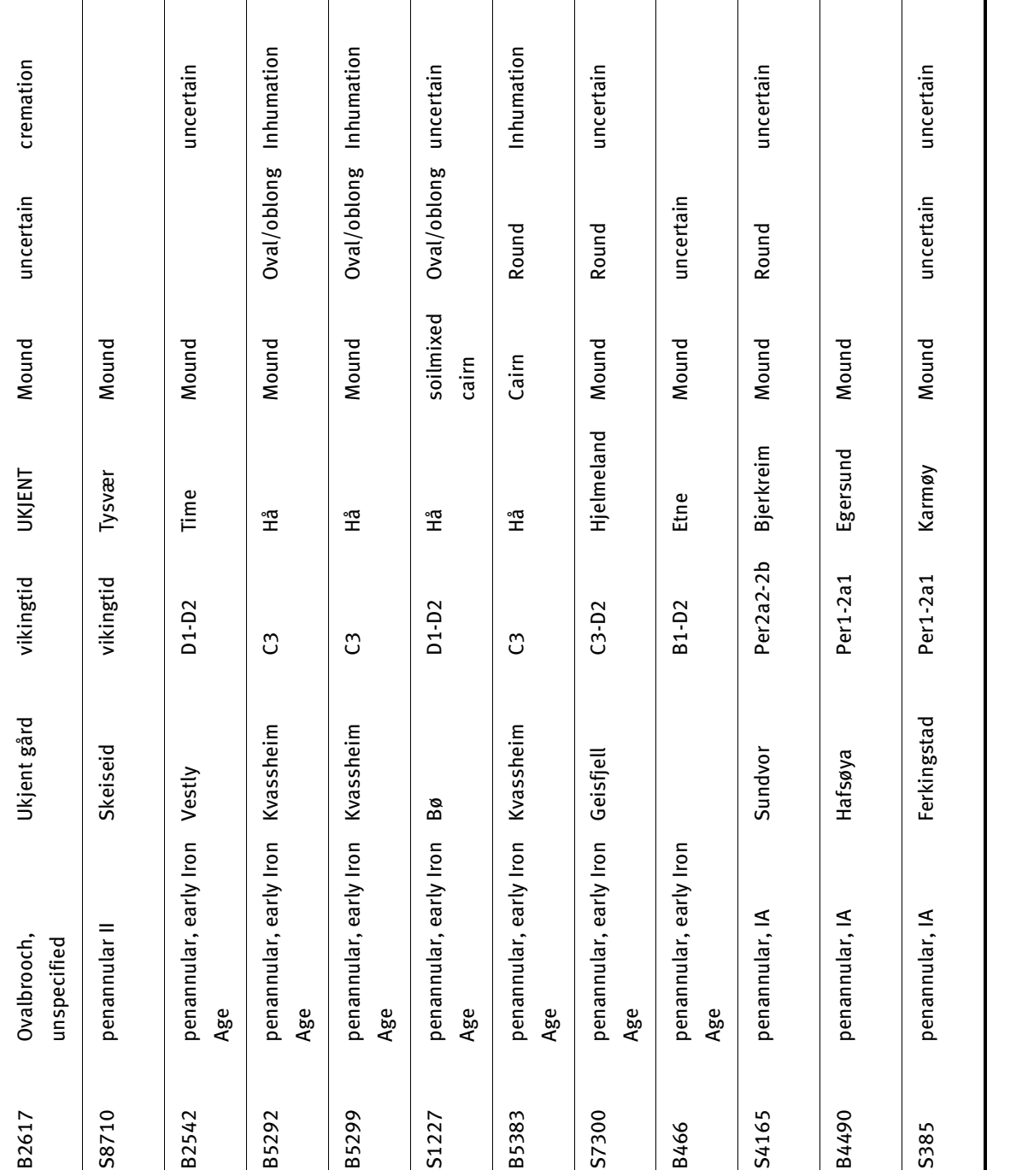




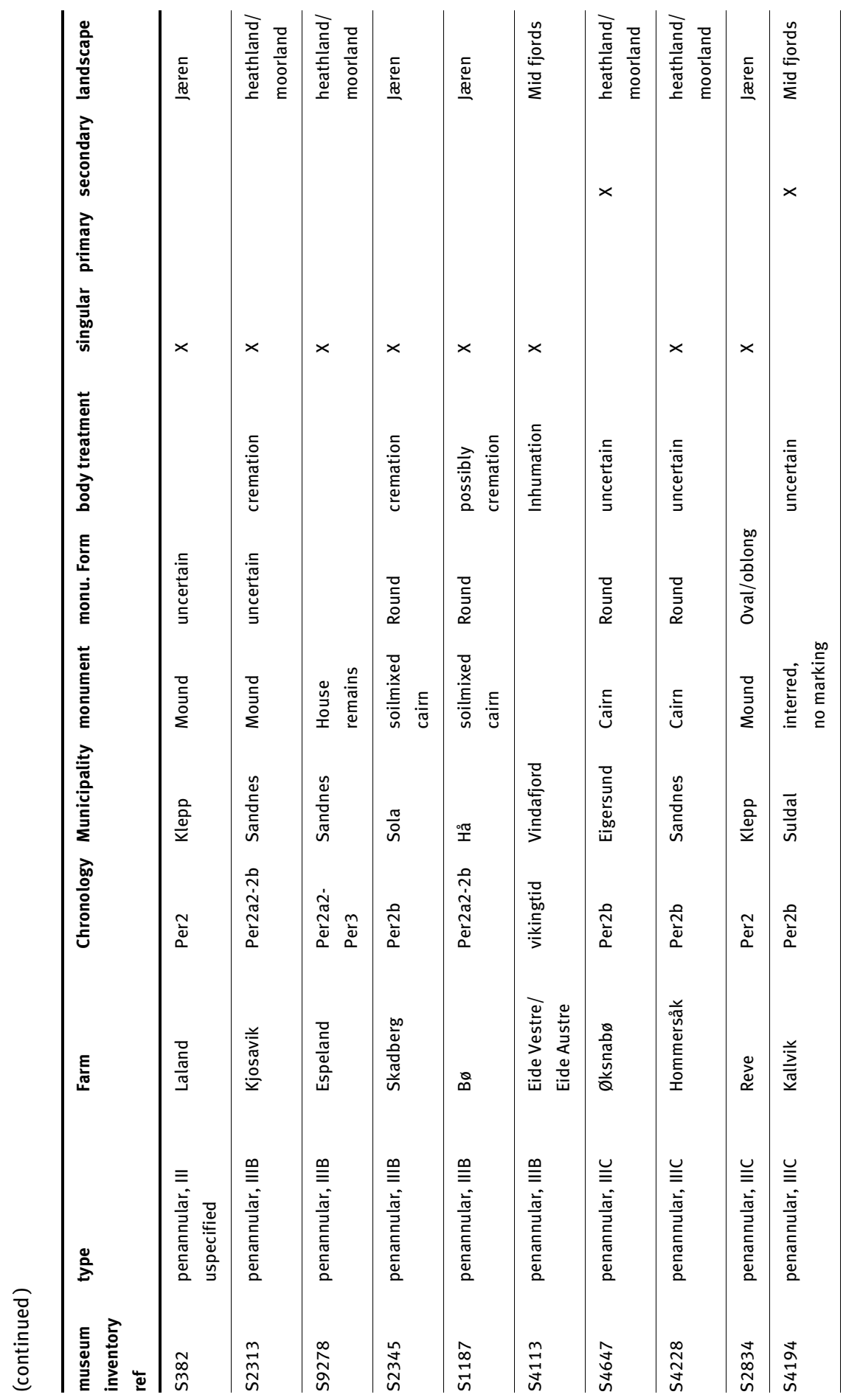




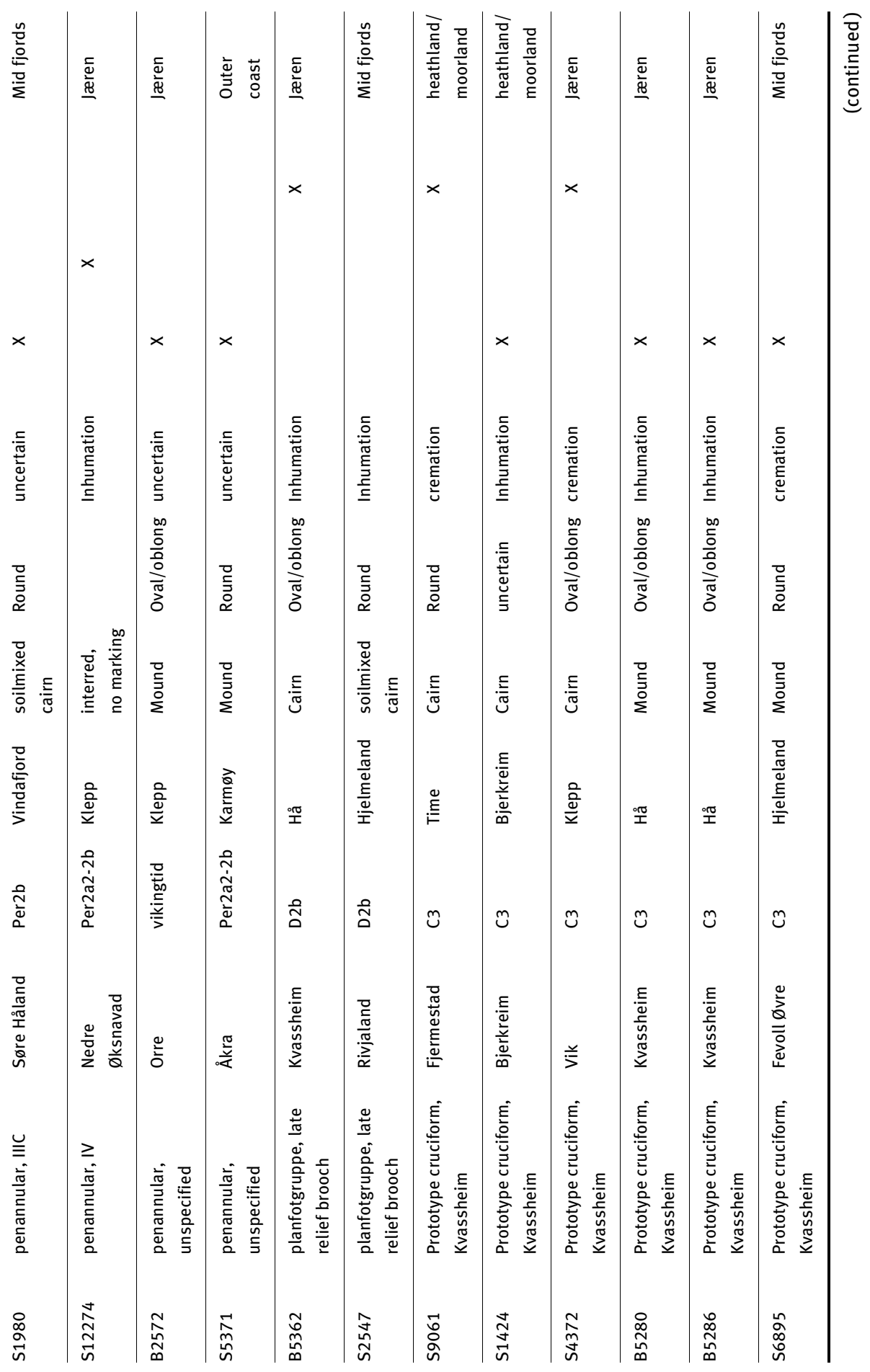




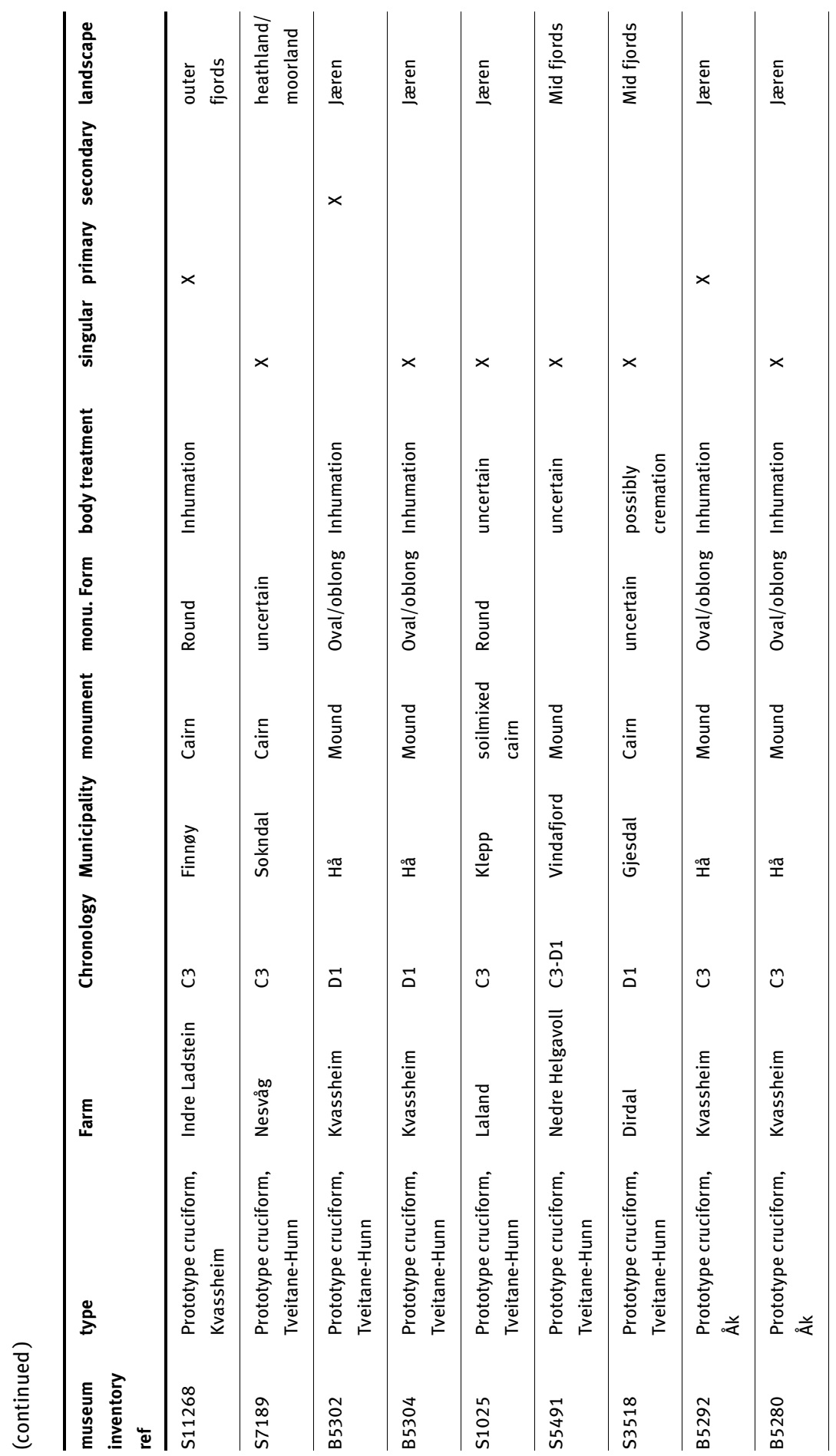




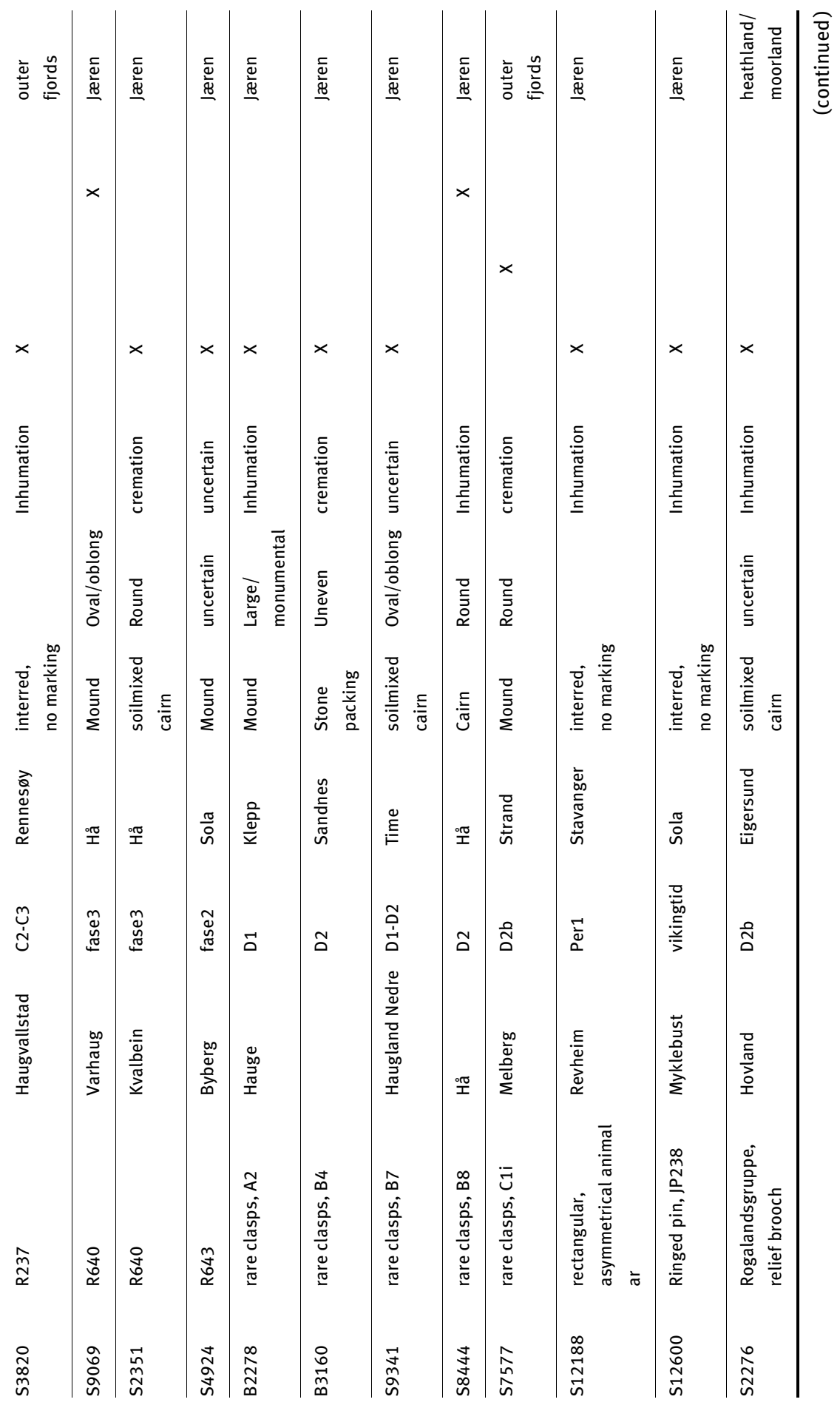




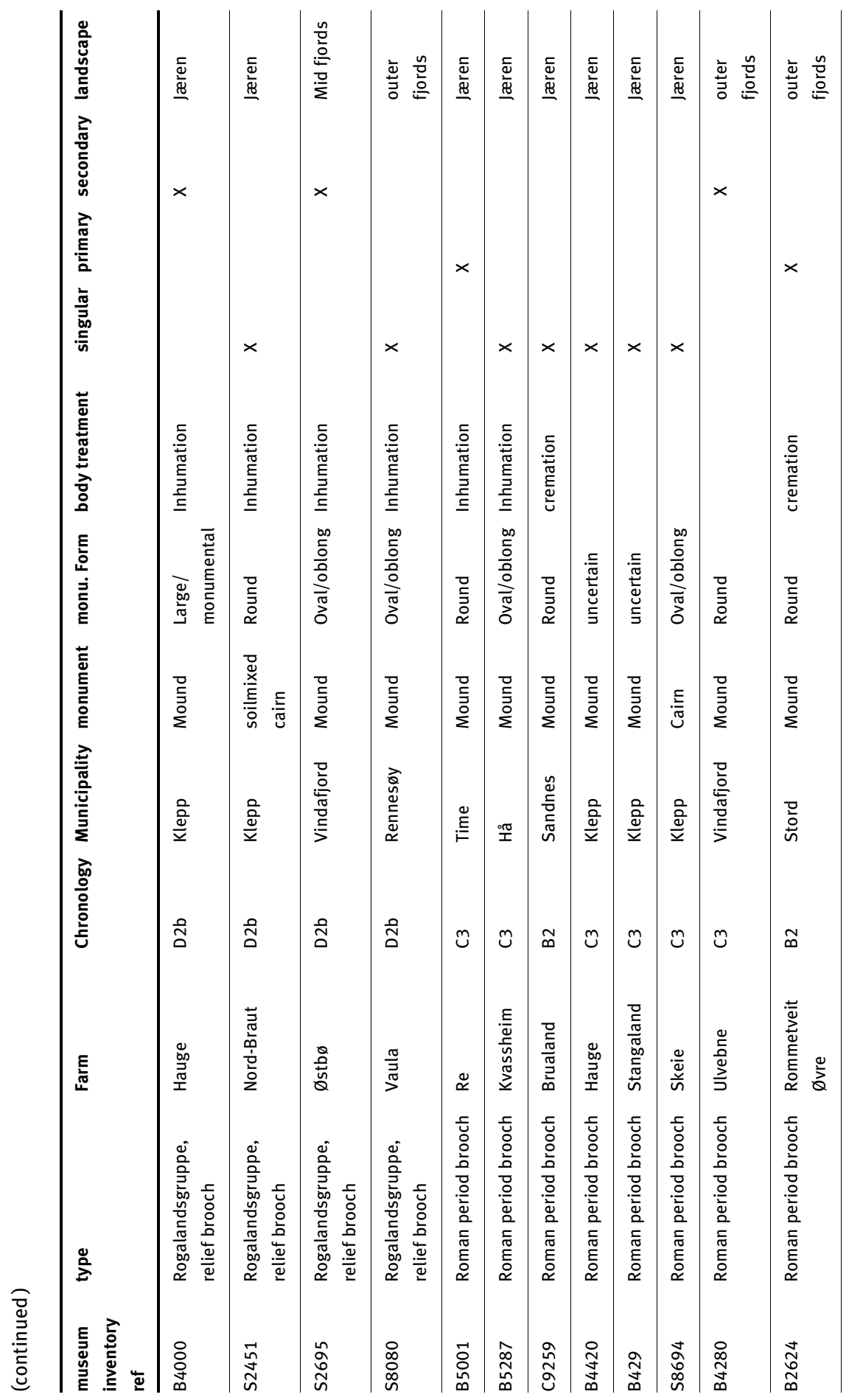




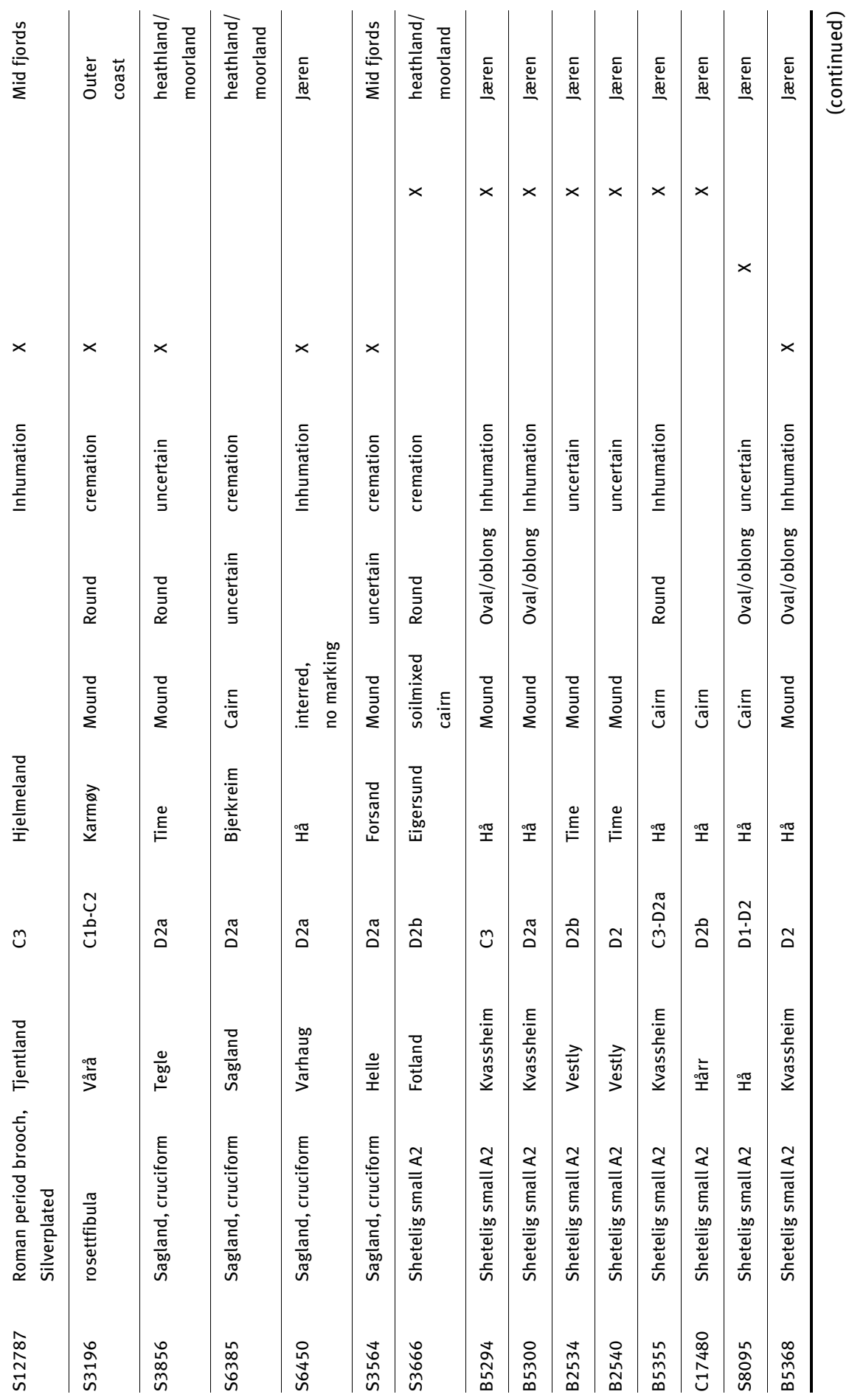




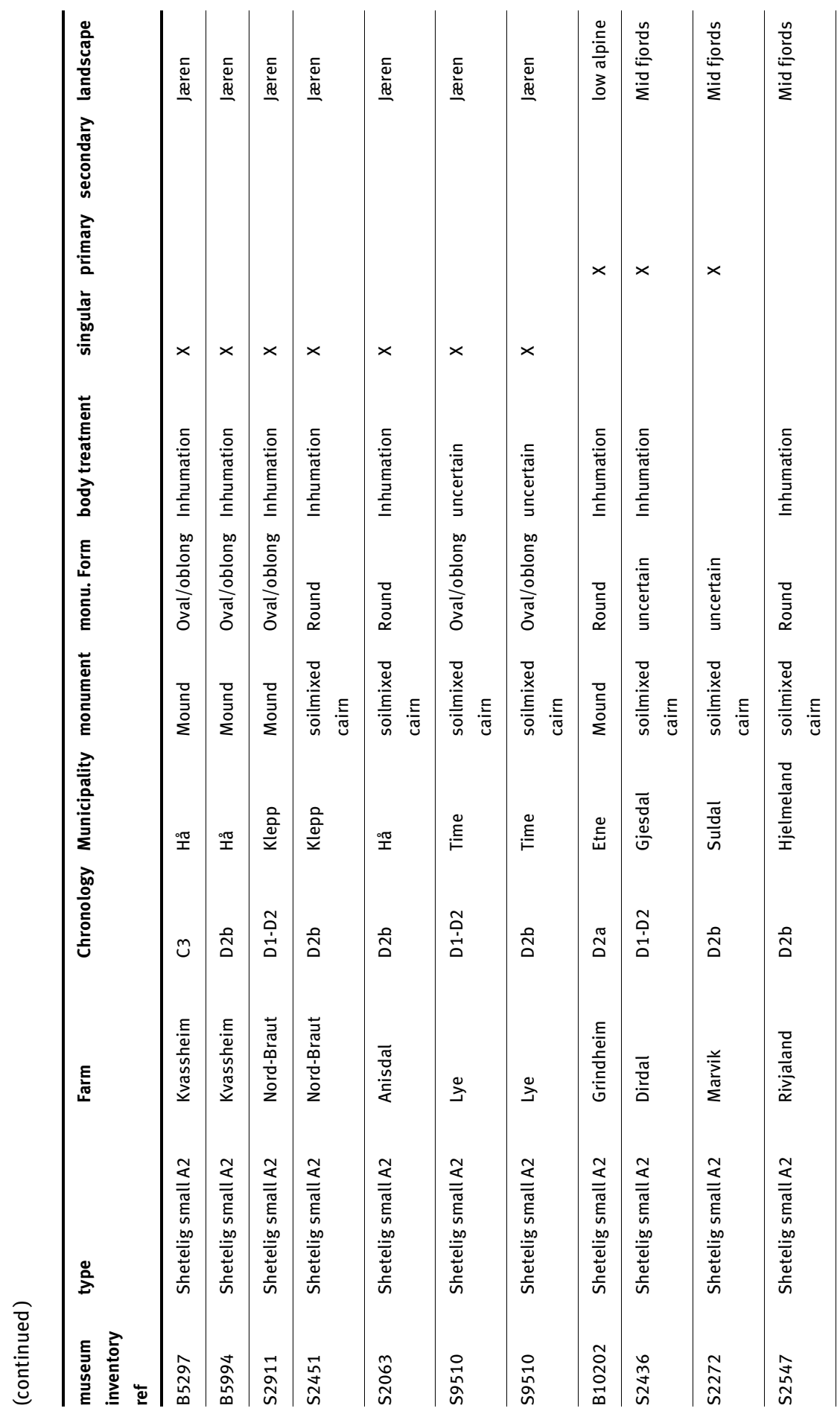




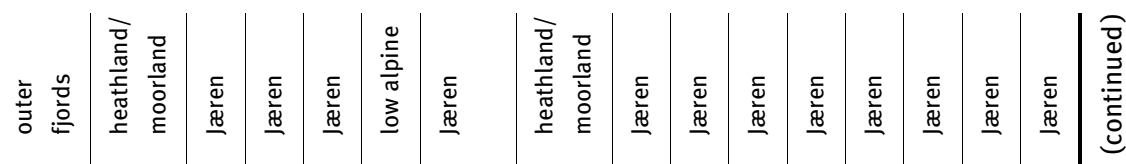

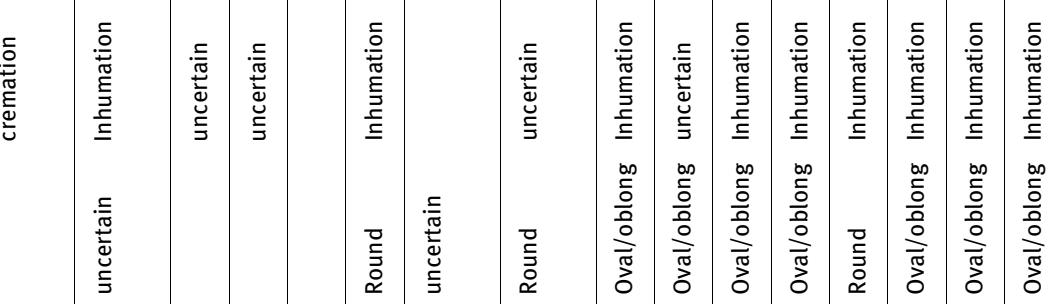

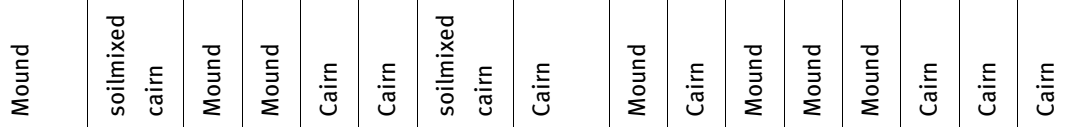

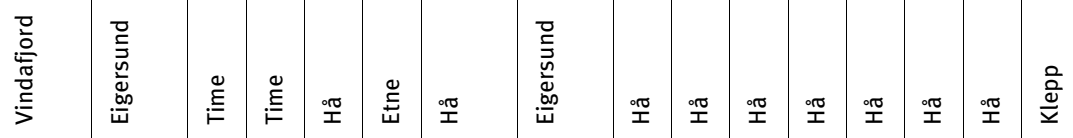

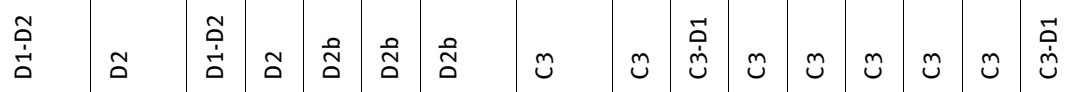

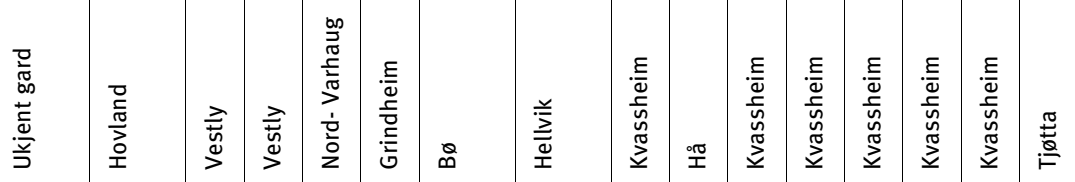

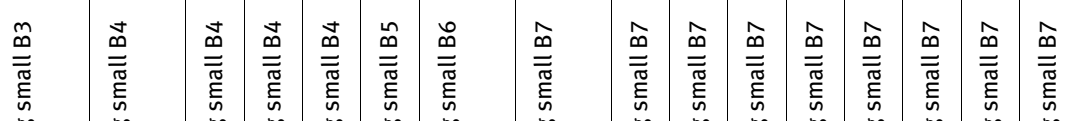

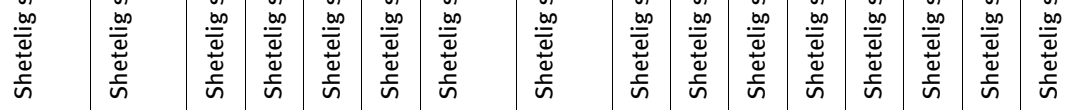

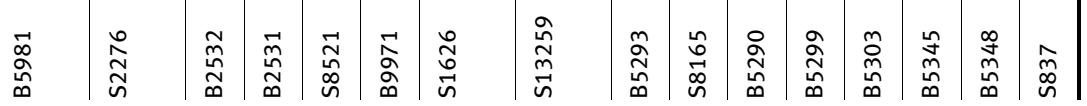




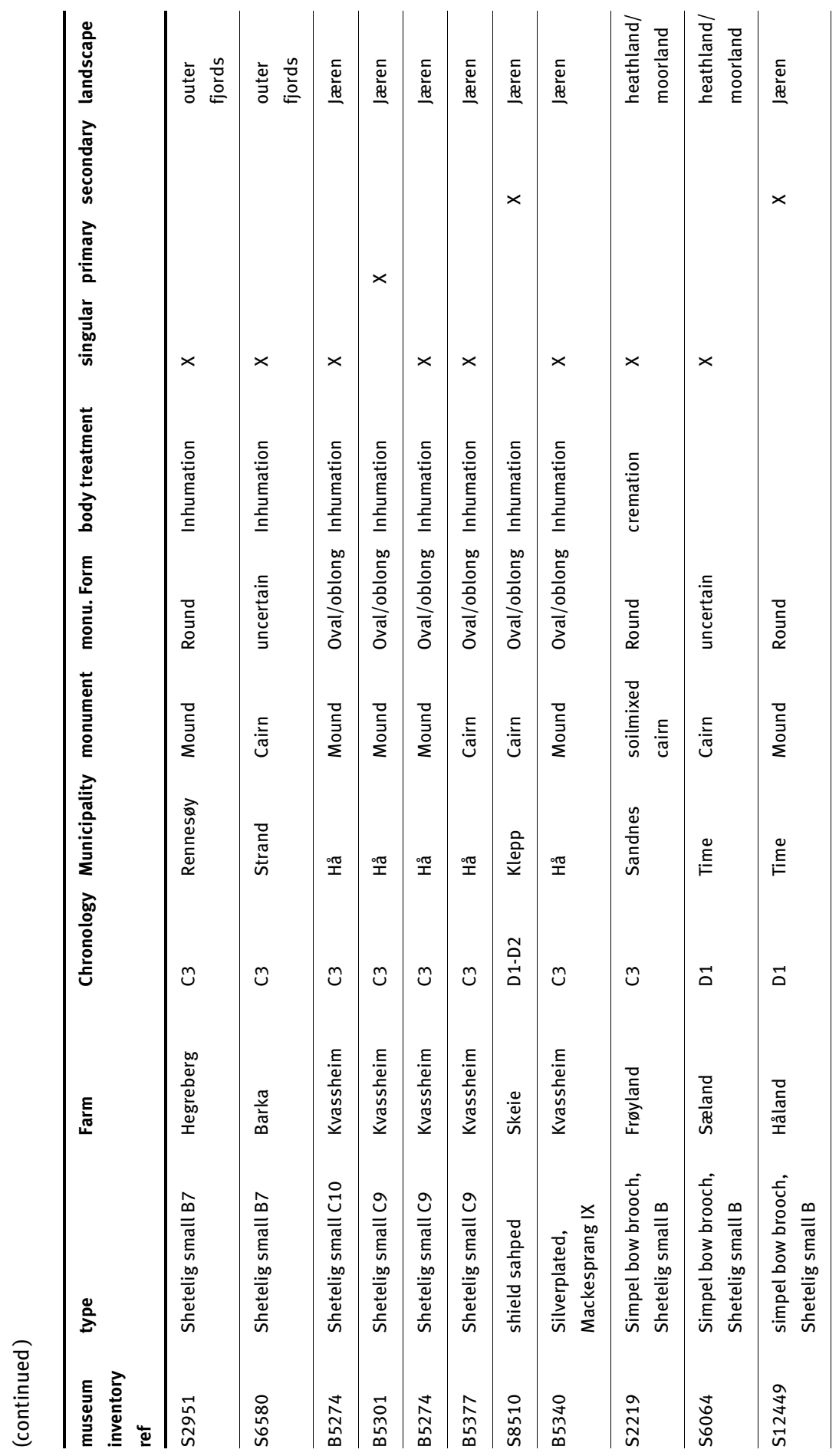




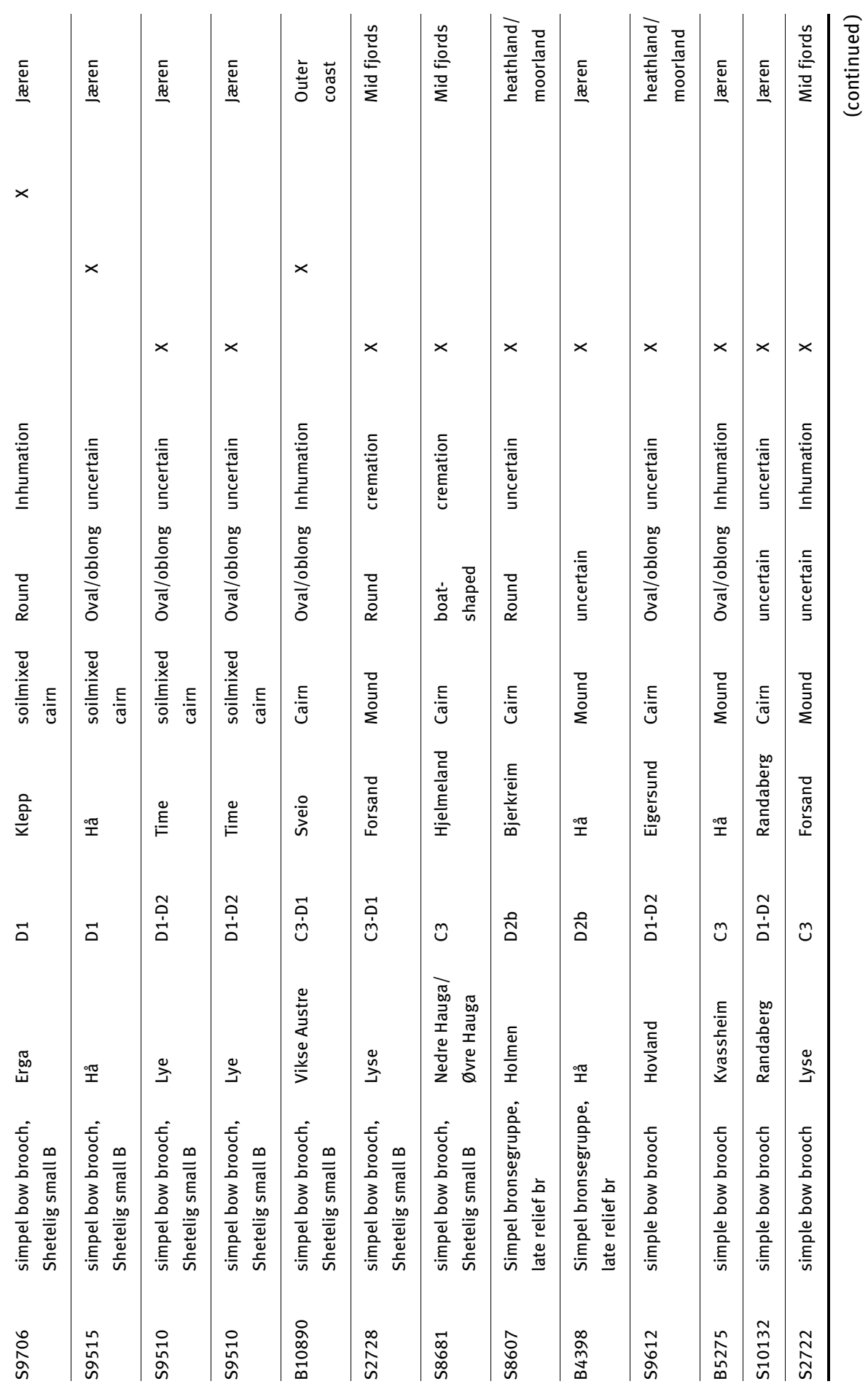




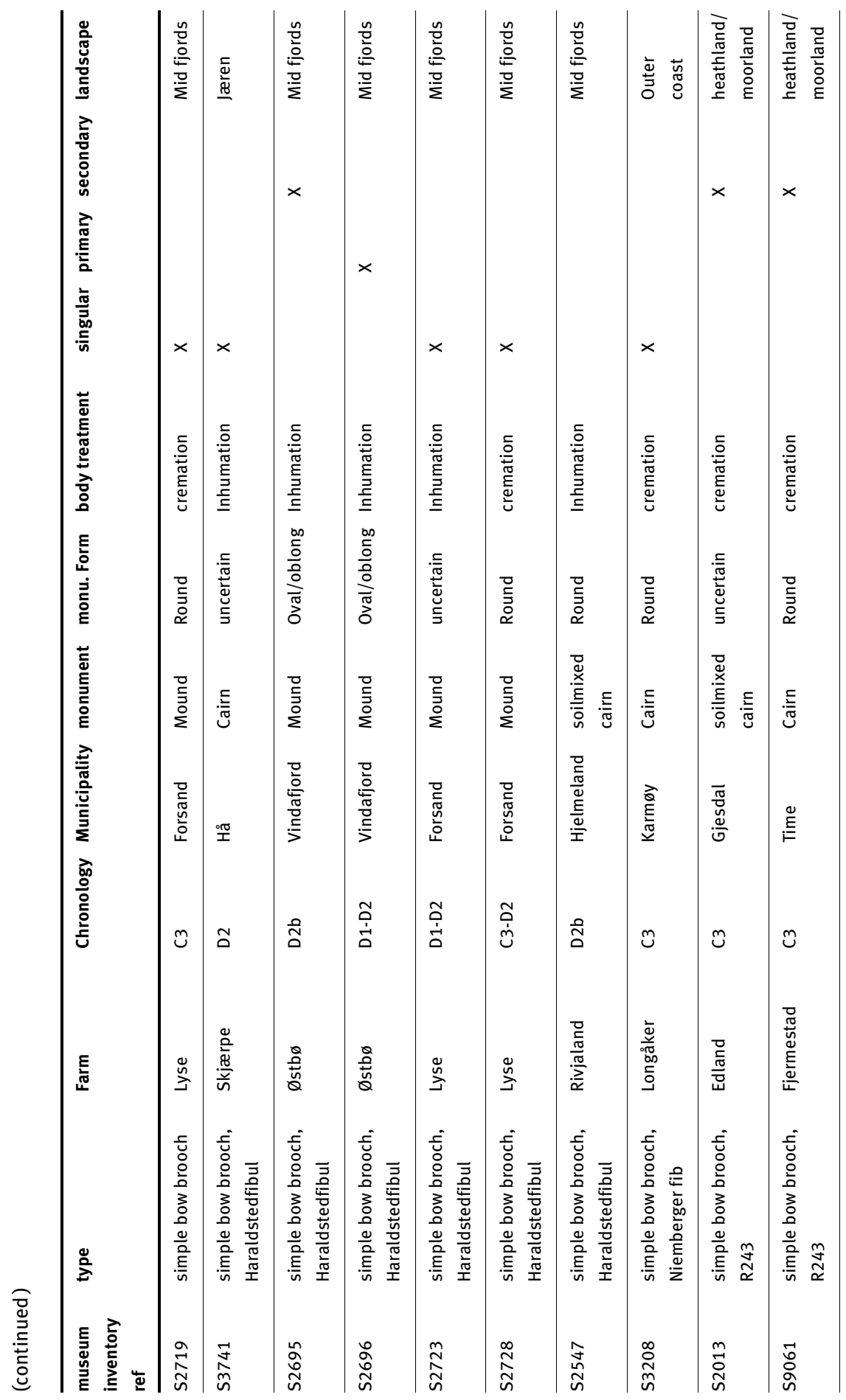




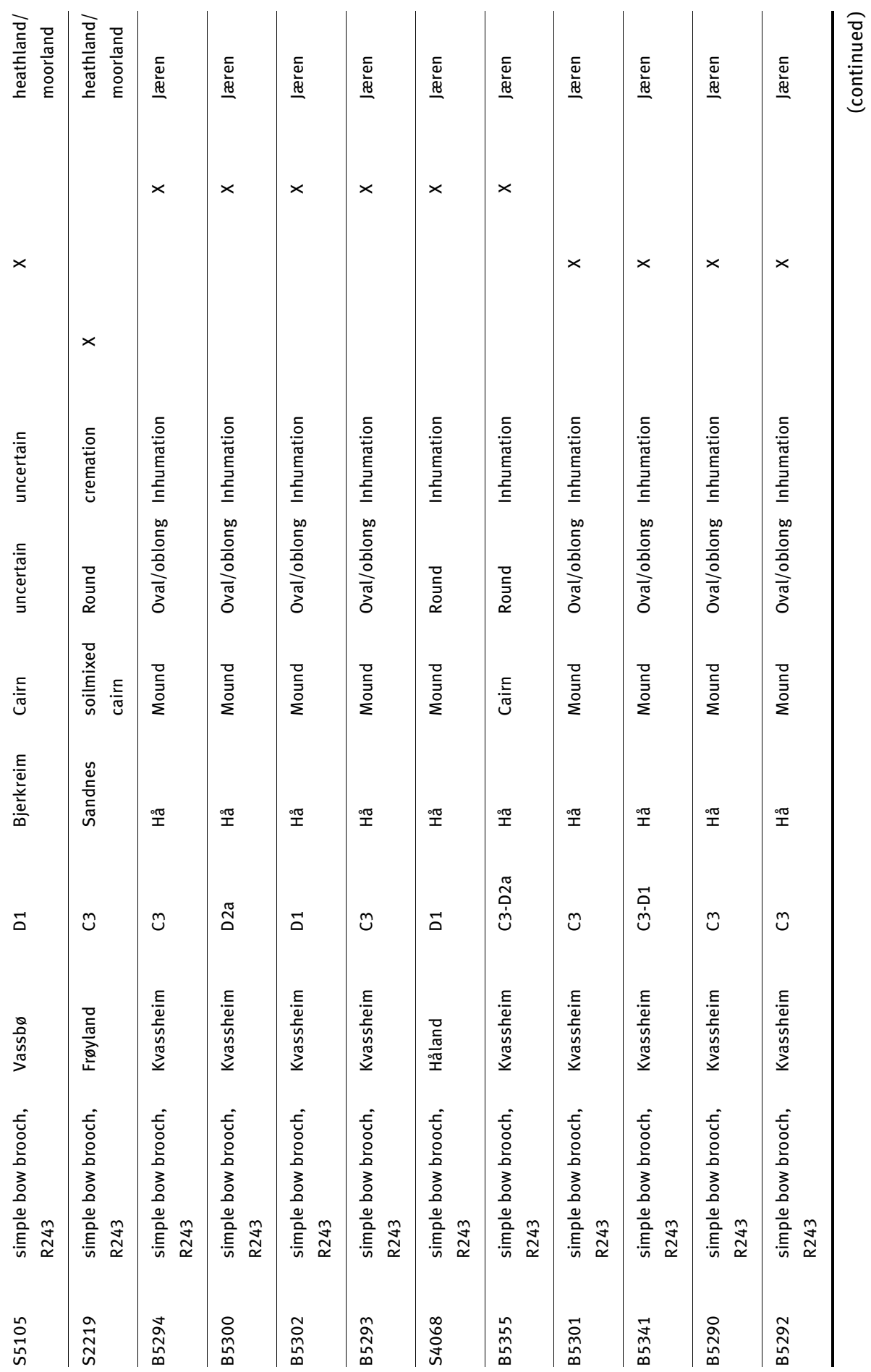




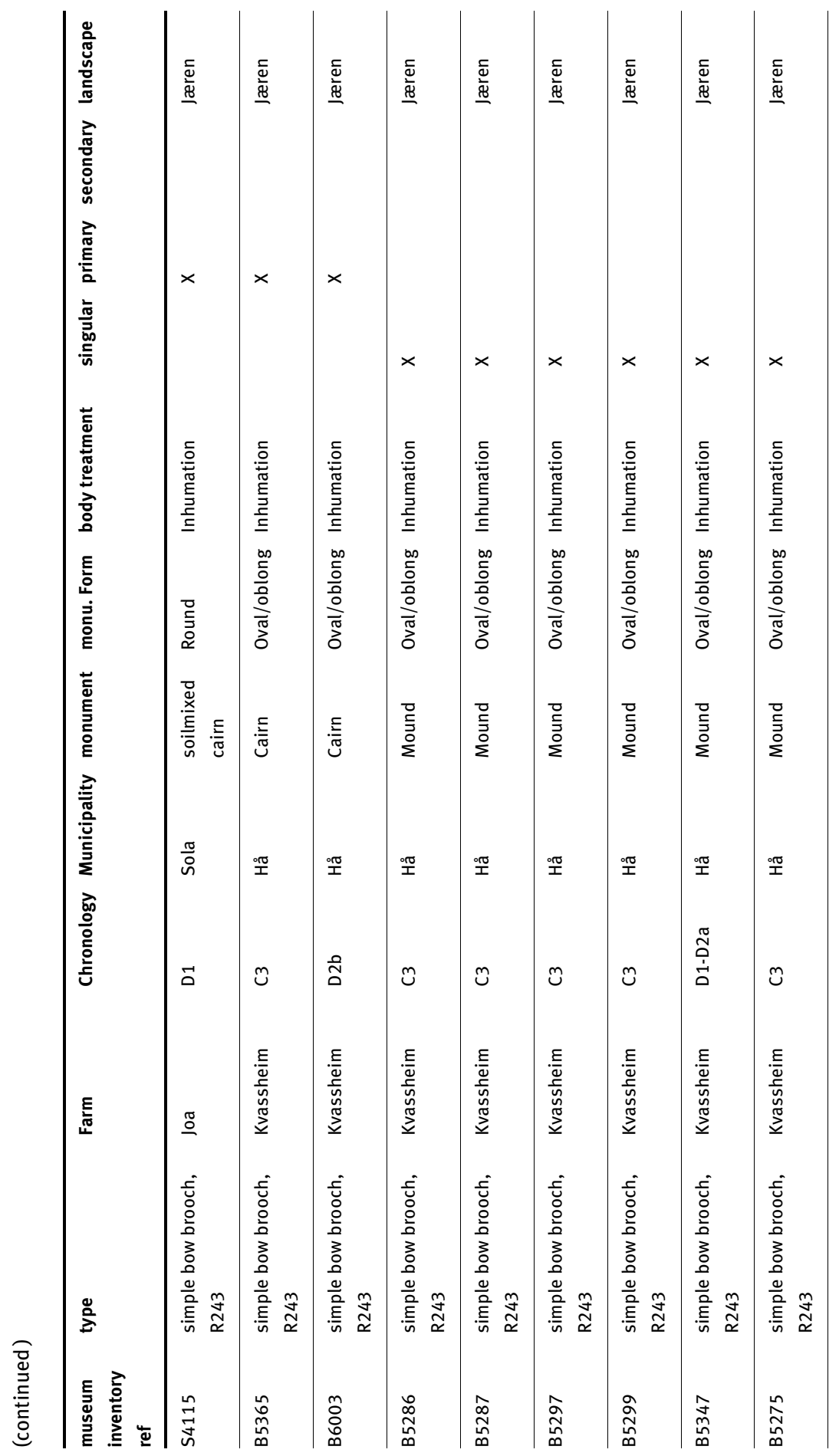




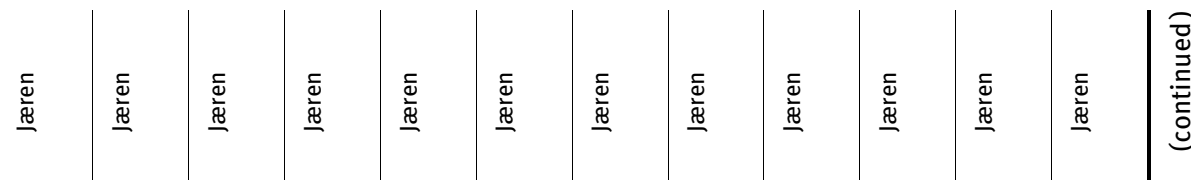

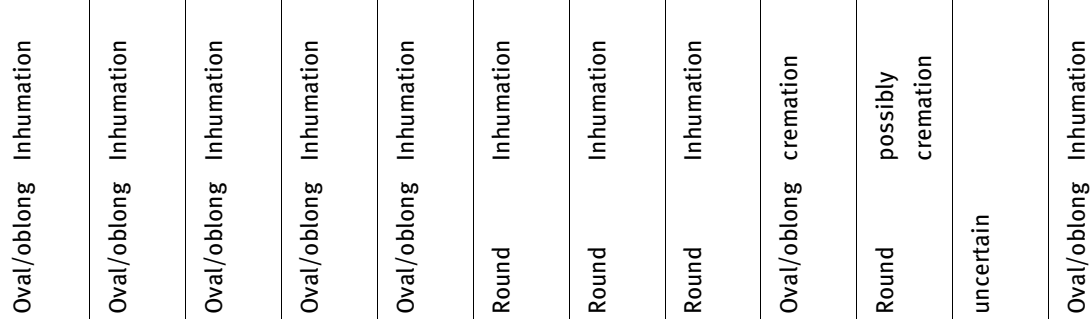

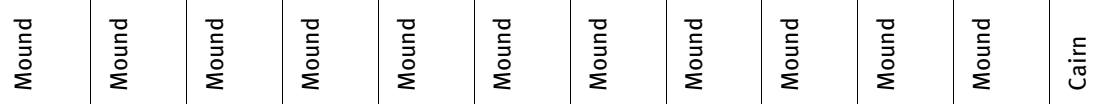

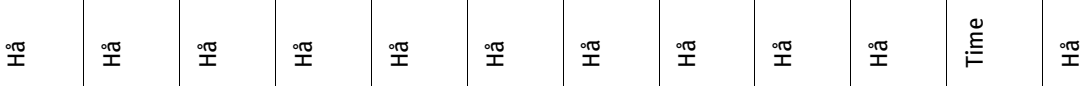

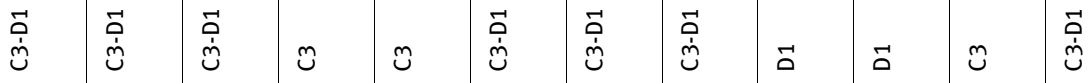

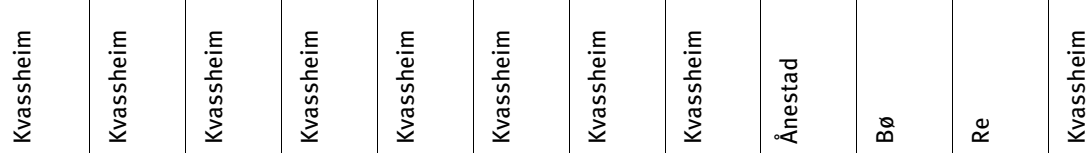

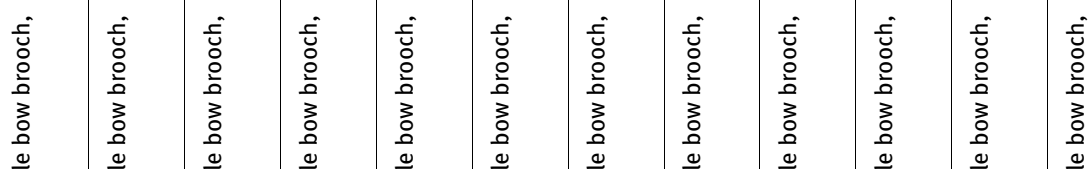

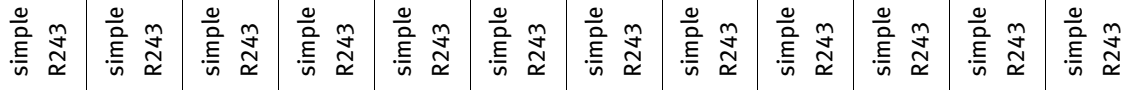

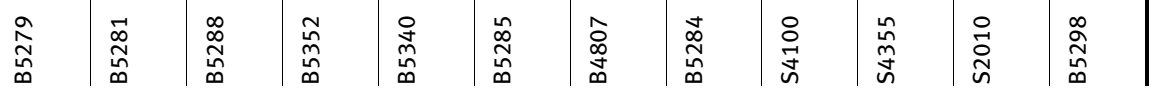




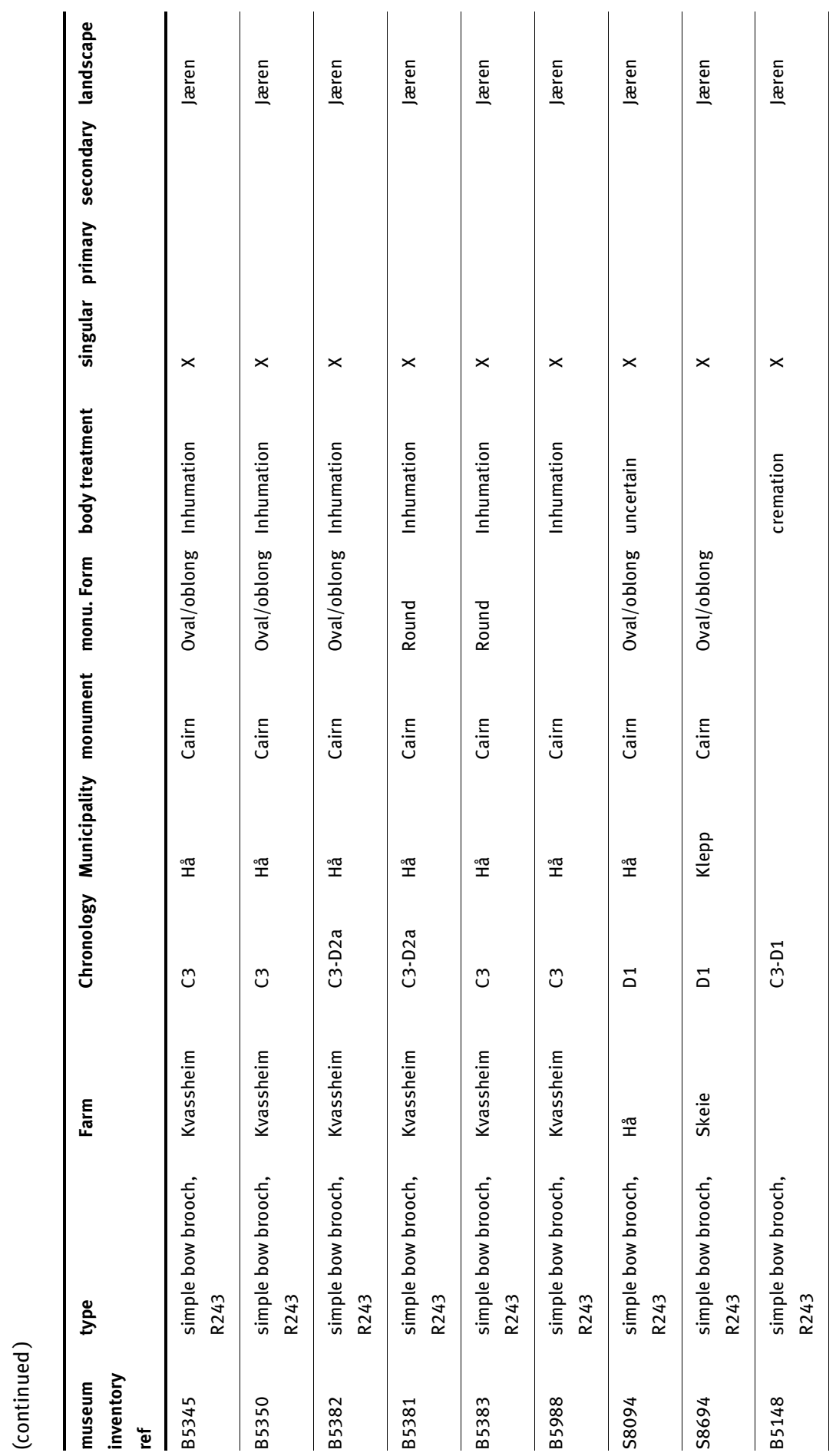




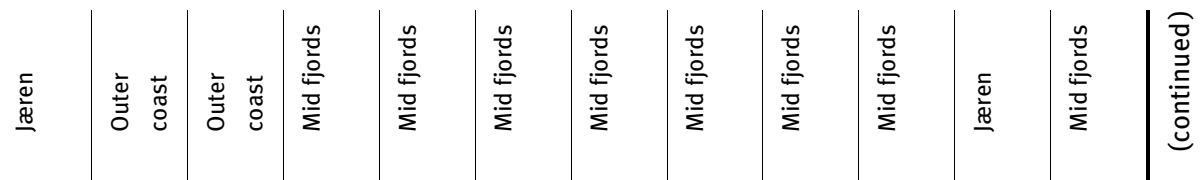

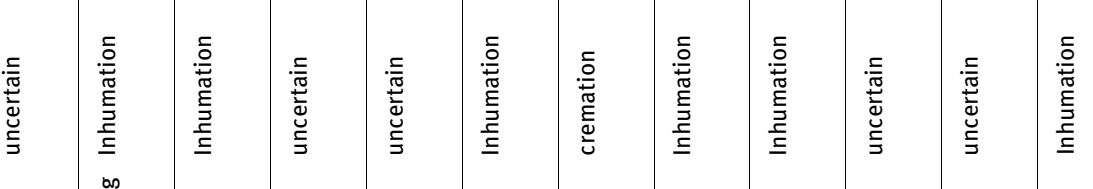

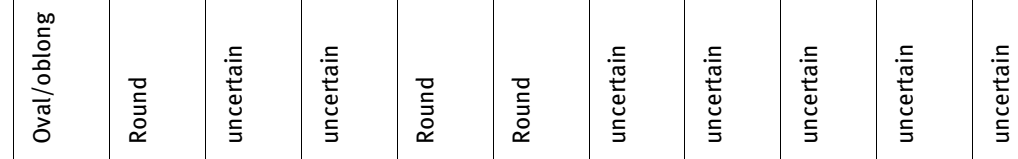

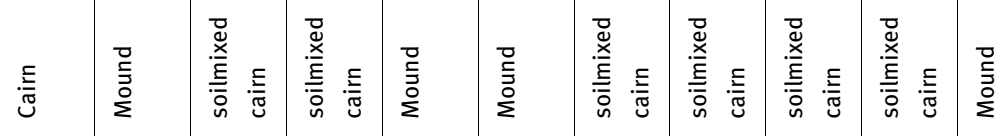

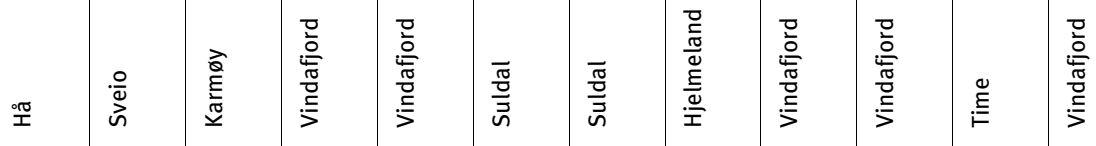

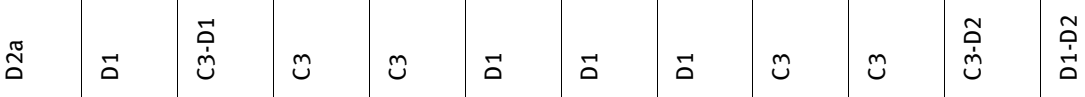

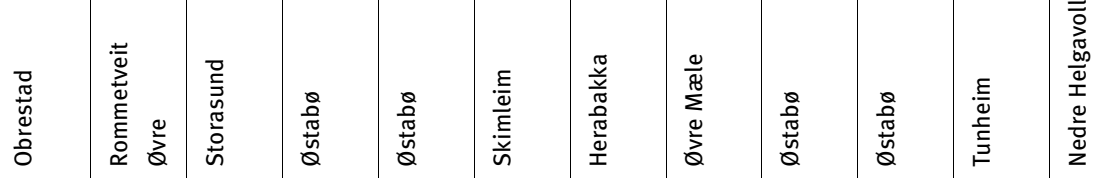

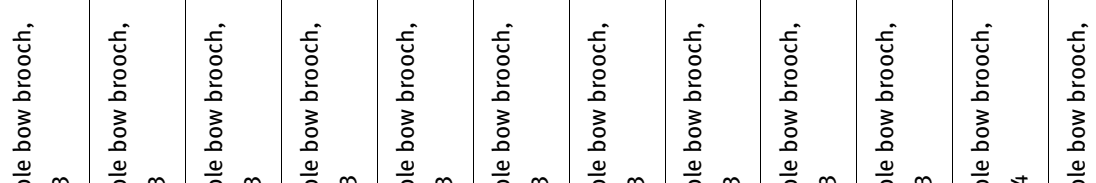

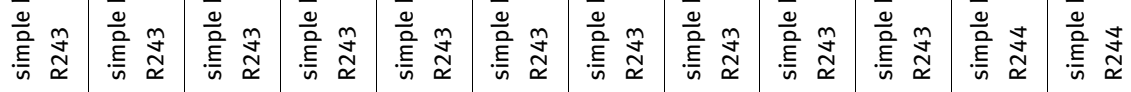

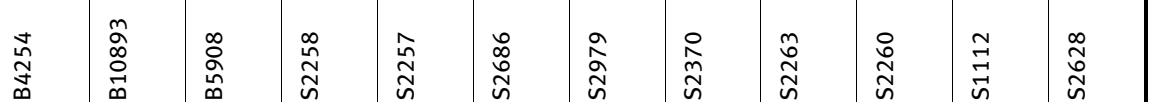




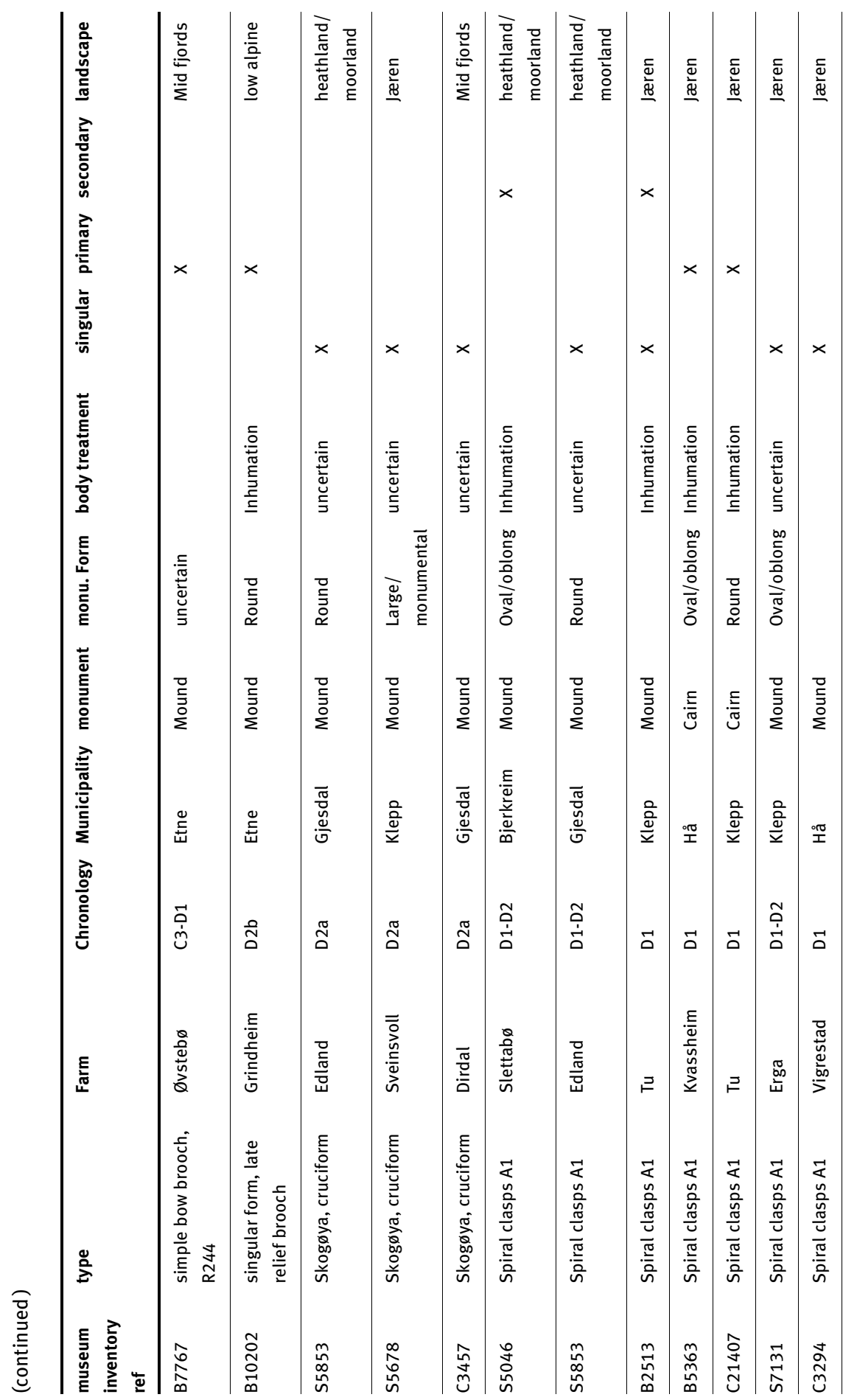




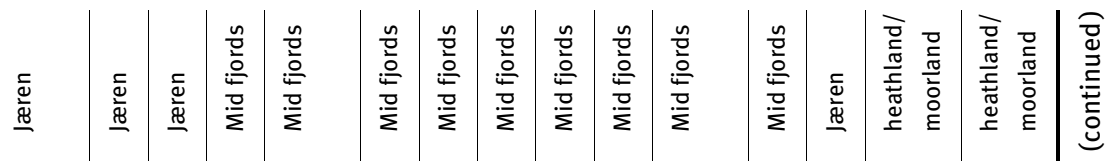

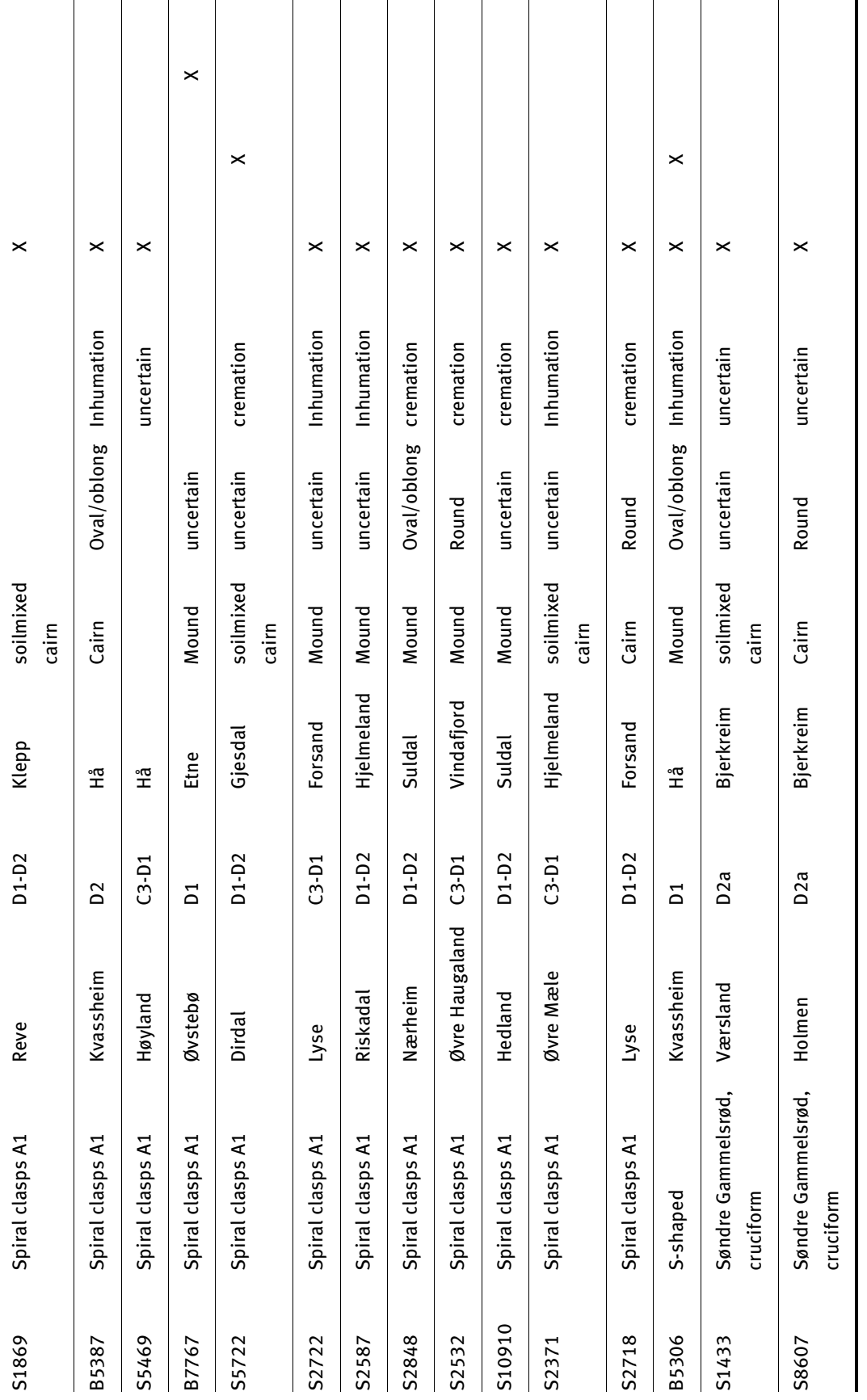




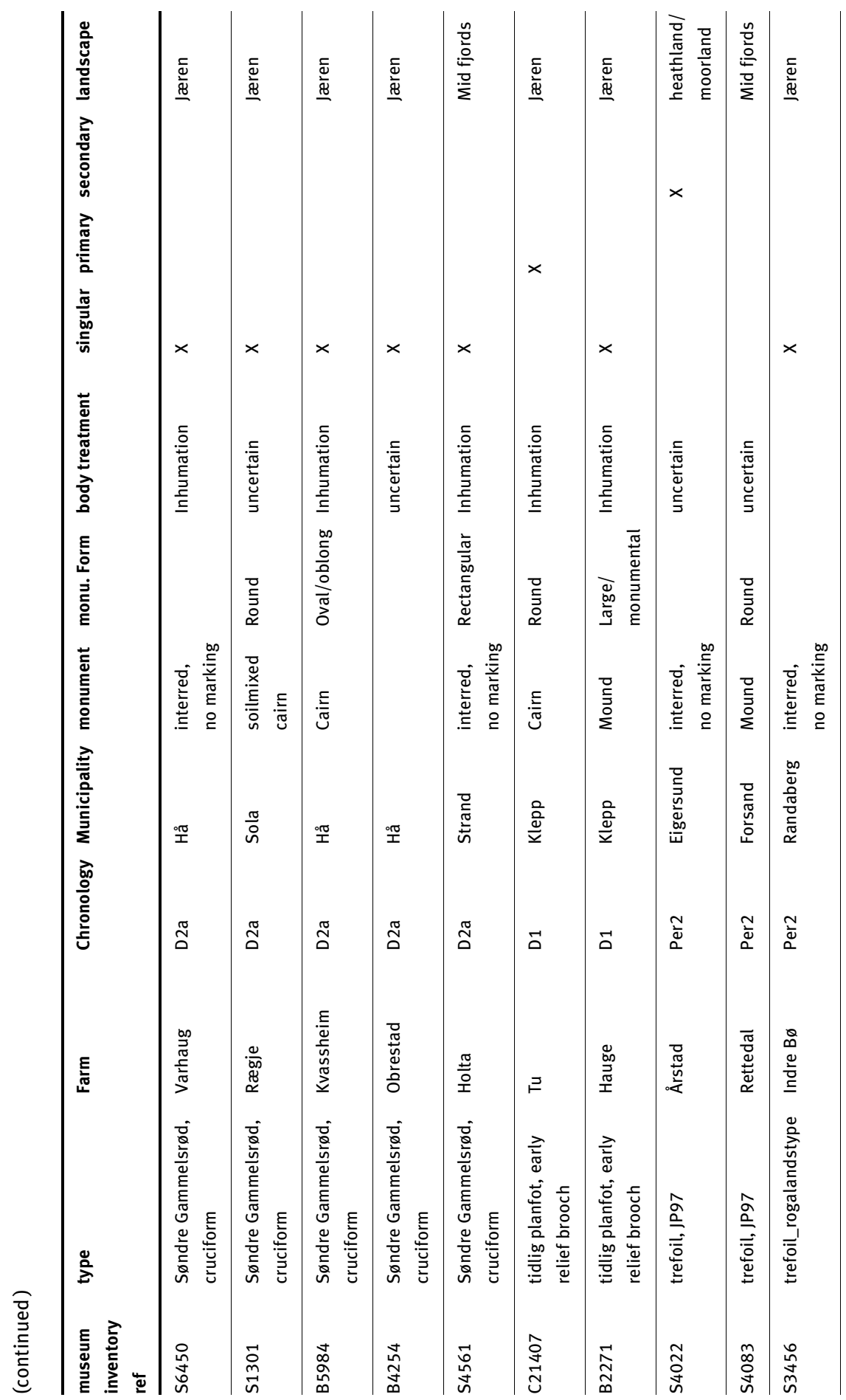




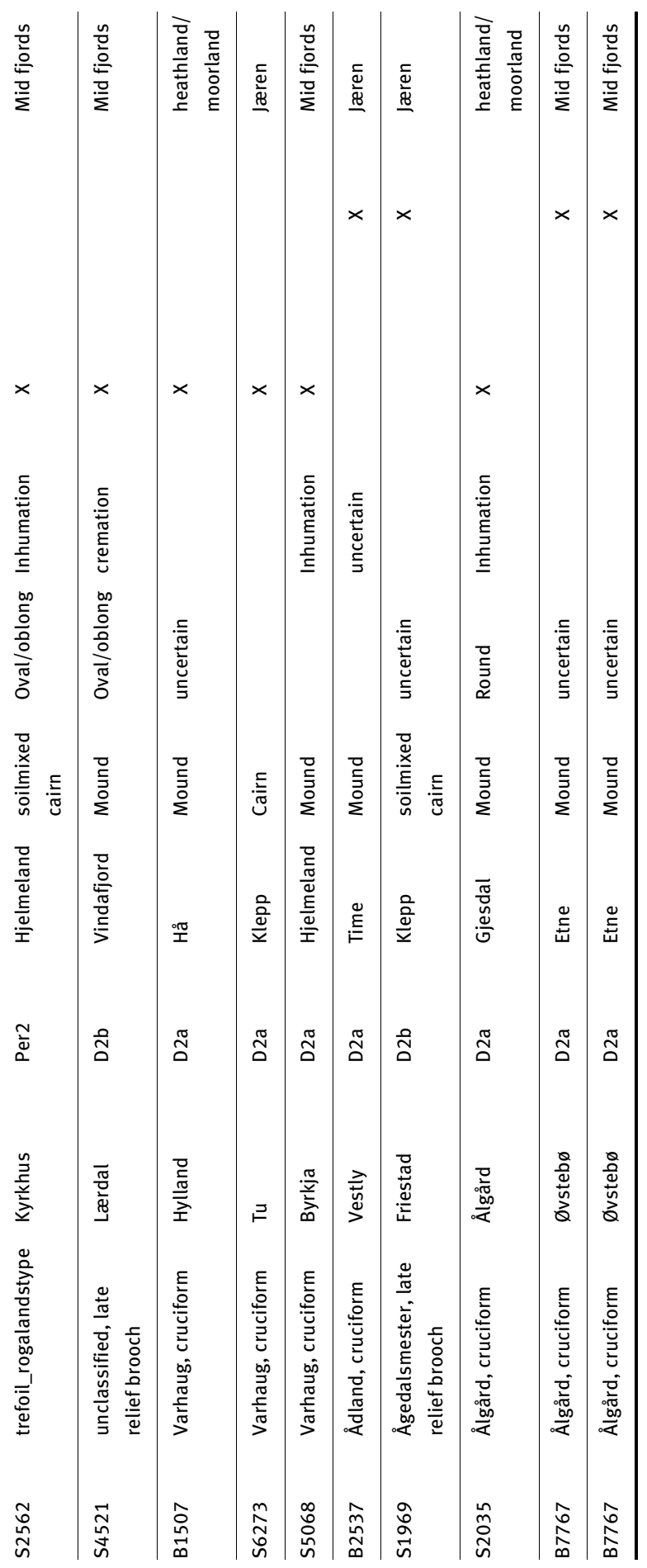


